\title{
Middle Byzantine Ceramics from Southwestern Paphlagonia
}

\section{Ergün Laflı and Gülseren Kan Sahin}

\section{Q OpenEdition \\ 1 Journals}

\section{Electronic version}

URL: http://journals.openedition.org/anatoliaantiqua/347

DOI: 10.4000/anatoliaantiqua.347

\section{Publisher}

IFEA

\section{Printed version}

Date of publication: 1 June 2015

Number of pages: $63-149$

ISBN: 9782362450600

ISSN: 1018-1946

\section{Electronic reference}

Ergün Laflı and Gülseren Kan Sahin, « Middle Byzantine Ceramics from Southwestern Paphlagonia », Anatolia Antiqua [Online], XXIII | 2015, Online since 30 June 2018, connection on 18 December 2020. URL : http://journals.openedition.org/anatoliaantiqua/347 ; DOI : https://doi.org/10.4000/ anatoliaantiqua.347 


\title{
ANATOLIA ANTIQUA ESKI ANADOLU
}

\author{
XXIII
}

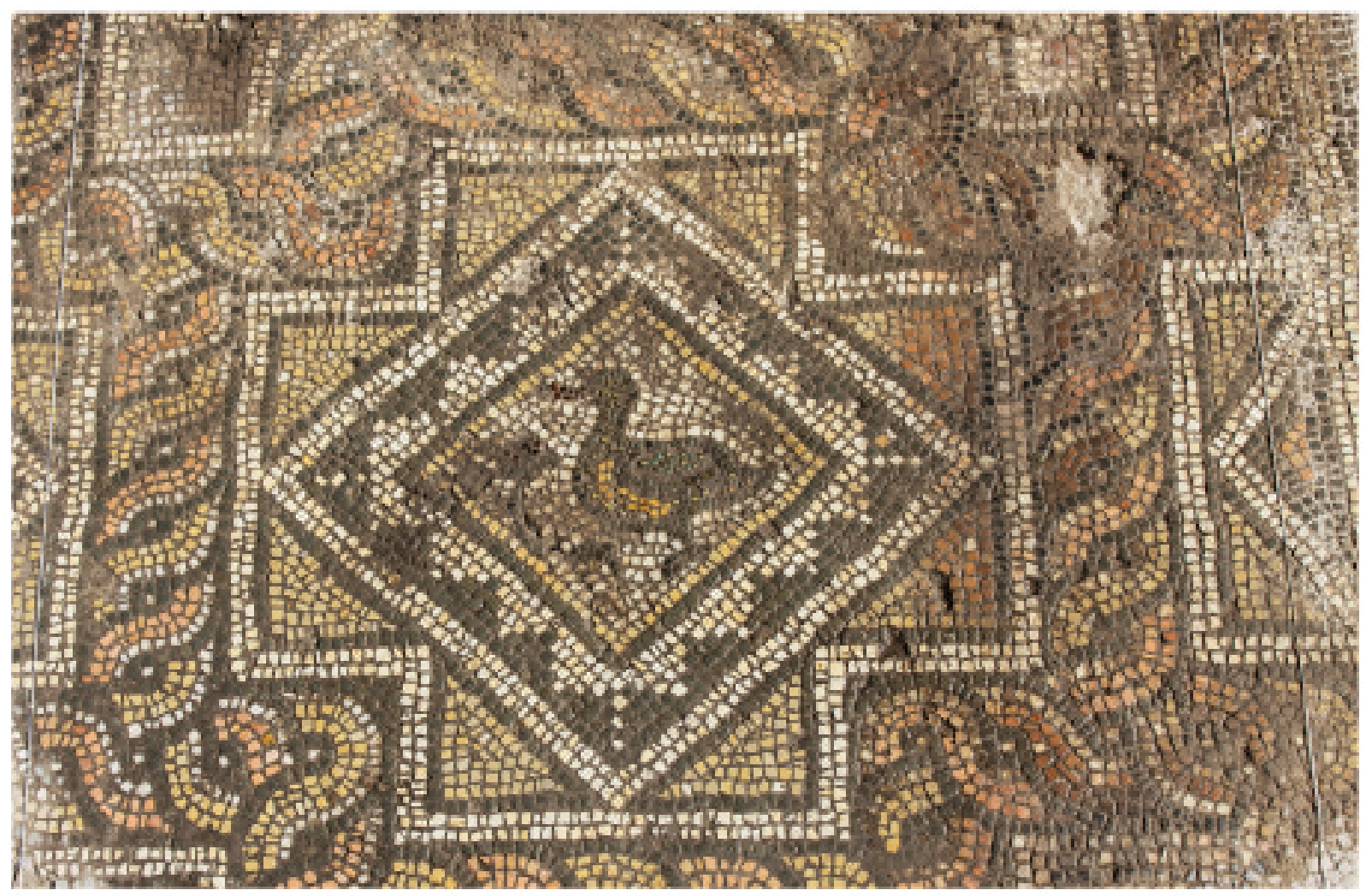

INSTITUT FRANC̣AIS D'ETUDES ANATOLIENNES GEORGES-DUMEZIL CNRS USR 3131 


\section{TABLE DES MATIERES}

Hélène BOUILLON,

On the anatolian origins of some Late Bronze egyptian vessel forms

Agneta FRECCERO,

Marble trade in Antiquity. Looking at Labraunda

Şehnaz ERASLAN,

Dionysus and Ariadne in the light of Antiocheia and Zeugma Mosaics

Ergün LAFLI et Gülseren KAN ŞAHIN,

Middle Byzantine ceramics from Southwestern Paphlagonia

Mustafa AKASLAN, Doğan DEMIRCİ et Özgür PERÇİN en collaboration avec Guy LABARRE, L'église paléochrétienne de Bindeos (Pisidie)

Anaïs LAMESA,

La chapelle des Donateurs à Soğanlı, nouvelle fondation de la famille des Sképidès

Martine ASSENAT et Antoine PEREZ,

Localisation et chronologie des moulins hydrauliques d'Amida. A propos d'Ammien Marcellin,

XVIII, 8,11

Helke KAMMERER-GROTHAUS,

$»$ Ubi Troia fuit«

Atzik-Köy - Eine Theorie von Heinrich Nikolaus Ulrichs (1843)

CHRONIQUES DES TRAVAUX ARCHEOLOGIQUES EN TURQUIE, 2015

Sami PATACI et Ergün LAFLI,

Surveys in Ardahan on the turkish-georgian borderline in 2013 and 2014

Çĭ̆dem MANER,

Preliminary report on the second season of the Konya-Ereğli survey (KEYAR) 2014

Dominique BEYER, Can KARAVUL, Françoise LAROCHE-TRAUNECKER et Aksel TiBBET,

Rapport préliminaire sur les travaux de la mission archéologique de Zeyve Höyük-Porsuk 2014

Jean-Charles MORETTI avec la collaboration de Nicolas BRESCH, Isabel BONORA,

Jean-Jacques MALMARY et Olivier RISS,

Claros, le temple d'Apollon : travaux réalisés en 2014

Olivier HENRY et Erika ANDERSSON, Christophe BOST, Ömür Dünya ÇAKMAKLI, Angela COMMITO, Mélissa CORMIER-HUGUET, Peter DE STAEBLER, Pierre DUPONT, Duygu ERGENÇ, Axel FREJMAN, Banu KEPENEK, Pascal LEBOUTEILLER, Haral NILSSON, Felipe ROJAS, Baptiste VERGNAUD, 


\section{MIDDLE BYZANTINE CERAMICS FROM SOUTHWESTERN PAPHLAGONIA}

Southwestern Paphlagonia locates in the region around Hadrianoupolis and its chora, today's Eskipazar in the Province of Karabük. Ceramic reports of Iron Age, Hellenistic, Roman and Late Roman/Early Byzantine periods as well as unguentaria and lamps from southwestern Paphlagonia are already appeared in the previous issues of Anatolia Antiqua ${ }^{1}$ as well as elsewhere ${ }^{2}$ that are featuring the surface and excavated finds from the field seasons between 2005 and 2008 by a team of Dokuz Eylül University (DEU). This current report is the last one in this series and focuses on the Middle Byzantine period.

Paphlagonia is the name of the province on the north-central Black Sea coastline of Asia Minor, situated between Bithynia and Pontus. Paphlagonia was a major source of timber during and after the Roman period, as it was rich in forestry ${ }^{3}$. It appeared as a separate province in the $4^{\text {th }}$ cent. A.D. ${ }^{4}$ (Map 1). Political geography of Paphlagonia during the Early Byzantine period is well known through the $\Sigma v v \varepsilon ́ \kappa \delta \eta \mu o \varsigma$ of Hierocles, as the Roman towns of Inner Paphlagonia survived since $2^{\text {nd }}$ cent. into the $6^{\text {th }}$ cent. A.D. and some new sites were added in $6^{\text {th }}$ cent. A.D. ${ }^{5}$. In $7^{\text {th }}$ cent. Paphlagonia became part of the theme of Obsequium (or Opsikion) and, later, of the Bucellarian theme, before it was split off again to form a separate unit. A fundamental shift in the civic life of cities, changing the urban life across the entire region into the $7^{\text {th }}$ cent. A.D. and beyond were occured ${ }^{6}$. In this period Paphlagonia became a theme, i.e. a military-civilian province of the Byzantine Empire. The territory of the theme Paphlagonia was corresponding roughly to the Late Antique province of Paphlagonia, which had been subsumed in the themes of Obsequium and Bucellarian 7 . Its governing

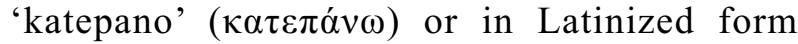
'capetanus/catepan', i.e. a senior Byzantine military rank and office as a captain or fleet commander, was first mentioned in the later A.D. 830s'; but ' $\mathrm{Pa}$ phlagonia' was definitely created after $\mathrm{ca}$. $815-819^{9}$ and so the theme seems to have been established during the reigns of Leo V the Armenian (A.D. 813820) or Michael II (A.D. 820-829), simultaneously with the theme of Chaldea in $c a .820^{10}$. After the battle of Manzikert in A.D. 1071 and the lasting entry of the Seljuk Turks into Asia Minor most of Paphlagonia was lost to the Seljuk Turks; Alexius I Comnenus (A.D. 1081-118) recovered the Paphlagonian coast. But the campaigns of John II Comnenus (A.D. 1118-1143) in 1130 s destined to reconquer the interior were in vain. After the Fourth Crusade in A.D. 1202-1204 the Paphlagonian coast came under the control of David Comnenus (A.D. $c a$. 1184-1212), but in A.D. 1214 the Nicaean emperor

*) Dokuz Eylül Üniversitesi, Edebiyat Fakültesi, Arkeoloji Bölümü, Tınaztepe/Kaynaklar Yerleşkesi, Buca, TR-35160 Izmir, Turkey; <elafli@yahoo.ca>; <gulserenkan@hotmail.com>.

1) Laflı and Kan Şahin 2012 and 2014; as well as Lafl, Kan Şahin and Patac1 2013.

2) Laflı and Kan Şahin 2013, 2014; as well as Kan Şahin and Laflı 2015.

3) Anderson 2011: 38; Wilson 1960: 37; and Broughton 1938: 616-617.

4) Belke 1996: 65: The name 'Paphlagonia' appears as one of the seven provinces of 'Pontica' in so-called 'Laterculus Veronensis' or the Verona List, a list of Roman provinces from the times of the Roman emperors Diocletian and Constantine I at A.D. $314 / 315$.

5) Honigmann 1939: Nov. 28, 29 and 31; as well as Jones 1971: 171.

6) Mitchell 1993: 120-121; Matthews, Metcalfe and Cottica 2009: 191; as well as for Middle Byzantine towns: Brandes 1989: 3839 and $71-88$.

7) Belke 1996: 69-74; Kazhdan 1991: 1579; Pertusi 1952: 136; as well as Brooks 1901: 69, 71, 73 and 76-77.

8) Belke 1996: 74 and 137; Constantine VII Porphyrogenitus, De administrando imperio (eds. Moravcsik and Jenkins 1985): 182; as well as Theophanes Continuatus (ed. Bekker 1838): 122-123.

9) Theodore the Studite, Epistulae (ed. Fatouros 1992): 2 and 63; Treadgold 1988/1989: 140-143; and Belke 1996: $73 \mathrm{f}$. Leo V the Armenian was killed on A.D. December 25, 820; after him Michael II became the emperor.

10) McGeer, Nesbitt and Oikonomides 2001: 25; Oikonomides 1972: 349; Brüggemann 2012: 49; Winkelmann 1985: 110-111; and Lounghis 1998: 53. 


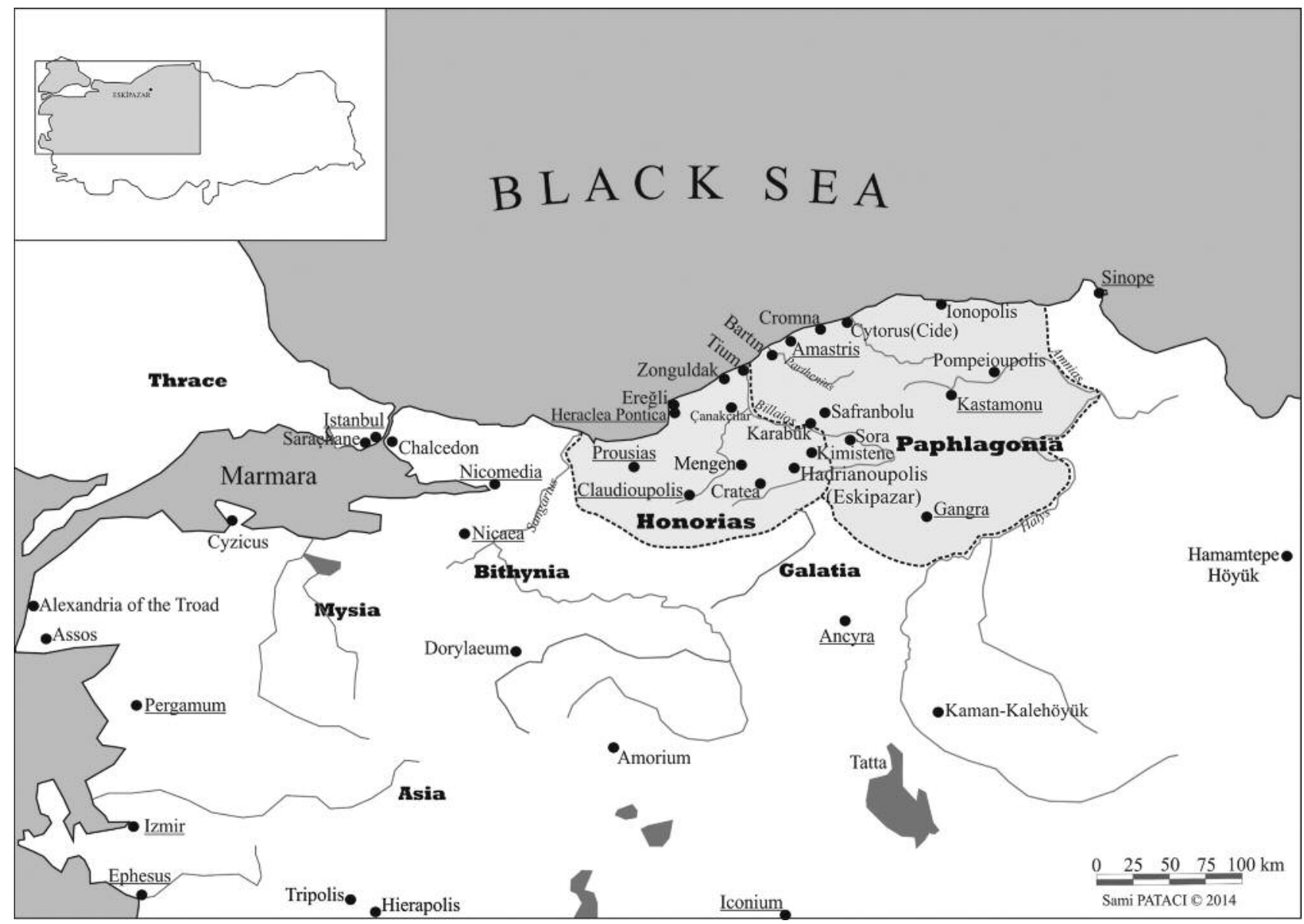

Map 1: Map of Byzantine Paphlagonia, Northern and Central Anatolia with the quoted places in the text. Underlined places indicate cities with local museums.

Theodore I Lascaris (A.D. 1205-1222) seized the western parts up to Cromna, ca. $45 \mathrm{~km}$ east of Amastris. These remained in Byzantine hands until the late $14^{\text {th }}$ century, when they were taken over by the Turks or the Genoese.

In late $5^{\text {th }}$-early $6^{\text {th }}$ cent. A.D. there was a sudden population and urban boom in Hadrianoupolis (Map 3) and its chora (Map 2) whereas the Early Byzantine period of this region was not very well represented in literary and ecclestiastical sources. Although Hadrianoupolis experienced growth and transformation up to the mid of $7^{\text {th }}$ cent., the written sources indicate some Arab invasions to the region in A.D. $720 \mathrm{~s}^{11}$ which caused for the abandonment of the city ${ }^{12}$. After the first quarter of $8^{\text {th }}$ cent. A.D. the emergence of a series of fortified hilltop sites in several parts of Paphlagonia is an archaeological indication of the first Arab attacks to the region which is evidenced through the recent BIAA surveys ${ }^{13}$. These fortified hilltop sites encountered in Inner Paphlagonia were being dated first and foremost to the centuries from A.D. 700, with the first incursion of Arab forces, to around A.D. 1200 with the final absorption of the region into the Turkish world ${ }^{14}$. In our field researches the term 'Middle Byzantine' fits to the period between $\mathrm{mid} / \mathrm{late} 9^{\text {th }}$ cent. to beginning of $12^{\text {th }}$ cent., a long phase with the abandonment of Hadrianopolis, Kimistene's use as a fortified hilltop site by the remaining local Greek speaking Christians and the arrival of Turks in late

11) Ahrweiler 1962: 9 and 28.

12) For the studies which highlight the phenomenon of Late Antique ruralisation in Asia Minor: Baird 2004: 219-246; Foss 1979; Ivison 2007: 25-60; Kirilov 2007: 3-24; Müller-Wiener 1986: 435-475; Niewöhner 2003: 221-228; 2007: 119-158; Ratté 2001: 116147; as well as Vanhaverbeke, Martens and Waelkens 2007: 611-648.

13) Matthews, Metcalfe and Cottica 2009: 190-199, figs. 6.29 and 6.35; as well as Bes 2015: 277.

14) Matthews, Metcalfe and Cottica 2009: 195. 


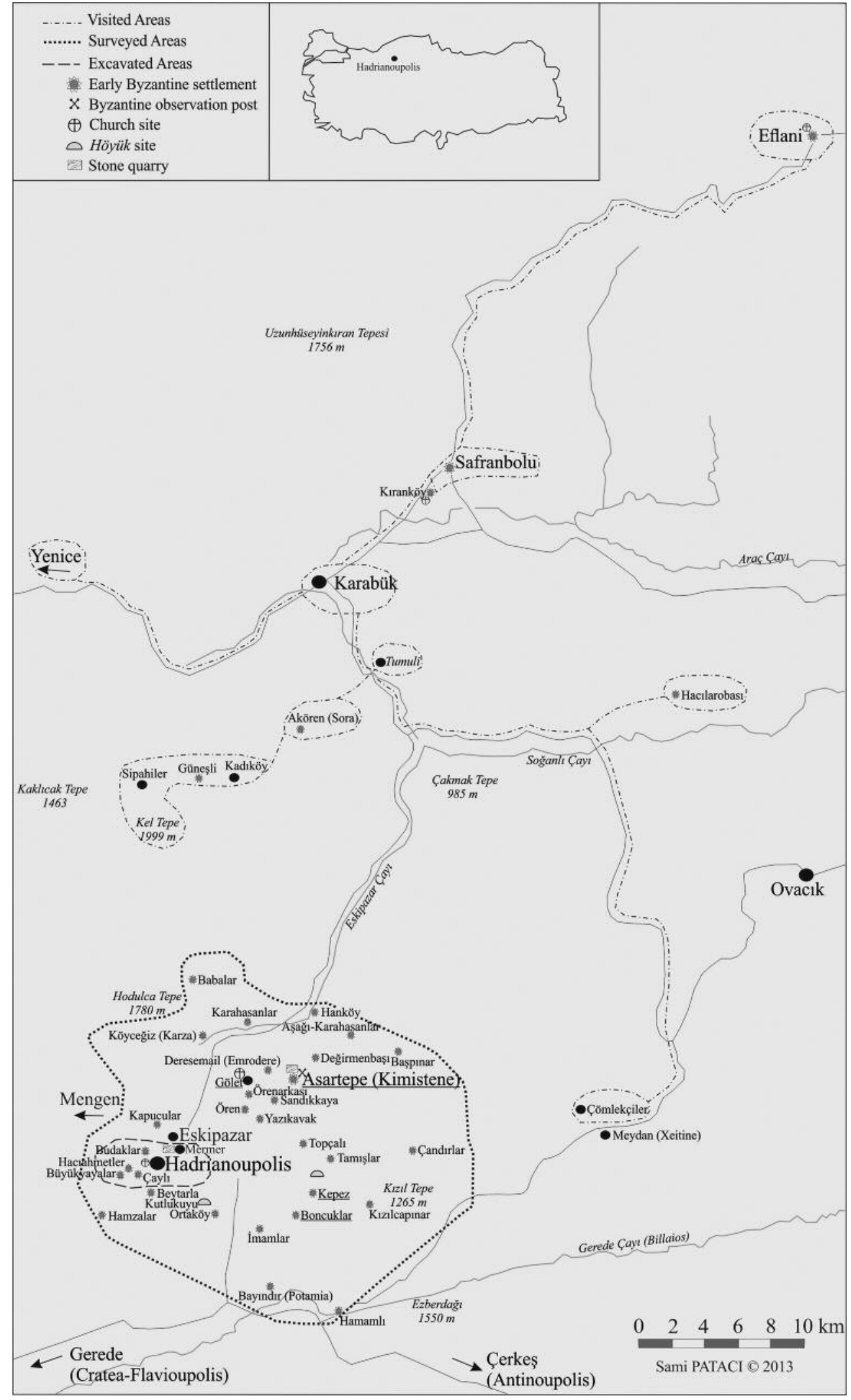

Map 2 : Map of the surveyed areas in southwestern Paphlagonia with locations of Middle Byzantine pottery finds (2008). 


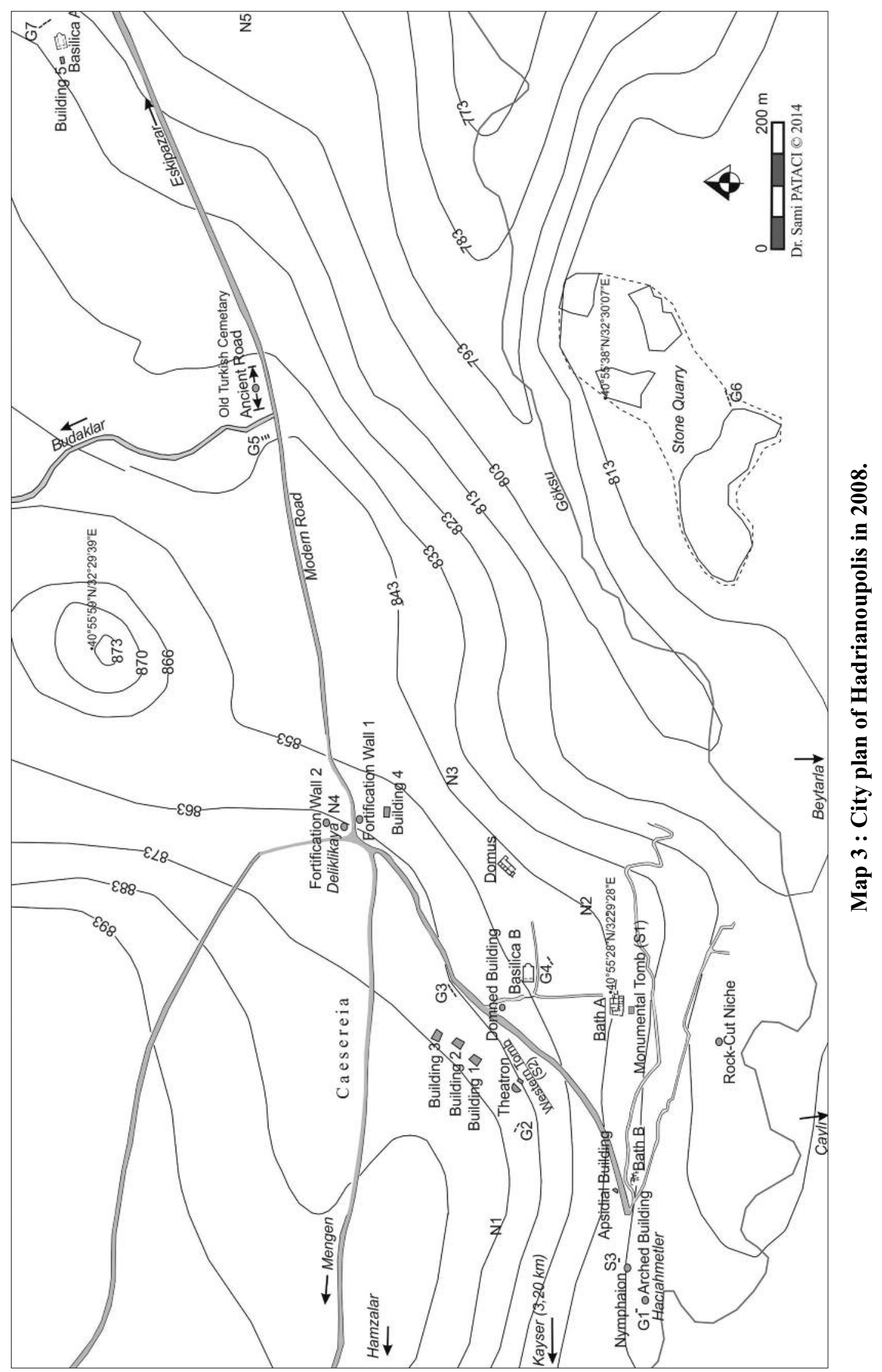


$11^{\text {th }} /$ early $12^{\text {th }}$ cent. In this period there was a massive urban abandonment, because of the Arab conflicts, high instability and steady collapse of Byzantine control over the region between Gangra-Germanicopolis (Çankırı) and Hadrianopolis. At this time inhabitants of Hadrianoupolis were forced to abandon their town in a valley floor to more rugid places east of Eskipazar ${ }^{15}$.

Historically and archaeologically the Middle Byzantine period of entire Paphlagonia after the Arabian raids in A.D. 720 s is illuminated poorly. What we know about this period is that a 'Nicetas' from Hadrianoupolis attended the Seventh Ecumenical Council of Nicaea in A.D. $787^{16}$. A $10^{\text {th }} / 11^{\text {th }}$ cent. seal of a certain bishop, called 'George' is likely refering to $\mathrm{it}^{17}$. In the church listings the city of Hadrianoupolis was mentioned until the $12^{\text {th }}$ cent., variously in Galatia, Honorias, Obsequium or $\mathrm{Bu}-$ cellarian-Paphlagonia ${ }^{18}$. No local epigraphic sources for the Middle Byzantine period exist in southwestern Paphlagonia.

During $7^{\text {th }}$ and $8^{\text {th }}$ cent. A.D. the Arabs had spectacular attacks on Constantinople and able to conquer important cities and fortresses in Asia Minor, such as Amorium, Ancyra and Dorylaeum ${ }^{19}$, whereas they found rarely their way to Paphlagonia ${ }^{20}$. Two Arabian raids to southwestern Paphlagonia brought the collapse of the Late Antique life and caused some demographic changes in the region around GangraGermanicopolis ${ }^{21}$. The evidence for this assumption is some burials of mid. $8^{\text {th }}-9^{\text {th }}$ cent. which were excavated in 2003 on the floorgrounds of the Basilica B in Hadrianopolis (Fig. 1-2). Arabs, however, did not stay in the region for longer durations.

As mentioned above, after the Arab incursions the mid $8^{\text {th }}$ cent. inhabitants of Hadrianoupolis should especially had been forced to move to the ridge called 'Asartepe', marking the ancient site of Kimistene, $\mathrm{ca} .12 \mathrm{~km}$ northeast of Hadrianopolis (Map 4; and Fig. 3-4 $)^{22}$. This site clearly shows signs of occupation over a long period, with particularly important phases in the Hellenistic and Roman Imperial periods, as surface pottery ranges from the Late Iron Age into the Middle Byzantine period. Hadrianoupolis, however, did not get transformed into a Byzantine " $\kappa \alpha ́ \sigma \tau \rho v^{\text {"23 }}$. In the late $9^{\text {th }}$ and early $10^{\text {th }}$ cent. A.D. the military outpost on Kimistene was occupied by a small garrison or a store unit of the local agricultural products (Fig. 5-6) ${ }^{24}$. As mentioned above, this type of Middle Byzantine fortified hilltop sites are very common in elsewhere of southern Black Sea area, especially in the BIAA survey area around Gangra-Germanicopolis, but also in the chora of Comana Pontica ${ }^{25}$ in the further east. Except Kimistene Middle Byzantine finds in southwestern Paphlagonia, consisting almost entirely of pottery, is scattered, and it seems that this period was only concentrated in this little fortified site on the summit of Kimistene's Acropolis.

By the late $11^{\text {th }}$ cent. Turkish troops and settlers had pushed through Paphlagonia to the Bosporus. An instability attended the rebellions at the time of emperor John II Comnenus in A.D. 1130-1135, when the region of Gangra-Germanicopolis and Castra Comnenum (Roman Timonium, today Kastamonu) swung between rebel and imperial hands on several occasions $^{26}$. The Byzantine defence of Paphlagonia and Honorias against the Turks in the $11^{\text {th }}$ and $12^{\text {th }}$ cent. A.D. is not well documented in historical source ${ }^{27}$. As our latest coin, an anonymous follis of ca. A.D. 1030/1035-1042 from Kimistene (Fig. 7) shows, the area of Kimistene and Hadrianoupolis should be passed to the Turkish-Seljuk hands latest at the late $11^{\text {th }}$ and beginning of $12^{\text {th }}$ cent. A.D. After the $12^{\text {th }}$ cent. there seems to be no more Byzantine coins and any other finds in southwestern Paphlagonia. This article is therefore devoted to the pottery finds between $9^{\text {th }}$ and beginning of $12^{\text {th }}$ cent. A.D., a period between the abandonment of Hadrianoupolis, Kimistene's use as a fortified hilltop site by the remaining local Greek speaking Christians and the arrival of Turks in late $11^{\text {th }}$-early $12^{\text {th }}$ cent.

15) Laflı and Zäh 2008: 713.

16) Lamberz 2004: 65

17) Laurent 1965: n $^{\circ} 1593$.

18) Belke 1996: 156; Cf.: Riplinger et al. 1988; Naumann, Kleem and Kuhn 1988; as well as Kazhdan 1991: 2034 (“Theme").

19) Brandes 1989: 74.

20) Brüggemann 2012: 50.

21) Izdebski 2012: 57; $C f$. Ahrweiler 1962: 30ff. and 13ff.; as well as Charanis 1975: 1-20.

22) For a detailed description of Kimistene: Lafl1 and Christof 2011: 235-241.

23) Generally for kastron: Dunn 1994.

24) $C f$. for a similar picture in Galatian Pessinus: Vermeulen 2003: 382-386. R.J. Matthews' assumption of a "steady rural collapse" beginning in A.D. 700 and lasting until the Seljuk conquest is unsustainable; $c f$. Matthews, Metcalfe and Cottica $2009: 192$.

25) Erciyas 2013: 134: Amaseia (fig. 12, $\mathrm{n}^{\mathrm{os}}$ 4-14; and fig. 13, $\mathrm{n}^{\mathrm{os}}$ 22-26), Dazimon (Doceia) and Coloneia. Also $c f .:$ Erciyas 2014

26) Matthews, Metcalfe and Cottica 2009: 190; Vryonis 1971: 119; as well as Treadgold 1997: 631-632.

27) Matthews, Metcalfe and Cottica 2009: 196. 

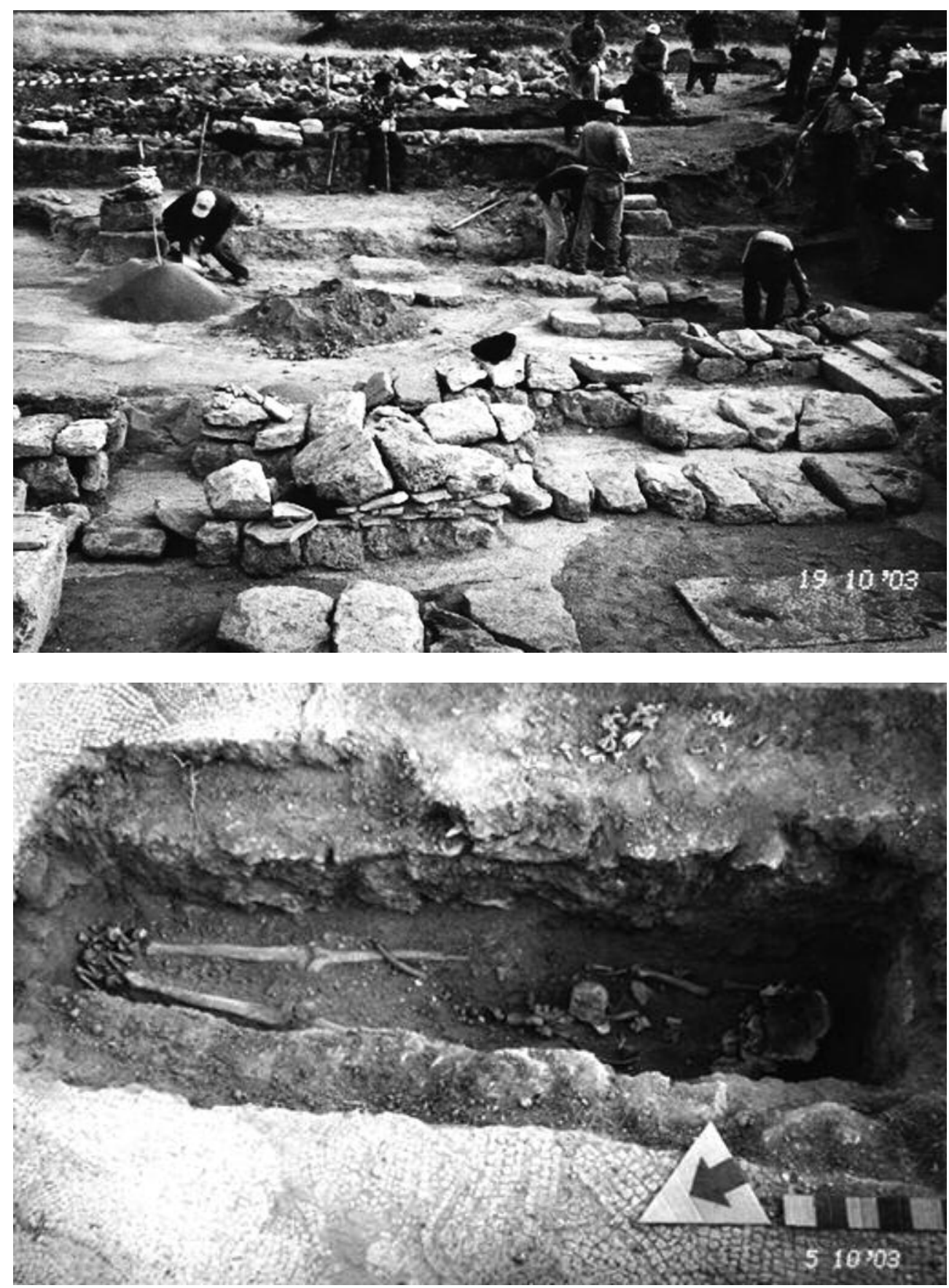

Fig. 1-2 : Middle Byzantine burials on the ground of the Basilica $B$ in Hadrianoupolis, found during the 2003 rescue excavations by the Museum of Ereğli in Zonguldak. Middle $8^{\text {th }}-9^{\text {th }}$ cent. A.D. 


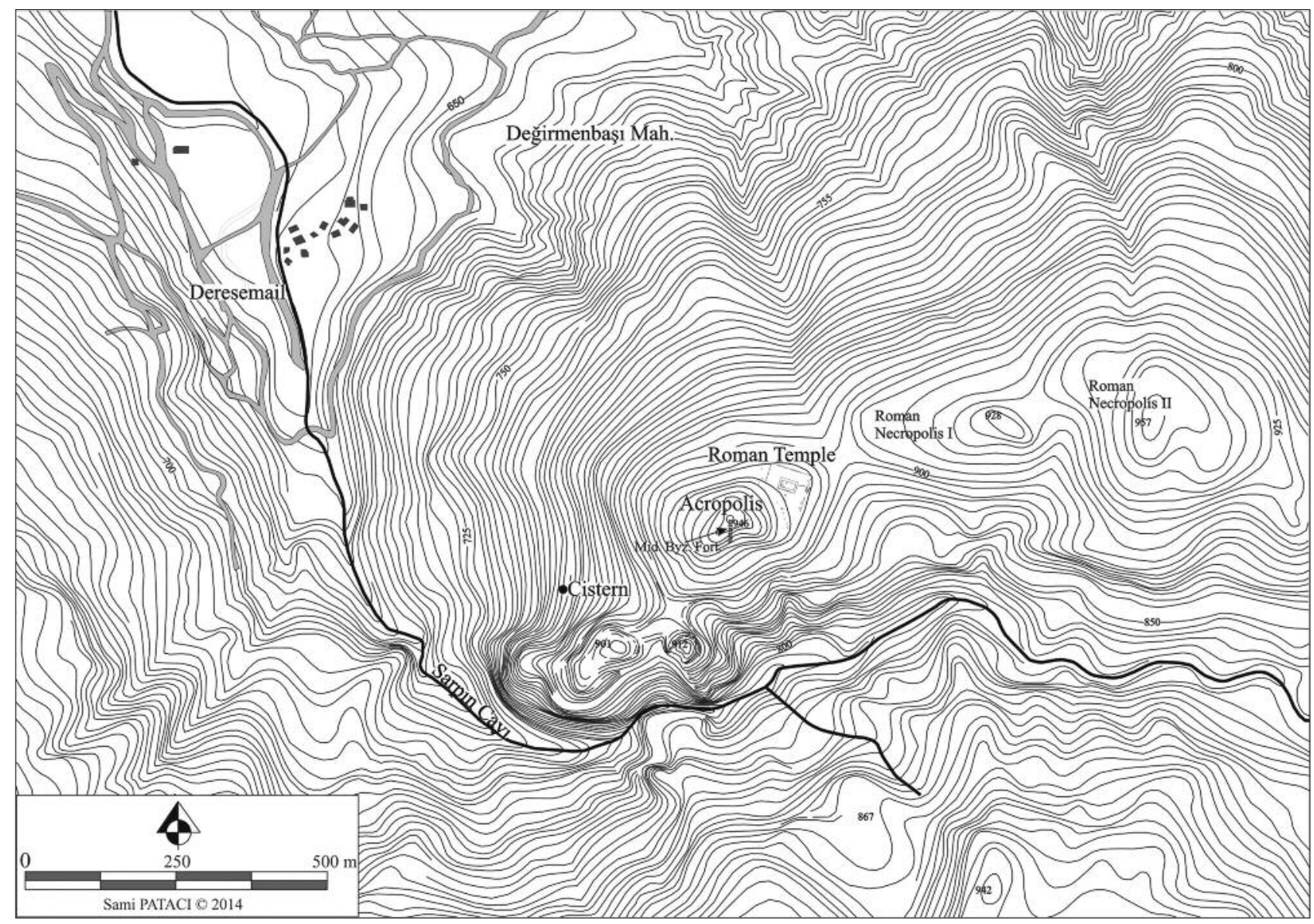

Map 4 : Plan of Kimistene during the Byzantine period (2008).

Fig. 3 : Kimistene-

Asartepe from

Örenarkası with its

surveyed areas in

2005; view from the

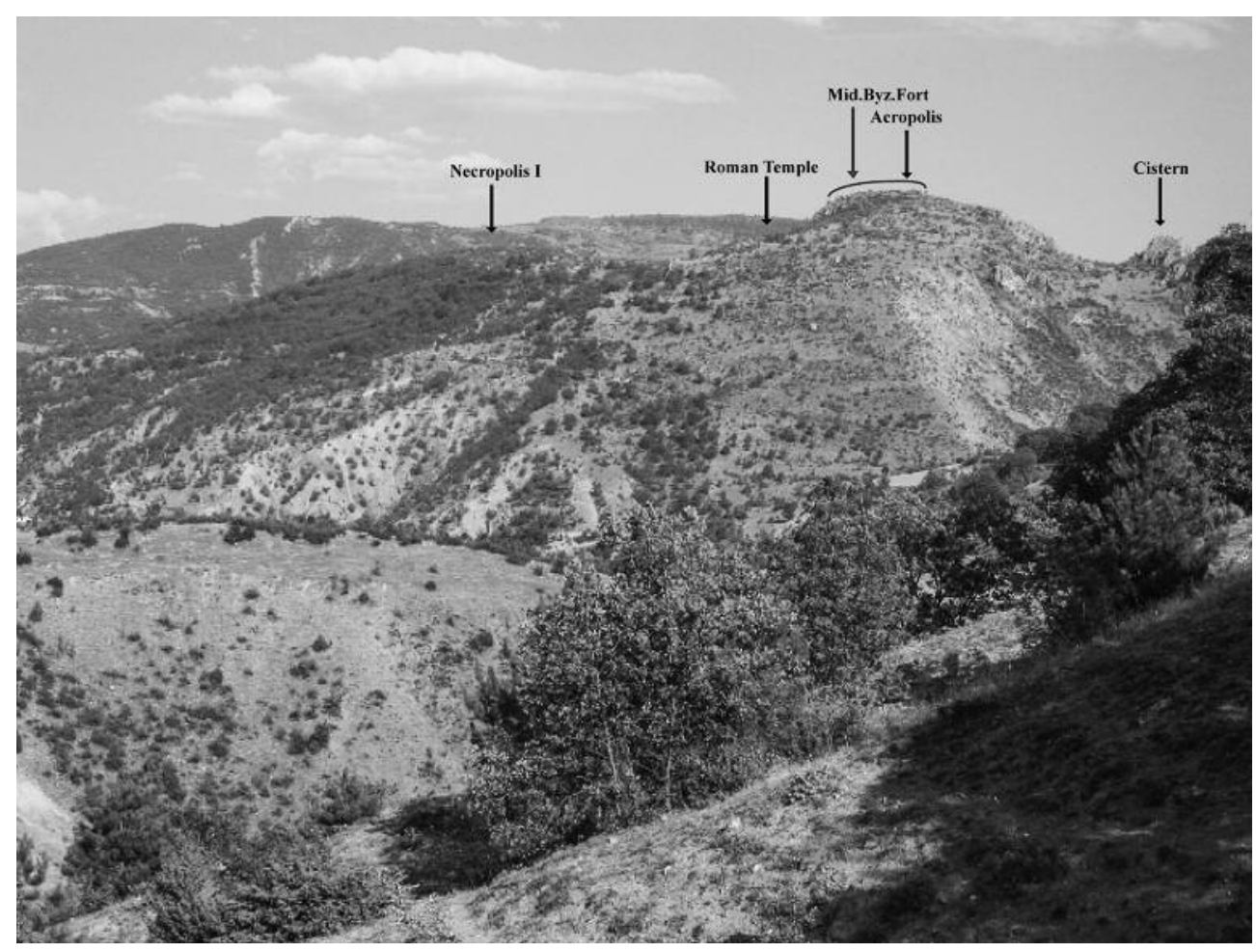

west. 
ERGÜN LAFLI and GÜLSEREN KAN ŞAHIN
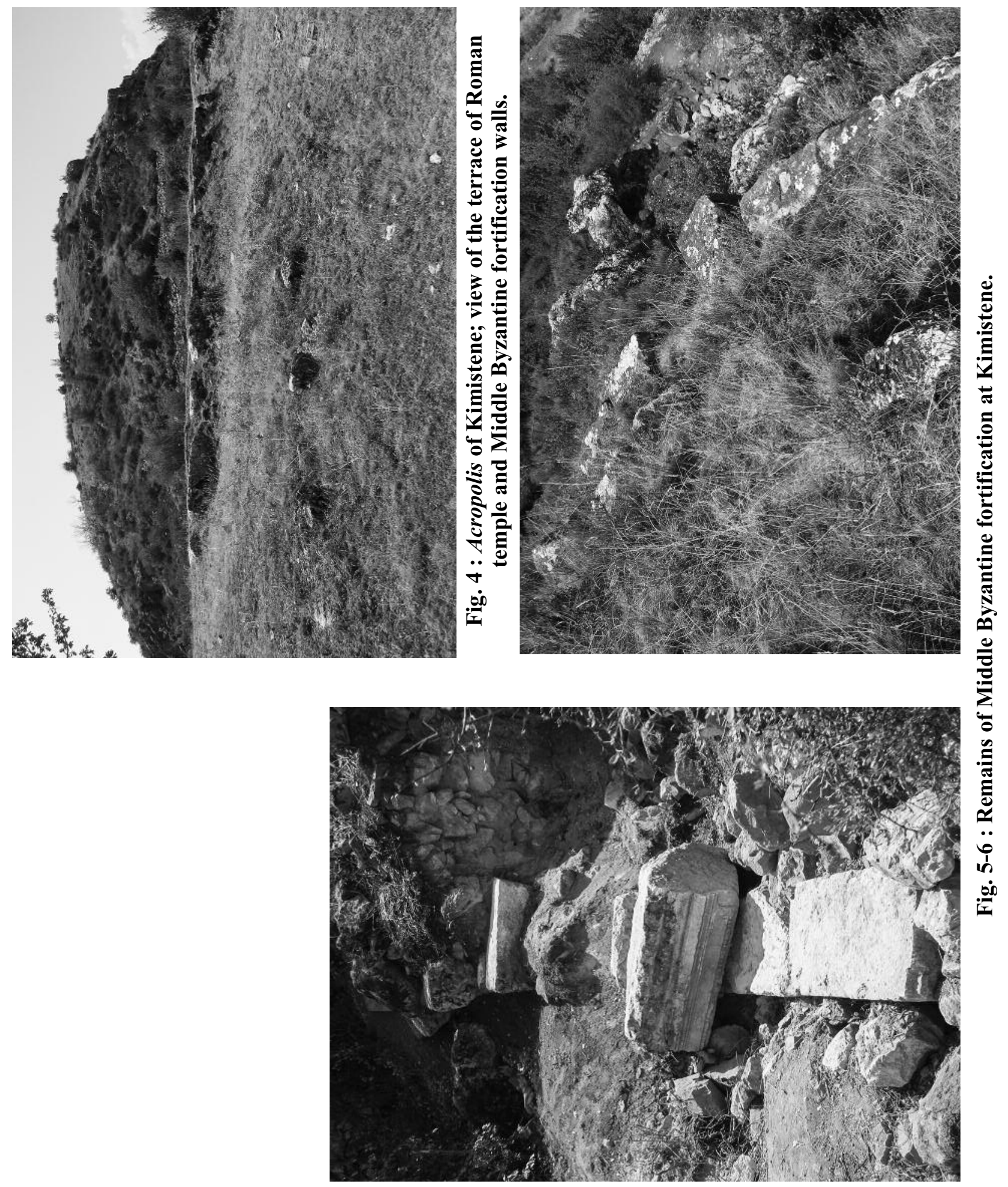


\section{MIDDLE BYZANTINE POTTERY DEPOSITS IN SOUTHWESTERN PAPHLAGONIA}

In previous pottery reports of the DEU Hadrianoupolis Project pottery deposits in southwestern Paphlagonia are listed according to each period and described in detail. The chronology of pottery finds from southwestern Paphlagonia is mostly based on the evidence of coinage and weak stratigraphic units (Table 1). The Middle Byzantine pottery from southwestern Paphlagonia are collected from the following areas: from the Acropolis and elswewhere at Kimistene, Boncuklar, Emiroğlu, Örenarkası (or Göletarkasi) and Kepez as well as excavations at the Bath A, domus, Bath B and western tomb in Hadrianoupolis. Most of the Middle Byzantine pottery finds originate from the Acropolis of Kimistene that offers us two major archaeological surface contexts: On the northern and western slopes of its Acropolis there was a primitive Middle Byzantine fortification with numerous re-used blocks from the Roman temple on the Acropolis' northern edge ${ }^{28}$ (Fig. 5-6). On the summit of the Acropolis there must had been a Middle Byzantine observation post, datable through the pottery finds to the late $9^{\text {th }}$-early $10^{\text {th }}$ to late $11^{\text {th }}$ early $12^{\text {th }}$ cent. A.D., used for observing the route from Ancyra to Amastris/Tium. Most of the surface pottery from this fortification and summit of Acropolis belongs to the Middle Byzantine period, whereas few Late Roman-Early Byzantine coarse ware is existing. Neither tiles, nor ceramics, however, appear in any huge quantities. This find group offers us a terminus ante (late $9^{\text {th }}$-early $10^{\text {th }}$ cent.) and a terminus post quem (late $11^{\text {th }} /$ early $12^{\text {th }}$ cent.), as the area was used for nearly 150-200 years. In this unique surface assemblage most of the pottery is comprised of undecorated wheelmade coarse vessels. Regarding the identification and interpretation of the pottery it is certain that main function of the Middle Byzantine pottery from Kimistene had mostly been that of a common, everyday utensil of storage and of transport in short distances. These functions reveal themselves in fabrics, surface treatments and shapes of each vessels. Middle Byzantine rural community of Kimistene was unlikely to be consumers of luxury goods. These coarse wares are usually awkward to date precisely, whereas some surface coarse wares cannot be assigned to any particular period. Tiles are even more difficult to assign to a specific period $^{29}$.
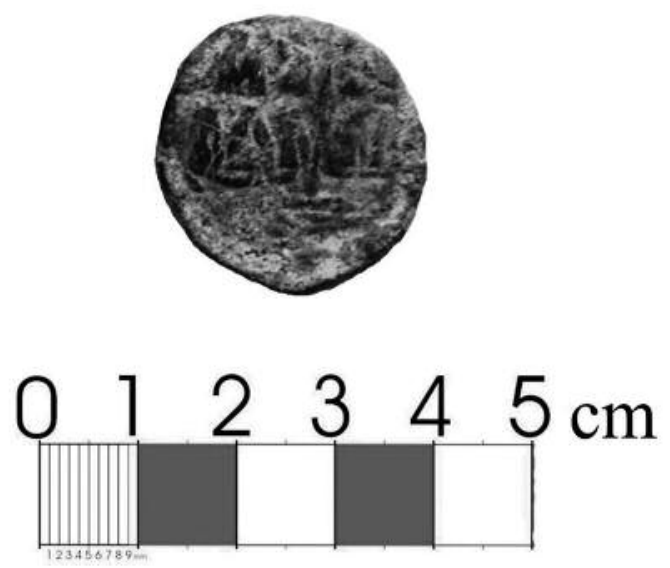

Fig. 7 : An anonymous follis of ca. A.D. 1030/1035-1042 from the Acropolis of Kimistene.

The second collection area is the rest of Kimistene, below the Middle Byzantine fortification, among others the cistern (Fig. 8) and two necropoleis: Surface finds from the area below the Middle Byzantine fortification ranges from the Late Iron Age into the Middle Byzantine period, whereas majority of sherds belongs to the Hellenistic and Roman periods, i.e. $1^{\text {st }}$ cent. B.C. to the $3^{\text {rd }}$ cent. A.D. In this area Middle Byzantine sherds are few.

Middle Byzantine pottery finds from southwestern Paphlagonia are sparse, infrequent and singular. Very few Middle Byzantine sherds were collected in Hadrianoupolis in the course of 2005-2008 field seasons. The districts of Haciahmetler, Eleler, and Çaylı of the village of Budaklı formed the core of Byzantine Hadrianoupolis. A fortification wall, called as 'Deliklikaya' (Fig. 9) and probably belonging to the after $8^{\text {th }}$ cent. A.D., surrounded the Acropolis of the city. During the Middle Byzantine period life at the city of Hadrianoupolis seems to be very weak and sole archaeological record is the above mentioned burials of $8^{\text {th }}-9^{\text {th }}$ cent. in the Basilica B. In this period no architectural features were identified at Hadrianoupolis, apart from few possible architectural elements (Fig. 10), probably belonging to a local church. Small quantity of domestic assemblages were collected in public buildings, such as Bath A and $\mathrm{B}$, mostly in fragmentary nature that could indicate that these buildings were in secondary use, perhaps converted into a barn.

Few Middle Byzantine pottery was discovered at Kepez, a site $c a .12 \mathrm{~km}$ southeast of Hadrianoupolis. Also in the Village Emiroğlu some sherds were collected.

28) Lafl1 and Christof 2011: 235.

29) This case is also been observed at the surveys of the BIAA in Inner Paphlagonia: Matthews, Metcalfe and Cottica $2009: 173$. 
Table 1: Find spots of Middle Byzantine pottery in southwestern Paphlagonia.

\begin{tabular}{|c|c|c|c|}
\hline Find Spots & Date of their Usage & Numismatic Evidence & $\begin{array}{l}\text { Genres of Middle Byzantine } \\
\text { Pottery from these Findspots }\end{array}$ \\
\hline Bath A & $\begin{array}{l}\text { Early } 1 \text { st-mid. of } 19^{\text {th }} \\
\text { A.D., with the concentration } \\
\text { of early } 6^{\text {th }} \text {-late } 7^{\text {th }} \text { cent. A.D. }\end{array}$ & $\begin{array}{c}\text { A coin of Justin I (A.D. 518-527); } \\
\text { a coin of Justinian I (A.D. 527-565); } \\
\text { a coin of Heraclius (A.D. 610-641); } \\
\text { a coin of Constans II (A.D. 641-668); } \\
\text { two anonymous folloi of A.D. } 976-c \text {. } \\
\text { 1030/1035; a signed follis of } \\
\text { Constantine X and Eudocia } \\
\text { (A.D. } 1059-1067 \text { ) and a signed } \\
\text { follis of Romanus IV } \\
\text { (A.D. } 1068-1071 \text { ); numismatic } \\
\text { range between A.D. } 518 \\
\text { to 1071 }\end{array}$ & $\begin{array}{l}\text { Tableware, transport ware and } \\
\text { miscellaneous ceramics }\end{array}$ \\
\hline Bath B & $\begin{array}{l}7^{\text {th }}-12^{\text {th }} \text { cent. A.D., with the } \\
\text { concentration of early } \\
7^{\text {th }} \text {-early } 8^{\text {th }} \text { cent. A.D. }\end{array}$ & $\begin{array}{l}\text { Two coins of Heraclius (A.D. } 610- \\
641 \text { ); and a coin of Constantine IV } \\
\text { (A.D. } 668-685 \text { ); numismatic range } \\
\text { between A.D. } 610 \text { and } 685\end{array}$ & $\begin{array}{l}\text { Tableware, kitchen ware and } \\
\text { miscellaneous ceramics }\end{array}$ \\
\hline Domus & $\begin{array}{l}\text { Mid } 6^{\text {th }} \text { to the mid } \\
7^{\text {th }} \text { cent. A.D. }\end{array}$ & $\begin{array}{l}\text { A coin of Justinian I (A.D. 527-565) } \\
\text { and four coins of Heraclius } \\
\text { (A.D. } 610-641 \text { ); A numismatic range } \\
\text { between A.D. } 527 \text { and } 641\end{array}$ & Tableware \\
\hline Western Tomb & $\begin{array}{c}\text { Late } 2^{\text {nd }} \text {-mid of } 3^{\text {rd }} \text { cent. AD.; } \\
\text { disturbed and mixed }\end{array}$ & No coins & $\begin{array}{l}\text { Tableware, transport ware and } \\
\text { miscellaneous ceramics }\end{array}$ \\
\hline Örenarkası & $5^{\text {th }}-6^{\text {th }}$ cent. A.D. & No coins & Kitchen ware \\
\hline Boncuklar & $\begin{array}{l}1^{\text {st }}-2^{\text {nd }} \text { cent. A.D.; } \\
4^{\text {th }}-5^{\text {th }} \text { cent. A.D. }\end{array}$ & No coins & Storage ware \\
\hline $\begin{array}{c}\text { Kimistene, Summit of } \\
\text { Acropolis, observation post }\end{array}$ & $\begin{array}{c}\text { Mid of } 9^{\text {th }} \text {-late } 11^{\text {th }} / \text { early } \\
12^{\text {th }} \text { cent. A.D. }\end{array}$ & $\begin{array}{c}\text { An anonymous follis } \\
\text { (ca. A.D. 1030/1035-1042) }\end{array}$ & $\begin{array}{l}\text { Tableware, kitchen ware, } \\
\text { storage ware, transport ware, } \\
\text { miscellaneous and } \\
\text { achitectural ceramics }\end{array}$ \\
\hline $\begin{array}{l}\text { Kimistene, elsewhere in } \\
\text { Acropolis, Necropolis I and } \\
\text { II as well as Cistern }\end{array}$ & $1^{\text {st }}$ early $7^{\text {th }}$ cent. AD. & No coins & $\begin{array}{l}\text { Tableware, kitchen ware, } \\
\text { storage ware, transport ware, } \\
\text { miscellaneous and } \\
\text { achitectural ceramics }\end{array}$ \\
\hline Kepez & $\begin{array}{l}1^{\text {st }}-3^{\text {rd }} \text { cent. A.D.; Late } \\
8^{\text {th }} \text {-late } 11^{\text {th }} \text { cent. A.D. }\end{array}$ & No coins & $\begin{array}{l}\text { Tableware, kitchen ware, stor- } \\
\text { age ware and miscellaneous } \\
\text { ceramics }\end{array}$ \\
\hline Emiroğlu District & Mixed & No coins & $\begin{array}{l}\text { Only a sherd of a } \\
\text { storage ware }\end{array}$ \\
\hline $\begin{array}{c}\text { Surface Finds from } \\
\text { Hadrianopolis } \\
\text { (from an unidentified } \\
\text { Byzantine building close } \\
\text { to the Domus) }\end{array}$ & Mixed & $\begin{array}{l}\text { A coin of possibly Justinian II, first } \\
\text { reign (A.D. 685-695) or little later } \\
\text { (max. A.D. } 717)\end{array}$ & $\begin{array}{l}\text { Tableware, storage ware and } \\
\text { transport ware }\end{array}$ \\
\hline
\end{tabular}



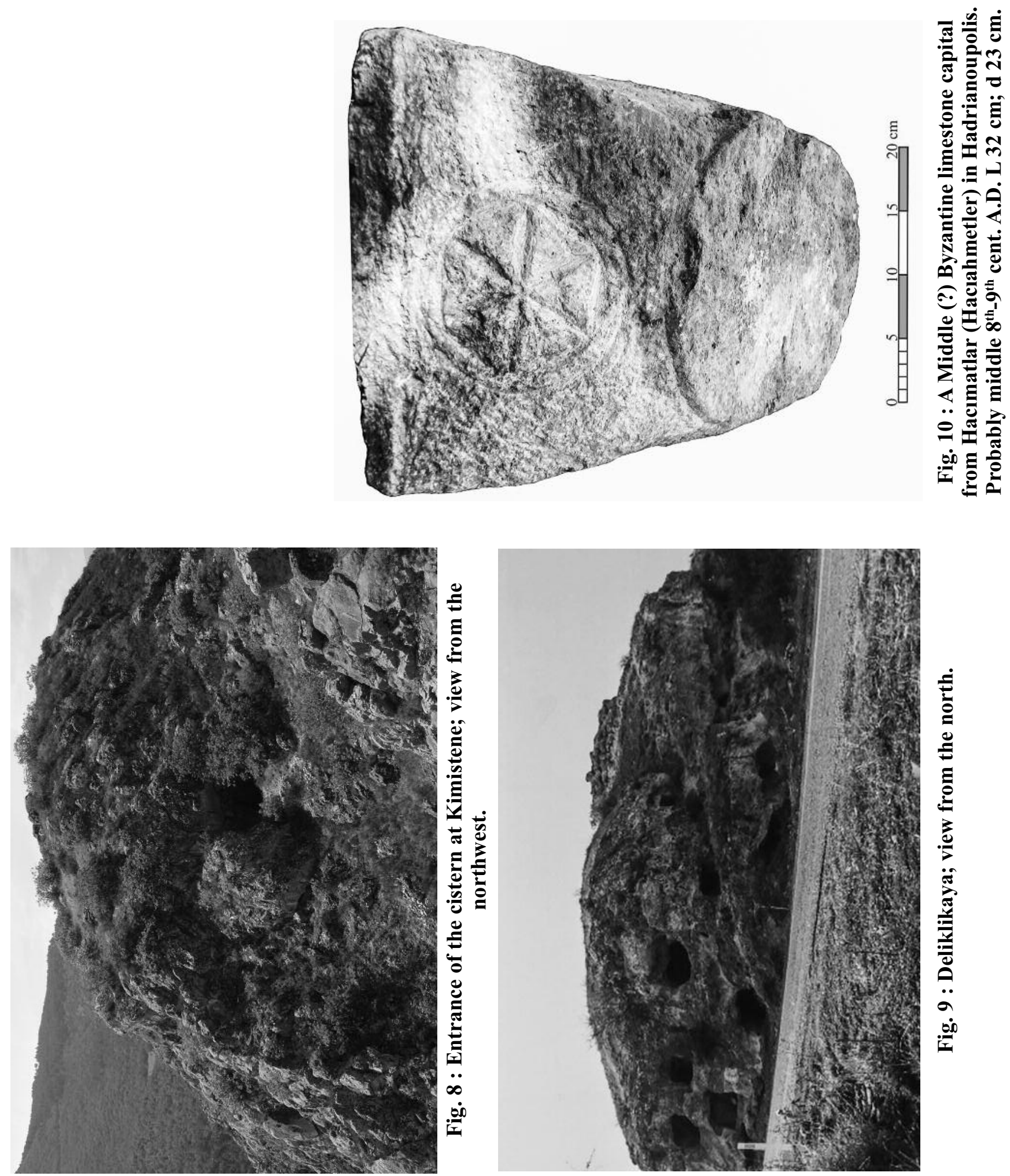


\section{GENERAL CHARACTERISTICS OF MIDDLE BYZANTINE POTTERY FINDS}

Most of the Middle Byzantine pottery finds from southwestern Paphlagonia are coarse wares; few glazed wares were found ${ }^{30}$. The material is mostly consisting of rim, base, handle and body fragments of jugs, cooking pots, storage vessels, amphorae, jars as well as tiles and water pipes. Middle Byzantine architectural ceramic finds, i.e. pipes, tiles and bricks, were also included here, because of their similar fabric and firing characters to storage vessels.

Until recently publication of Middle Byzantine unglazed pottery in Asia Minor was routinely ignored, with the notable exception of some finds from Istanbul ${ }^{31}$. John W. Hayes argued that the $7^{\text {th }}$ to $11^{\text {th }}$ cent. tablewares and cooking wares from Istanbul had little in common with products found in the peripheral Byzantine and non-Byzantine areas. New production centres of pottery emerged in this period, using new shapes and decoration technics, and distribution patterns changed rapidly. Especially during the $11^{\text {th }}$ and $12^{\text {th }}$ cent., with the appearance of widely used glazed wares with painted or sgraffito decoration, 'a greater uniformity of taste in pottery styles' was apparently emerged in the Middle Byzantine world. In southwestern Paphlagonia no such painted or sgraffito decorated vessels, however, were found.

Generally in Middle Byzantine ceramic archaeology characteristics of coarse ware determine the wall thickness of a vessel, which itself determines the function: larger rough vessels require thicker walls, designed for storage, while vessels for cooking require thinner walls which better conduct heat ${ }^{32}$. Ceramic vessels used for food preparation, cooking, serving, consuming, storage and transport have been the main evidence for dating and studying social changes during all periods and at all social levels. Although long considered as essentially a dating agent on archaeological sites, coarse wares also offer an indirect indicator of economic, social and cultural behaviour and as very functional daily objects they are one of the best substitution of the Byzantine instrumenta domestica in Asia Minor ${ }^{33}$. As far as the Byzantine and Medieval periods are concerned, scholarly attention has generally focused on glazed and decorated tablewares, but the sherds of unglazed common wares that make up the bulk of the ceramic remains at any site can be used to reconstruct many features of everyday life $^{34}$. The ceramics of the Middle Byzantine period in Asia Minor are particularly problematic to identify and date for several reasons: we have few adequate pottery sequences which indicate what the development of coarse wares and non-glazed tablewares looked like in this period ${ }^{35}$.

Middle Byzantine pottery finds from southwestern Paphlagonia have been divided into six minor vessel groups, and in each group open shapes are followed by the closed shapes. Our main pottery assessment is based on fabric. These six main groups are: tableware, kitchen ware, storage ware, transport ware, miscellaneous fragments of coarse ware vessels and architectural ceramics. Typologies in this paper are mainly made by diagnostic rim and base sherds. Miscellaneous fragments of coarse ware vessels, such as base, handle and body sherds of mostly closed, unknown shapes are also classified in this article. A fragment of a terracotta spindle whorl has also been added to this last group. Also in some cases sherds are very fragmentary; it therefore is difficult to estimate their vessel shape. Thus, some of the classifications are uncertain, and most sherds were not diagnostic at all. Middle Byzantine coarse vessels from southwestern Paphlagonia consist of generally thin walled fragments.

Decoration technics on Middle Byzantine coarse ware from southwestern Paphlagonia are painting, incising and impressing, even though few vessels are decorated, and their decoration remained the same for a long time. Most of these decorations were made carelessly. Most popular decoration pattern was thin wavy grooves. Exterior surfaces or rims were often ridged, and sometimes decorated with horizontally, incised straight or with wavy lines (pls. 2, 16, 18, 25-

30) A preliminary report on these finds: Laflı and Kan Şahin 2010.

31) Hayes' publication of the excavations at Saraçhane is one of the few sources that provide a good dating of these wares in a stratigraphic Anatolian context: Hayes 1992: 61-79. It is an unfortunate that recent rescue excavations in Istanbul do not offer any extensive stratigraphic data for a better dating than St. Polyeuctus.

32) Vionis et al. 2010: 433. Prudence M. Rice presents detailed a discussion of vessel function in terms of form and technology: Rice 1987: 207-243.

33) Bes 2015: 278.

34) Vionis et al. 2010: 432. For the chronology, function and classification of Post-Roman pottery, especially in the Aegean, see, since 1980s e.g., Sanders 1987, 2000 and 2003; Hayes 1992; Bakirtzis 1980 and 1989; Armstrong 1996 and 2006; Papanikola-Bakirtzi 1996 and 1999; Vroom 1998, 2003 and 2004; Vionis 2001, 2006a and 2006b; Dori, Velissariou and Michailidis 2003; as well as Blake 2005.

35) Cassis 2015: 311. 
27 and $29, \mathrm{n}^{\text {os }} 37,130,197-199,201-203,206,208$, 212-213, 237-240 and 257). An incised decoration on a base fragment is also seen on $\mathrm{n}^{\circ} 137$ of pl. 17 . Lightly incised wavy lines were also found among the Middle Byzantine pottery from Saraçhane ${ }^{36}$, Hierapolis $^{37}$, Amorium $^{38}$, Sagalasssus ${ }^{39}$, Tripolis ${ }^{40}$, Taşkun $\mathrm{Kale}^{41}$ in eastern Anatolia, Gritelle ${ }^{42}$, Zeytinlibahçe ${ }^{43}$ and Sazpegler ${ }^{44}$. Impressed decoration (pls. 11, 18 and 23 and 29, $n^{\text {os }} 104,157-160$ and 260) had been engraved on exterior surfaces through finger, nails or seals before the firing. On some closed samples impressed decoration had been applied on a band (pls. 10,14 and 28, $\mathrm{n}^{\text {os }} 101,118$ and 256). One glazed vessel fragment (pl. 1, $\mathrm{n}^{\circ} 6$ ) has an impressed decoration as well. Decorative bands were made as horizontal strips on the exterior (pls. 12, 18, 23 and 29, $\mathrm{n}^{\text {os }} 110$, 131, 157, 159-160, 166 and 258).

Tablewares belong to a functional coarse ware category that comprises glazed and unglazed vessels, used for the serving and consumption of food as well as beverages. Most common forms of Middle Byzantine Paphlagonian coarse tableware are dishes, juglets and jars. The most common form of the glazed wares is a bowl form with thin and incurving walls. The fabric of glazed vessels is hard, red/reddish yellow and included small limes. Their homogenous and porous fabric has some brownish/reddish mineral inclusions. These glazed fragments are undecorated and were left plain. Rest of the tableware mostly consists of closed forms.

The scanty number of tableware typologies in southwestern Paphlagonia makes us to think that most of the coarse ware was used for storage purposes and for the food consumption the Middle Byzantine community in southwestern Paphlagonia had probably used wood. Fragments of unglazed everyday bowl and dish forms in coarse fabric (pls. 1-2, $\mathrm{n}^{\text {os }} 10-23$ ) are rather rare. The shape of a bowl form (pl. 1, $\mathrm{n}^{\circ}$ 18 ) suggests a metal prototype, although this does not help in providing a precise date, and similar shapes are well known among the Middle Byzantine glazed ceramics ${ }^{45}$.
The table jugs (pls. 2-4 and 22, $\mathrm{n}^{\text {os }} 30-55$ ) have mostly a flaring, everted or constricted rim, a narrow neck and a vertical handle. Most of these wares are belonging to thin-walled vessel forms. Different rim shapes of table jug and pitchers are intended to contain, carry or pour some certain liquids ${ }^{46}$ : Generally their lip forms are rounded (pls. 2-3, $\mathrm{n}^{\text {os }} 32-33,38$, 40, 42-43 and 45), straight (pl. 2, $\mathrm{n}^{\circ} 36$ ), thickened out (pls. 2-4, nos 35,41 and 49-50) or folded out (pls. 3-4, $\mathrm{n}^{\text {os }} 39$ and 47). They often have strap handles that attached upright rim for functional purposes.

Middle Byzantine table and transport vessels, such as bowls, jugs, pots and amphorae, have a similar fabric to each other. Most common inclusions are lime, sand, quartz and mica; this is especially observed at closed vessels, such as at table jugs. Mineral inclusions are rather more intensive than the organic ones, and they are to be observed on the surface of the profiles. Compared to former periods, the density of temper (mica, lime and sand) is decreased, their fabric is softer (3.5 on the Mohs scale) and not very well fired.

On the slipped vessels there is always a thin and darker slip on the whole surface which ranges between green, yellow and brown. Sometimes the same slip had been applied in different shapes (pls. $2-5,15,18$ and $23, \mathrm{n}^{\text {os }} 22,42,50,56,58,122,151$ and 163). Most of the surface of tablewares is well smoothed which is their distinctive exterior surface decoration for the Middle Byzantine period.

In southwestern Paphlagonia during the Middle Byzantine period some burnished rim and body fragments were ornamented with vertical and diagonal burnished lines ${ }^{47}$ (pls. 2-3, 5-7, 15, 17-18, 22-24 and $26-29, \mathrm{n}^{\text {os }} 22,25,29,37,42-43,59,67-69,71$, $122,124,147,151,153,163-164,174-175,219-$ $221,232-233,250$ and 258). Their surface is polished or burnished which produces a shiny effect. This decoration is made by a blunt tool across the wetsmoothed surface ${ }^{48}$. The fabric is fairly hard, fine and brick-red in colour, and reminds of the fabrics

36) For several types of unglazed pottery: Hayes 1992: 49-79.

37) For some Middle Byzantine coarse ware ceramics: Arthur 2012: 280-285, fig. 10.5.

38) Lightfoot et al. 2004: 364. fig. d, n ${ }^{\circ}$ 1; and Böhlendorf-Arslan 2012: 153-162.

39) Middle Byzantine common wares: Vionis, Poblome and Waelkens 2009: 198, fig. 4.

40) Middle Byzantine local pottery: Duman 2014: 225-230, figs. 2-3.

41) McNicoll 1973: 176-180, figs. 14-15.

42) Redford 1986: 118, fig. 6.

43) Alvaro, Balossi and Vroom 2004: 204-206, figs. 11-15.

44) Tekinalp and Ekim 2005: 236, pl. 50, $\mathrm{n}^{\circ} 3$.

45) Lightfoot et al. 2004: 364-365.

46) Fulford 1984: 155

47) A similar rim profile: Vionis, Poblome and Waelkens 2009: 156, fig. 8.

48) Armstrong 1998: 324. 
of 'brittle ware cooking pots' from southeastern Turkey and northern Syria, whereas its origin is not yet known ${ }^{49}$.

Middle Byzantine kitchen wares were utilised mainly for the food preparation and cooking. P. Arthur has recently shown that throughout the ancient world, the distribution of open cooking pots or casseroles seems to coincide with the distribution of areas in which faunal assemblages are dominated by sheep and goat, whereas closed globular cooking vessels (or ollae) are generally a feature of more northern areas, i.e. from Britain across the Rhineland to central Europe, where cattle- and pig-breeding was dominant ${ }^{50}$. In southwestern Paphlagonia cooking pots are distinguished by their typical rim forms, thickness and coarse, gritty fabric that was mineral tempered to encourage heat conduction ${ }^{51}$. They are represented by casseroles, pots and basins with a weak and slow morphological evolution. Their open forms are generally deep and shallow. The most common types have a vertical wall with an everted rim, globular body and vertical handles. Two open examples have a globular form (pl. 5, $\mathrm{n}^{\text {os }}$ 61-62); others have straight walls. Some of the kitchen wares are provided with a grooved rim inside for holding a lid (pls. 5-7, $\mathrm{n}^{\text {os }} 56,58,65,68-69$ and 71). Basins/large bowls have a heavy, wide and downturned rim, and they might be used as mixing bowls (pls. $\left.6-7, \mathrm{n}^{\text {os }} 68-71\right)$. Cooking pots with handles that start at the top of the rim are common at numerous Middle Byzantine sites ${ }^{52}$, whereas some cooking vessels have a handle under their rim (pl. 7, $\mathrm{n}^{\circ} 82$ ). Middle Byzantine cooking vessels have a very sandy and limy, less gritty fabric with medium-sized mineral inclusions. Colour of their fabric ranges from beige and light brown to darker brown tones. Their thin walls have generally blackened surfaces.

As in traditional rural Aegean societies of today, it seems that the average Medieval and Post-Medieval Mediterranean household required two distinct types of pottery: storage and transport ware ${ }^{53}$. Storage vessels are represented merely by pithos fragments and they were used for domestic purposes and agricultural, especially grain storage (Fig. 11). Some examples, as $\mathrm{n}^{\text {os }} 60$ and 62 on pl. 52, were used as water containers. Few body sherds of the storage vessels are present. Storage vessels have irregular and medium size inclusions. Their paste colours changes from reddish to brownish, yellowish and greenish grey.

Very few fragments of transport amphorae, perhaps of local origin, were found. These amphorae were used not only as transport ware, but also for the storage as a secondary use until $13^{\text {th }}-14^{\text {th }}$ cent., when the wooden barrels became popular in the eastern Mediterranean ${ }^{54}$.

49) Vroom 2007: 281.

50) Arthur 2007: 18; and Vionis et al. 2010: 458

51) This is the same phenomenon, observed in the surveys of the BIAA: Anderson 2011: 111.

52) Similar rim profiles: Böhlendorf-Arslan 2012: 154, fig. 2/5; and Papanikola-Bakirtzi 2002: $344, \mathrm{n}^{\circ} 390,346-347, \mathrm{n}^{\text {os }} 395-396$, and 348, $\mathrm{n}^{\text {os }} 397-399$. For early $12^{\text {th }}$ cent. 'cooking pots' from Middle Byzantine contexts at Saraçhane: Hayes 1992: 134, 196, fig. 76: $50.31 ; 138$, fig. $80, \mathrm{n}^{\text {os }} 50.116$ and 50.119 .

53) Vionis 2001: 84.

54) George Makris mentions that radical change in the technology of sea transport came about, when the clay storage jars gave way to the wooden barrels; this reduced the weight of liquid cargoes by $30 \%$ and made it possible to reduce the size of ships correspondingly. But we do not yet know when the use of wooden storage vessels became general in Byzantine ships: Makris $2002: 94$. 

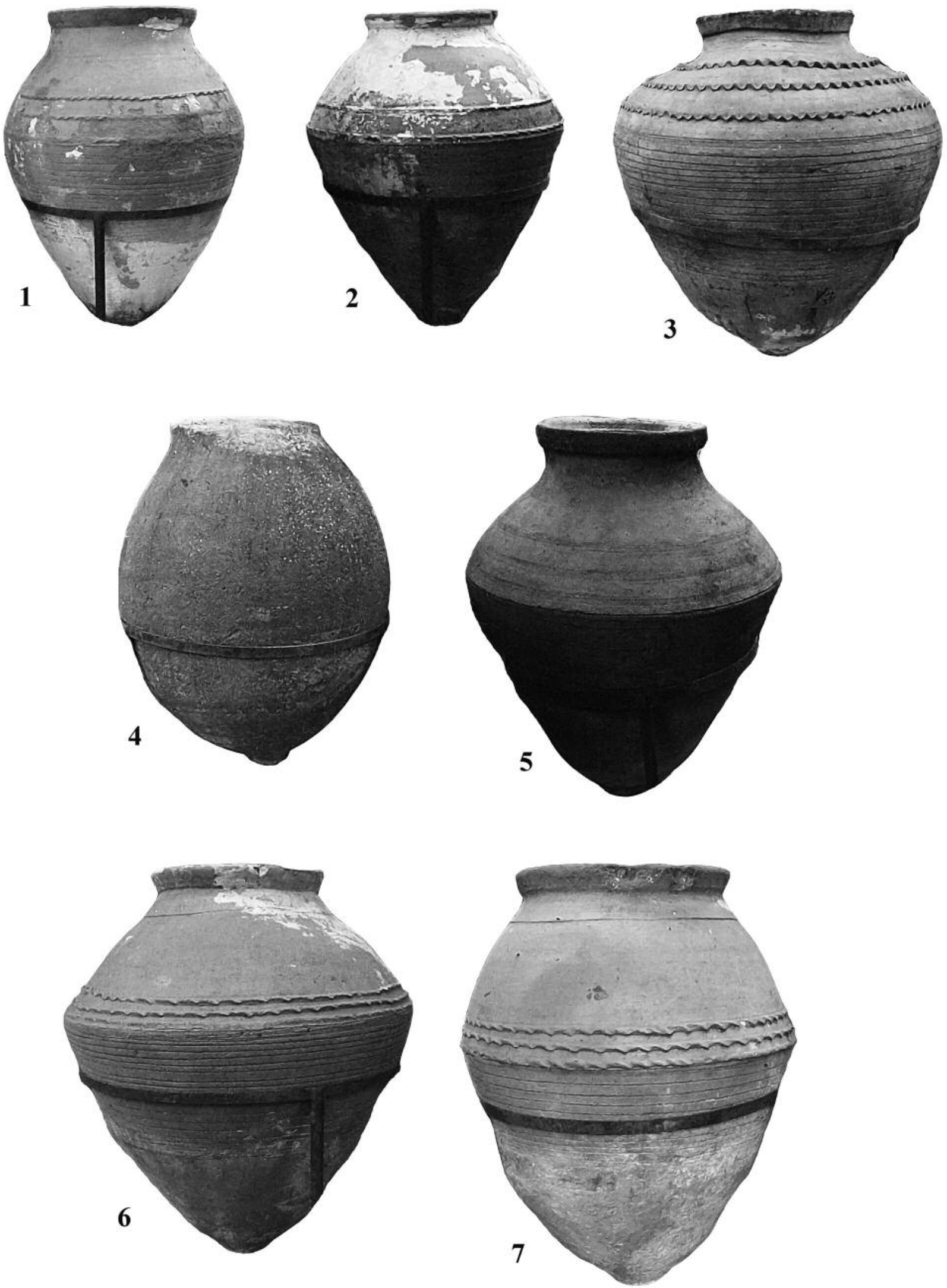

Fig. 11 : Medieval and Post-Medieval pithoi at the Ethnographic and Archaeological Museum of Çanakçılar at Zonguldak. 

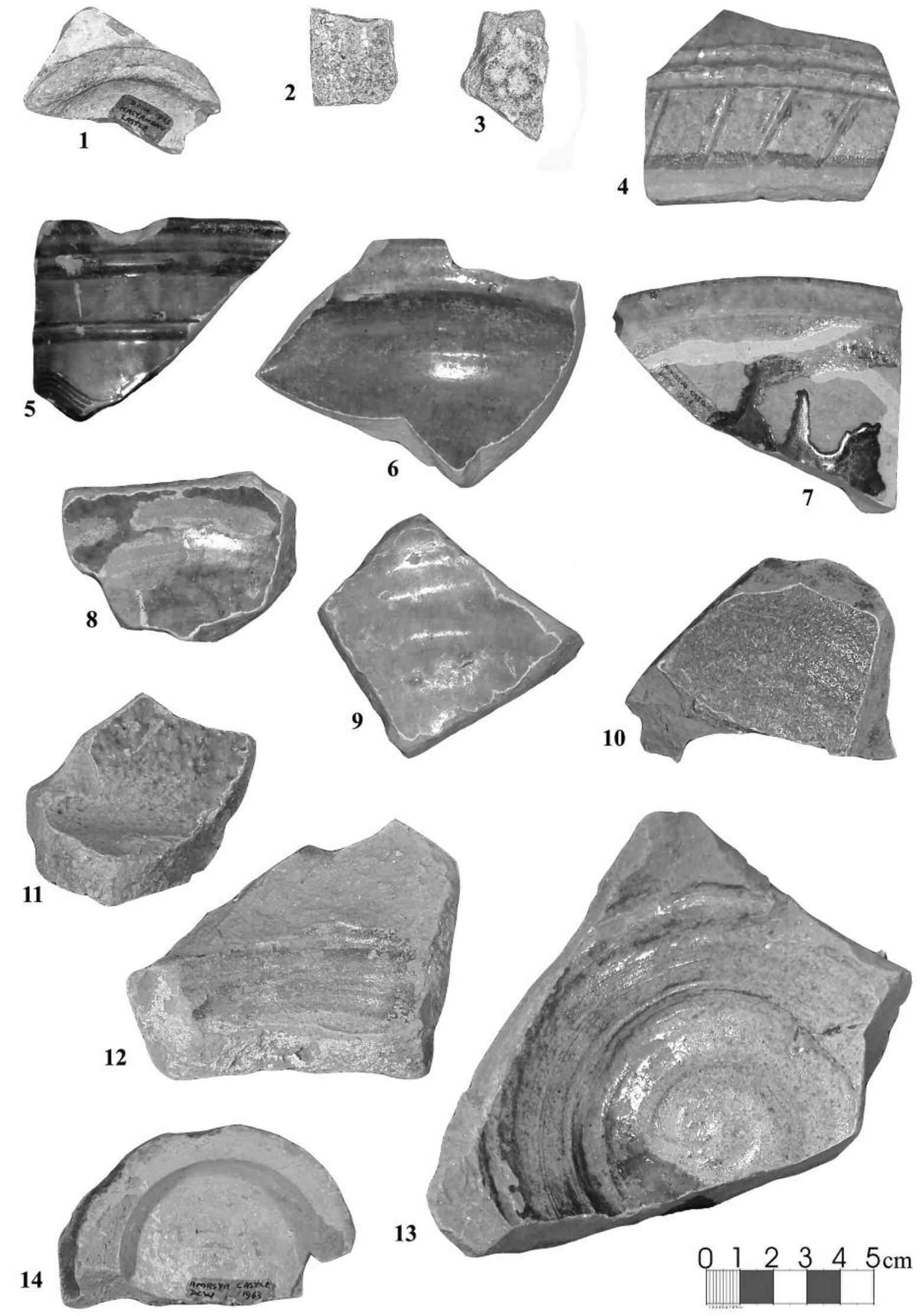

Fig. 12 : Comparative Middle Byzantine surface ceramic sherds from Paphlagonian and Pontic sites at the Pottery Collection of the British Institute of Archaeology at Ankara from a field survey in 1963:

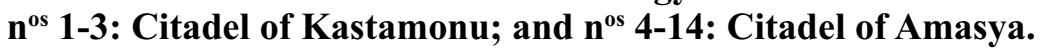




\section{FORM CATALOGUE}

\author{
1. Tableware \\ (pls. 1-4, $\mathrm{n}^{\text {os }} 1-55$; pl. 22, $\mathrm{n}^{\text {os }} 4-31$ )
}

Tablewares are divided into two major groups: Glazed and unglazed tablewares. All of the glazed vessels are monochrome. Unglazed tablewares are mainly consisting of closed forms and some of them are burnished on their exterior surface.

\section{Glazed Vessels \\ (pl. 1, nos 1-6; pl. 22, nos 4-9)}

Only a few and very fragmentary sherds were found. Their (regional?) production is not determined yet, as the rest of glazed ware finds along Inner Paphlagonia and Pontus (Fig. 13-14) ${ }^{55}$. From the late $8^{\text {th }}$ cent. A.D. onwards most of them belong to the open forms, such as bowls and dishes, often with very simple geometric designs, incised into the fabric with a sharp tool ${ }^{56}$. Their glaze colours vary between yellow and olive green, and they have mostly a red-bodied fabric and white slipped surface. Examples from southwestern Paphlagonia should be dated to $10^{\text {th }}-11^{\text {th }}$ cent. A.D.

1- (No 941): Base fragment; Kimistene, Acropolis, pl. $\mathbf{1} / \mathbf{1}$.

Max. h $1.6 \mathrm{~cm}$., d of base $6.2 \mathrm{~cm}$., max. w $3.3 \mathrm{~cm}$., $\max$. th $0.4 \mathrm{~cm}$.

Red (2.5YR 4/6) glaze on exterior and interior. Hard paste; very sparsely porous, fine, light red (2.5YR 6/8) fabric with rare sand and mica inclusions.

$10^{\text {th }}-11^{\text {th }}$ cent. A.D.

2- ( $\mathrm{N}^{\circ}$ 96): Base fragment; Bath $\mathrm{B}$, room 5, surface find, found in 2007.

pl. 1/2.

Max. h $2.4 \mathrm{~cm}$., d of base $9.8 \mathrm{~cm}$., max. w $7.4 \mathrm{~cm}$., max. th $0.5 \mathrm{~cm}$.

Light olive brown (2.5Y 5/4) glaze on exterior; light reddish brown (5YR 6/4) slip on interior. Hard and thin paste; very sparsely porous, fine, pink (5YR 7/4) fabric with some lime as well as sand and rare mica inclusions. $10^{\text {th }}-11^{\text {th }}$ cent. A.D.

3- (No 937): Handle fragment; Kimistene, Acropolis, found in 2005. pl. $1 / 3$.

Max. h $2.3 \mathrm{~cm}$., max. w $2.7 \mathrm{~cm}$., max. th $0.7 \mathrm{~cm}$

Light olive brown (2.5Y 5/6) glaze on exterior; reddish yellow (5YR 6/8), unslipped surface in interior. Hard and thin paste; very sparsely porous, fine, light red (2.5YR 7/6) fabric with some sand and lime inclusions. $10^{\text {th }}-11^{\text {th }}$ cent. A.D.

4- ( $\left.\mathrm{N}^{\circ} 1245\right)$ : Body fragment; Kimistene, Acropolis, western slope of the temple, surface find, found in 2005 .

pl. $22 / 4$.

Max. h $2.7 \mathrm{~cm}$., max. w $2.5 \mathrm{~cm}$., max. th $0.6 \mathrm{~cm}$.

Reddish yellow (5YR 6/6), unslipped surface on exterior; brownish yellow (10YR 6/6) glaze on interior. Hard and thin paste; non-porous, fine, reddish yellow (5YR 6/6) fabric with some tiny lime inclusions.

5- (No 895): Body fragment; Kimistene, Acropolis, southern slope, underground cave, surface find, found in 2005.

pl. $22 / 5$.

Max. h $2.6 \mathrm{~cm}$., max. w $3.1 \mathrm{~cm}$., max. th $0.5 \mathrm{~cm}$.

Dark olive brown (2.5Y 3/3) glaze on exterior; red (2.5YR 4/6), unslipped surface in interior. Hard and thin paste; very sparsely porous, fine, light red (2.5YR 6/6) fabric with occasional tiny lime and sand inclusions.

6- $\left(\mathrm{N}^{\circ} 112\right)$ : Body fragment; Bath A, room 10, found in 2007 .

pl. $1 / 6$.

Max. h $3.2 \mathrm{~cm}$., max. w $3.6 \mathrm{~cm}$., max. th $0.6 \mathrm{~cm}$

Strong brown (7.5YR 5/6) glaze on exterior; light red (2.5YR 6/6), unslipped surface in interior. Hard and thin paste; very sparsely porous, fine, light red (2.5YR 6/6) fabric with some tiny lime inclusions.

7- ( $\mathrm{N}^{\mathrm{o}} 243$ ): Body fragment ${ }^{57}$; western tomb, surface find, found in 2007.

pl. $22 / 7$.

Max. h 4.0 cm., max. w $4.8 \mathrm{~cm}$., max. th $0.6 \mathrm{~cm}$.

Reddish brown (2.5YR 4/3) glaze on exterior; light olive brown (2.5Y 5/4) glaze on interior. Hard and thin paste; very sparsely porous, fine, light red (2.5YR 6/8) fabric with some lime and rare sand inclusions.

55) Finds from Pompeiopolis: Summerer, von Kienlin and Herdt 2010: 424; Okçular Kale near Cide: Düring, Şerifoğlu and Glatz 2012: 243; monochrome glazed wares dated to $11^{\text {th }}$ cent. A.D. from Hamamtepe Höyük in the chora of Pontic Comana: Erciyas, Sökmen and Kocabiylk 2011: 124, fig. 12 and 113. Other finds: Avkat (ancient Euchaita): Vroom 2008: 21; Hayes 1992: 18-29; and Vroom 2006: 165-166. Recent Turkish excavations at Kurul Citadel in Ordu provided some Middle Byzantine pottery which is being exhibited at the Museum of Ordu and remains as unpublished. Turkish local museums at the Black Sea area have very few Middle Byzantine pottery in their collections.

56) Similar examples: Vroom 2006: 164; and Hayes 1992: fig. 4.

57) A similar body fragment: Von Wartburg 2007: 427, fig. 5, $n^{\circ} 1$. 

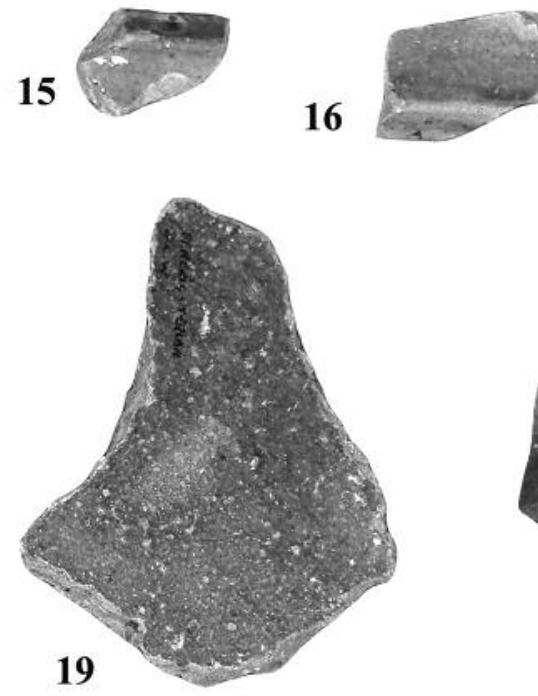

17

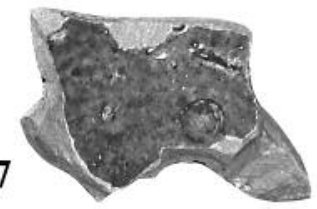

18
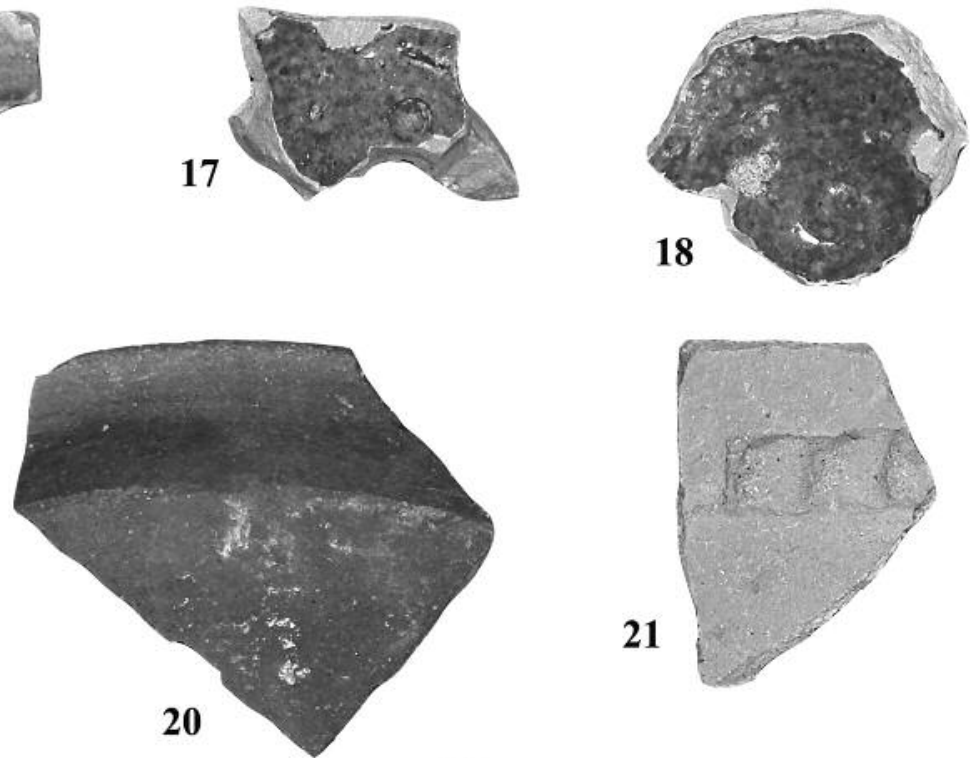

21

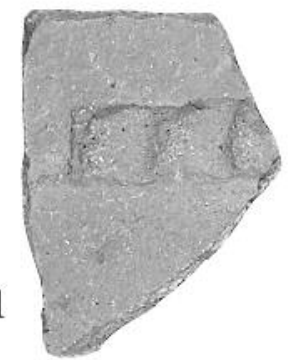

23

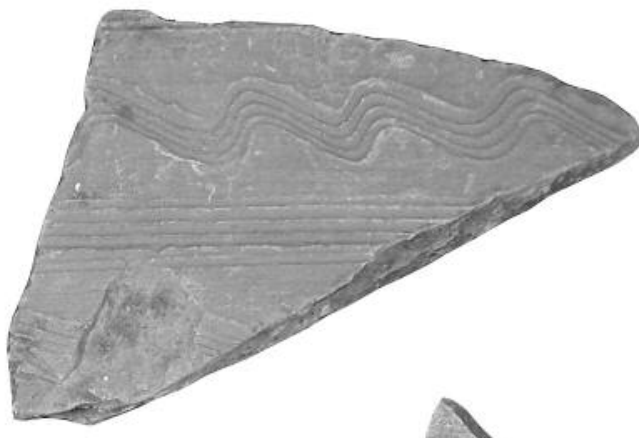

22

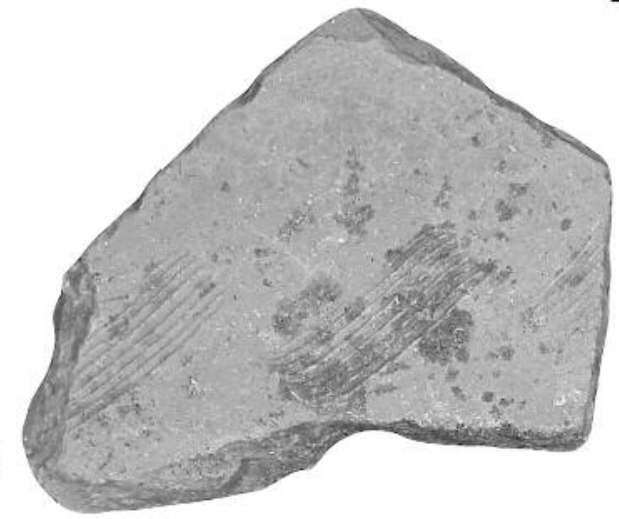

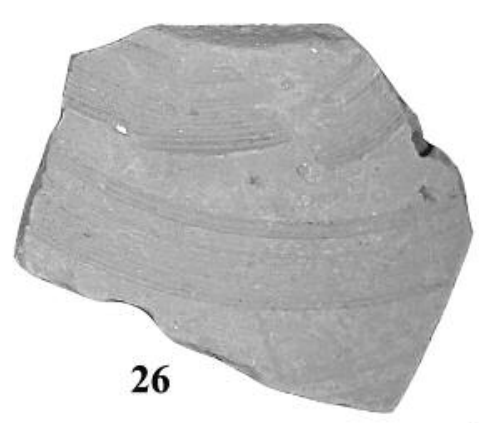

27
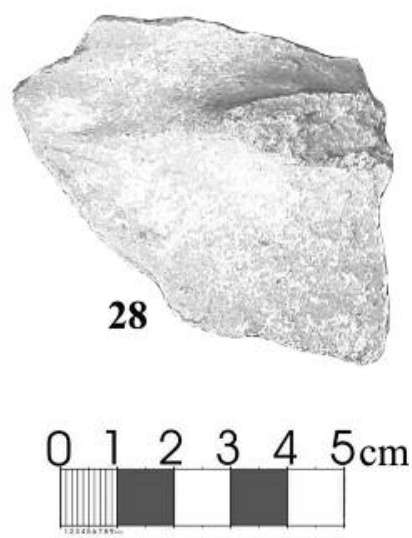

Fig. 13 : Comparative Middle Byzantine surface ceramic sherds from Paphlagonian and Pontic sites at the Pottery Collection of the British Institute of Archaeology at Ankara from a field survey in 1963: $n^{\text {os }}$ 15-18: Akdeğirmen in Zara, Sivas; $n^{0}$ 19: Pekeriç (today Çadırkaya) in Tercan, Erzincan; $\mathbf{n}^{\text {os }}$ 20-21:

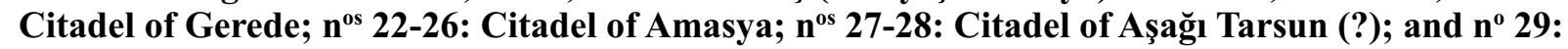
Pekeriç (today Çadırkaya) in Tercan, Erzincan. 


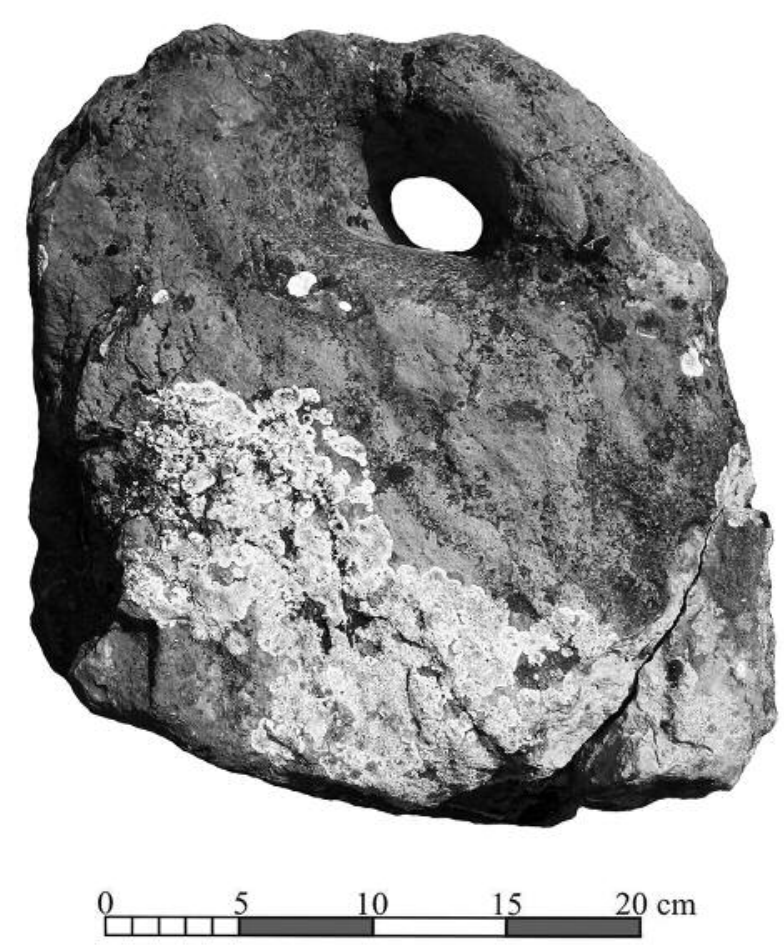

Fig. 14 : A press weight from Kimistene, from an area between Necropolis I and II. W $63 \mathrm{~cm}$; $170 \mathrm{~cm}$; th $42 \mathrm{~cm}$; and $\mathrm{d}$ of the hole $10 \mathrm{~cm}$. Local limestone.

8- (No 918): Body fragment ${ }^{58}$; Kimistene, Acropolis, southeastern slope, on the way to the cistern, on a rocky slope, surface find, found in 2005.

pl. $22 / 8$.

Max. h $4.5 \mathrm{~cm}$., max. w $3.5 \mathrm{~cm}$., max. th $0.4 \mathrm{~cm}$.

Pink (5YR 8/4), unslipped surface on exterior; yellow (10YR 7/8) glaze on interior. Hard and thin paste; very sparsely porous, fine, reddish yellow (5YR 7/8) fabric with visible inclusions.

9- ( $\left.\mathrm{N}^{\mathrm{o}} 178\right)$ : Body fragment ${ }^{59} ;$ domus, room 5 , found in 2007.

pl. $22 / 9$.

Max. h $4.6 \mathrm{~cm}$., max. w $3.4 \mathrm{~cm}$., max. th $0.6 \mathrm{~cm}$.

Undecorated and glazed interior surface.

Light olive brown (2.5Y 5/4) glaze both on exterior and interior. Hard and thin paste; non-porous, fine, red (2.5YR 5/8) fabric with lime and small grit inclusions.

\author{
Unglazed Vessels \\ (pls. 1-4, nos 10-55; pl. 22, $\mathrm{n}^{\text {os }} 25-31$ )
}

These utilitarian fragments include mostly rim fragments of undecorated jars and juglets. The use of hollow pottery vessels, such as redundant amphorae, to reduce the weight of vaults is well known in Middle Byzantine architecture. Indeed, some large joining fragments of table amphorae or water jugs, found in clusters in the debris, could be evidence of this practice in southwestern Paphlagonia.

\section{Open Forms \\ (pls. 1-2, nos 10-24; pl. 22, $\mathrm{n}^{\text {os } 25-29)}$ \\ Rim Fragments of Coarse Dishes \\ (pls. 1-2, nos 10-23)}

15 fragments belong to unglazed hemispherical (pls. $1-2, \mathrm{n}^{\text {os }} 18$ and 23) or everted rim bowls or dishes (pls. 1$2, \mathrm{n}^{\text {os }} 12-15$ and 19-22) ${ }^{60}$. Some vessels have a rounded and wide lip. Mostly they are large, thick-walled dishes with an incurved rim rim diameter of which ranges from 9.2 to $32.8 \mathrm{~cm}$. Examples vary considerably in size. Because of the wide rim diameters they may be deep dishes for food service. Experiments have confirmed the inadequacy of the bowls for consumption ${ }^{61}$. Some examples have a thin slip on interior and exterior's upper part. $\mathrm{N}^{\mathrm{os}}$ 19-23 on pl. 2 are shallow dishes.

10- (No 1129): Rim fragment; Kimistene, Acropolis, found in 2005 .

pl. 1/10.

Max. h $2.2 \mathrm{~cm}$., d of rim $9.2 \mathrm{~cm}$., max. w $4.5 \mathrm{~cm}$., max. th $0.8 \mathrm{~cm}$.

Brown (7.5YR 5/4), unslipped surface both on exterior and interior. Average hardness; non-porous, fine, yellowish red (5YR 4/6) fabric with occasional tiny lime and rare sand inclusions.

Late $9^{\text {th }}$-early $10^{\text {th }}$ cent. A.D.

11- ( $\mathrm{N}^{\mathrm{1}}$ 1250): Rim fragment; Kimistene, western slope of the temenos, found in 2005.

pl. 1/11.

Max. h $2.1 \mathrm{~cm}$., d of rim $14.2 \mathrm{~cm}$., max. w $3.2 \mathrm{~cm}$, max. th $0.7 \mathrm{~cm}$.

Dark grey (2.5Y 4/1), unslipped surface both on exterior and interior. Average hardness; very sparsely porous, dark grey $(2.5 \mathrm{Y} 4 / 1)$ fabric with frequent lime and medium grit inclusions.

Late $10^{\text {th }}-11^{\text {th }}$ cent. A.D.

58) Similar sherds from Kaman-Kalehöyük and elsewhere: Vroom 2006: 165, $\mathrm{n}^{\circ}$ 2a-b; and D'Amico 2007: 223 , fig. 3.

59) Similar Middle and Late Byzantine pottery finds from the Agora of Smyrna: Doğer 2007: 103, pl. X, fig. f; and Doğer 2015 : $58, \mathrm{pl}$. II, $\mathrm{n}^{\text {os }} 5,7$ and 12 .

60) Similar hemispherical forms: Vionis et al. 2010: 435, figs. 7a-b.

61) Vionis et al. 2010: 451. It is also noted that some of the plain carinated dishes preserved repair holes; perhaps these open vessels were considered valuable and worth repairing, because they had multiple functions, such as food preparation, serving, and consumption. This pattern has also been observed in southwestern Paphlagonia. 

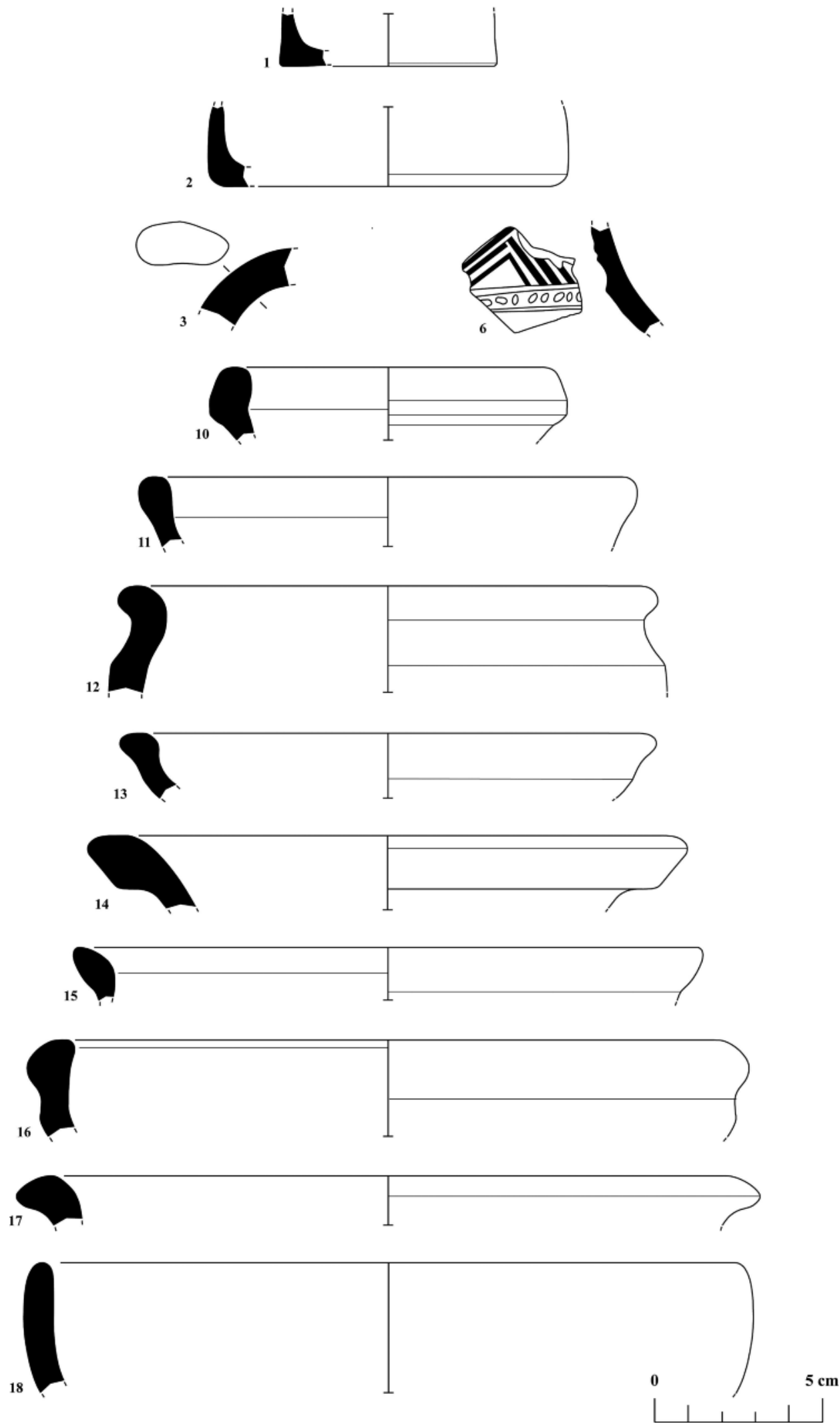

Pl. 1 : Nos $^{\text {1-18 }}$ : Tableware; $n^{\text {os }}$ 1-6: Glazed vessels; and $n^{\text {os }} 10-18$ : Rim fragments of coarse dishes. 
12- ( $\left.\mathrm{N}^{\circ} 1205\right)$ : Rim fragment; Kimistene, summit of the Acropolis, southern slope, found in 2005.

pl. 1/12.

Max. h $3.2 \mathrm{~cm}$. , d of rim $15.0 \mathrm{~cm}$., max. w $4.1 \mathrm{~cm}$., max. th $1.0 \mathrm{~cm}$.

Interior rim is burnished.

Dark grey (10YR 4/1) slip on exterior; black (10YR 2/1) slip on interior rim. Hard paste; very sparsely porous, fine, brown (7.5YR 5/4) fabric with frequent lime and medium grit inclusions.

$9^{\text {th }}-10^{\text {th }}$ cent. A.D.

13- ( $\mathrm{N}^{\circ}$ 1207): Rim fragment; Kimistene, summit of the Acropolis, southern slope, found in 2005.

pl. $1 / 13$.

Max. h $1.9 \mathrm{~cm}$. , d of rim $15.0 \mathrm{~cm}$., max. w $4.5 \mathrm{~cm}$., max. th $0.7 \mathrm{~cm}$.

Carbon traces is visible on the surface. Very pale brown (10YR 7/3), unslipped surface both on exterior and interior. Hard and thin paste; non-porous, very pale brown (10YR 7/3) fabric with some tiny lime inclusions.

$9^{\text {th }}-10^{\text {th }}$ cent. A.D.

14- (No 492): Rim fragment; Kimistene, Acropolis, southern slope, just below the summit, towards Deresemail creek, found in 2005 .

pl. 1/14.

Max. h $2.2 \mathrm{~cm}$., d of rim $17.6 \mathrm{~cm}$., max. w $4.2 \mathrm{~cm}$., $\max$. th $0.8 \mathrm{~cm}$.

Reddish yellow (5YR 6/6), unslipped surface both on exterior and interior. Hard paste; very sparsely porous, reddish yellow (5YR 6/6) fabric with occasional sand and tiny lime inclusions.

$9^{\text {th }}-10^{\text {th }}$ cent. A.D.

15- (No 804): Rim fragment; Kimistene, summit of the Acropolis, western slope, found in 2005.

pl. $\mathbf{1} / \mathbf{1 5}$.

Max. h $1.6 \mathrm{~cm}$., d of rim $18.4 \mathrm{~cm}$., max. w $2.7 \mathrm{~cm}$., $\max$. th $0.5 \mathrm{~cm}$.

Pale brown (10YR 6/3), unslipped surface both on exterior and interior. Hard paste; very sparsely porous, fine, light yellowish brown (10YR 6/4) fabric with some lime and sand inclusions.

$9^{\text {th }}-10^{\text {th }}$ cent. A.D.

16- ( $\mathrm{N}^{\circ}$ 521): Rim fragment; Kimistene, Acropolis, southern slope, just below the summit, towards Deresemail creek, found in 2005 .

pl. $1 / 16$.

Max. h 2.9 cm., d of rim $19.4 \mathrm{~cm}$., max. w $4.3 \mathrm{~cm}$., max. th $0.9 \mathrm{~cm}$.

Exterior is burnished. A groove is under the thickened rim on the exterior.

Light brown (7.5YR 6/4) slip on exterior; light red (2.5YR 6/6), unslipped surface in interior. Hard paste; non-porous, light reddish brown (2.5YR 6/4) and grey (5YR 5/1) mottled fabric with some tiny lime inclusions.

$9^{\text {th }}$ cent. A.D.
17- ( No 1454): Rim fragment; Kimistene, Acropolis, found in 2005 .

pl. 1/17.

Max. h $1.5 \mathrm{~cm}$., d of rim $20.2 \mathrm{~cm}$., max. w $6.4 \mathrm{~cm}$., max. th $0.9 \mathrm{~cm}$.

Pale brown (10YR 6/3) slip both on exterior and interior. Hard paste; very sparsely porous, fine, brown (10YR 5/3) fabric with some lime and small grit inclusions.

Late $10^{\text {th }}$-early $11^{\text {th }}$ cent. A.D.

18- (No 871): Rim fragment; Kimistene, Acropolis, southern slope, underground cave, surface find, found in 2005.

pl. 1/18.

Max. h $3.9 \mathrm{~cm}$., d of rim $20.6 \mathrm{~cm}$., max. w $6.1 \mathrm{~cm}$., max. th $0.9 \mathrm{~cm}$.

Exterior is burnished.

Pink (7.5YR 8/3) slip on exterior; reddish yellow (5YR 6/6), unslipped surface in interior. Hard and thin paste; sparsely porous, reddish yellow (5YR 6/6) and grey (Gley $15 / \mathrm{N})$ mottled fabric with occasional lime inclusions.

$9^{\text {th }}$ cent. A.D.

19- (No 1456): Rim fragment; Kimistene, Acropolis, found in 2005 .

pl. 2/19.

Max. h $2.4 \mathrm{~cm}$. , d of rim $25.4 \mathrm{~cm}$., max. w $4.4 \mathrm{~cm}$., max. th $1.1 \mathrm{~cm}$.

Greyish brown (10YR 5/2), unslipped surface both on exterior and interior. Soft paste; non-porous, brown (10YR 5/3) and dark greyish brown (10YR 4/2) mottled fabric with frequent tiny lime inclusions.

Late $10^{\text {th }}$-early $11^{\text {th }}$ cent. A.D.

20- (No 493): Rim fragment; Kimistene, Acropolis, southern slope, just below the summit, towards Deresemail creek, found in 2005 .

pl. $2 / 20$.

Max. h $3.1 \mathrm{~cm}$., d of rim $25.6 \mathrm{~cm}$., max. w $5.6 \mathrm{~cm}$., max. th $1.0 \mathrm{~cm}$.

Light red (2.5YR 6/6), unslipped surface both on exterior and interior. Hard paste; non-porous, fine, light red (2.5YR 6/6) fabric with occasional tiny lime inclusions.

$10^{\text {th }}$ cent. A.D.

21- ( ${ }^{\circ}$ 928): Rim fragment; Kimistene, Acropolis, found in 2005 .

pl. $2 / 21$.

Max. h $2.6 \mathrm{~cm}$., d of rim $28.6 \mathrm{~cm}$., max. w $6.3 \mathrm{~cm}$., $\max$. th $1.1 \mathrm{~cm}$.

Light brown (7.5YR 6/3), unslipped surface both on exterior and interior. Average hardness; non-porous, light brown (7.5YR 6/3) and light brownish grey (10YR 6/2) mottled fabric with frequent lime and small grit inclusions.

Late $10^{\text {th }}$-early $11^{\text {th }}$ cent. A.D. 
22- ( $\mathrm{N}^{\circ}$ 824): Rim fragment; Kimistene, summit of the Acropolis, western slope, found in 2005.

pl. $2 / 22$.

Max. h $3.4 \mathrm{~cm}$., d of rim $28.8 \mathrm{~cm}$., max. w $5.7 \mathrm{~cm}$., $\max$. th $1.0 \mathrm{~cm}$.

It is a deep plate form with a plain rim$^{62}$. All of surface is burnished. Vertical burnished decoration.

Brown (10YR 5/3) slip both on exterior and interior; greyish brown (10YR 5/2) paint on exterior slip. Hard paste; very sparsely porous, fine, brown (10YR 5/3) fabric with infrequent tiny lime inclusions.

$10^{\text {th }}$ cent. A.D.

23- ( $\left.\mathrm{N}^{\circ} 1270\right)$ : Rim fragment; Kimistene, Necropolis I, found in 2005 .

pl. $2 / 23$.

Max. h $4.4 \mathrm{~cm}$., d of rim $32.8 \mathrm{~cm}$., max. w $9.1 \mathrm{~cm}$., $\max$. th $1.2 \mathrm{~cm}$.

Very pale brown (10YR 7/3) slip both on exterior and interior. Hard paste; non-porous, dark greyish brown (10YR 4/2) and brown (7.5YR 5/4) mottled fabric with some tiny lime inclusions.

Late $10^{\text {th }}$-early $10^{\text {th }}$ cent. A.D.

\section{A Base Fragment of Open Forms}

$$
\text { (pl. 2, no 24) }
$$

It has a ring and large base as well as a plain tondo.

24- ( $\mathrm{N}^{\circ}$ 628): Base fragment; Kimistene, Acropolis, found in 2005 .

pl. $2 / 24$.

Max. h $3.2 \mathrm{~cm}$., d of rim $16.4 \mathrm{~cm}$., max. w $8.8 \mathrm{~cm}$., max. th $0.9 \mathrm{~cm}$.

Light reddish brown (2.5YR 6/4) slip both on exterior and interior. Average hardness; non-porous, reddish brown (2.5YR 5/4) fabric with occasional quartz and tiny lime inclusions.

\section{A Handle Fragment of Open Forms (pl. 22, $\left.\mathrm{n}^{\circ} 25\right)$}

Vertical handle of a small bowl. Exterior is burnished.

25- (№ 459): Handle fragment; Kimistene, Acropolis, southern slope, just below the summit, towards Deresemail creek, found in 2005 .

pl. $22 / 25$.

Max. h $2.7 \mathrm{~cm}$., max. w $3.8 \mathrm{~cm}$., $\max$. th $0.5 \mathrm{~cm}$.

Light red (2.5YR 6/6) shiny slip both on exterior and interior. Average hardness, thin paste; non-porous, light red (2.5YR 6/6) and dark grey (Gley $14 / \mathrm{N})$ mottled fabric with occasional tiny lime inclusions.

\section{Body Fragments of Open Forms \\ (pl. 22, nos 26-29)}

Undecorated body sherds except $\mathrm{n}^{\circ} 27$ on pl. 22 which has bands on interior.

26- (No 1312): Body fragment; Kimistene, Acropolis, southern slope, found in 2005.

pl. $22 / 26$.

Max. h $2.5 \mathrm{~cm}$., max. w $3.5 \mathrm{~cm}$., max. th $0.7 \mathrm{~cm}$.

All of the surface is blackened. It is burnished in interior

Reddish brown (5YR 5/4) slip on exterior; reddish brown (5YR 4/3) slip on interior. Average hardness; very sparsely porous, dark reddish brown (5YR 3/2) fabric with some lime and medium grit inclusions.

27- (No 1244): Body fragment; Kimistene, Acropolis, southern slope, just below the summit, towards Deresemail creek, found in 2005.

pl. $22 / 27$.

Max. h $3.5 \mathrm{~cm}$., max. w $6.0 \mathrm{~cm}$., $\max$. th $1.2 \mathrm{~cm}$.

Reddish yellow (5YR 6/6), smoothed unslipped surface both on exterior and interior. Average hardness, thin paste; non-porous, yellowish red (5YR 5/6) and light brownish grey (10YR 6/2) mottled fabric with some tiny lime and small grit inclusions.

28- ( $\mathrm{N}^{\circ}$ 666): Body fragment; Kimistene, cistern, eastern slope, found 2005.

pl. 22/28.

Max. h $6.0 \mathrm{~cm} ., \max . w 7.1 \mathrm{~cm} ., \max$. th $1.2 \mathrm{~cm}$.

Greyish brown (10YR 5/2) slip both on exterior and interior. Hard paste; very sparsely porous, fine, greyish brown (10YR 5/2) fabric with some tiny lime inclusions.

29- (No 727): Body fragment; Kimistene, Acropolis, temple's terrace, illegally excavated area under the temple's podium, surface find, found in 2005 .

pl. $22 / 29$.

Max. h $7.5 \mathrm{~cm}$., max. w $5.0 \mathrm{~cm}$., max. th $1.1 \mathrm{~cm}$.

All of the surface is blackened and vertically burnished.

Light reddish brown (7.5YR 6/4) slip both on exterior and interior. Hard paste; non-porous, grey (7.5YR 5/1) fabric with frequent sand and rare lime inclusions.

\section{Rim Fragments of Closed Forms}

(pls. 2-4, nos 32-55; pl. 22, nos $30-31$ )

Closed vessels identified mostly as table jugs or small globular vessels with everted or downturned rims comprise majority of the total tablewares. They were commonly used for drinking or holding liquids, such as 

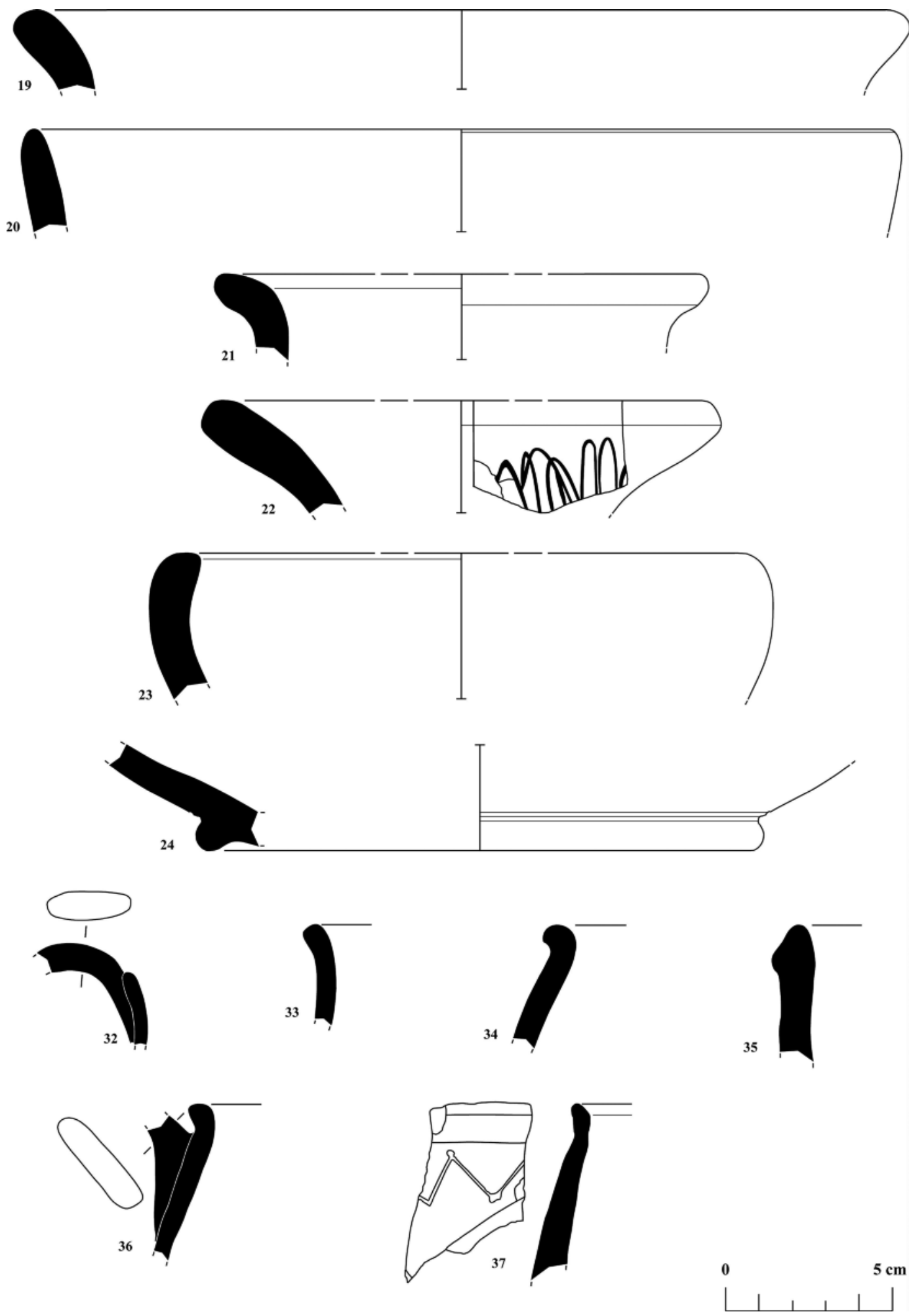

Pl. 2 : Nos 19-37 : Tableware; $\mathbf{n}^{\text {os }}$ 19-23: Rim fragments of coarse dishes; $\mathbf{n}^{\circ}$ 24: A base fragment of open forms; and $n^{\text {os }}$ 32-37: Rim fragments of closed forms. 
water and wine. They were porous, so that these liquids shall keep $\operatorname{cool}^{63}$. Especially jug fragments make up a significant proportion of Kimistene's ceramic assemblage which was probably used for the water storage. Some jars are without neck (pls. 2-3, $\mathrm{n}^{\text {os }} 34,36-37$ and 44 ) or a wide rim. Some of them are rounded lip jugs or small amphorae without any decoration. In some cases their short flaring necks end in a slightly everted, rounded rim without any angle between rim and shoulder ${ }^{64}$. These closed vessels are generally made of a brown (7.5YR 5/4, 5/2, 6/4, 10YR 6/4, 5/3, 7/3), reddish-brown (5YR $5 / 4)$, reddish-yellow (5YR 6/6, 7.5 YR 6/6) and red (2.5YR $5 / 6,5 / 8,6 / 6)$ fabric with a moderately rough feel at the break and hackly fracture.

30- ( $\mathrm{N}^{\circ}$ 491): Rim fragment; Kimistene, Acropolis, southern slope, just below the summit, towards Deresemail creek, found in 2005.

pl. $22 / 30$.

Max. h $4.2 \mathrm{~cm}$., max. w $4.5 \mathrm{~cm}$., max. th $1.0 \mathrm{~cm}$.

Pink (7.5YR 7/3), unslipped surface both on exterior and interior. Hard paste; non-porous, fine, light brown (7.5YR 6/4) fabric with some tiny lime and sand as well as rare quartz inclusions.

Late $9^{\text {th }}$-early $10^{\text {th }}$ cent. A.D.

31- ( $\mathrm{N}^{\mathrm{o}}$ 1182): Rim fragment; Kimistene, cistern, eastern slope, surface find, found 2005.

pl. $22 / 31$.

Max. h $4.0 \mathrm{~cm}$., max. w $3.5 \mathrm{~cm}$., max. th $0.5 \mathrm{~cm}$.

Brown (7.5YR 5/4), unslipped surface both on exterior and interior. Average hardness; sparsely porous, fine, light brown (10YR 6/4) fabric with occasional tiny lime and sand inclusions.

Late $10^{\text {th }}$-early $11^{\text {th }}$ cent. A.D.

32- ( $\left.\mathrm{N}^{\circ} 1123\right)$ : Rim fragment ${ }^{65}$; Kimistene, Acropolis, found in 2005 .

pl. $2 / 32$.

Max. h $3.0 \mathrm{~cm}$., max. w $3.3 \mathrm{~cm}$., max. th $0.5 \mathrm{~cm}$.

Its handle is attached to the rim.

Very pale brown (10YR 7/3), unslipped surface both on exterior and interior. Soft paste; very sparsely porous, very pale brown (10YR 7/3) fabric with some sand and lime inclusions.

Late $9^{\text {th }}$-early $10^{\text {th }}$ century.

33- ( $\mathrm{N}^{\circ}$ 1146): Rim fragment; Kimistene, Acropolis, southern slope, just below of the summit of Deresemail creek, found in 2005 .

Max. h $3.0 \mathrm{~cm}$., $\max$. w $2.5 \mathrm{~cm}$., $\max$. th $0.5 \mathrm{~cm}$.
Pale brown (10YR 6/3), unslipped surface on exterior; light brown (7.5YR 6/4), unslipped surface in interior. Average hardness; non-porous, light brown (7.5YR 6/4) fabric with occasional tiny lime and small grit inclusions.

Late $9^{\text {th }}$-early $10^{\text {th }}$ century.

34- ( $\mathrm{N}^{\circ}$ 382): Rim fragment; Kimistene, Acropolis, southern slope, just below the summit, towards Deresemail creek, found in 2005 .

pl. 2/34.

Max. h $3.7 \mathrm{~cm}$., max. w $4.2 \mathrm{~cm}$., max. th $0.7 \mathrm{~cm}$.

Light brown (7.5YR 6/4), unslipped surface on exterior; reddish yellow (5YR 6/6), unslipped surface in interior. Average hardness; very sparsely porous, reddish yellow (5YR 6/6) and dark reddish grey (5YR 4/2) mottled fabric with some tiny lime as well as rare mica and sand inclusions.

Late $9^{\text {th }}$-early $10^{\text {th }}$ century.

35- (No 634): Rim fragment; Kepez, cistern, surface find, found in 2005 .

pl. $2 / 35$.

Max. h $4.1 \mathrm{~cm}$., max. w $4.0 \mathrm{~cm}$., max. th $1.0 \mathrm{~cm}$.

Light red (2.5YR 6/6), unslipped surface both on exterior and interior. Hard paste; very sparsely porous, light red (2.5YR 6/6) and light red (2.5YR 6/4) mottled fabric with some tiny lime as well as rare small grit and quartz inclusions.

$9^{\text {th }}$ cent. A.D.

36- ( $\mathrm{N}^{\circ}$ 707): Rim fragment; Kimistene, Acropolis, temple's eastern slope, surface find, found in 2005.

pl. 2/36.

Max. h 4.7 cm., max. w $5.2 \mathrm{~cm}$., max. th $0.5 \mathrm{~cm}$.

Its handle is attached to the neck.

Light brown (7.5YR 6/3), unslipped surface on exterior; light reddish brown (5YR 6/4), unslipped surface in interior. Hard paste; very sparsely porous, fine, reddish yellow (5YR 6/6) fabric with infrequent tiny lime inclusions.

Late $9^{\text {th }}$-early $10^{\text {th }}$ century.

37- ( $\left.\mathrm{N}^{\circ} 600\right)$ : Rim fragment; Bath $\mathrm{A}$, room 10, found in 2007.

pl. $2 / 37$.

Max. h $5.3 \mathrm{~cm}$. , max. w $4.1 \mathrm{~cm}$., max. th $0.9 \mathrm{~cm}$.

Light brown (7.5YR 6/4) slip both on exterior and interior rim. Hard paste; non-porous, red (2.5YR 5/6) and dark grey $(7.5 \mathrm{YR} 4 / 1)$ mottled fabric with frequent tiny lime inclusions.

$9^{\text {th }}$ cent. A.D.

63) Vionis 2001: 84.

64) Similar examples: Vionis et al. 2010: 436, figs. 7c-f, $n^{\text {os }} 32-33$ and 45.

65) A similar rim profile and a handle of a jug from Amorium: Böhlendorf-Arslan 2012: 153, fig. 1.1 (late $8^{\text {th }}$-early $9^{\text {th }}$ cent. A.D.). 
38- (No 497): Rim fragment; Kimistene, Acropolis, southern slope, just below the summit, towards Deresemail creek, found in 2005 .

pl. $3 / 38$.

Max. h $4.2 \mathrm{~cm}$., d of rim $6.0 \mathrm{~cm}$., max. w $4.1 \mathrm{~cm}$., $\max$. th $1.0 \mathrm{~cm}$.

Reddish yellow (5YR 6/6), unslipped surface on exterior; light reddish brown (5YR 6/4), unslipped surface in interior. Hard paste; non-porous, fine, reddish yellow (5YR 6/6) fabric with occasional sand inclusions.

Early $10^{\text {th }}$ cent. A.D.

39- ( $\mathrm{N}^{\circ}$ 1477): Rim fragment; Kimistene, Acropolis, found in 2005 .

pl. 3/39.

Max. h $3.1 \mathrm{~cm}$., d of rim $8.2 \mathrm{~cm}$., max. w $3.2 \mathrm{~cm}$., $\max$. th $0.5 \mathrm{~cm}$.

Pink (7.5YR 7/4) slip both on exterior and interior rim. Hard paste; non-porous, fine, light brown (7.5YR $6 / 4$ ) fabric with frequent tiny lime and occasional sand inclusions.

Late $9^{\text {th }}$-early $10^{\text {th }}$ century.

40- ( $\mathrm{N}^{\circ}$ 661): Rim fragment; Kimistene, cistern, eastern slope, found in 2005.

pl. 3/40.

Max. h 2.9 cm., d of rim $8.8 \mathrm{~cm}$., max. w $3.1 \mathrm{~cm}$., $\max$. th $0.4 \mathrm{~cm}$.

Red (2.5YR 4/6) slip on exterior; red (2.5YR 5/6), unslipped surface in interior. Hard and thin paste; nonporous, fine, red $(2.5 \mathrm{YR} 4 / 6)$ fabric with occasional tiny lime and sand inclusions.

$9^{\text {th }}$ cent. A.D.

41- (No 981): Rim fragment; from the field surveys in Hadrianoupolis, surface find, found in 2005.

pl. 3/41.

Max. h $2.7 \mathrm{~cm}$., d of rim $8.6 \mathrm{~cm}$., max. w $4.6 \mathrm{~cm}$., $\max$. th $0.6 \mathrm{~cm}$.

Light brown (7.5YR 6/4), unslipped surface both on exterior and interior. Soft paste; non-porous, fine, brown (7.5YR 5/4) fabric with occasional mica inclusions.

Late $8^{\text {th }}$-early $9^{\text {th }}$ century.

42- ( $\mathrm{N}^{\circ} 1213$ ): Rim fragment; Kimistene, summit of the Acropolis, southern slope, found in 2005.

pl. $3 / 42$.

Max. h 5.4 cm., d of rim $9.0 \mathrm{~cm}$., max. w $7.5 \mathrm{~cm}$., $\max$. th $0.7 \mathrm{~cm}$.

Everted rim ${ }^{66}$ burnished both on exterior and interior.

Very dark grey (10YR 3/1) slip both on exterior and interior rim; very dark grey (Gley $13 / \mathrm{N}$ ), unslipped surface on lower interior. Hard paste; non-porous, red (2.5YR 4/6) fabric with frequent tiny lime and sand inclusions.

Late $9^{\text {th }}$ cent. A.D.
43- ( $\left.\mathrm{N}^{\mathrm{o}} 1103\right)$ : Rim fragment; domus, room 6, level 1 , found in 2007 .

pl. $3 / 43$.

Max. h $6.7 \mathrm{~cm}$., d of rim $9.3 \mathrm{~cm}$., max. w $6.7 \mathrm{~cm}$., $\max$. th $0.4 \mathrm{~cm}$.

Brown (7.5YR 5/3) slip both on exterior and interior rim; reddish brown (5YR 5/4), unslipped surface in interior. Hard paste; non-porous, reddish brown (5YR 5/4) and dark grey (5YR 4/1) mottled fabric with frequent tiny lime and some sand inclusions.

$9^{\text {th }}$ cent. A.D.

44- ( $\left.\mathrm{N}^{\circ} 1395\right)$ : Rim fragment; Kimistene, summit of the Acropolis, surface find, found in 2005.

pl. $3 / 44$.

Max. h $4.8 \mathrm{~cm}$., d of rim $10.2 \mathrm{~cm}$., max. w $5.7 \mathrm{~cm}$., $\max$. th $1.0 \mathrm{~cm}$.

Light reddish brown (5YR 6/4), unslipped surface on exterior; light brownish grey (2.5Y 6/2), unslipped surface in interior. Hard paste; very sparsely porous, reddish brown (5YR 5/4) and very dark grey (10YR 3/1) mottled fabric with frequent lime inclusions.

$10^{\text {th }}$ cent. A.D.

45- ( $\mathrm{N}^{\circ}$ 835): Rim fragment; Kimistene, cistern, eastern slope, found in 2005.

pl. $3 / 45$.

Max. h $2.1 \mathrm{~cm}$., d of base $10.4 \mathrm{~cm}$., max. w $4.8 \mathrm{~cm}$., $\max$. th $0.4 \mathrm{~cm}$.

Yellowish brown (10YR 5/4), unslipped surface both on exterior and interior. Hard paste; very sparsely porous, brown (10YR 5/3) fabric with frequent tiny lime and sand inclusions.

Late $9^{\text {th }}$-early $10^{\text {th }}$ century.

46- (No 990): Rim fragment; Kepez, found in 2005.

pl. 4/46.

Max. h $3.9 \mathrm{~cm}$., d of rim $11.0 \mathrm{~cm}$., max. w $6.9 \mathrm{~cm}$., max. th $0.6 \mathrm{~cm}$.

Light reddish brown (5YR 6/4), unslipped surface on exterior; reddish brown (5YR 5/4), unslipped surface in interior. Hard paste; very sparsely porous, reddish brown (5YR 5/4) fabric with some tiny lime and small grit inclusions.

Late $10^{\text {th }}-11^{\text {th }}$ cent. A.D.

47- (No 911): Rim fragment; Kimistene, Acropolis, southeastern slope, on the way to the cistern, on a rocky slope, surface find, found in 2005.

pl. $4 / 47$.

Max. h $4.6 \mathrm{~cm}$., d of rim $11.0 \mathrm{~cm}$., max. w $6.7 \mathrm{~cm}$., $\max$. th $0.7 \mathrm{~cm}$.

Light reddish brown (5YR 6/4) slip both on exterior and interior. Hard paste; non-porous, fine, reddish yellow (7.5YR 6/6) fabric with some tiny lime and small grit and rare quartz inclusions.

Late $9^{\text {th }}$-early $10^{\text {th }}$ century.

66) A similar rim profile from Cyprus: Gabrieli 2007: 402 and 406 , fig. 1 ( $12^{\text {th }}-14^{\text {th }}$ cent. A.D.). 

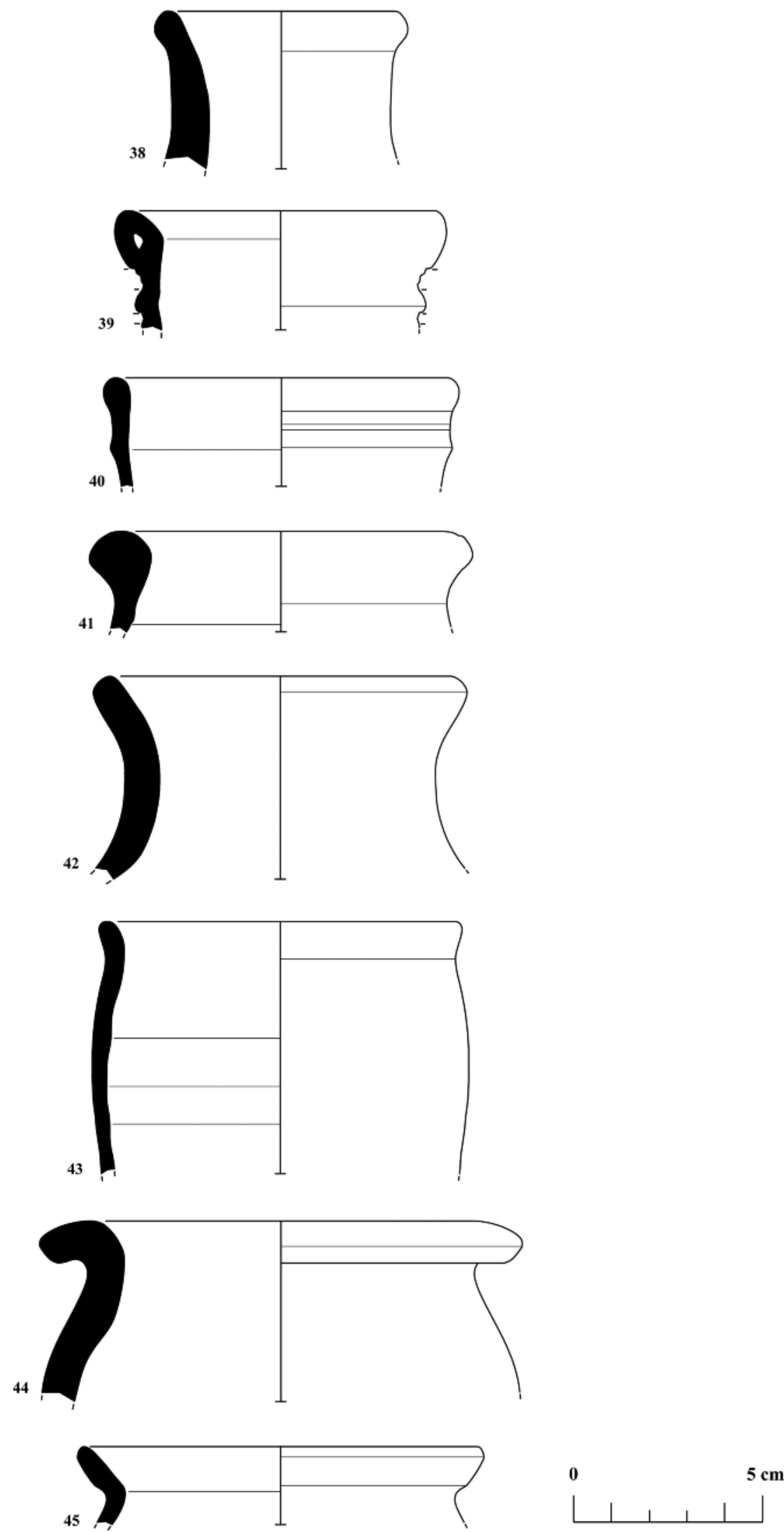

Pl. 3 : Nos 38-45 : Tableware, rim fragments of closed forms. 
48- (No 1463): Rim fragment; Acropolis, just below the summit, found in 2005 .

pl. $4 / 48$.

Max. h $2.0 \mathrm{~cm}$., d of rim $11.6 \mathrm{~cm}$., max. w $2.8 \mathrm{~cm}$., $\max$. th $0.7 \mathrm{~cm}$.

Greyish brown (10YR 5/2), unslipped surface both on exterior and interior. Hard paste; non-porous, very dark grey (10YR 3/1) fabric with frequent tiny lime inclusions.

Late $10^{\text {th }}$-early $11^{\text {th }}$ cent. A.D.

49- ( $\mathrm{N}^{\circ}$ 938): Rim fragment; Kimistene, Acropolis, found in 2005 .

pl. $4 / 49$.

Max. h $3.2 \mathrm{~cm}$., d of rim $12.4 \mathrm{~cm}$., max. w $5.0 \mathrm{~cm}$., max. th $0.5 \mathrm{~cm}$.

Reddish yellow (5YR 6/6), unslipped surface both on exterior and interior. Hard paste; non-porous, fine, red (2.5YR 5/6) fabric with occasional tiny lime and sand inclusions.

Late $9^{\text {th }}$-early $10^{\text {th }}$ century.

50- ( $\mathrm{N}^{\circ}$ 1276): Rim fragment; Kimistene, Necropolis I, found in 2005 .

pl. $4 / 50$.

Max. h 2.7 cm., d of rim 12.4 cm., max. w $3.9 \mathrm{~cm}$., $\max$. th $0.7 \mathrm{~cm}$.

Reddish yellow (5YR 6/6) slip both on exterior and interior rim. Soft paste; non-porous, fine, red $(2.5 \mathrm{YR}$ $5 / 8$ ) fabric with occasional lime and small grit inclusions.

$9^{\text {th }}$ cent. A.D.

51- (No 954): Rim fragment ${ }^{67}$; Kimistene, Acropolis, found in 2005 .

pl. $4 / 51$.

Max. h $2.0 \mathrm{~cm}$., d of rim $12.6 \mathrm{~cm}$., max. w $3.5 \mathrm{~cm}$., $\max$. th $0.5 \mathrm{~cm}$.

Slightly everted and thickened rim.

Light brown (7.5YR 6/4), unslipped surface both on exterior and interior. Hard paste; non-porous, fine, brown (7.5YR 5/2) fabric with occasional tiny lime and rare quartz inclusions.

$9^{\text {th }}$ cent. A.D.

52- (No 1096): Rim fragment; Kepez, found in 2005. pl. $4 / 52$.

Max. h $2.1 \mathrm{~cm}$., d of rim $13.0 \mathrm{~cm}$., max. w $4.2 \mathrm{~cm}$., $\max$. th $0.5 \mathrm{~cm}$.

Light reddish brown (5YR 6/4), unslipped surface both on exterior and interior. Soft paste; non-porous, fine, red (2.5YR 5/6) fabric with some mica and tiny lime inclusions.

Late $10^{\text {th }}$-early $11^{\text {th }}$ cent. A.D.

53- ( $\mathrm{N}^{\circ}$ 457): Rim fragment; Kimistene, Acropolis, southern slope, just below the summit, towards Deresemail creek, found in 2005.

pl. $4 / 53$.

Max. h $1.3 \mathrm{~cm}$., d of rim $15.4 \mathrm{~cm}$., max. w $5.9 \mathrm{~cm}$., max. th $0.6 \mathrm{~cm}$.

Very dark greyish brown (10YR 3/2), unslipped surface both on exterior and interior. Average hardness; very sparsely porous, fine, very dark grey (10YR 3/1) fabric with frequent tiny lime and occasional small grit inclusions.

Late $10^{\text {th }}$-early $11^{\text {th }}$ cent. A.D.

54- ( $\mathrm{N}^{\circ}$ 498): Rim fragment; Kimistene, Acropolis, southern slope, just below the summit, towards Deresemail creek, found in 2005.

pl. $4 / 54$.

Max. h $2.7 \mathrm{~cm}$., d of rim $16.0 \mathrm{~cm}$., max. w $3.4 \mathrm{~cm}$., max. th $0.8 \mathrm{~cm}$.

Interior surface is burnished.

Light brownish grey (10YR 6/2), unslipped surface on exterior; light brown (7.5YR 6/3) slip on interior. Hard paste; very sparsely porous, pinkish grey (7.5YR $6 / 2$ ) fabric with frequent tiny lime and rare grog inclusions.

Late $10^{\text {th }}$-early $11^{\text {th }}$ cent. A.D.

55- ( $\mathrm{N}^{\circ}$ 405): Rim fragment; Kimistene, Acropolis, eastern, lowest slope, found in 2005 .

pl. $4 / 55$.

Max. h $2.8 \mathrm{~cm}$., d of rim $14.8 \mathrm{~cm}$., max. w $6.0 \mathrm{~cm}$., $\max$. th $0.6 \mathrm{~cm}$.

Red (2.5YR 5/6), unslipped surface on exterior; light reddish brown (5YR 6/4), unslipped surface in interior. Hard paste; non-porous, fine, red (2.5YR 5/6) fabric with some lime inclusions.

$9^{\text {th }}$ cent. A.D.

\section{Kitchen Ware}

$$
\text { (pls. 5-8, nos 56-90; pl. 22, } \mathrm{n}^{\text {os }} \text { 64-75) }
$$

Even though it is sometimes difficult to identify correctly an individual kitchen ware type, large pitchers, pots, jars, and bulbous cooking pots are the most characteristic Middle Byzantine kitchen ware forms, and they are the most prevalent remaining shapes during these pe$\operatorname{riods}^{68}$. 

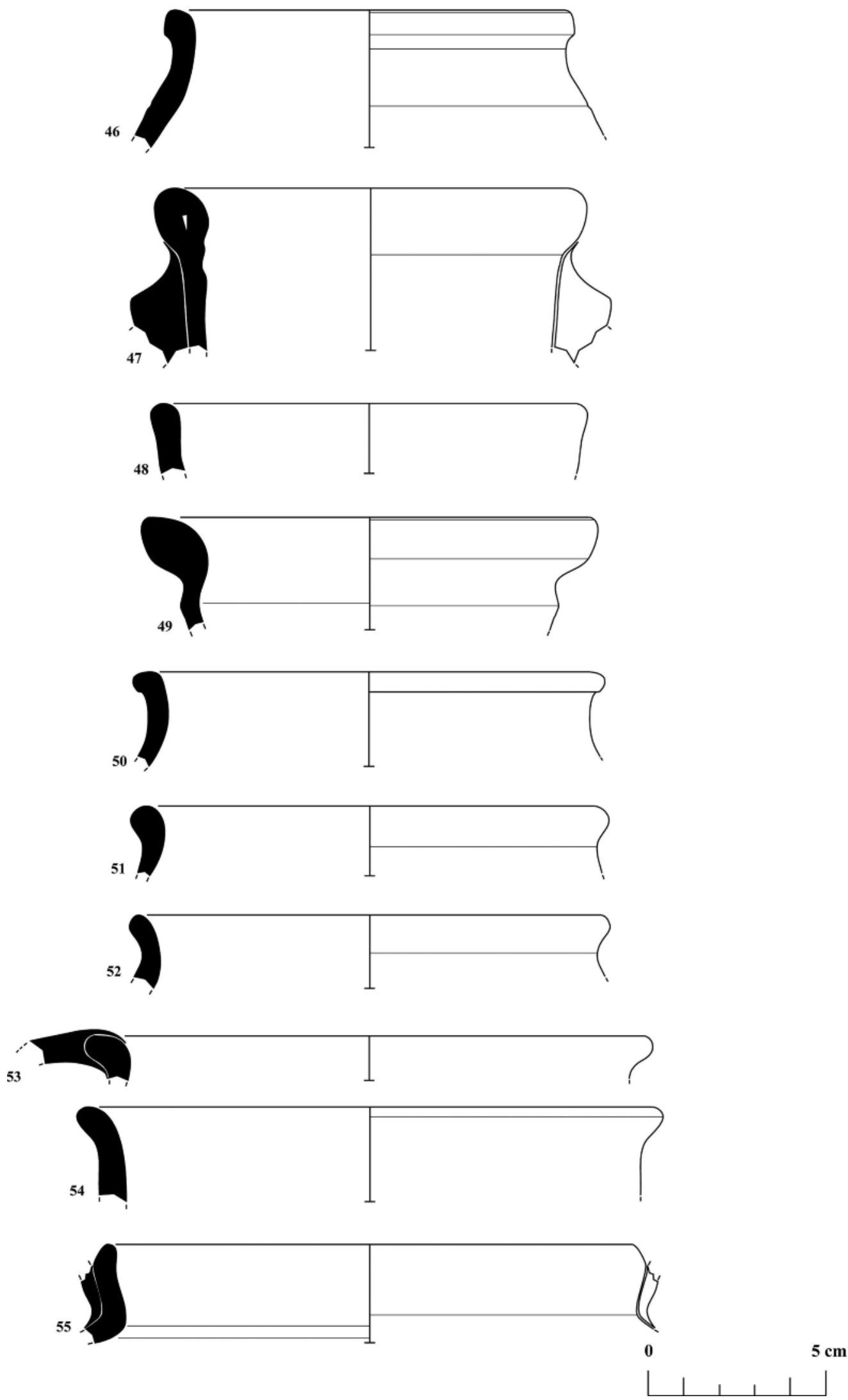

Pl. 4 : Nos 46-55 : Tableware, rim fragments of closed forms. 


\author{
Open Forms \\ (pls. 5-7, $\mathrm{n}^{\text {os }} 56-71 ;$ pl. 22, $\mathrm{n}^{\mathrm{o}} 64$ )
}

Casseroles (pl. 5, nos 56-62)

These are thin-walled cooking or baking dishes with rounded profiles, everted rims and straight, convergent upper bodies. Their rim is generally outflaring, and there is often an internal edge to place the rim. $\mathrm{N}^{\text {os }} 56$ and 58 on pl. 5 have a considerably thickened lip on the exterior that pulled nearly to a triangular section with a slightly concave upper face ${ }^{69}$.

56- ( $\mathrm{N}^{\mathrm{o}}$ 1152): Rim fragment; Kepez, cistern, found in 2005 .

pl. 5/56.

Max. h $2.5 \mathrm{~cm}$., d of rim $16.2 \mathrm{~cm}$., max. w $4.8 \mathrm{~cm}$., $\max$. th $0.7 \mathrm{~cm}$.

Light brown (7.5YR 6/4) slip both on exterior and interior. Soft paste; non-porous, reddish yellow (5YR 6/6) fabric with occasional sand as well as mica and tiny lime inclusions.

$$
9^{\text {th }} \text { cent. A.D. }
$$

57- (No 1263): Rim fragment; Kimistene, Necropolis I, surface find, found in 2005.

pl. $5 / 57$.

Max. h $2.6 \mathrm{~cm}$., d of rim $18.8 \mathrm{~cm}$., max. w $5.1 \mathrm{~cm}$., max. th $0.4 \mathrm{~cm}$.

Reddish brown (5YR 5/3), unslipped surface both on exterior and interior. Soft paste; non-porous, dark reddish grey (5YR 4/2) fabric with frequent mica and occasional lime inclusions.

Late $10^{\text {th }}$-early $11^{\text {th }}$ cent. A.D.

58- (No 1073): Rim fragment; Kepez, found in 2005. pl. $5 / 58$.

Max. h $5.2 \mathrm{~cm}$., d of rim $20.3 \mathrm{~cm}$., max. w $7.9 \mathrm{~cm}$., $\max$. th $0.8 \mathrm{~cm}$.

All of the surface is burnished.

Greyish brown (10YR 5/2) slip both on exterior and interior. Hard paste; very sparsely porous, very greyish brown (10YR 5/1) fabric with some sand and mica inclusions.

$9^{\text {th }}$ cent. A.D.

59- ( $\mathrm{N}^{\circ}$ 1391): Rim fragment; surface find from Örenarkası, found in 2005.

pl. $5 / 59$.

Max. h $4.4 \mathrm{~cm}$., d of rim $22.6 \mathrm{~cm}$., max. w $5.2 \mathrm{~cm}$., max. th $0.9 \mathrm{~cm}$.

Pale brown (10YR 6/3) slip both on exterior and interior. Soft paste; non-porous, light brownish grey (10YR $6 / 2$ ) and brown (7.5YR 5/3) mottled fabric with some tiny lime and medium grit inclusions.

Late $8^{\text {th }}$-early $9^{\text {th }}$ century.
60- (No 1080): Rim fragment; Kepez, found 2005.

pl. $5 / 60$.

Max. h $2.0 \mathrm{~cm}$., d of rim $23.4 \mathrm{~cm}$., max. w $3.5 \mathrm{~cm}$., $\max$. th $0.7 \mathrm{~cm}$.

Dark greyish brown (10YR 4/2), unslipped surface on exterior; brown (7.5YR 5/3), unslipped surface in interior. Average hardness; very sparsely porous, brown (7.5YR 5/3) fabric with frequent tiny lime inclusions.

Late $10^{\text {th }}$-early $11^{\text {th }}$ cent. A.D.

61- ( $\left.\mathrm{N}^{\circ} 1120\right)$ : Rim fragment; Kimistene, Acropolis, found in 2005 .

pl. $5 / 61$.

Max. h $2.8 \mathrm{~cm}$., d of rim $28.8 \mathrm{~cm}$., max. w $8.2 \mathrm{~cm}$., $\max$. th $1.6 \mathrm{~cm}$.

All of the surface is burnished. It is attached to a vertical handle.

Greyish brown (10YR 5/2) slip both on exterior and interior rim. Greyish brown (2.5Y 5/2), unslipped surface under the handle. Hard paste; very sparsely porous, fine, greyish brown (10YR 5/2) fabric with frequent lime inclusions.

$10^{\text {th }}$ cent. A.D.

62- ( $\left.{ }^{\circ} 120\right)$ : Rim fragment; Kepez, found in 2005.

pl. 5/62.

Max. h $3.0 \mathrm{~cm}$., d of rim $29.4 \mathrm{~cm}$., max. w $5.5 \mathrm{~cm}$., $\max$. th $0.7 \mathrm{~cm}$.

All of the surface is blackened and micaceous.

Very dark grey (2.5Y 3/1), unslipped surface both on exterior and interior. Hard paste; non-porous, dark grey $(2.5 \mathrm{Y} 4 / 1)$ fabric with some tiny lime and medium grit inclusions.

Late $10^{\text {th }}$-early $11^{\text {th }}$ cent. A.D.

$$
\begin{gathered}
\text { Basin/Deep Bowl } \\
\text { (pls. 5-7, } \mathrm{n}^{\text {os }} \text { 63-71; pl. 22, } \mathrm{n}^{\circ} \text { 64) }
\end{gathered}
$$

Nine sherds belong to a certain large basin form with a slightly or convex body which was probably a multifunctional vessel, used for pre-cooking preparations, cooking or food serving. This form exhibits slowly changing morphological details. All of the fragments are thick walled. These examples have mostly a diameter of 17 to $37.6 \mathrm{~cm}$. N ${ }^{\text {os }} 63,65,68-69$ and 71 on pls. 5-7 are of a large bowl form with downturned, everted, hatched or rolled out (pl. 6, $\mathrm{n}^{\circ}$ 70) rims. An example (pl. 6, $\mathrm{n}^{\circ}$ 66) has an incurved rim.

63- ( $\mathrm{N}^{\circ}$ 1366): Rim fragment; Kimistene, Acropolis, found in 2005 .

pl. 5/63.

Max. h $5.0 \mathrm{~cm}$., max. w $4.7 \mathrm{~cm}$., max. th $1.4 \mathrm{~cm}$

Pale brown (10YR 5/3) slip on exterior; light brownish grey (10YR 6/2), unslipped surface in interior. Average hardness; non-porous, fine, light brownish grey (10YR

69) A similar rim profile from Cyprus: Gabrieli $2008: 429$ and 437, fig. $7, n^{\circ}$ OI114 (13 ${ }^{\text {th }}-14^{\text {th }}$ cent. A.D.). 

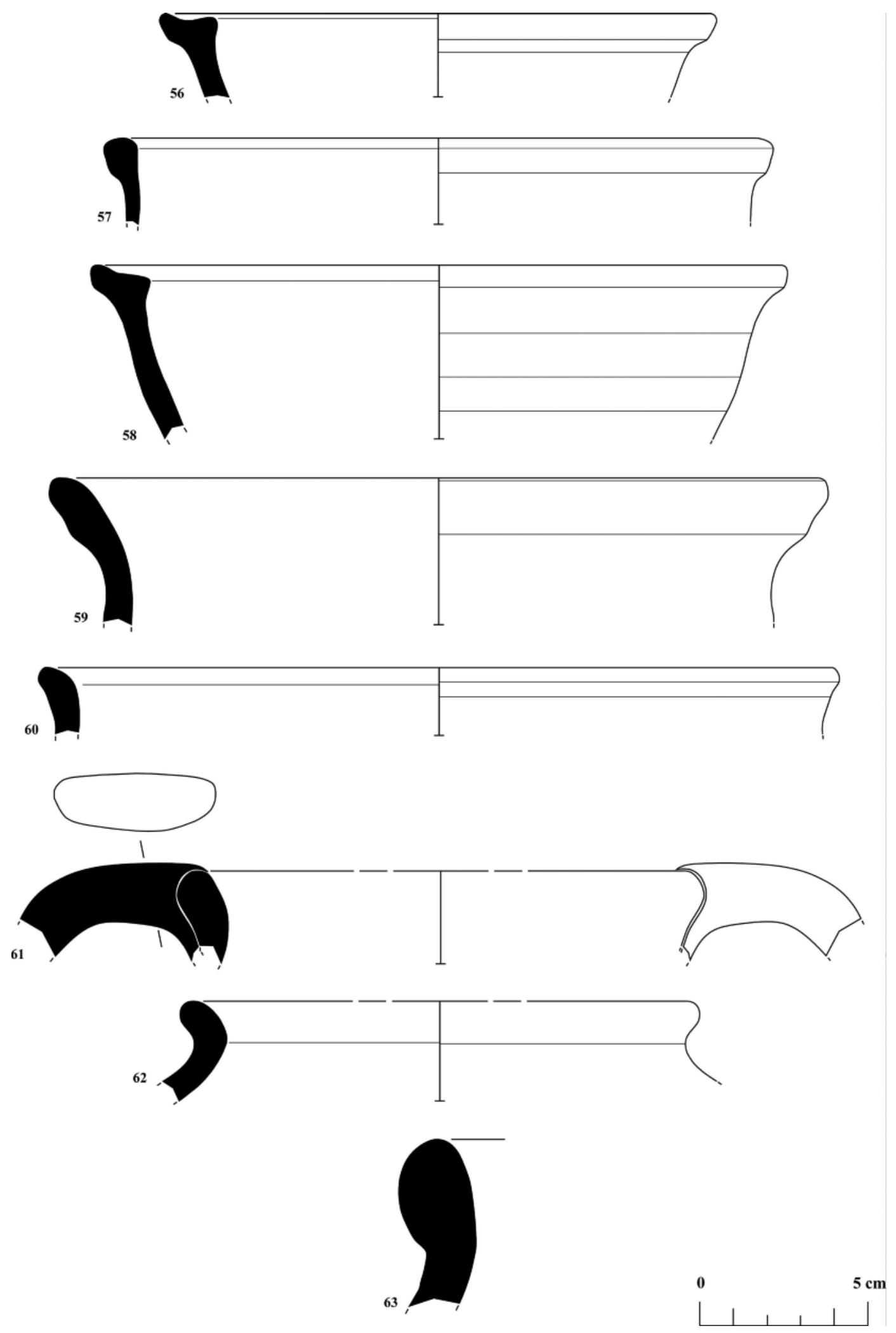

Pl. 5 : Nos $^{\text {56-63 }}$ : Kitchen ware; $n^{\text {os }}$ 56-62: Rim fragments of casseroles; and $n^{0}$ 63: A rim fragment of a basin/deep bowl. 
6/2) fabric with frequent tiny lime and small grit inclusions.

Late $8^{\text {th }}$-early $9^{\text {th }}$ century.

64- (No 986): Rim fragment; Kepez, found in 2005.

pl. 22/64.

Max. h $4.5 \mathrm{~cm}$., max. w $8.0 \mathrm{~cm}$., max. th $2.3 \mathrm{~cm}$.

Reddish yellow (5YR 6/6), unslipped surface both on exterior and interior. Soft paste; very sparsely porous, fine, yellowish red (5YR 5/6) fabric with some medium grit inclusions.

Late $10^{\text {th }}$-early $11^{\text {th }}$ cent. A.D.

65- (No 926): Rim fragment; Kimistene, Acropolis, found in 2005.

pl. $6 / 65$.

Max. h $4.8 \mathrm{~cm}$., d of rim $16.8 \mathrm{~cm}$., max. w $5.5 \mathrm{~cm}$., $\max$. th $1.2 \mathrm{~cm}$.

Brown (7.5YR 5/3) slip on exterior; light brown (7.5YR 6/3) slip on interior. Average hardness; nonporous, brown (7.5YR 5/4) very dark grey (2.5Y 4/1) mottled fabric with infrequent lime and some large grit inclusions.

$10^{\text {th }}$ cent. A.D.

66- (No 681): Rim fragment; Kimistene, cistern, eastern slope, found in 2005.

pl. 6/66.

Max. h $4.9 \mathrm{~cm}$., d of rim $20.6 \mathrm{~cm}$., max. w $5.7 \mathrm{~cm}$., max. th $1.4 \mathrm{~cm}$.

Brown (10YR 5/3), unslipped surface on exterior; brown (7.5YR 5/4), unslipped surface in interior. Soft paste; non-porous, yellowish red (5YR 5/6) fabric with some sand and lime inclusions.

$9^{\text {th }}$ cent. A.D.

67- (No 1074): Rim fragment; Kepez, found in 2005. pl. 6/67.

Max. h $5.2 \mathrm{~cm}$., d of rim $23.6 \mathrm{~cm}$., max. w $5.1 \mathrm{~cm}$., $\max$. th $1.2 \mathrm{~cm}$.

Exterior is burnished. Perhaps a large pottery stand, because of its very plain rim.

Greyish brown (10YR 5/2) slip on exterior; grey (10YR 5/1), unslipped surface in interior. Average hardness; sparsely porous, fine, grey (10YR 5/1) fabric with frequent tiny lime inclusions.

$9^{\text {th }}$ cent. A.D.

68- ( $\mathrm{N}^{\circ}$ 1288): Rim fragment; Kimistene, Acropolis, temple's terrace, found in 2005.

pl. 6/68.

Max. h $6.1 \mathrm{~cm}$. , d of rim $25.6 \mathrm{~cm}$., max. w $10.3 \mathrm{~cm}$., $\max$. th $1.5 \mathrm{~cm}$.

Light brownish grey (10YR 6/2) slip both on exterior and interior rim. Hard paste; non-porous, fine, greyish brown $(2.5 \mathrm{Y} 5 / 2)$ fabric with frequent lime and sand inclusions.

$10^{\text {th }}$ cent. A.D.

69- (No 638): Rim fragment; Kimistene, Acropolis, western slope, found in 2005.

pl. 6/69.

Max. h $3.7 \mathrm{~cm}$., d of rim $33.6 \mathrm{~cm}$., max. w $9.7 \mathrm{~cm}$., $\max$. th $1.4 \mathrm{~cm}$.

Pale brown (10YR 6/3) slip both on exterior and interior rim. Hard paste; non-porous, brown (7.5YR 5/3) and dark grey (10YR 4/1) mottled fabric with frequent lime and medium grit inclusions.

$10^{\text {th }}$ cent. A.D.

70- ( ${ }^{\circ}$ 102): Rim fragment; Kimistene, Acropolis, southern slope, just below of the summit of Deresemail creek, found in 2005.

pl. $6 / 70$.

Max. h $5.4 \mathrm{~cm}$., d of rim $36.0 \mathrm{~cm}$., max. w $5.6 \mathrm{~cm}$., $\max$. th $1.1 \mathrm{~cm}$.

Light red (2.5YR 6/6) slip on exterior; reddish yellow (5YR 6/6), unslipped surface in interior. Hard paste; nonporous, fine, reddish yellow (5YR 6/6) fabric with some sand and tiny lime inclusions.

$9^{\text {th }}$ cent. A.D.

71- ( $\mathrm{N}^{\circ}$ 925): Rim fragment; Kimistene, Acropolis, found in 2005 .

pl. $7 / 71$.

Max. h $4.4 \mathrm{~cm}$., d of rim $41.0 \mathrm{~cm}$., $\max$. w $7.9 \mathrm{~cm}$., $\max$. th $1.2 \mathrm{~cm}$

All of the surface is burnished.

Dark grey (10YR 4/1) slip both on exterior and interior rim. Hard paste; non-porous, fine, pale brown (10YR 6/3) fabric with some lime as well as sand and grog inclusions.

$10^{\text {th }}$ cent. A.D.

\section{Rim Fragments of the Closed Forms \\ (pls. 7-8, ${ }^{\text {os }} 76-90 ;$ pl. 22, $\mathrm{n}^{\text {os }} 72-75$ )}

Generally this group is consisting of medium sized pots, and there is no standardisation of rim size or shapes. Rim diameters are in a range of 6.6 and $18.6 \mathrm{~cm}$. They have either a short neck or are neckless. Some of them have a concave shoulder, recessed from the body which narrows from this point down. On $n^{\text {os }} 78,81-82,84-85$ and $87-88$ on pls. $7-8$ the shoulder is sloping up to a flaring rim with a rounded and short lip. In Tium similar unglazed wares with characteristic rim shapes were found ${ }^{70}$. Furthermore similar rim shapes are known from Saraçhane $^{71}$, in the Aegean ${ }^{72}$ and elsewhere in Asia Minor $^{73}$. Southwestern Paphlagonian fabrics and shapes have much similarity also with unglazed domestic wares

70) Toydemir Sabuncu $2011: 7$, fig. $4, n^{\circ} 3(271)\left(6^{\text {th }} / 7^{\text {th }}-13^{\text {th }}\right.$ or early $14^{\text {th }}$ cent. A.D. $)$.

71) Hayes 1992: 57-58, fig. 20.

72) Vionis et al. 2010: 458.

73) Böhlendorf-Arslan 2012: 162; and Cottica 2007: 260-266 (11 ${ }^{\text {th }}-13^{\text {th }}$ cent. A.D.) 

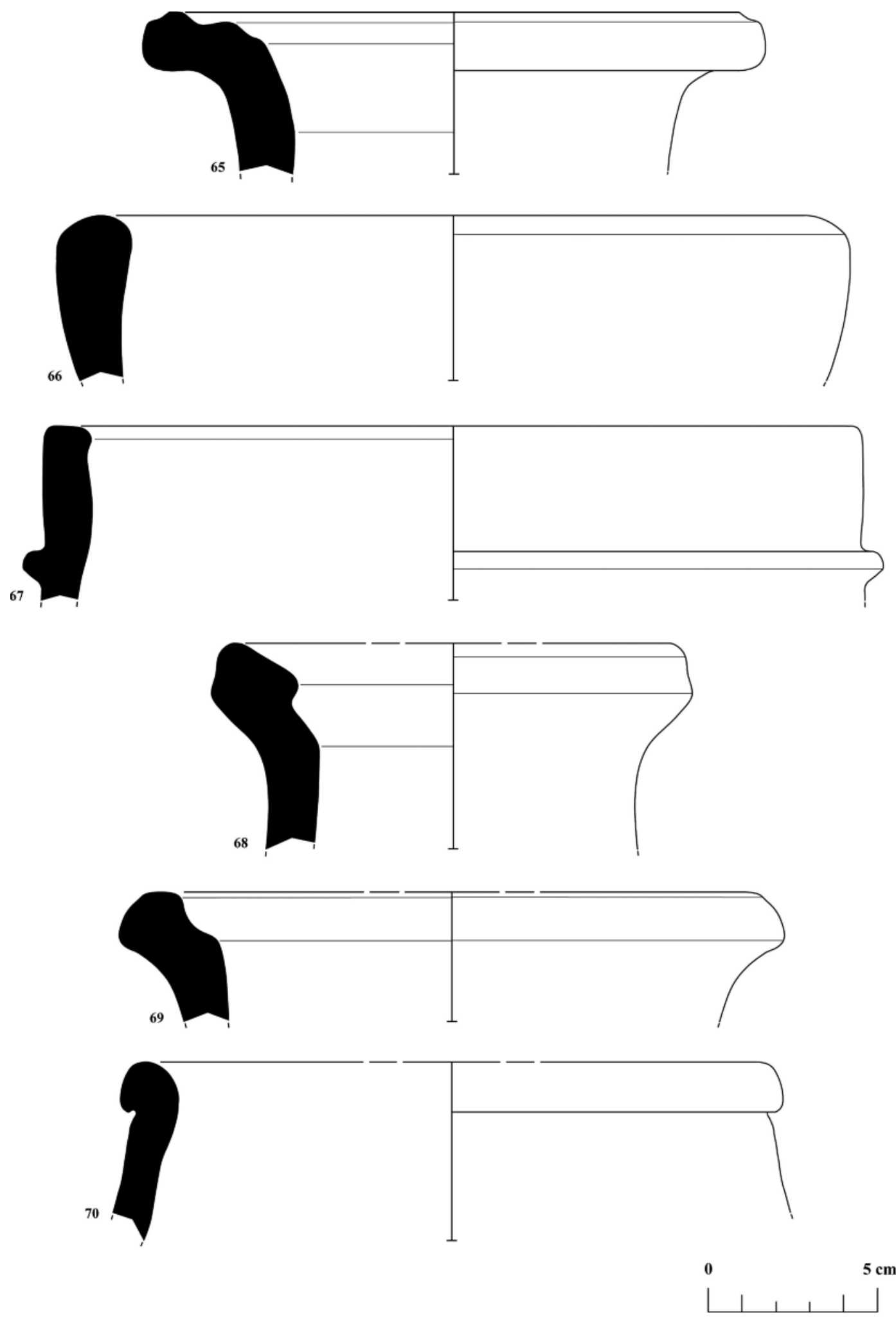

Pl. 6 : $\mathrm{N}^{\text {os }}$ 65-70 : Kitchen ware, rim fragments of basin/deep bowls. 
from the Medieval sites in western Anatolia, especially with Ephesus during the $13^{\text {th }}-14^{\text {th }}$ cent. A.D. ${ }^{74}$.

72- ( $\mathrm{N}^{0}$ 1051): Rim fragment; Kepez, found in 2005. pl. 22/72.

Max. h $1.5 \mathrm{~cm}$., max. w $2.1 \mathrm{~cm}$., max. th $0.7 \mathrm{~cm}$.

Light reddish brown (5YR 6/4), unslipped surface on exterior; reddish brown (5YR 6/6), unslipped surface in interior; reddish yellow (5YR 6/6) slip on interior rim which is also burnished. Average hardness; non-porous, fine, yellowish red (5YR 5/6) fabric with frequent tiny lime as well as sand and occasional mica inclusions.

Late $10^{\text {th }}$-early $11^{\text {th }}$ cent. A.D.

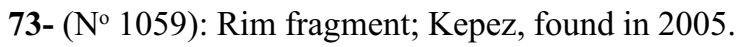
pl. 22/73.

Max. h $1.8 \mathrm{~cm}$., max. w $1.7 \mathrm{~cm}$., $\max$. th $0.5 \mathrm{~cm}$.

Light brownish grey (10YR 6/2), unslipped surface on exterior; light brown (7.5YR 6/4), unslipped surface in interior. Soft paste; sparsely porous, black (10YR 2/1) fabric with some lime inclusions.

Late $10^{\text {th }}$-early $11^{\text {th }}$ cent. A.D.

74- (№ 1311): Rim fragment; Kimistene, Acropolis, southern slope, found in 2005.

pl. 22/74.

Max. h $2.2 \mathrm{~cm}$., max. w $1.6 \mathrm{~cm}$., max. th $0.6 \mathrm{~cm}$.

Light brown (7.5YR 6/4), unslipped surface both on exterior and interior. Soft paste; sparsely porous, fine, light brown (7.5YR 6/4) fabric with some sand inclusions. $9^{\text {th }}$ cent. A.D.

75- ( $\mathrm{N}^{\circ}$ 1249): Rim fragment; Kimistene, western slope of the temenos, found in 2005.

pl. 22/75.

Max. h $2.5 \mathrm{~cm}$., max. w $3.9 \mathrm{~cm}$., max. th $0.6 \mathrm{~cm}$.

Reddish brown (5YR 5/4), unslipped surface both on exterior and interior. Soft paste; very sparsely porous, fine, reddish brown (5YR 5/4) fabric with some sand and tiny lime inclusions.

Late $10^{\text {th }}$-early $11^{\text {th }}$ cent. A.D.

76- ( $\mathrm{N}^{\mathrm{o}}$ 1046): Rim fragment; Kepez, found in 2005. pl. $7 / 76$.

Max. h $2.8 \mathrm{~cm}$., max. w $2.4 \mathrm{~cm}$., max. th $0.6 \mathrm{~cm}$.

Reddish yellow (5YR 6/6) slip both on exterior and interior rim; reddish yellow (5YR 6/6), unslipped surface on lower interior. Soft paste; sparsely porous, fine, yellowish red (5YR 5/6) fabric with frequent tiny lime inclusions.

Late $8^{\text {th }}$-early $9^{\text {th }}$ cent. A.D.

77- (No 1004): Rim fragment ${ }^{75}$; Kepez, found in 2005. pl. $7 / 77$.

Max. h $2.9 \mathrm{~cm}$., d of rim $6.6 \mathrm{~cm}$., max. w $4.1 \mathrm{~cm}$., $\max$. th $0.6 \mathrm{~cm}$.
Light brown (7.5YR 6/3), unslipped surfaceboth on exterior and interior. Average hardness; very sparsely porous, fine, reddish brown (5YR 5/4) fabric with frequent tiny lime inclusions.

Late $10^{\text {th }}$-early $11^{\text {th }}$ cent. A.D.

78- ( $\mathrm{N}^{\circ}$ 1211): Rim fragment; Kimistene, summit of the Acropolis, southern slope, found in 2005.

pl. $7 / 78$.

Max. h $5.0 \mathrm{~cm}$., d of rim $12.0 \mathrm{~cm}$., max. w $6.1 \mathrm{~cm}$., $\max$. th $0.9 \mathrm{~cm}$

Rim and shoulder of a pot or jar. Exterior and interior rim is burnished as well as blackened.

Greyish brown (10YR 5/2) abraded slip both on exterior and interior rim; light brownish grey (10YR 6/2), unslipped surface on lower interior. Average hardness; non-porous, fine, dark greyish brown (10YR 4/2) fabric with occasional tiny lime and mica inclusions.

Late $9^{\text {th }}$-early $10^{\text {th }}$ century.

79- ( $\mathrm{N}^{\mathrm{o}}$ 1076): Rim fragment; Kepez, found in 2005. pl. 7/79.

Max. h $2.6 \mathrm{~cm}$., d of rim $12.2 \mathrm{~cm}$., max. w $5.1 \mathrm{~cm}$., $\max$ th $1.0 \mathrm{~cm}$.

Light brown (7.5YR 6/4) slip both on exterior and interior. Average hardness; non-porous, fine, reddish yellow (5YR 6/6) fabric with frequent lime and small grit inclusions.

Late $8^{\text {th }}$-early $9^{\text {th }}$ century.

80- ( No 1459): Rim fragment; Kimistene, Acropolis, found in 2005 .

pl. $7 / 80$.

Max. h $2.2 \mathrm{~cm}$., d of rim $12.4 \mathrm{~cm}$., max. w $5.7 \mathrm{~cm}$., $\max$. th $1.3 \mathrm{~cm}$.

Two shallow grooves below the rim on the exterior. Light reddish brown (5YR 6/4), unslipped surface both on exterior and interior. Soft paste; non-porous, fine, brown (7.5YR 5/4) fabric with some sand inclusions.

Late $10^{\text {th }}$-early $11^{\text {th }}$ cent. A.D.

81- (No 447): Rim fragment; Kimistene, Acropolis, southern slope, just below the summit, towards Deresemail creek, found in 2005.

pl. $7 / 81$.

Max. h $4.1 \mathrm{~cm}$. , d of rim $12.6 \mathrm{~cm}$., max. w $7.2 \mathrm{~cm}$., max. th $0.7 \mathrm{~cm}$.

Pink (7.5YR 7/4), unslipped surface both on exterior and interior. Hard paste; non-porous, light brown and (7.5YR 6/4) and light red (2.5YR 6/6) mottled fabric with frequent tiny lime and some sand inclusions.

$9^{\text {th }}$ cent. A.D.

82- ( $\left.\mathrm{N}^{\circ} 1399\right)$ : Rim fragment; Kimistene, summit of the Acropolis, surface find, found in 2005.

74) Vroom 2008: 22; and 2005: 35-36.

75) Similar rim profiles: Böhlendorf-Arslan 2012: 154, fig. 2.1; Bakirtzis 1989: 36, fig. 1.1 (10 ${ }^{\text {th }}$ cent. A.D.); and Hayes 1992: 56, fig. $20, \mathrm{n}^{\circ} 2$. 

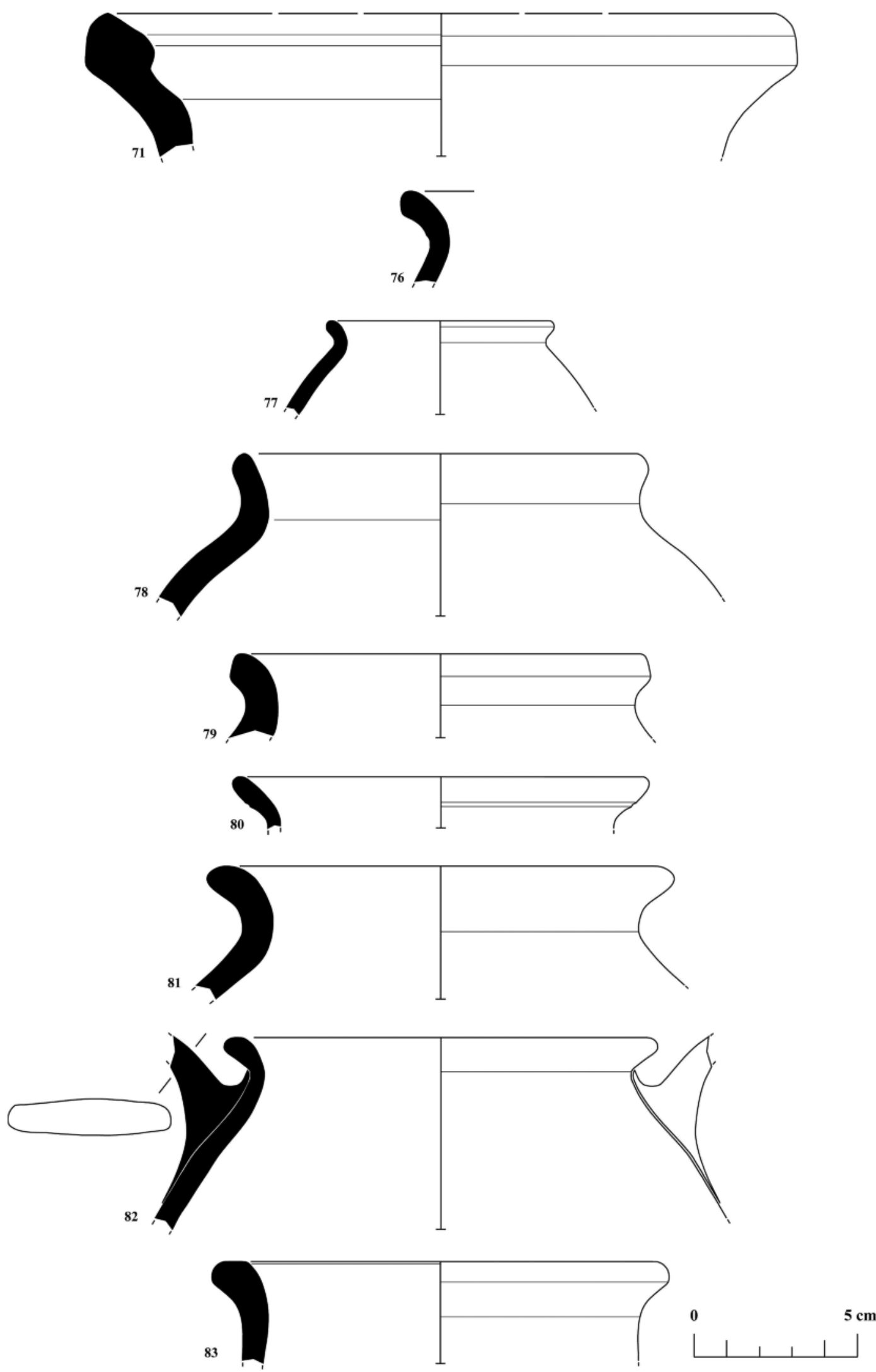

Pl. 7 : $\mathbf{N}^{\text {os }}$ 71-83 : Kitchen ware; $\mathrm{n}^{0} 71$ : A rim fragment of a basin/deep bowl; and $n^{\text {os }}$ 76-83: Rim fragments of the closed forms. 
pl. $7 / 82$.

Handle and rim of a small pot/jug?

Max. h $5.9 \mathrm{~cm}$., d of rim $12.6 \mathrm{~cm}$., max. w $7.1 \mathrm{~cm}$., max. th $0.6 \mathrm{~cm}$.

Light brownish grey (10YR 6/2) slip on exterior; reddish brown (5YR 5/3) slip on interior. Soft paste; nonporous, fine, red $(2.5 \mathrm{YR} 5 / 6)$ fabric with frequent tiny lime and sand inclusions.

$9^{\text {th }}$ cent. A.D.

83- ( $\mathrm{N}^{\circ}$ 94): Rim fragment; Bath $\mathrm{B}$, room 5 , found in 2007.

pl. 7/83.

Max. h $3.2 \mathrm{~cm}$., d of rim $13.2 \mathrm{~cm}$., max. w $6.1 \mathrm{~cm}$., $\max$. th $0.8 \mathrm{~cm}$.

Pot/table amphora? Exterior is burnished.

Grey (10YR 5/1), unslipped surface both on exterior and interior. Average hardness; very sparsely porous, fine, very dark grey (2.5Y 3/1) fabric with some sand and lime inclusions.

$10^{\text {th }}$ cent. A.D.

84- ( $\left.\mathrm{N}^{\circ} 1215\right)$ : Rim fragment; Kimistene, summit of the Acropolis, southern slope, found in 2005.

pl. 8/84.

Max. h $3.4 \mathrm{~cm}$., d of rim $13.4 \mathrm{~cm}$., max. w $4.2 \mathrm{~cm}$., max. th $0.6 \mathrm{~cm}$.

Both exterior and interior rim are burnished. Dark brown (7.5YR 4/1) slip both on exterior and interior rim. Average hardness; non-porous, fine, very dark greyish brown (10YR 4/2) fabric with frequent tiny lime and sand inclusions.

$9^{\text {th }}$ cent. A.D.

85- ( No $^{0}$ 1225): Rim fragment; Kimistene, summit of the Acropolis, southern slope, found in 2005.

pl. 8/85.

Max. h $5.3 \mathrm{~cm}$., d of rim $14.1 \mathrm{~cm}$., max. w $6.7 \mathrm{~cm}$., $\max$. th $0.8 \mathrm{~cm}$.

Rim and shoulder of a pot or jar. Exterior surface and interior rim are burnished. Interior surface is blackened.

Brown (7.5YR 4/2) slip both on exterior and interior rim. Average hardness; very sparsely porous, fine, brown (7.5YR 4/4) fabric with frequent lime and medium grit inclusions.

$9^{\text {th }}$ cent. A.D.

86- $\left(\mathrm{N}^{0}\right.$ 1339): Rim fragment ${ }^{76}$; Kimistene, cistern, eastern slope, surface find, found in 2005.

pl. 8/86.

Max. h $2.4 \mathrm{~cm}$., d of rim $14.4 \mathrm{~cm} \max$. w $4.5 \mathrm{~cm}$., $\max$. th $0.5 \mathrm{~cm}$.

Interior surface is blackened.
Light brownish grey (10YR 6/2), unslipped surface on exterior; very dark grey (10YR 3/1), unslipped surface in interior. Average hardness; very sparsely porous, fine, greyish brown (10YR 5/2) fabric with frequent tiny lime and some medium grit inclusions.

Late $8^{\text {th }}$-early $9^{\text {th }}$ cent. A.D.

87- ( $\left.\mathrm{N}^{\circ} 375\right)$ : Rim fragment; Kimistene, Acropolis, southern slope, just below the summit, towards Deresemail creek, found in 2005.

pl. 8/87.

Max. h $3.8 \mathrm{~cm}$., d of rim $15.0 \mathrm{~cm}$., max. w $6.2 \mathrm{~cm}$., $\max$. th $1.0 \mathrm{~cm}$.

Light brownish grey (2.5Y 6/2) slip on exterior; light brownish grey $(2.5 \mathrm{Y} 6 / 2)$, unslipped surface in interior. Hard paste; sparsely porous, greyish brown (2.5Y 5/2) and very dark grey (Gley $13 / \mathrm{N}$ ) mottled fabric with frequent tiny lime as well as rare mica and some medium grit inclusions.

Late $8^{\text {th }}$-early $9^{\text {th }}$ cent. A.D.

88- (No 651): Rim fragment; Kepez, found in 2005. pl. 8/88.

Max. h $3.9 \mathrm{~cm}$., d of rim $17.0 \mathrm{~cm}$., max. w $7.2 \mathrm{~cm}$., $\max$. th $0.5 \mathrm{~cm}$.

Dark grey (10YR 4/1), unslipped surface both on exterior and interior. Hard paste; very sparsely porous, dark greyish brown (10YR 4/2) fabric with some sand and lime inclusions

Late $10^{\text {th }}$-early $11^{\text {th }}$ cent. A.D.

89- ( $\mathrm{N}^{\circ}$ 1216): Rim fragment; Kimistene, summit of the Acropolis, southern slope, found in 2005.

pl. 8/89.

Max. h $3.8 \mathrm{~cm}$., d of rim $17.6 \mathrm{~cm}$., max. w $7.2 \mathrm{~cm}$., max. th $0.8 \mathrm{~cm}$.

Light brown (7.5YR 6/4) slip on exterior; grey (7.5YR $6 / 1$ ), unslipped surface in interior. Hard paste; non-porous, dark grey (10YR 4/1) fabric with frequent tiny lime inclusions.

Late $9^{\text {th }}$-early $10^{\text {th }}$ cent. A.D.

90- ( $\mathrm{N}^{\circ}$ 1308): Rim fragment; Kimistene, Acropolis, northeastern slope of the temple, found in 2005.

pl. 8/90.

Max. h $2.3 \mathrm{~cm}$., d of rim $18.6 \mathrm{~cm}$., max. w $3.0 \mathrm{~cm}$., $\max$. th $0.9 \mathrm{~cm}$.

Greyish brown (10YR 5/2), unslipped surface on exterior; dark grey (10YR 4/1), unslipped surface in interior. Soft paste; very sparsely porous, brown (7.5YR 4/3) fabric with frequent tiny lime and sand inclusions.

Late $10^{\text {th }}$-early $11^{\text {th }}$ cent. A.D. 


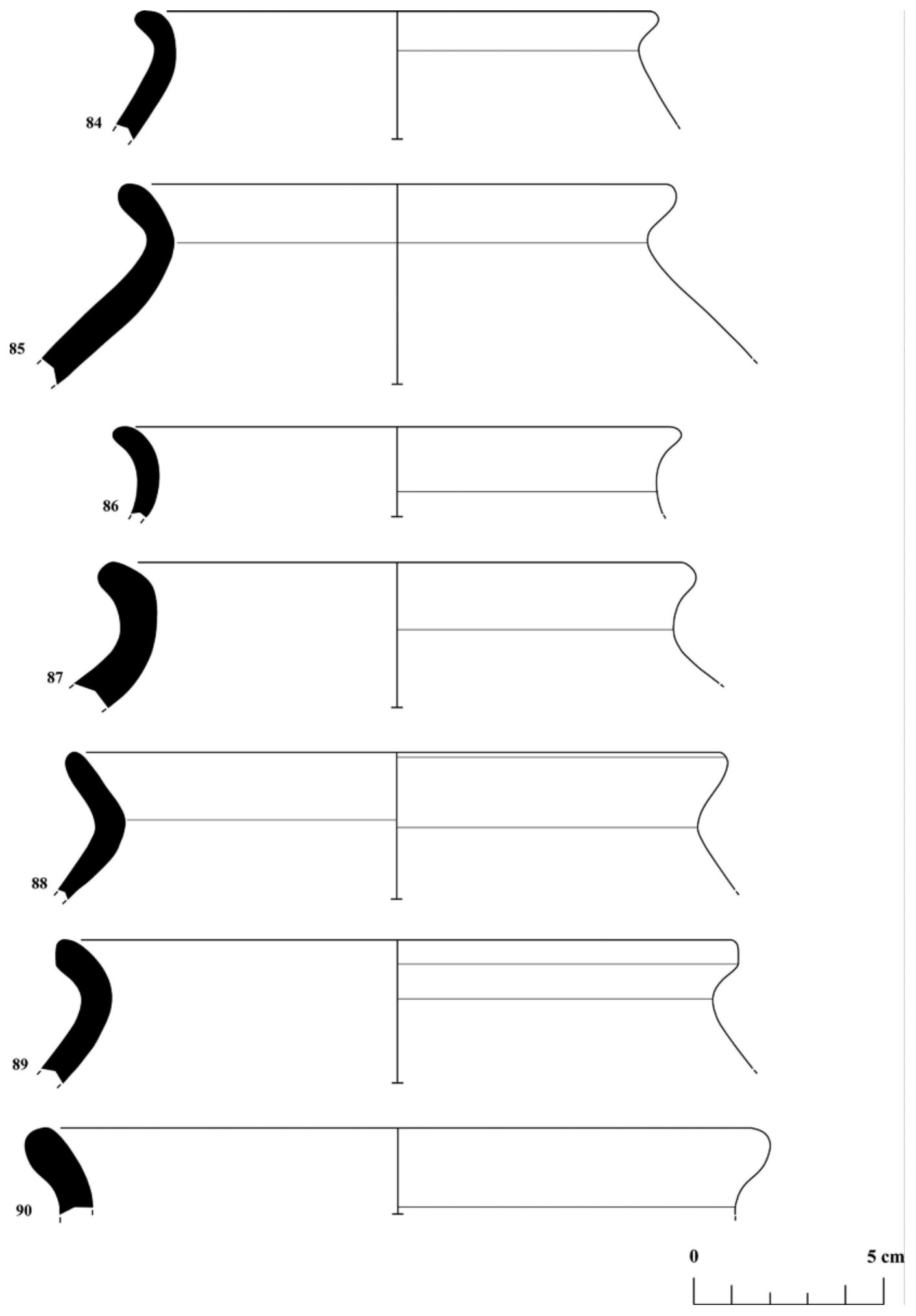

PI. 8 : Nos 84-90 : Kitchen ware, rim fragments of the closed forms. 


\author{
3. Storage Ware \\ (pls. 9-14, nos 91-121; pl. 22, no 111) \\ Pithoid Vessels and Pithoi \\ (pls. 9-14, $\mathrm{n}^{\text {os }}$ 91-121; pl. 22, $\mathrm{n}^{\mathrm{o}} 111$ )
}

In the summit of the Acropolis of Kimistene there was definitely a storage area; most of the stored agricultural products should be grain. Middle Byzantine storage ware in southwestern Paphlagonia consists of common vessel forms for dried foodstuffs and liquids, such as water, oil, wine, vinegar and milk. Pithoi, i.e. large jars used for storage purposes, are very common in Middle Byzantine contexts in Asia Minor ${ }^{77}$. Fragments of pithoi are mostly thick-walled shapes with a flat base. The most common feature for all types of these vessels in southwestern Paphlagonia is an everted, outturned or thickened rim. Some examples have a hatched rim profile, as $\mathrm{n}^{\text {os }} 99$ and 105 on pls. 10-11. They have sometimes a decoration of applied rope bands ${ }^{78}$. Rim diameters of these vessels change from 11.8 to $57.0 \mathrm{~cm}^{79}$. Similar forms (pls. 9-10, $\mathrm{n}^{\text {os }} 93$ and 98-99) in smaller versions are also quite popular in Hierapolis $^{80}$. Most of storage jars/pithoi were made of red, yellow or brown fabric. Inclusions at the Middle Byzantine pithoid vessels and pithoi from southwestern Paphlagonia consist of grit (elongated, but with rounded corners), lime and pores, and they are of medium quantity and sorting. They are generally smaller than $1.5 \mathrm{~mm}$. Their fabric is rather soft ( 3.5 on the Mohs scale) and breaks are rough. Their sherds have an even surface feel and clay is fine as well as homogeneous.

Artefactual evidence retrieved from the surveys and excavations in southwestern Paphlagonia provides a broad-ranging insight on pithoi, such as their usage for grain, viticultural production as well as storage in Kimistene (Fig. 14) and for manufacturing activities at storage rooms in Hadrianoupolis ${ }^{81}$. Although the typological development of large storage vessels has not been studied in depth and there is not much published information about the pithoi in Middle Byzantine Asia Minor, they tend to remain unchanged for long periods of time ${ }^{82}$. The life duration of pithoi were even prolonged through their restoration ${ }^{83}$.
Around 500 unglazed coarse ware sherds of storage and transport ware were collected at the citadel of Tium and among the unglazed wares seven fabric genres were identified ${ }^{84}$. Due to their poor conditions these sherds are hard to ascribe to any known classes; however, because of their globular shapes, amphorae and storage vessels resemble Middle and Late Byzantine forms, well known from other parts of the Black Sea ${ }^{85}$. Similar rim fragments to the storage vessels from southwestern Paphlagonia were found at elsewhere in Middle Byzantine Asia Minor and Greece ${ }^{86}$.

91- (No 913): Rim fragment; Kimistene, Acropolis, southeastern slope, on the way to the cistern, on a rocky slope, surface find, found in 2005.

pl. 9/91.

Overhanging, thickened and triangular sectioned rim with a flat top.

Max. h $2.4 \mathrm{~cm}$., d of rim $11.8 \mathrm{~cm}$., max. w $8.5 \mathrm{~cm}$., max. th $1.2 \mathrm{~cm}$.

Reddish yellow (5YR 6/6), unslipped surface both on exterior and interior. Hard paste; non-porous, fine, light red (2.5YR 6/8) fabric with some tiny lime inclusions.

Early $10^{\text {th }}$ cent. A.D.

92- ( $\mathrm{N}^{\circ}$ 456): Rim fragment; Kimistene, Acropolis, southern slope, just below the summit, towards Deresemail creek, found in 2005 .

pl. 9/92.

Max. h $5.4 \mathrm{~cm}$., d of rim $15.1 \mathrm{~cm}$., max. w $5.3 \mathrm{~cm}$., $\max$. th $0.7 \mathrm{~cm}$.

Light brown (7.5YR 6/4), unslipped surface on exterior; red (2.5YR 5/6), unslipped surface in interior. Hard paste; non-porous, fine, red (2.5YR 5/6) fabric with occasional tiny lime and mica inclusions.

Late $9^{\text {th }}$-early $10^{\text {th }}$ cent. A.D.

93- (No 978): Rim fragment; Hadrianoupolis, surface find, found in 2005 .

pl. 9/93.

Max. h $5.5 \mathrm{~cm}$., d of rim $16.0 \mathrm{~cm}$., max. w $7.9 \mathrm{~cm}$., $\max$. th $1.2 \mathrm{~cm}$.

77) For instance, pithoi from Tahir(ler) Project: accessed from $<$ http://digitalcollections.lib.washington.edu/cdm/singleitem/ collection/tahirler/id/605/rec/6> (20/09/2015); and Cottica 2007: 263, fig. 12, nos $1-6$.

78) Similar examples: Vroom 2008: 22.

79) Similarly to Cottica 2007: 263, fig. $11, \mathrm{n}^{\text {os }} 2-5$ and $7-8$.

80) Cottica 2007: 263, fig. 11, $\mathrm{n}^{\text {os }} 9-11$.

81) For the Roman and Early Byzantine viticulture of southwestern Paphlagonia $c f$ :: Lafl1 2012

82) Vionis et al. 2010: 443.

83) Peña 2007: 46-47. Although there is no direct evidence regarding the use-life of pithoi in absolute terms, it seems likely that a significant number of these containers remained in prime use for extremely long periods of time. Ethnographic research indicates that in some cases large storage vessels remain in use for several decades (Rice 1987: 297), and it thus seems plausible to suggest that pithoi regularly remained in prime use for up to 20-30 years, and perhaps even longer.

84) Anderson 2009: 270, appendix B.

85) Anderson 2009: 270; Günsenin 1989; Bakirtzis 1989; and Hayes 1992: 75-77.

86) For Greek examples in the Byzantine and Christian Museum in Thessaloniki, accessed from $<\mathrm{http}: / /$ www.byzantinemuseum.gr/en/collections/ceramics/> (20/09/2015). 

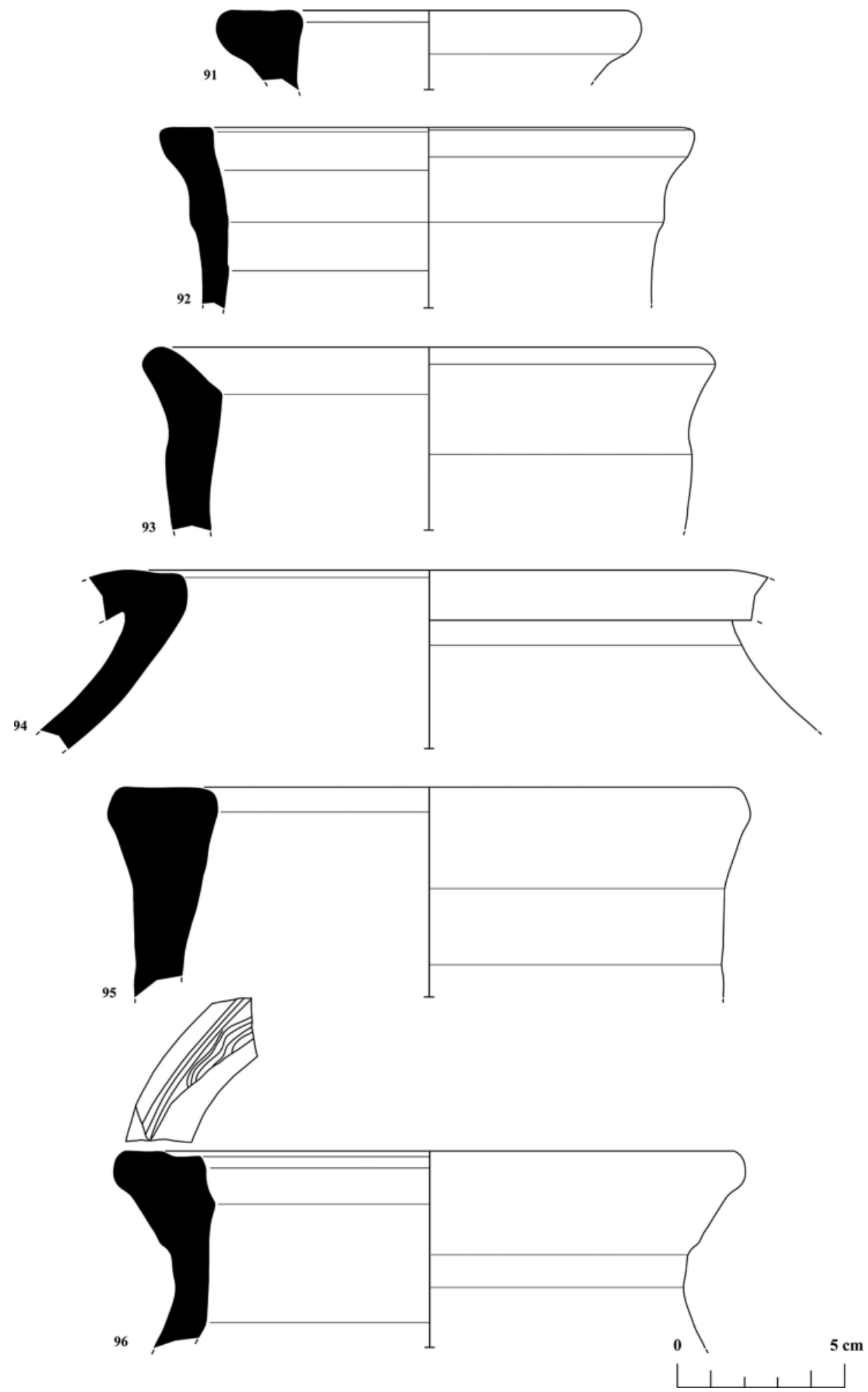

PI. 9 : Nos 91-96 : Storage ware, rim fragments of pithoid vessels and pithoi. 
Reddish yellow (5YR 6/6), unslipped surface both on exterior and interior. Hard paste; non-porous, fine, reddish yellow (5YR 6/6) fabric with some sand inclusions.

Late $9^{\text {th }}$-early $10^{\text {th }}$ cent. A.D.

94- ( $\mathrm{N}^{\circ}$ 629): Rim fragment; Kimistene, Acropolis, found in 2005.

pl. $9 / 94$.

Max. h $4.8 \mathrm{~cm}$., d of rim $18.0 \mathrm{~cm}$., max. w $6.9 \mathrm{~cm}$., $\max$. th $0.7 \mathrm{~cm}$.

Red (2.5YR 5/6), unslipped surface both on exterior and interior. Hard paste; non-porous, fine, red (2.5YR 5/6) fabric with some tiny lime inclusions.

$9^{\text {th }}$ cent. A.D.

95- ( $\mathrm{N}^{\circ}$ 867): Rim fragment; Kimistene, Acropolis, temple's terrace, in the illegal trench around the altar, found in 2005 .

pl. 9/95.

Max. h $6.3 \mathrm{~cm}$., d of rim $18.2 \mathrm{~cm}$., max. w $8.4 \mathrm{~cm}$., $\max$. th $1.5 \mathrm{~cm}$.

Light red (2.5YR 6/6) slip on exterior; light reddish brown (5YR 6/4), unslipped surface in interior. Hard paste; non-porous, yellowish red (5YR 5/6) fabric with some medium grit as well as lime and sand inclusions.

$9^{\text {th }}$ cent. A.D.

96- (No 910): Rim fragment; Kimistene, Acropolis, southeastern slope, on the way to the cistern, on a rocky slope, surface find, found in 2005.

pl. 9/96.

Max. h 5.9 cm., d of rim $18.2 \mathrm{~cm}$., max. w $10.9 \mathrm{~cm}$. Incised wavy lines decoration in a band on the lip.

Light red (2.5YR 6/8) slip both on exterior and interior. Hard paste; non-porous, fine, light red (2.5YR $6 / 8$ ) fabric with some sand as well as small grit and lime inclusions.

$9^{\text {th }}$ cent. A.D.

97- ( ${ }^{\circ}$ 640): Rim fragment; Kimistene, Acropolis, western slope, found in 2005.

pl. 10/97.

Max. h $5.1 \mathrm{~cm}$., d of rim $18.4 \mathrm{~cm}$., max. w $7.0 \mathrm{~cm}$., max. th $0.9 \mathrm{~cm}$.

Light red (2.5YR 6/8) slip on exterior; light reddish brown (2.5YR 6/4) slip on interior. Hard paste; sparsely porous, fine, light red (2.5YR 6/6) fabric with frequent tiny lime and small grit inclusions.

$9^{\text {th }}$ cent. A.D.

98- ( $\mathrm{N}^{\circ}$ 454): Rim fragment; Kimistene, Acropolis, southern slope, just below the summit, towards Deresemail creek, found in 2005 . pl. 10/98.

Max. h $3.1 \mathrm{~cm}$., d of rim $18.4 \mathrm{~cm}$., max. w $6.5 \mathrm{~cm}$., max. th $1.0 \mathrm{~cm}$.

Reddish yellow (7.5YR 5/6), unslipped surface both on exterior and interior. Hard paste; non-porous, reddish yellow (5YR 6/8) fabric with some sand inclusions.

Late $8^{\text {th }}$-early $9^{\text {th }}$ cent. A.D.

99- ( $\mathrm{N}^{\circ}$ 694): Rim fragment; Kimistene, cistern, eastern slope, found in 2005.

pl. 10/99.

Max. h $3.3 \mathrm{~cm}$., d of rim $18.6 \mathrm{~cm}$., max. w $7.0 \mathrm{~cm}$., max. th $0.7 \mathrm{~cm}$.

Red (2.5YR 5/6) slip on exterior; light red (2.5YR $6 / 8)$, unslipped surface in interior. Hard paste; non-porous, fine, red (2.5YR 5/8) fabric with frequent tiny lime and some sand inclusions.

$9^{\text {th }}$ cent. A.D.

100- (No 1114): Rim fragment; Kimistene, Acropolis, found in 2005 .

pl. $10 / 100$.

Max. h $7.1 \mathrm{~cm}$., d of rim $20.8 \mathrm{~cm}$., max. w $10.3 \mathrm{~cm}$., $\max$. th $1.4 \mathrm{~cm}$.

Everted and thickened rim.

Very pale brown (10YR 8/3) slip both on exterior and interior. Hard paste; non-porous, fine, very pale brown (10YR 7/4) fabric with some medium grit and rare mica inclusions.

Late $8^{\text {th }}$-early $9^{\text {th }}$ cent. A.D.

101- ( $\mathrm{N}^{\circ}$ 868): Rim fragment; Kimistene, Acropolis, southern slope, underground cave, surface find, found in 2005 .

pl. 10/101.

Max. h $5.1 \mathrm{~cm}$., d of rim $21.0 \mathrm{~cm}$., max. w $9.0 \mathrm{~cm}$. max. th $0.9 \mathrm{~cm}$.

Triangular sectioned rim with a flat top. Applied cordon with finger impressions (pinched decoration) below exterior rim ${ }^{87}$.

Reddish yellow (5YR 6/6) slip both on exterior and interior. Hard paste; non-porous, fine, reddish yellow (5YR 6/8) fabric with frequent lime inclusions.

$9^{\text {th }}$ cent. A.D.

102- ( $\mathrm{N}^{\circ}$ 831): Rim fragment; Kimistene, cistern, eastern slope, found in 2005.

pl. 10/102.

Max. h $5.8 \mathrm{~cm}$., d of rim $21.2 \mathrm{~cm}$., max. w $12.3 \mathrm{~cm}$., $\max$. th $1.0 \mathrm{~cm}$.

Triangular sectioned rim with a flat top ${ }^{88}$

Reddish yellow (5YR 6/6), unslipped surface both on exterior and interior. Hard paste; non-porous, fine,

87) A similar decoration on a deep basin: Intagliata 2014: 651, fig. 9. This sherd presents a thick rim with an oval section and a flange beneath it, decorated with finger-impressed scallops. It should be dated to $6^{\text {th }}-8^{\text {th }}$ cent. A.D. Another similar one: Devos 2003 : 371-372, figs. 235 and 237.

88) A similar rim profile: Kaptijn et al. 2013: 85-86, fig. 10.2. 

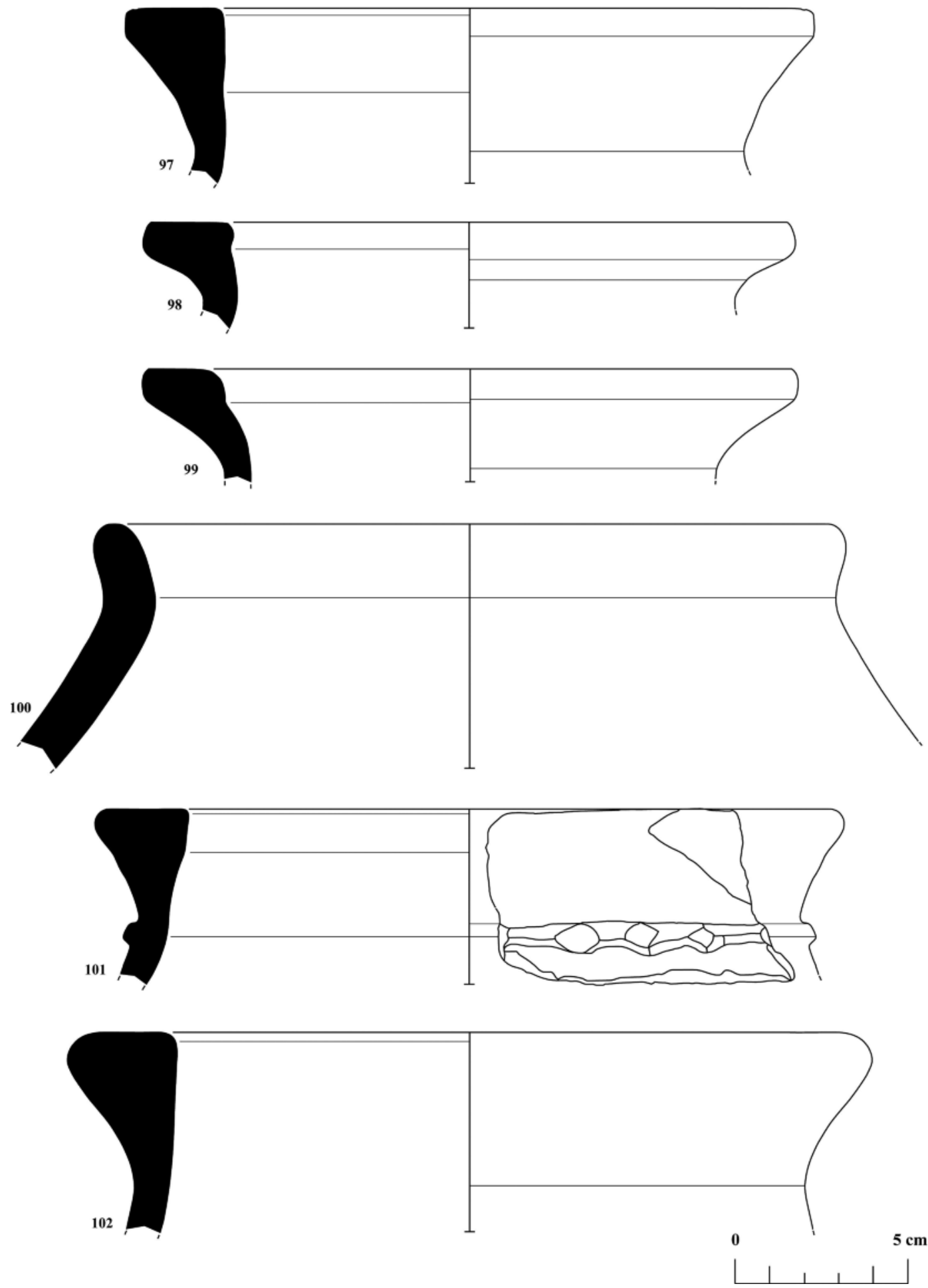

Pl. 10 : Nos 97-102 : Storage ware, rim fragments of pithoid vessels and pithoi. 
reddish yellow (5YR 6/6) fabric with some tiny lime inclusions.

$$
\text { Late } 8^{\text {th }} \text {-early } 9^{\text {th }} \text { cent. A.D. }
$$

103- ( $\mathrm{N}^{\circ}$ 1402): Rim fragment; Kimistene, Acropolis, temple's terrace, surface find, found in 2005.

pl. 11/103.

Max. h $6.2 \mathrm{~cm}$. , d of rim $21.2 \mathrm{~cm}$., max. w $11.1 \mathrm{~cm}$., max. th $1.6 \mathrm{~cm}$.

Flat rim and thin wall ${ }^{89}$

Yellowish red (5YR 5/6), unslipped surface both on exterior and interior. Hard paste; non-porous, fine, reddish yellow (5YR 6/6) fabric with rare sand inclusions.

$9^{\text {th }}$ cent. A.D.

104- ( $\mathrm{N}^{\circ}$ 637): Rim fragment; Kimistene, Acropolis, western slope, found in 2005.

pl. 11/104.

Max. h 4.9 cm., d of rim $23.2 \mathrm{~cm}$., max. w $13.9 \mathrm{~cm}$., $\max$. th $0.9 \mathrm{~cm}$.

Red (2.5YR 5/6) slip on exterior; red (2.5YR 5/6), unslipped surface in interior. Hard paste; very sparsely porous, yellowish red (5YR 5/6) fabric with infrequent lime and some sand inclusions.

Early $10^{\text {th }}$ cent. A.D.

105- ( $\mathrm{N}^{\circ}$ 704): Rim fragment; Kimistene, Acropolis, temple's eastern slope, surface find, found in 2005.

pl. 11/105.

Max. h $8.2 \mathrm{~cm}$., d of rim $27.4 \mathrm{~cm}$., max.w $3.8 \mathrm{~cm}$, $\max$. th $1.1 \mathrm{~cm}$.

Pale brown (10YR 6/3), unslipped surface on exterior; light brownish grey (10YR 6/2), unslipped surface in interior. Hard paste; non-porous, brown (7.5YR 4/3) fabric with rare mica and grit inclusions.

$10^{\text {th }}$ cent. A.D.

106- (No 1441): Rim fragment; Kimistene, Acropolis, temple's terrace, found in 2005.

pl. 11/106.

Max. h $6.4 \mathrm{~cm}$., d of rim $30.0 \mathrm{~cm}$., max. w $14.5 \mathrm{~cm}$., $\max$. th $2.0 \mathrm{~cm}$.

Reddish yellow (5YR 6/6), unslipped surface both on exterior and interior. Average hardness; sparsely porous, fine, reddish yellow (5YR 6/6) fabric with frequent lime and some medium grit inclusions.

$10^{\text {th }}$ cent. A.D.

107- ( $\mathrm{N}^{\mathrm{0}}$ 1473): Rim fragment; surface find from the village Boncuklar, found in 2005.

pl. 11/107.

Max. h $4.4 \mathrm{~cm}$., d of rim $31.8 \mathrm{~cm}$., max. w $9.6 \mathrm{~cm}$., $\max$ th $0.8 \mathrm{~cm}$.
Red (2.5YR 5/6), unslipped surface on exterior; red (2.5YR 5/6), unslipped surface in interior. Hard paste; non-porous, reddish brown $(2.5 \mathrm{YR} 4 / 4)$ fabric with some lime and medium grit as well as rare mica inclusions.

$9^{\text {th }}$ cent. A.D.

108- ( ${ }^{\circ}$ 1318): Rim fragment; Kimistene, summit of the Acropolis, southern slope, found in 2005.

pl. $12 / 108$.

Max. h $5.4 \mathrm{~cm}$., d of rim $31.8 \mathrm{~cm}$., max. w $12.7 \mathrm{~cm}$., max. th $1.4 \mathrm{~cm}$.

Very pale brown (10YR 7/3) slip both on exterior and interior. Hard paste; very sparsely porous, fine, brown (7.5YR 5/4) fabric with frequent lime and small grit as well as rare mica inclusions.

Late $9^{\text {th }}$-early $10^{\text {th }}$ cent. A.D.

109- ( $\mathrm{N}^{\circ}$ 632): Rim fragment; Kimistene, Acropolis, found in 2005 .

pl. $12 / 109$.

Max. h $7.6 \mathrm{~cm}$., d of rim $33.0 \mathrm{~cm}$., max. w $10.9 \mathrm{~cm}$., $\max$. th $1.8 \mathrm{~cm}$.

Very pale brown (10YR 7/3), unslipped surface both on exterior and interior. Average hardness; very sparsely porous, fine, very pale brown (10YR 7/4) fabric with some medium grit inclusions.

Late $9^{\text {th }}$-early $10^{\text {th }}$ cent. A.D.

110- ( $\mathrm{N}^{\circ}$ 636): Rim fragment; Kimistene, Acropolis, found in 2005 .

pl. 12/110.

Max. h 7.8 cm., d of rim $33.0 \mathrm{~cm} ., 16$ max. w 12.8 cm., max. th $1.2 \mathrm{~cm}$.

Light red (2.5YR 6/8) slip on exterior; light red (2.5YR 6/8), unslipped surface in interior. Hard paste; non-porous, red (2.5YR 5/8) fabric with some tiny lime as well as medium grit and sand inclusions.

$9^{\text {th }}$ cent. A.D.

111- ( $\left.\mathrm{N}^{\mathrm{o}} 1255\right)$ : Rim fragment; Kimistene, Necropolis I, surface find, found in 2005 .

pl. 22/111.

Max. h $8.0 \mathrm{~cm}$., max. w $11.8 \mathrm{~cm}$., max. th $2.2 \mathrm{~cm}$.

Light reddish brown (5YR 6/4), unslipped surface both on exterior and interior. Average hardness; very sparsely porous, fine, reddish yellow (5YR 6/6) fabric with some lime as well as medium grit and sand inclusions.

$9^{\text {th }}$ cent. A.D.

112- ( $\left.\mathrm{N}^{\circ} 1269\right)$ : Rim fragment; Kimistene, Necropolis I, found in 2005 .

pl. $12 / 112$.

Max. h 4.9 cm., d of rim $28.6 \mathrm{~cm}$., max. w $15.4 \mathrm{~cm}$., $\max$. th $0.8 \mathrm{~cm}$. 

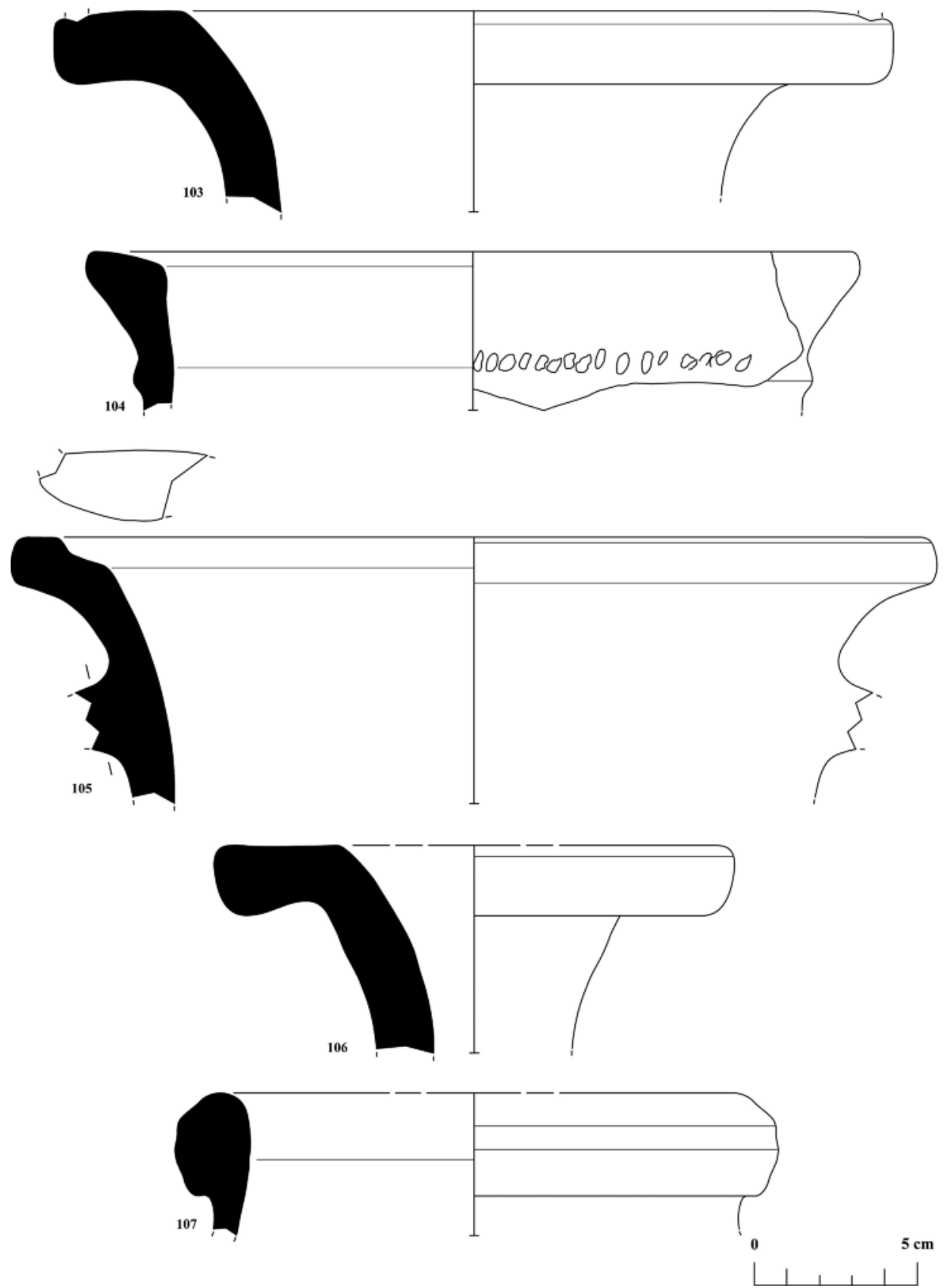

Pl. 11 : $\mathrm{N}^{\text {os }}$ 103-107 : Storage ware, rim fragments of pithoid vessels and pithoi. 

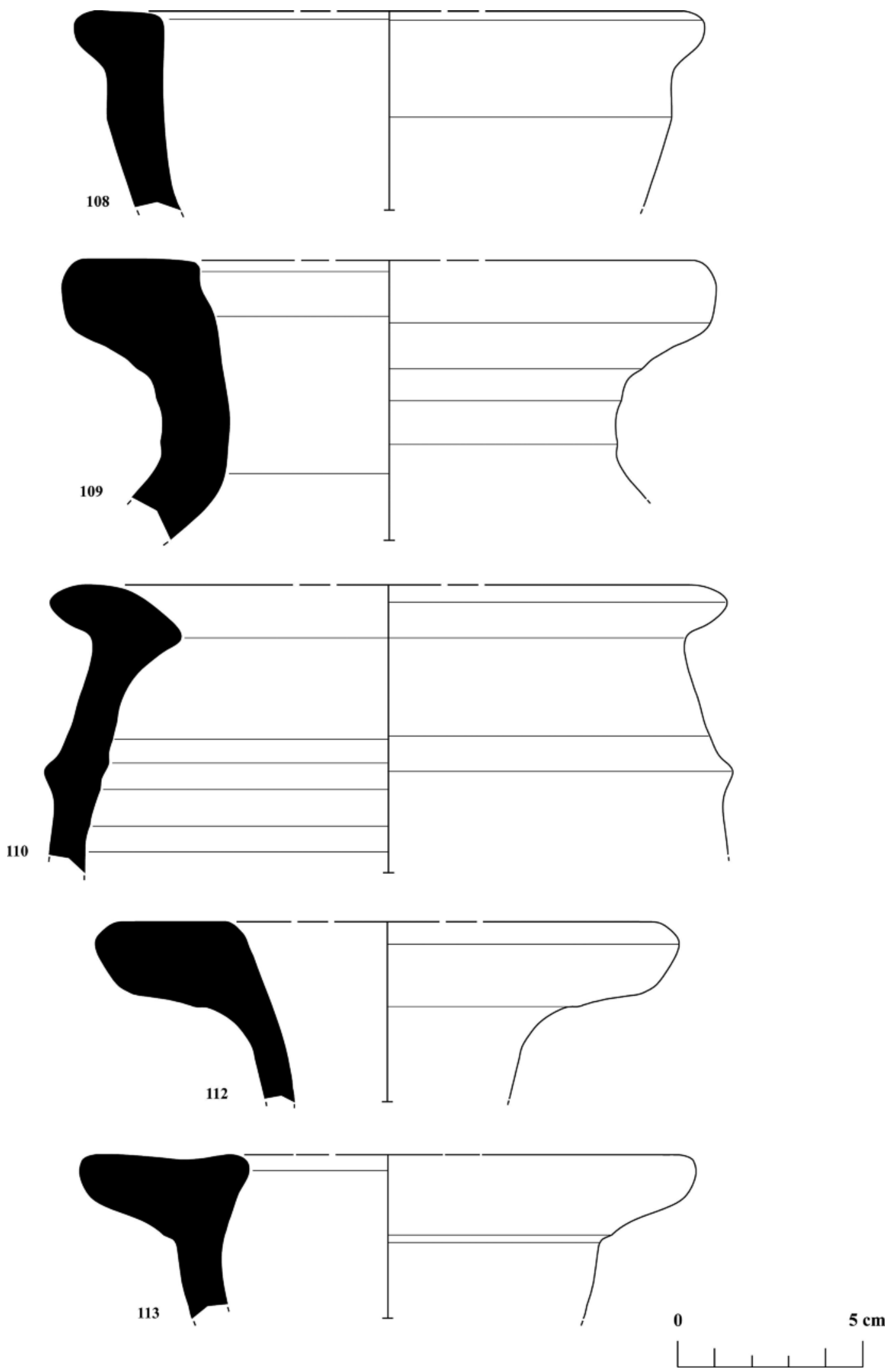

Pl. 12 : Nos 108-113 : Storage ware, rim fragments of pithoid vessels and pithoi. 
Reddish brown (5YR 5/3), unslipped surface on exterior; reddish brown (5YR 5/4), unslipped surface in interior. Hard paste; sparsely porous, reddish brown (5YR $4 / 3)$ and dark grey (5YR 4/1) mottled fabric with frequent lime and some medium grit inclusions.

$9^{\text {th }}$ cent. A.D.

113- ( $\left.\mathrm{N}^{\circ} 1303\right)$ : Rim fragment; Kimistene, Acropolis, found in 2005 .

2/113.

Max. h $4.4 \mathrm{~cm}$., d of rim $31.6 \mathrm{~cm}$., max. w $9.7 \mathrm{~cm}$., max. th $1.0 \mathrm{~cm}$.

Reddish yellow (5YR 6/6), unslipped surface on exterior; light brown (7.5YR 6/3), unslipped surface in interior. Hard paste; very sparsely porous, dark grey (7.5YR 4/1) fabric with frequent lime and some medium grit inclusions.

$9^{\text {th }}$ cent. A.D.

114- ( $\mathrm{N}^{\circ}$ 1382): Rim fragment; Kepez, necropolis, found in 2005 .

pl. 13/114.

Max. h $11.3 \mathrm{~cm}$. , d of rim $32.0 \mathrm{~cm}$., max. w $13.8 \mathrm{~cm}$., max. th $3.4 \mathrm{~cm}$.

Pink (7.5YR 7/4) slip on exterior; reddish yellow (5YR 6/6), unslipped surface in interior. Average hardness; very sparsely porous, fine, reddish yellow (5YR 6/6) fabric with frequent lime and some sand inclusions.

$9^{\text {th }}$ cent. A.D.

115- (№ 705): Rim fragment; Kimistene, Acropolis, temple's eastern slope, surface find, found in 2005.

pl. 13/115.

Max. h $3.9 \mathrm{~cm}$., d of rim $33.8 \mathrm{~cm}$., max. w $11.3 \mathrm{~cm}$., $\max$. th $2.4 \mathrm{~cm}$.

A form with a short neck and an incurved rim.

Red (2.5YR 5/6) slip on exterior; light reddish brown (5YR 6/4), unslipped surface in interior. Hard paste; nonporous, reddish yellow (5YR 6/6) and light brownish grey (10YR 6/2) mottled fabric with frequent tiny lime inclusions.

$9^{\text {th }}$ cent. A.D.

116- ( $\mathrm{N}^{\circ}$ 1383): Rim fragment; Kepez, necropolis, found in 2005 .

pl. 13/116.

Max. h $10.7 \mathrm{~cm}$., d of rim $33.8 \mathrm{~cm}$., max. w $16.4 \mathrm{~cm}$., $\max$. th $2.9 \mathrm{~cm}$.

Traces of carbon is visible on the rim.

Pink (7.5YR 7/4) slip on exterior; reddish yellow (7.5YR 7/6), unslipped surface in interior. Average hardness; non-porous, fine, pink (7.5YR 7/4) fabric with frequent medium grit and sand as well as rare tiny lime inclusions.

$10^{\text {th }}$ cent. A.D.
117- $\left(\mathrm{N}^{\circ}\right.$ 1445): Rim fragment; Kepez, necropolis, found in 2005.

pl. $13 / 117$.

Max. h $6.0 \mathrm{~cm}$., d of rim $36.2 \mathrm{~cm}$. , max. w $13.7 \mathrm{~cm}$., $\max$. th $2.2 \mathrm{~cm}$.

Very pale brown (10YR 7/3), unslipped surface both on exterior and interior. Hard paste; sparsely porous, fine, light brownish grey (10YR 6/2) fabric with frequent lime and large grit inclusions.

Late $9^{\text {th }}$-early $10^{\text {th }}$ cent. A.D.

118- ( $\left.\mathrm{N}^{\mathrm{o}} 1381\right)$ : Rim fragment ${ }^{90}$; Kepez, necropolis, found in 2005 .

pl. 14/118.

Max. h $15.1 \mathrm{~cm}$. , d of rim $36.2 \mathrm{~cm}$., max. w $22.3 \mathrm{~cm}$., max. th $2.5 \mathrm{~cm}$.

Applied cordon and finger pinched decoration. Traces of carbon is visible on the rim.

Reddish yellow (5YR 6/6) slip both on exterior and interior rim; light reddish brown (5YR 6/4), unslipped surface on upper interior. Hard paste; very sparsely porous, fine, reddish yellow (5YR 6/6) fabric with some lime as well as medium grit and sand inclusions.

Late $8^{\text {th }}$-early $9^{\text {th }}$ cent. A.D.

119- (№ 1443): Rim fragment; Kimistene, Acropolis, temple's terrace, found in 2005 .

pl. 14/119.

Max. h $9.5 \mathrm{~cm}$., d of rim $41.6 \mathrm{~cm}$., max. w $10.8 \mathrm{~cm}$., max. th $2.0 \mathrm{~cm}$.

Light reddish brown (5YR 6/4), unslipped surface both on exterior and interior. Average hardness; porous, fine, light reddish brown (5YR 6/4) fabric with frequent lime and some medium grit inclusions.

$9^{\text {th }}$ cent. A.D.

120- ( $\left.\mathrm{N}^{\circ} 1287\right)$ : Rim fragment; Kimistene, Acropolis, temple's terrace, found in 2005.

pl. 14/120.

Max. h $4.0 \mathrm{~cm}$., d of rim $43.0 \mathrm{~cm}$., max. w $11.4 \mathrm{~cm}$., $\max$. th $2.2 \mathrm{~cm}$.

Very pale brown (10YR 7/3), unslipped surface both on exterior and interior. Average hardness; very sparsely porous, fine, pale brown (10YR 6/4) fabric with some medium grit and sand as well as rare tiny lime and grog inclusions.

Late $8^{\text {th }}$-early $9^{\text {th }}$ cent. A.D.

121- ( $\mathrm{N}^{\mathrm{o}}$ 1405): Rim fragment; from the district of Emiroğlu, surface find, found in 2005.

pl. 14/121.

Max. h $7.5 \mathrm{~cm}$. , d of rim $57.0 \mathrm{~cm}$., max. w $16.4 \mathrm{~cm}$., $\max$. th $2.8 \mathrm{~cm}$.

A large rim form ${ }^{91}$.

90) A similar rim fragment from Hierapolis: Ruggiu and Cottica 2007: 175, fig. 11 (Middle Byzantine period); and Tahir(ler): $<$ https://content.lib.washington.edu/cdm4/item viewer.php?CISOROOT=/tahirler\&CISOPTR=544\&CISOBOX=1\&REC $=12>(20 / 09 / 2015)$ (Middle Byzantine period).

91) A similar rim profile from Amorium: Lightfoot 2007: 278, figs. 8-9. 

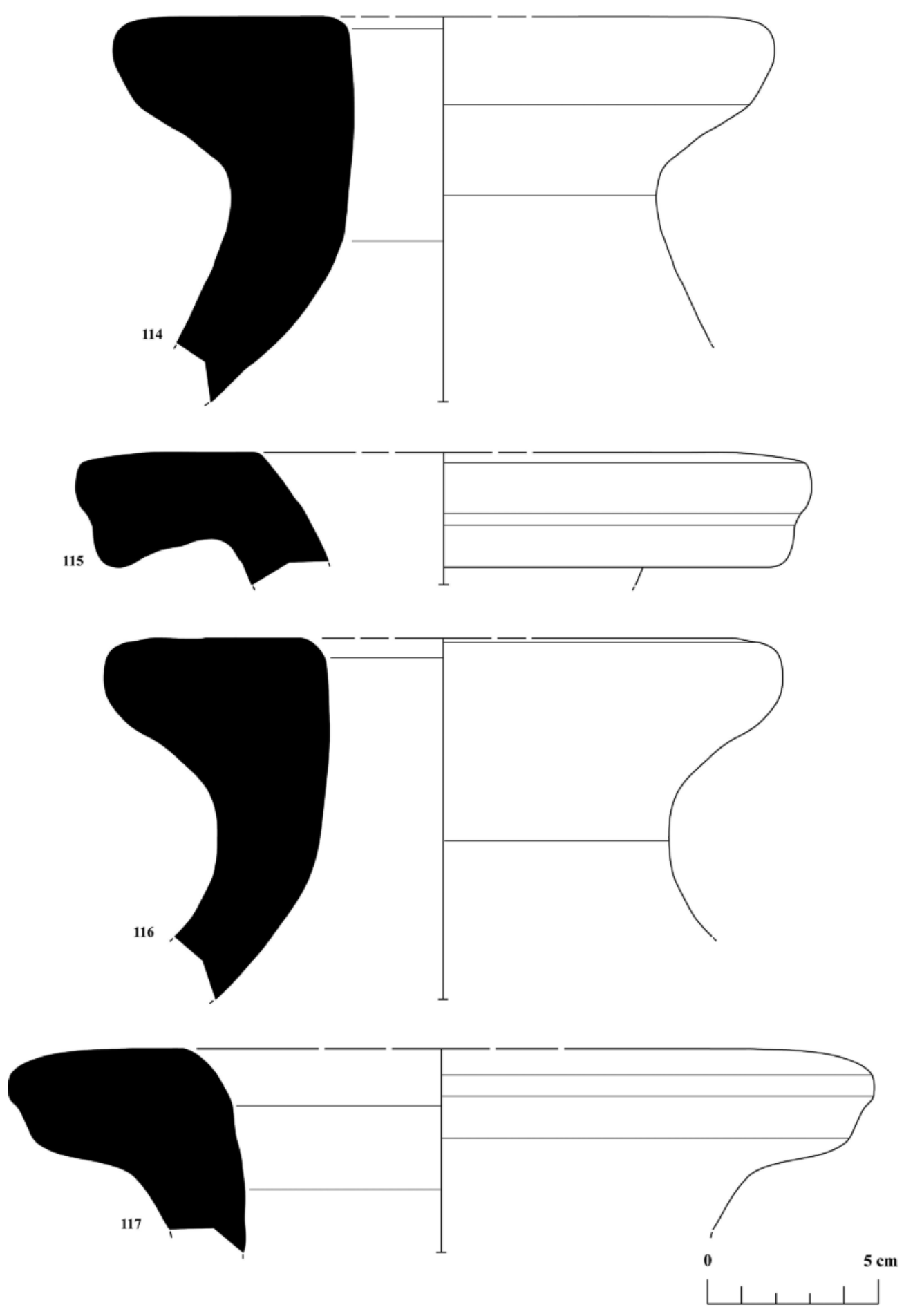

Pl. 13 : Nos 114-117 : Storage ware, rim fragments of pithoid vessels and pithoi. 

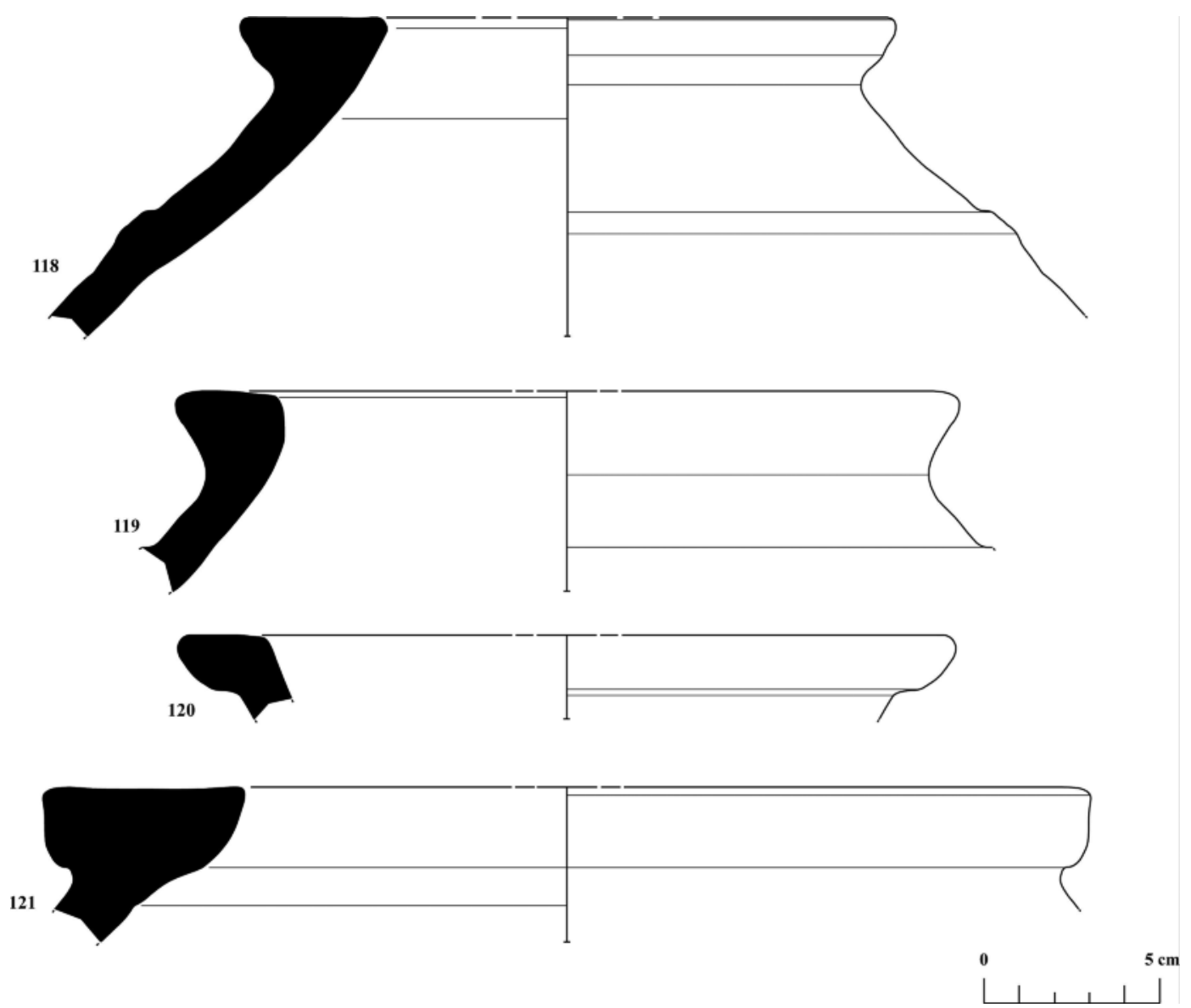

Pl. 14 : Nos 118-121 : Storage ware, rim fragments of pithoid vessels and pithoi.

Light reddish brown (10YR 6/4) slip on exterior; reddish yellow (5YR 6/6), unslipped surface in interior. Average hardness; very sparsely porous, reddish yellow (5YR 6/6) fabric with frequent medium grit and rare mica inclusions.

Late $8^{\text {th }}$-early $9^{\text {th }}$ cent. A.D.

\section{Transport Ware}

(pls. 15-16, $\mathrm{n}^{\mathrm{os}} 122-130$ )

During the Middle Byzantine period the most important transport vessel in southwestern Paphlagonia was amphora that generally thought to have contained wine, olive oil or fish products, and was mainly used for long-distance transports ${ }^{92}$. As in Amorium ${ }^{93}$, also in southwestern Paphlagonia our find assemblages of amphorae is very small and fragmentary, although some Middle Byzantine amphorae are known from Paphlagonian coastal sites ${ }^{94}$. In Sinope or other major centres on the southern coast of the Black Sea there should definitely had been an amphora workshop that is likely to be dated to the first half of the $13^{\text {th }}$ cent. A.D. ${ }^{95}$. Because of the absence of complete vessels the fragments do not allow any detailed typological classification; some generalisations, however, can still be made: Most of their lips are round; their handles are attached on a conical and long neck. Wheel ridges begin below the lower handle attachments; two fingers made grooves run down the outer surface of the handles. Their surfaces are coated or smooth. The fabric of amphorae changes from red to yellow and brown. They have generally a hard and very porous fabric. Their surfaces contain sand and grit inclusions.

92) Kaptijn et al. 2013: 88; as well as for their primarily use and other functions $c f$. Peña 2007: 61-192.

93) Lightfoot and Ivison 1996: 97.

94) For a detailed discussion on the transport of commodities of the Paphlagonian coastal sites and the Black Sea: Brubaker and Haldon 2011: 520. Byzantine amphorae associated with Amastris were found in quantities along the northern Pontic coast, although the commodities they were carring are not certain yet (oil or nuts?).

95) Collins 2012: 30; as well as Zelenko 2008: 130-131, 161 and 163-164 <http://archaeology.kiev.ua/journal/030500/zelenko.htm>; $<$ http://users.stlcc.edu/mfuller/Area11artifactsPottery.html $>(20 / 09 / 2015)$. 
122- ( $\mathrm{N}^{\mathrm{o}} 261$ ): Rim fragment; western tomb, found in 2007.

pl. $15 / 122$.

Max. h $5.3 \mathrm{~cm}$., d of rim $3.8 \mathrm{~cm}$., max. w $5.6 \mathrm{~cm}$, $\max$ th $0.6 \mathrm{~cm}$.

The surface is plain and burnished.

Red (2.5YR 5/6) slip on exterior; light red (2.5YR $6 / 6)$, unslipped surface in interior. Hard paste; very sparsely porous, fine, reddish yellow (5YR 6/6) fabric with frequent lime and sand inclusions.

$9^{\text {th }}$ cent. A.D.

123- ( $\mathrm{N}^{\circ}$ 1124): Rim fragment; Kimistene, Acropolis, found in 2005 .

pl. $15 / 123$.

Max. h $5.9 \mathrm{~cm}$., d of rim $5.4 \mathrm{~cm}$., max. w $6.0 \mathrm{~cm}$., max. th $0.6 \mathrm{~cm}$.

Reddish yellow (7.5YR 7/6), unslipped surface both on exterior and interior. Hard paste; non-porous, fine, reddish yellow (7.5YR 6/6) fabric with some sand inclusions.

Late $8^{\text {th }}$-early $9^{\text {th }}$ cent. A.D.

124- (No 873): Rim fragment; Kimistene, Acropolis, southern slope, underground cave, surface find, found in 2005 .

pl. $15 / 124$.

Max. h $5.8 \mathrm{~cm}$., d of rim $6.4 \mathrm{~cm}$., max. w $6.6 \mathrm{~cm}$., $\max$ th $0.7 \mathrm{~cm}$.

Reddish yellow (5YR 6/6) slip on exterior; reddish yellow (5YR 7/6), unslipped surface in interior. Hard paste; non-porous, fine, reddish yellow (5YR 6/6) fabric with some tiny lime and rare mica inclusions.

$9^{\text {th }}$ cent. A.D.

125- (No 1257): Rim fragment; Kimistene, Necropolis I, surface find, found in 2005.

pl. 15/125.

Max. h $3.7 \mathrm{~cm}$., d of rim $7.2 \mathrm{~cm}$., max. w $6.3 \mathrm{~cm}$., $\max$. th $0.5 \mathrm{~cm}$.

Light brown (7.5YR 6/4), unslipped surface on exterior; reddish yellow (7.5YR 6/6), unslipped surface in interior. Hard paste; non-porous, fine, brown (7.5YR $4 / 3$ ) fabric with occasional tiny lime inclusions.

$10^{\text {th }}$ cent. A.D.

126- ( $\mathrm{N}^{\mathrm{o}}$ 597): Rim fragment ${ }^{96}$; Bath $\mathrm{A}$, room 10 , found in 2006 .

pl. $15 / 126$.

Max. h $9.0 \mathrm{~cm}$., d of rim $7.4 \mathrm{~cm}$., max. w $12.3 \mathrm{~cm}$., $\max$. th $1.8 \mathrm{~cm}$.
Short neck, short and heavy handle, convex body and wide bands/ridges below rim.

Pink (7.YR 7/4), unslipped surface on exterior; reddish yellow (5YR 7/6), unslipped surface in interior. Hard and thin paste; non-porous, fine, reddish yellow (5YR 6/6) fabric with frequent tiny lime inclusions.

Similar shapes were found in the area between Gaziköy and Hoşköy in Marmara (classical Propontis) ${ }^{97}$, on the shore of Danube's mouth into the Black Sea ${ }^{98}$, Saraçhane ${ }^{99}$, Demre ${ }^{100}$ and Laspi ${ }^{101}$. In Ganos this type of amphorae is named as 'Günsenin Type 1' and is dated to the $9^{\text {th }}-11^{\text {th }}$ cent. A.D. ${ }^{102}$.

127- ( $N^{\circ} 979$ ): Rim fragment; from the field surveys in Hadrianoupolis, surface find, found in 2005.

pl. 16/127.

Max. h $5.5 \mathrm{~cm}$., d of rim $7.8 \mathrm{~cm}$., max. w $6.2 \mathrm{~cm}$., $\max$. th $0.4 \mathrm{~cm}$.

Exterior is burnished.

Light brown (7.5YR 6/4), unslipped surface both on exterior and interior. Hard paste; very sparsely porous, red (2.5YR 5/6) fabric with some sand and tiny lime inclusions.

$10^{\text {th }}$ cent. A.D.

128- ( $\left.\mathrm{N}^{\circ} 816\right)$ : Rim fragment; Kimistene, summit of the Acropolis, western slope, found in 2005.

pl. $16 / 128$.

Max. h $4.6 \mathrm{~cm}$., d of rim $11.4 \mathrm{~cm}$., max. w $8.7 \mathrm{~cm}$., $\max$. th $0.8 \mathrm{~cm}$.

Handle is attached to the neck. Two horizontal grooves under the neck.

Greyish brown (10YR 5/2) slip both on exterior and interior rim; dark greyish brown (10YR 4/2), unslipped surface on lower interior. Hard paste; non-porous, fine, dark greyish brown (10YR 4/2) fabric with some sand inclusions.

Early $10^{\text {th }}$ cent. A.D.

129- (No 1363): Rim fragment; Kimistene, Acropolis, found in 2005 .

pl. $16 / 129$.

Max. h $5.3 \mathrm{~cm}$., d of rim $12.4 \mathrm{~cm}$., max. w $6.0 \mathrm{~cm}$., $\max$. th $0.8 \mathrm{~cm}$.

An outturned and slightly thickened rim with perhaps a long and conical neck.

Reddish yellow (5YR 6/6), unslipped surface both on exterior and interior. Hard paste; very sparsely porous, fine, reddish yellow (5YR 6/8) fabric with occasional tiny lime inclusions.

Early $10^{\text {th }}$ cent. A.D.

96) For a similar rim profile: Mimaroğlu 2010: 444-445, pl. 1, no 1.

97) Günsenin 1993: 194-196; and Mimaroğlu 2010: 445.

98) Todorova 2011: 134 .

99) Hayes 1992: 73-74.

100) Türker 2006: 161.

101) Parshina 2001: 113-114.

102) Mimaroğlu 2010: 445; 2011: 71, fig. 3; and Türker 2005: 97. This type has also been found in Thessaloniki, Crimea, Laspi, Ukraine and elsewhere. 

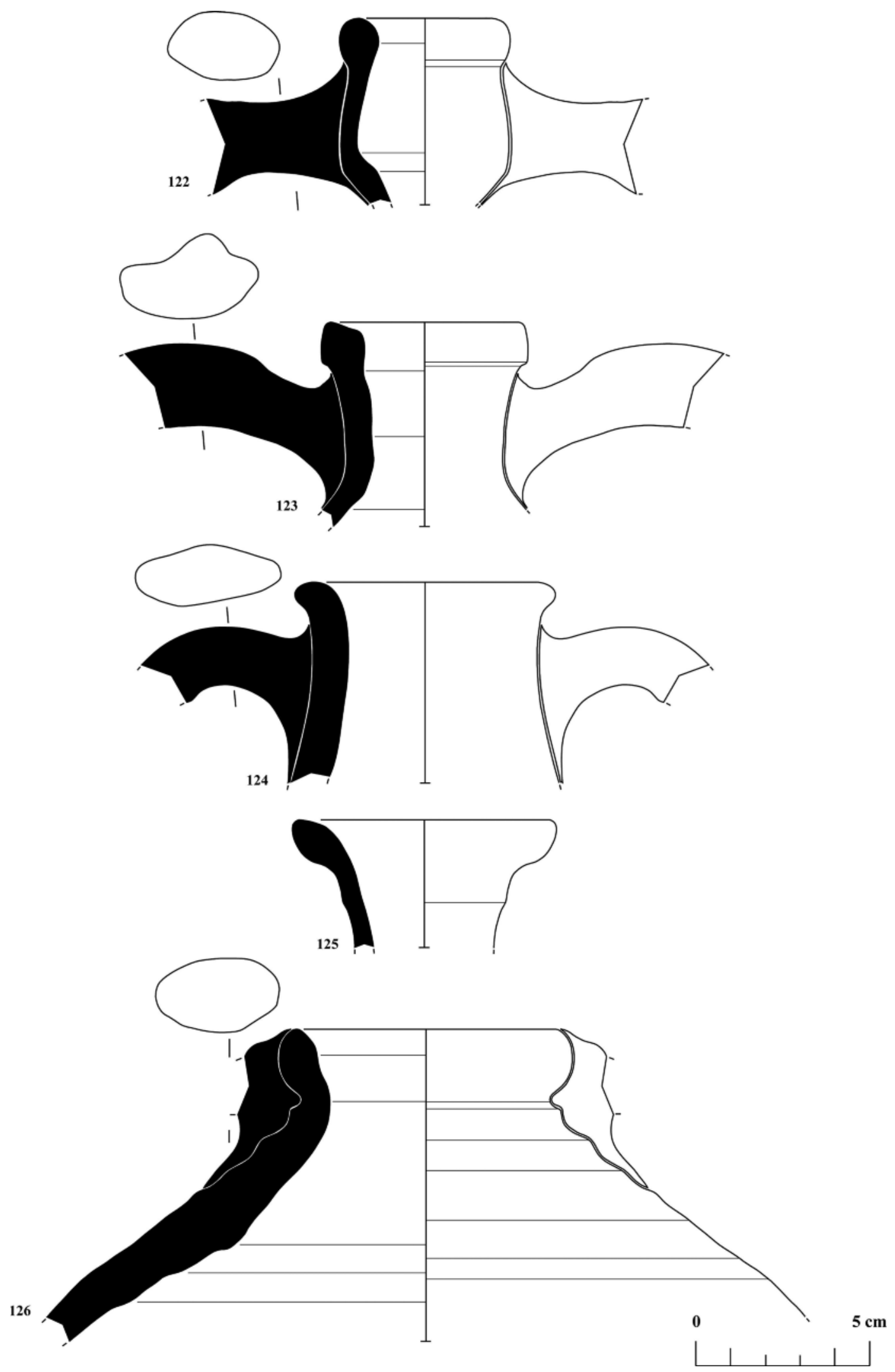

Pl. 15 : $\mathrm{N}^{\text {os }} 122-126$ : Transport ware, fragments of amphorae. 
130- ( $\mathrm{N}^{\mathrm{o}}$ 965): Rim fragment; Kimistene, surface find from the cistern, eastern slope, found in 2005.

pl. 16/130.

Max. h $4.9 \mathrm{~cm}$., d of rim $12.6 \mathrm{~cm}$., max. w $4.8 \mathrm{~cm}$., $\max$. th $0.6 \mathrm{~cm}$.

There is an incised wavy line between two ridges on the neck. The rest of the surface is plain. Its handle is attached between the rim and neck.

Greyish brown (10YR 5/2) slip on exterior; pale brown (10YR 6/3), unslipped surface in interior. Hard paste; non-porous, grey (10YR 5/1) and greyish brown (10YR 5/2) mottled fabric with frequent grit and some lime inclusions.

$10^{\text {th }}$ cent. A.D.

\section{Miscellaneous Coarse Vessel Fragments (pls. 16-19, $\mathrm{n}^{\text {os }} 132-207$; pls. 23-29, $\mathrm{n}^{\text {os }} 131-261$ )}

This group, mostly domestic vessel fragments, comprises of a lid, base, handle and body fragments of closed and unknown shapes. A fragment of a terracotta spindle whorl has been added to this group.

\section{A Lid Fragment \\ (pl. 23, $\left.\mathrm{n}^{\circ} 131\right)$}

Compared to the Early Byzantine period, lid fragments are rare in the Middle Byzantine period. R. Smadar Gabrieli comments about a similar case at Kata Paphos on Medieval Cyprus ${ }^{103}$. Storage vessels could had a variety of non-pottery covers, such as stone-slabs or wood which are still being used today; but in southwestern Paphlagonia the lack of pottery lids for cooking pots is surprising.

131- ( $\mathrm{N}^{\mathrm{o}} 822$ ): Lid fragment; Kimistene, summit of the Acropolis, western slope, found in 2005.

pl. 23/131.

Max. $111.1 \mathrm{~cm}$., max. w $5.9 \mathrm{~cm}$., max. th $1.7 \mathrm{~cm}$.

Pink (7.5YR 7/4), unslipped surface both on exterior and interior. Hard paste; very sparsely porous, fine, light brown (7.5YR 6/4) fabric with frequent tiny lime and small grit inclusions.

Early $10^{\text {th }}$ cent. A.D.

\section{A Fragment of a Spindle Whorl (pl. 16, $\mathrm{n}^{\circ} 132$ )}

It is a terracotta discoid, spherical object fitted onto the spindle to increase and maintain the speed of the spin. In Middle Byzantine Asia Minor whorls had been made of many different materials: antler, bone, glass, metals (iron, lead, lead and alloy), wood (especially oak), chalk, limestone, mudstone, sandstone and soapstone. Very few spindle whorls were found in a well-dated archaeological context though ${ }^{104}$.

132- ( $\mathrm{N}^{\circ} 589$ ): Spindle whorl; Kimistene, summit of the Acropolis, western slope, found in 2005.

pl. 16/132.

Max. $13.3 \mathrm{~cm}$., max. w $3.0 \mathrm{~cm}$., max. th $1.1 \mathrm{~cm}$. Light brown (7.5YR 6/4), unslipped surface both on exterior and interior. Hard paste; very sparsely porous, light brown (7.5YR 6/4) fabric with some tiny lime and small quartz inclusions

Late $9^{\text {th }}$ cent. A.D.

\section{Base Fragments of Undetermined Closed Forms (pls. 16-17, $\mathrm{n}^{\text {os }} 133-141$ )}

Some of them are flat (pls. 16-17, $\mathrm{n}^{\text {os }} 133-135,137-$ 138 and 141) or ring bases (pl. 17, $\mathrm{n}^{\text {os }} 136$ and 141), even though flat bases have externally not been distinguished from the lower part of the vessels. $\mathrm{N}^{\circ} 136$ on pl. 17 approximates a ring foot. Similar forms were found at Alexandria of the Troad ${ }^{105}$. C. Bakirtzis argued in 1989 that Byzantine cooking pots with flat bottoms were associated with a rural way of life, whereas round-bottomed pots reflect an urban setting ${ }^{106}$.

133- ( $\left.\mathrm{N}^{\circ} 805\right)$ : Base fragment; Kimistene, summit of the Acropolis, western slope, found in 2005.

pl. $16 / 133$.

Max. h $1.3 \mathrm{~cm}$., d of base $5.0 \mathrm{~cm}$., max. w $5.0 \mathrm{~cm}$., max. th $0.5 \mathrm{~cm}$.

Brown (7.5YR 4/3) slip on exterior; brown (7.5YR $4 / 2$ ), unslipped surface in interior. Average hardness; non-porous, brown (7.5YR 4/2) fabric with mica inclusions.

134- ( $\mathrm{N}^{\mathrm{o}} 368$ ): Base fragment; Bath $\mathrm{B}$, room 8 , found in 2007.

pl. $16 / 134$.

Max. h $1.3 \mathrm{~cm}$., d of base $8.0 \mathrm{~cm}$., max. w $3.9 \mathrm{~cm}$., max. th $0.5 \mathrm{~cm}$.

Very dark grey (10YR 3/1) slip on exterior; brown (7.5YR 5/2), unslipped surface in interior. Average hardness; non-porous, very dark grey (10YR 3/1) fabric with some tiny lime inclusions.

135- ( $\left.\mathrm{N}^{\circ} 815\right)$ : Base fragment ${ }^{107}$; Kimistene, summit of the Acropolis, western slope, found in 2005.

103) Gabrieli 2008: 426.

104) A similar object of a personal adornment was found at Amorium: Ivison 2012: 57. Hemispheroid spindle whorls without any decoration were found in Byzantine levels of Kilise Tepe in Cilicia: Symington and Collon 2007: 496.

105) A similar flat base with a diagonal body: Japp 2010: 69, $\mathrm{n}^{\circ}$ 48. A further similar example: Hayes 1992: 144, $\mathrm{n}^{\circ} 5 ; 147, \mathrm{n}^{\circ} 13$.

106) Bakirtzis 1989: 41; and Vionis et al. 2010: 457.

107) A similar base profile from Amorium: Böhlendorf-Arslan 2012: 155, fig. 2.5 (late $8^{\text {th }}$-early $9^{\text {th }}$ cent.). 

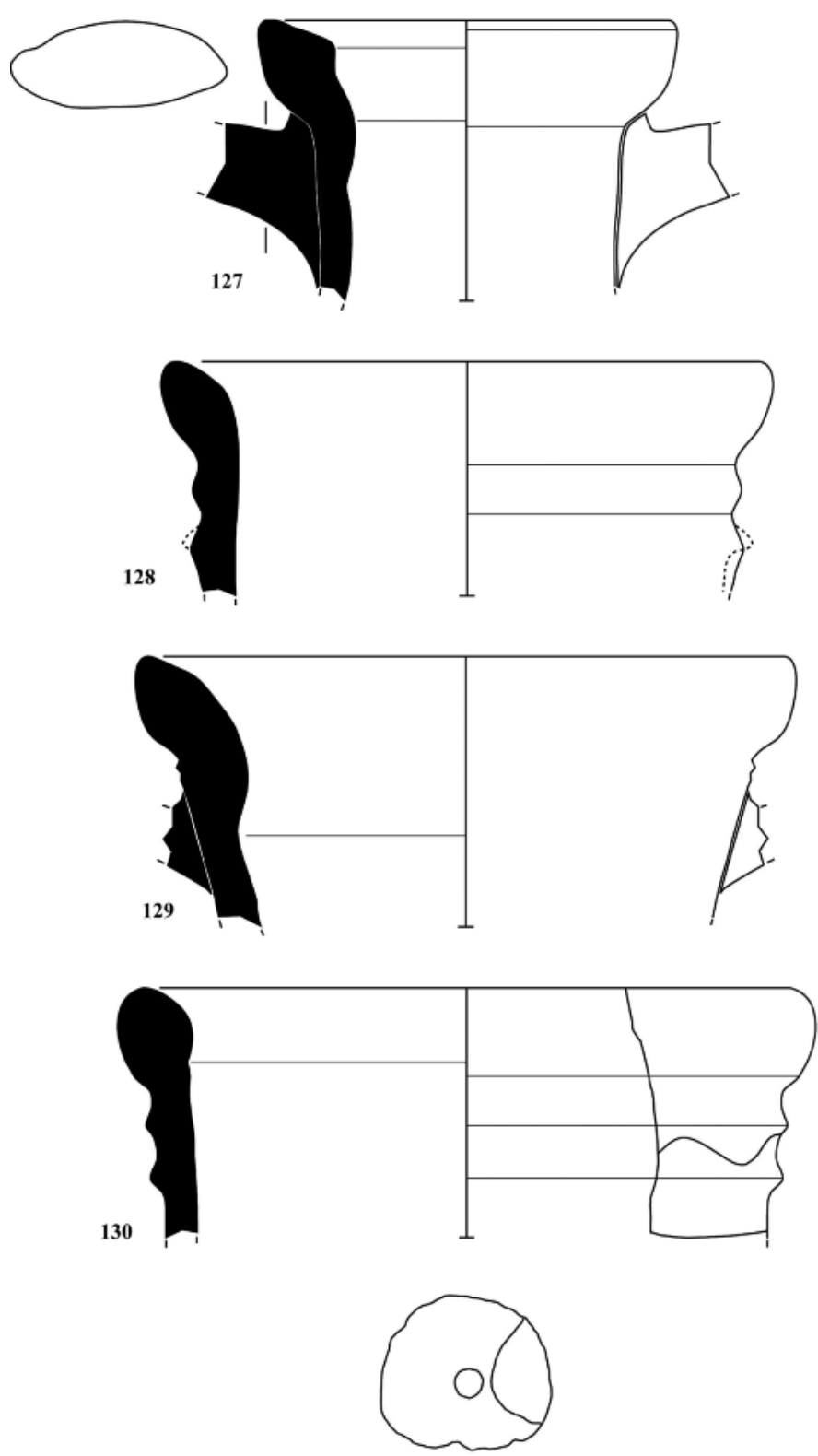

132
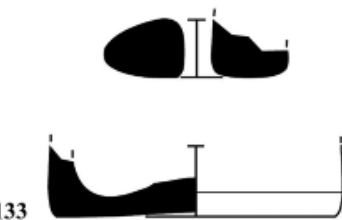

133
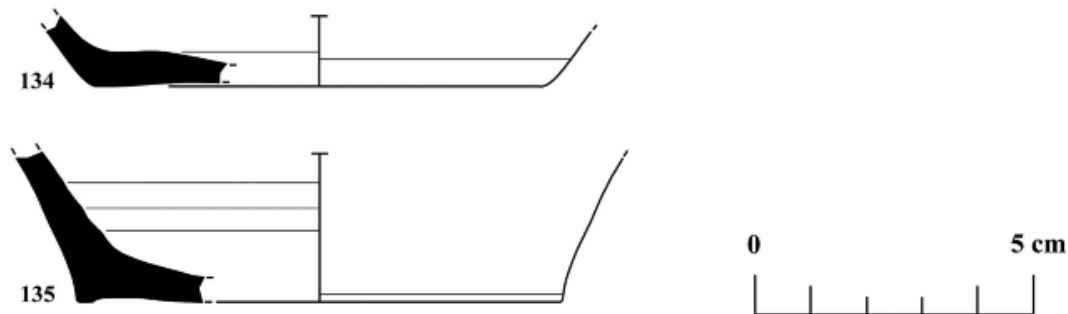

Pl. 16 : Nos $127-130$ : Transport ware, fragments of amphorae; $\mathbf{n}^{\text {os }} 132-135$ : Miscellaneous coarse vessel fragments; $n^{0}$ 132: A fragment of a spindle whorl;

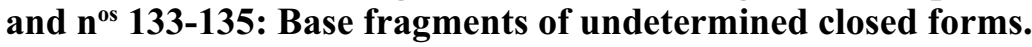


pl. $16 / 135$.

Max. h $2.7 \mathrm{~cm}$., d of rim $8.6 \mathrm{~cm}$., max. w $7.4 \mathrm{~cm}$., max. th $0.5 \mathrm{~cm}$.

Flat base. Exterior is blackened.

Light reddish brown (5YR 6/4), unslipped surface on exterior; light reddish brown (5YR 6/3), unslipped surface in interior. Average hardness; very sparsely porous, light reddish brown (5YR 6/4) fabric with frequent lime and medium grit inclusions.

136- ( $\mathrm{N}^{\circ}$ 1342): Base fragment; Kimistene, cistern, eastern slope, found in 2005.

pl. $17 / 136$.

Max. h $2.0 \mathrm{~cm}$., d of rim $12.0 \mathrm{~cm}$., max. w $6.8 \mathrm{~cm}$., $\max$ th $1.1 \mathrm{~cm}$.

Exterior is blackened.

Grey (10YR 6/1), unslipped surface both on exterior and interior. Hard paste; non-porous, fine, dark greyish brown (10YR 4/2) fabric with some tiny lime and sand inclusions.

137- ( $\left.\mathrm{N}^{\circ} 79\right)$ : Base fragment; Bath $\mathrm{B}$, room 3, found in 2007.

pl. $17 / 137$.

Max. h $3.7 \mathrm{~cm}$., d of base $12.0 \mathrm{~cm}$., max. w $9.3 \mathrm{~cm}$., max. th $0.7 \mathrm{~cm}$.

Light yellowish brown (10YR 6/4), unslipped surface on exterior; greyish brown (10YR 5/2), unslipped surface in interior. Hard paste; non-porous, dark grey (10YR 4/1) fabric with occasional sand and rare mica inclusions.

138- ( $\mathrm{N}^{\circ}$ 462): Base fragment; Kimistene, Acropolis, southern slope, just below the summit, towards Deresemail creek, found in 2005 .

pl. 17/138.

Max. h $1.9 \mathrm{~cm}$., d of rim $12.2 \mathrm{~cm}$., max. w $6.2 \mathrm{~cm}$., max. th $0.4 \mathrm{~cm}$.

Reddish yellow (5YR 6/6) slip on exterior; light red (2.5YR 6/6), unslipped surface in interior. Hard paste; very sparsely porous, fine, light red $(2.5 \mathrm{YR} 6 / 6)$ fabric with some tiny lime inclusions.

139- $\left(\mathrm{N}^{\circ} 1380\right)$ : Base fragment ${ }^{108} ;$ Kepez, necropolis, found in 2005 .

pl. $17 / 139$.

Max. h $6.0 \mathrm{~cm}$., d of base $12.8 \mathrm{~cm}$., max. w $14.9 \mathrm{~cm}$., max. th $1.1 \mathrm{~cm}$.

A flat base and diagonal body wall.

Very pale brown (10YR 7/4) slip on exterior; light grey (10YR 7/2), unslipped surface on exterior. Average hardness; non-porous, fine, very pale brown (10YR 7/4) fabric with some tiny lime inclusions.

140- ( $\mathrm{N}^{\circ}$ 1251): Base fragment; Kimistene, western slope of the temenos, found in 2005.

pl. 17/140.

Max. h $4.2 \mathrm{~cm}$., d of rim $15.4 \mathrm{~cm}$., max. w $14.1 \mathrm{~cm}$., $\max$. th $1.7 \mathrm{~cm}$.

Light reddish brown (5YR 6/4) slip on exterior; pink (5YR 7/4), unslipped surface in interior. Hard paste; very sparsely porous, fine, reddish yellow (5YR 6/6) fabric with some tiny lime and sand inclusions.

141- ( $\mathrm{N}^{\circ} 710$ ): Base fragment; Kimistene, Acropolis, temple's eastern slope, surface find, found in 2005.

pl. $17 / 141$.

Max. h $7.5 \mathrm{~cm}$., d of rim $18.4 \mathrm{~cm}$., max. w $10.3 \mathrm{~cm}$., $\max$. th $1.4 \mathrm{~cm}$.

Wet smoothing marks on interior.

Light red (2.5YR 6/6) slip on exterior; pink (5YR 7/4) slip on interior. Hard paste; non-porous, fine, pink (5YR 7/4) fabric with some tiny lime and sand inclusions.

\section{Handle Fragments of Undetermined Closed Forms \\ (pls. 17-18, nos 145-172; pls. 23-24, $\mathrm{n}^{\text {os }} 142-171$ )}

Most of the handles were attached from shoulder to rim or rising high above rim. Some thick-walled vessels have a ridged or grooved handle. Some small handles (pls. 17, 23, $\mathrm{n}^{\text {os }} 142-146$ ) may belong to one handled jugs. $\mathrm{N}^{\text {os }} 148-150$ on pl. 23 and $\mathrm{n}^{\text {os }} 154-156$ on pls. 18 and 23 have a vertical and oval form ${ }^{109}$. Some others have a round cross-section or strap form. Handles of some amphorae, flagons or jars feature single or double rows, or irregular series of holes that had been opened with a sharp and pointy tool ${ }^{110}$. Some of them are featuring sharp and pointy tool decorations (pls. 18 and 23, $\left.\mathrm{n}^{\text {os }} 157-160\right)^{111}$ or vertical impressed decoration irregular to each other ${ }^{112}$.

142- ( $\mathrm{N}^{\mathrm{o}}$ 1049): Handle fragment; Kepez, found in 2005.

pl. 23/142.

Max. h $2.4 \mathrm{~cm}$. , max. w $2.4 \mathrm{~cm}$., max. th $0.6 \mathrm{~cm}$

Light brown (7.5YR 6/4), unslipped surface both on exterior and interior. Soft paste; non-porous, fine, yellowish red $(5$ YR 5/6) fabric with frequent tiny lime inclusions.

108) Similar base profiles: Arthur 2012: 283, fig. 10, $\mathrm{n}^{\mathrm{o}} 5$ (10 th $^{\text {th }}$ cent.?); and Japp 2010: 69, fig. $9, \mathrm{n}^{\circ} 49$.

109) Typologically they are similar to LR1 amphorae, small jug or jug handles from Elaeousa-Sebaste in Cilicia: Ferrazzoli and Ricci 2010a: 817, figs. 18-20; as well as Ferrazzoli and Ricci 2010b: 804, fig. 2.13 and fig. 2.16 (late $5^{\text {th }}-6^{\text {th }}$ cent. A.D.).

110) Similar handle fragments from Tripolis: Duman 2014: 226, fig. $3, \mathrm{n}^{\text {os }} 8,15,17$ and $20-22$ (third quarter of the $10^{\text {th }}$ cent.-first quarter of the $11^{\text {th }}$ cent. A.D.).

111) Also at Tripolis: Duman 2014: 230, fig. 3, $\mathrm{n}^{\text {os }} 20-22$.

112) A similar Middle Byzantine fragment from Caria: De Staebler 2012: 72, fig. 15 ( $9^{\text {th }}-12^{\text {th }}$ cent. A.D.). 
143- ( $\mathrm{N}^{\circ}$ 819): Handle fragment; Kimistene, summit of the Acropolis, western slope, found in 2005.

pl. $23 / 143$.

Max. $13.2 \mathrm{~cm}$., max. w $2.5 \mathrm{~cm} .$, max. th $1.0 \mathrm{~cm}$.

Grey (10YR 5/1), unslipped surface both on exterior and interior. Hard paste; very sparsely porous, greyish brown (10YR 5/2) fabric with some sand and tiny lime inclusions.

144- (№ 1341): Handle fragment; Kimistene, Acropolis, southern slope, just below the summit, towards Deresemail creek, found in 2005 .

pl. 23/144.

Max. $14.2 \mathrm{~cm}$., max. w $2.8 \mathrm{~cm}$., max. th $1.2 \mathrm{~cm}$.

Light reddish brown (5YR 6/4), unslipped surface both on exterior and interior. Hard paste; non-porous, fine, reddish brown (5YR 6/6) fabric with some tiny lime inclusions.

145- ( $\left.N^{\circ} 970\right)$ : Handle fragment; Kimistene, cistern, eastern slope, surface find, found in 2005.

pl. 17/145.

Max. h $3.8 \mathrm{~cm}$., max. w $4.2 \mathrm{~cm}$., max. th $1.3 \mathrm{~cm}$.

Reddish yellow (5YR 6/6), unslipped surface both on exterior and interior. Hard paste; very sparsely porous, greyish brown (10YR 5/2) and brown (10YR 5/3) mottled fabric with some sand and tiny lime inclusions.

146- (No 975): Handle fragment; Kimistene, cistern, eastern slope, surface find, found in 2005.

pl. 17/146.

Max. h $6.3 \mathrm{~cm}$., max. w $4.4 \mathrm{~cm}$., $\max$. th $1.5 \mathrm{~cm}$.

Light brown (7.5YR 6/4), unslipped surface both on exterior and interior. Soft paste; non-porous, light brown (7.5YR 6/4) fabric with occasional medium grit inclusions.

147- ( $\left.\mathrm{N}^{\circ} 255\right)$ : Handle fragment; western tomb, found in 2007.

pl. 23/147.

Max. $15.4 \mathrm{~cm}$., max. w $2.5 \mathrm{~cm}$., max. th $1.9 \mathrm{~cm}$.

Carbon on exterior.

Red (2.5YR 4/6) slip on exterior; red (2.5YR 5/6), unslipped surface in interior. Average hardness; nonporous, fine, red $(2.5 \mathrm{YR} 5 / 8)$ fabric with frequent mica and sand inclusions.

148- ( No 703): Handle fragment; Kimistene, Acropolis, temple's eastern slope, surface find, found in 2005.

pl. $23 / 148$.

Max. $16.3 \mathrm{~cm}$., max. w $4.5 \mathrm{~cm}$., max. th $2.5 \mathrm{~cm}$.

Red (2.5YR 5/6) slip both on exterior and interior. Hard paste; non-porous, fine, light red (2.5YR 6/6) fabric with fabric with some tiny lime and mica inclusions.

149- (№ 711): Handle fragment; Kimistene, Acropolis, temple's eastern slope, surface find, found in 2005. pl. $23 / 149$.

Max. $17.7 \mathrm{~cm}$., max. w $2.8 \mathrm{~cm}$., max. th $2.8 \mathrm{~cm}$.

Reddish yellow (5YR 6/6), unslipped surface both on exterior and interior. Hard paste; non-porous, light red (2.5YR 6/6) fabric with some tiny lime and sand inclusions.

150- ( $\left.\mathrm{N}^{\circ} 451\right)$ : Handle fragment; Kimistene, Acropolis, southern slope, just below the summit, towards Deresemail creek, found in 2005 .

pl. 23/150.

Max. h 4.5 cm., max. w 5.9 cm., max. th $2.3 \mathrm{~cm}$.

Handle is attached horizontally on body.

Brown (7.5YR 6/4) slip on exterior; light brown (7.5YR 6/4), unslipped surface in interior. Hard and thin paste; non-porous, fine, reddish yellow (7.5YR 6/6) fabric with some grit and rare mica inclusions.

151- $\left(\mathrm{N}^{\circ} 88\right)$ : Handle fragment; Bath $\mathrm{B}$, room 5, found in 2007.

pl. $23 / 151$.

Max. $18.1 \mathrm{~cm}$., max. w $4.9 \mathrm{~cm}$., max. th $0.8 \mathrm{~cm}$.

Exterior is burnished.

Reddish yellow (5YR 6/6) slip on exterior; reddish brown (5YR 5/3), unslipped surface in interior. Hard paste; very sparsely porous, fine, light reddish brown (5YR 6/4) fabric with frequent tiny lime and large grit inclusions.

152- ( $\left.\mathrm{N}^{\circ} 1121\right)$ : Handle fragment; Acropolis, found in 2005 .

pl. $17 / 152$.

Max. $14.6 \mathrm{~cm}$., max. w $5.8 \mathrm{~cm}$., max. th $2.0 \mathrm{~cm}$.

Pink (7.5YR 7/4) on all of the unslipped surface. Hard paste; very sparsely porous, light brown (7.5YR $6 / 4$ ) fabric with fabric with some tiny lime and sand inclusions.

153- ( $\left.\mathrm{N}^{\circ} 80\right)$ : Handle fragment; Bath $\mathrm{B}$, room 3, found in 2007.

pl. $17 / 153$.

Max. h $7.6 \mathrm{~cm}$., max. w $4.4 \mathrm{~cm}$., max. th $1.6 \mathrm{~cm}$.

Carbon on exterior.

Red (2.5YR 5/6) slip on exterior; reddish brown (2.5YR 5/4), unslipped surface in interior. Hard paste; non-porous, fine, red $(2.5 \mathrm{YR} 4 / 6)$ fabric with some lime and rare sand inclusions.

154- ( $\left.\mathrm{N}^{\circ} 258\right)$ : Handle fragment; western tomb, found in 2007 .

pl. $18 / 154$.

Max. h 5.9 cm., max. w 8.4 cm., max. th $2.3 \mathrm{~cm}$.

Reddish brown (2.5YR 5/4) slip on exterior; light reddish brown (5YR 6/4), unslipped surface in interior. Soft paste; very sparsely porous, yellowish red (5YR 5/6) and greyish brown (10YR 5/2) mottled fabric with some mica as well as tiny lime and medium grit inclusions. 

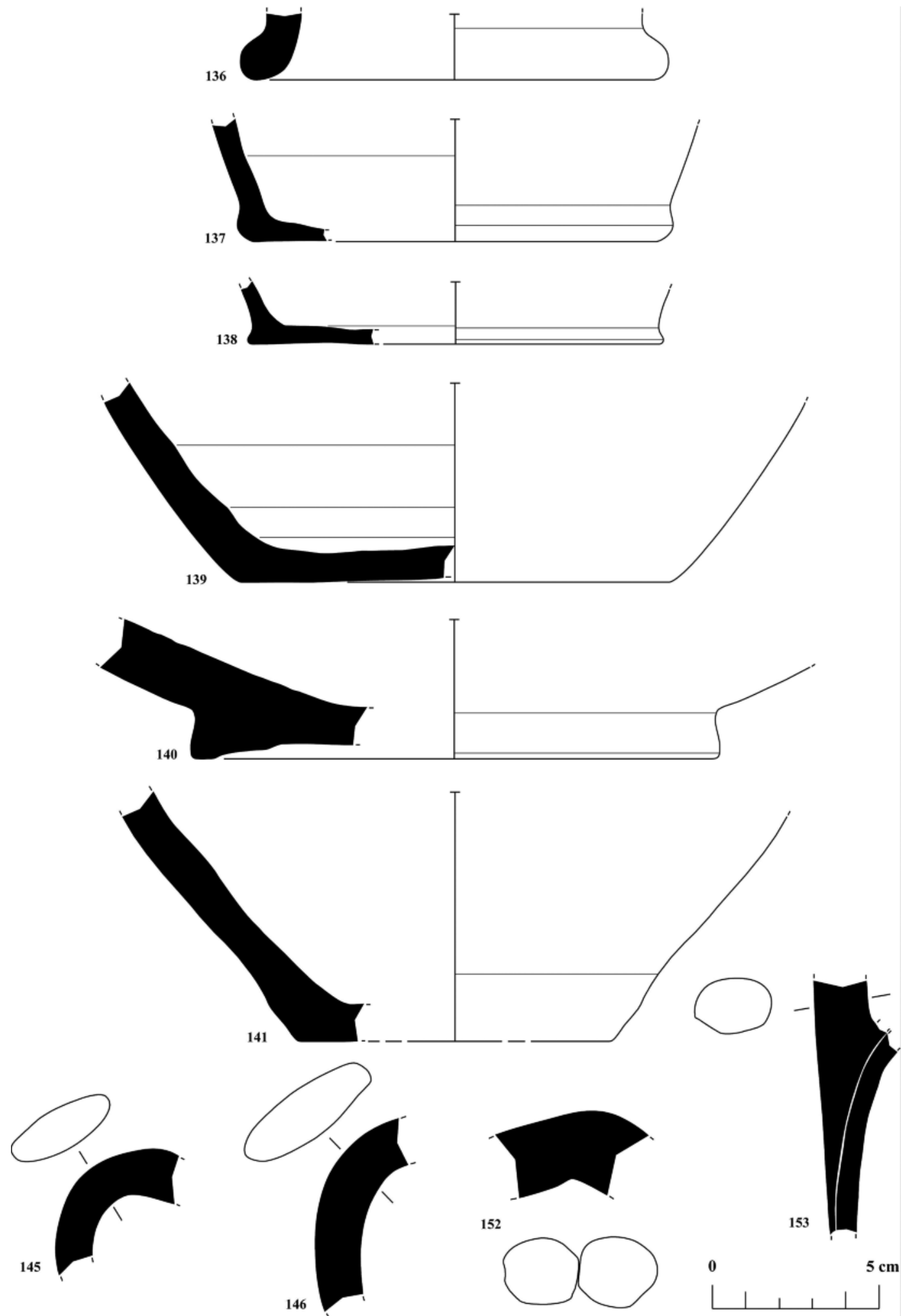

PI. 17 : $\mathbf{N}^{\text {os }}$ 136-153 : Miscellaneous coarse vessel fragments; ${ }^{\text {os }}$ 136-141: Base fragments of undetermined closed forms; and $\mathrm{n}^{\text {os }}$ 145-153: Handle fragments of undetermined closed forms. 
155- ( $\mathrm{N}^{\circ} 450$ ): Handle fragment; Kimistene, Acropolis, southern slope, just below the summit, towards Deresemail creek, found in 2005 .

pl. 23/155.

Max. $15.0 \mathrm{~cm}$., max. w $3.1 \mathrm{~cm}$., max. th $2.9 \mathrm{~cm}$.

Brown (7.5YR 5/3), unslipped surface on all of sherd. Hard paste; non-porous, fine, brown (7.5YR 5/3) fabric with rare sand and tiny lime inclusions.

156- ( No 453): Handle fragment; Kimistene, Acropolis, southern slope, just below the summit, towards Deresemail creek, found in 2005 .

pl. 23/156.

Max. $16.5 \mathrm{~cm}$., max. w $2.6 \mathrm{~cm}$., max. th $2.6 \mathrm{~cm}$.

Pink (5YR 7/4) ), unslipped surface both on exterior and interior. Hard paste; non-porous, fine, light reddish brown (5YR 6/6) fabric with some tiny lime and sand inclusions.

157- ( $\mathrm{N}^{\circ}$ 641): Handle fragment; Kimistene, Acropolis, western slope, found in 2005.

pl. 23/157.

Max. $13.7 \mathrm{~cm}$., max. w $4.7 \mathrm{~cm}$., max. th $2.1 \mathrm{~cm}$.

Light brown (7.5YR 6/4), unslipped surface both on exterior and interior. Hard paste; very sparsely porous, brown $(7.5 \mathrm{YR} 5 / 3)$ fabric with frequent tiny lime and sand inclusions.

158- (№ 449): Handle fragment; Kimistene, Acropolis, southern slope, just below the summit, towards Deresemail creek, found in 2005 .

pl. 18/158.

Max. h $4.4 \mathrm{~cm}$., max. w $4.6 \mathrm{~cm}$., max. th $2.1 \mathrm{~cm}$.

Light brown (7.5YR 6/4), unslipped surface both on exterior and interior. Hard paste; very sparsely porous, fine, reddish yellow (5YR 6/6) fabric with some tiny lime and sand inclusions.

159- (№ 1122): Handle fragment; Kimistene, Acropolis, found in 2005 .

pl. 23/159.

Max. $16.8 \mathrm{~cm}$., max. w $7.5 \mathrm{~cm}$., max. th $2.1 \mathrm{~cm}$.

Light reddish brown $(2.5 \mathrm{YR} 6 / 4)$ slip on exterior; light reddish brown (5YR 6/4), unslipped surface in interior. Hard paste; very sparsely porous, light reddish brown (5YR 6/4) fabric with frequent tiny lime inclusions.

160- ( $\left.\mathrm{N}^{\circ} 445\right)$ : Handle fragment; Kimistene, Acropolis, southern slope, just below the summit, towards Deresemail creek, found in 2005 .

pl. 18/160.

Max. $112.2 \mathrm{~cm}$., max. w $5.7 \mathrm{~cm}$., max. th $1.9 \mathrm{~cm}$.

Light brown (7.5YR 6/4) on all of the unslipped surface. Hard paste; very sparsely porous, light brown (7.5YR 6/4) fabric with some sand and tiny lime inclusions.
161- ( $\mathrm{N}^{\mathrm{o}}$ 1444): Handle fragment; Kimistene, Acropolis, southern slope, just below the summit, towards Deresemail creek, found in 2005.

pl. 23/161.

Max. $14.0 \mathrm{~cm}$., max. w $3.9 \mathrm{~cm}$., max. th $1.2 \mathrm{~cm}$.

Weak red (10R 5/4) slip on exterior; light reddish brown (2.5YR 6/4), unslipped surface in interior. Hard paste; non-porous, fine, red (2.5YR 5/6) fabric with frequent tiny lime inclusions.

162- ( $\left.\mathrm{N}^{\mathrm{0}} 1125\right)$ : Handle fragment; Kimistene, Acropolis, found in 2005 .

Max. $14.2 \mathrm{~cm}$., max. w $4.3 \mathrm{~cm}$., max. th $1.6 \mathrm{~cm}$.

Exterior is burnished.

Light reddish brown (5YR 6/4) slip on exterior; reddish brown (5YR 6/6), unslipped surface in interior. Hard paste; non-porous, fine, reddish brown (5YR 6/6) fabric with some tiny lime inclusions.

163- ( $\left.\mathrm{N}^{\circ} 817\right)$ : Handle fragment; Kimistene, summit of the Acropolis, western slope, found in 2005.

pl. 18/163.

Max. h $6.8 \mathrm{~cm}$. , max. w $5.9 \mathrm{~cm} .$, max. th $0.8 \mathrm{~cm}$.

Exterior is burnished.

Grey (2.5Y 5/1) slip on exterior; light grey (2.5Y $7 / 1$ ), unslipped surface in interior. Hard paste; very sparsely porous, fine, greyish brown $(2.5 \mathrm{Y} \mathrm{5/2})$ fabric with frequent tiny lime inclusions.

164- (No 874): Handle fragment; Kimistene, Acropolis, southern slope, underground cave, surface find, found in 2005.

pl. 24/164.

Max. $17.6 \mathrm{~cm}$., max. w $5.2 \mathrm{~cm}$., max. th $2.2 \mathrm{~cm}$.

Exterior is burnished.

Dark grey (2.5Y 4/1) slip on exterior; brown (10YR $5 / 3$ ), unslipped surface in interior. Hard paste; non-porous, fine, very dark grey $(2.5 \mathrm{Y} 3 / 1)$ fabric with frequent lime and large grit inclusions.

165- ( $\mathrm{N}^{\circ}$ 639): Handle fragment; Kimistene, Acropolis, western slope, found in 2005.

pl. $24 / 165$.

Max. $17.8 \mathrm{~cm}$., max. w $5.7 \mathrm{~cm}$., max. th $1.8 \mathrm{~cm}$.

Light brown (7.5YR 6/4), unslipped surface both on exterior and interior. Average hardness; non-porous, fine, light brown (7.5YR 6/4) fabric with some tiny lime and sand inclusions.

166- (№ 1286): Handle fragment; Kimistene, Acropolis, temple's terrace, found in 2005.

pl. 18/166.

Max. h $10.1 \mathrm{~cm}$. , max. w $8.9 \mathrm{~cm}$., max. th $1.5 \mathrm{~cm}$.

Red $(2.5 \mathrm{YR} 5 / 6)$ on all of the unslipped surface. Hard paste; non-porous, light brown (7.5YR 6/4) and reddish brown $(2.5 \mathrm{YR} 4 / 3)$ mottled fabric with some sand and tiny lime inclusions. 


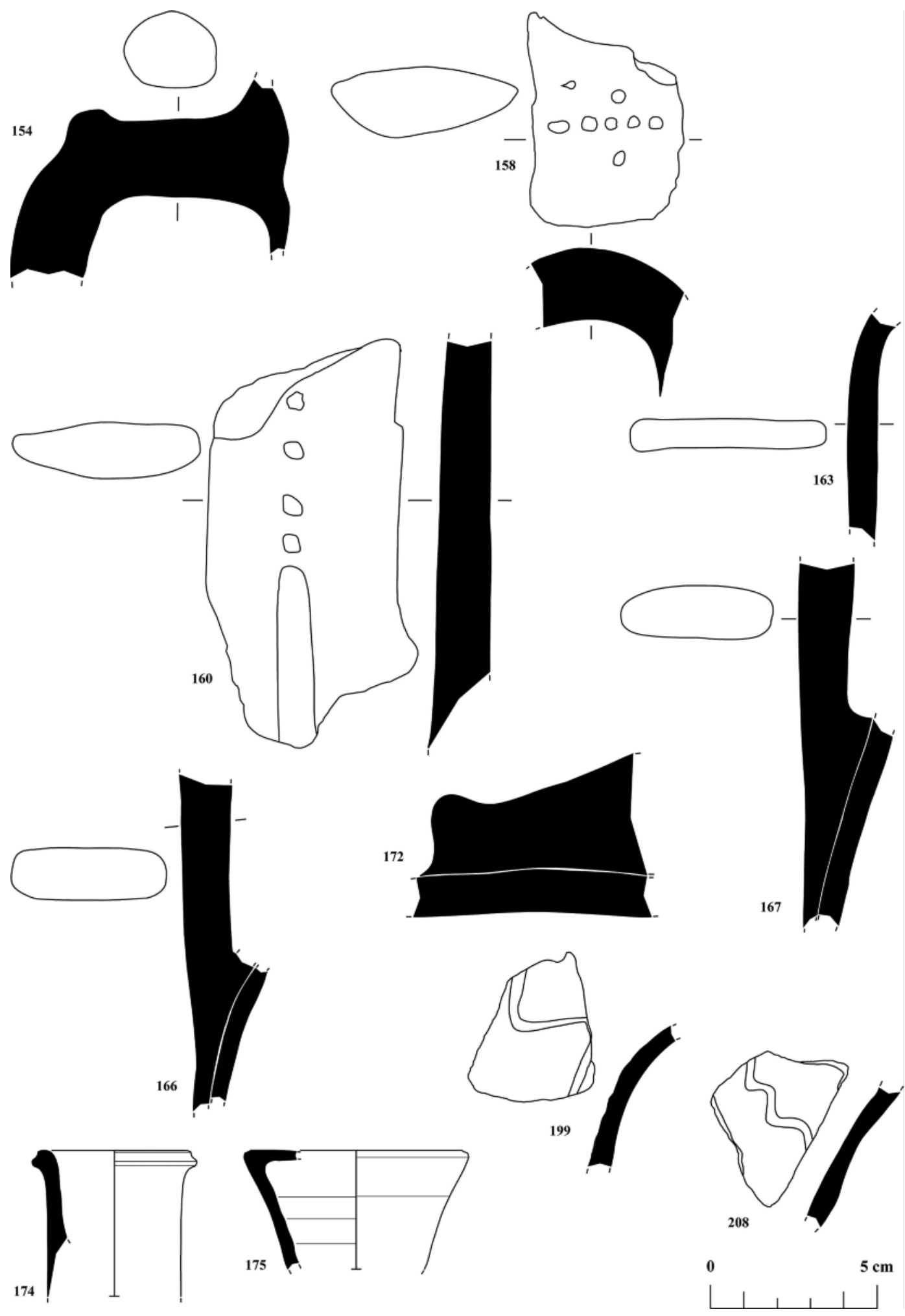

Pl. 18 : $\mathbf{N}^{\text {os }}$ 154-208 : Miscellaneous coarse vessel fragments; $n^{\text {os }}$ 154-172: Handle fragments of undetermined closed forms; and $n^{\text {os }}$ 174-208: Body fragments of undetermined closed forms. 
167- ( $\left.\mathrm{N}^{\circ} 1448\right)$ : Handle fragment; uncertain.

pl. 18/167.

Max. h 10.9 cm., max. w $6.7 \mathrm{~cm}$., max. th $1.7 \mathrm{~cm}$.

Grey (2.5Y 5/1) slip on exterior; light brownish grey (2.5Y 6/2), unslipped surface in interior. Hard paste; very sparsely porous, fine, grey $(2.5 \mathrm{Y} 5 / 1)$ fabric with rare mica and some large grit inclusions.

168- ( $\left.\mathrm{N}^{\circ} 1319\right)$ : Handle fragment; Kimistene, summit of the Acropolis, southern slope, found in 2005.

pl. 24/168.

Max. h $9.8 \mathrm{~cm}$., max. w $5.8 \mathrm{~cm}$., max. th $1.5 \mathrm{~cm}$.

Light brown (7.5YR 6/4) on all of the unslipped surface. Hard paste; very sparsely porous, light brown (7.5YR 6/4) some lime inclusions.

169- ( $\left.\mathrm{N}^{\circ} 635\right)$ : Handle fragment; Kimistene, Acropolis, found in 2005 .

pl. 24/169.

Max. h $9.0 \mathrm{~cm}$., max. w $6.5 \mathrm{~cm}$., max. th $1.9 \mathrm{~cm}$.

Red (2.5YR 5/6) slip both on exterior and interior. Hard paste; non-porous, fine, red (2.5YR 5/6) fabric with rare mica and some small grit inclusions.

170- (No 1254): Handle fragment; Kimistene, Necropolis I, surface find, found in 2005.

pl. 24/170.

Max. h $7.2 \mathrm{~cm}$., $\max$. w $4.1 \mathrm{~cm}$., $\max$. th $1.5 \mathrm{~cm}$.

Brown (7.5YR 5/3) on all of the unslipped surface. Hard paste; non-porous, brown (7.5YR 4/3) fabric with some sand and tiny lime inclusions.

171- ( $\left.\mathrm{N}^{\circ} 1253\right)$ : Handle fragment; Kimistene, Necropolis I, surface find, found in 2005.

pl. 24/171.

Max. h 3.9 cm., max. w $10.3 \mathrm{~cm}$., max. $16.3 \mathrm{~cm}$.

Reddish yellow (5YR 6/6), unslipped surface both on exterior and interior. Average hardness; non-porous, red $(2.5 \mathrm{YR} 5 / 8)$ fabric with frequent lime and sand as well as medium grit and mica inclusions.

172- ( $\left.\mathrm{N}^{\mathrm{o}} 1442\right)$ : Handle fragment; Kimistene, Acropolis, temple's terrace, found in 2005.

pl. 18/172.

Max. h $4.9 \mathrm{~cm}$., max. w $8.6 \mathrm{~cm}$., max. th $5.9 \mathrm{~cm}$.

Light brown (7.5YR 6/3) on all of the unslipped surface. Hard paste; non-porous, light brown (7.5YR 6/4) and light red (2.5YR 6/6) mottled fabric with some sand and tiny lime inclusions.

\section{Body Fragments of Undetermined Closed Forms} (pl.18, $\mathrm{n}^{\text {os }} 174-208$; pls. 25-29, $\left.\mathrm{n}^{\text {os }} 173-261\right)$

They represent almost exclusively closed tableware forms, most probably jugs. Some decoration on exterior surface is visible. 2005.
173- ( $\mathrm{N}^{\circ}$ 1048): Body fragment; Kepez, found in pl. 25/173.

Max. h $2.2 \mathrm{~cm}$., max. w $2.1 \mathrm{~cm}$., max. th $0.7 \mathrm{~cm}$.

Exterior is burnished.

Brown (7.5YR 5/3) slip on exterior; reddish brown (5YR 5/4), unslipped surface in interior. Average hardness; non-porous, reddish brown (5YR 5/4) and dark reddish grey $(2.5 Y R 3 / 1)$ mottled fabric with some tiny lime inclusions.

174- (No 849): Body fragment; Kimistene, Acropolis, surface find, found in 2005.

pl. 18/174.

Max. h $4.4 \mathrm{~cm}$., d of rim $4.2 \mathrm{~cm}$., max. w $2.7 \mathrm{~cm}$., $\max$. th $0.4 \mathrm{~cm}$.

Reddish yellow (5YR 6/6) slip both on exterior and interior rim; red (2.5YR 5/6) paint on exterior slip. Hard paste; non-porous, reddish yellow (5YR 6/6) and grey (5YR 5/1) mottled fabric some tiny lime and sand inclusions.

175- (No 140): Body fragment; uncertain.

pl. 18/175.

Max. h $3.6 \mathrm{~cm}$., d of rim $6.2 \mathrm{~cm}$., max. w $4.4 \mathrm{~cm}$., $\max$. th $0.4 \mathrm{~cm}$.

Red (10R 5/6) slip on exterior; reddish brown (2.5YR $5 / 4)$, unslipped surface in interior. Hard paste; very sparsely porous, red $(2.5 \mathrm{YR} 4 / 6)$ fabric with frequent tiny lime and sand inclusions.

176- (№ 1313): Body fragment; Kimistene, Acropolis, southern slope, found in 2005.

pl. 25/176.

Max. h 1.7 cm., max. w $1.8 \mathrm{~cm}$., max. th $0.6 \mathrm{~cm}$.

Reddish yellow (5YR 6/6) slip on exterior; reddish yellow (5YR 6/6), unslipped surface in interior. Average hardness, thin paste; non-porous, fine, reddish yellow (5YR 6/8) fabric with rare mica and frequent lime inclusions.

177- ( $\mathrm{N}^{\circ} 780$ ): Body fragment; Kimistene, Acropolis, temple's terrace, illegally excavated area under the temple's podium, surface find, found in 2005.

pl. 25/177.

Max. h 1.7 cm., max. w $2.7 \mathrm{~cm}$., max. th $0.5 \mathrm{~cm}$.

Dark grey (2.5Y 4/1), unslipped surface both on exterior and interior. Soft paste; non-porous, black $(2.5 \mathrm{Y}$ $2.5 / 1$ ) fabric with some medium grit and lime inclusions.

178- ( $\left.\mathrm{N}^{\mathrm{o}} 810\right)$ : Body fragment; Kimistene, summit of the Acropolis, western slope, found in 2005.

pl. 25/178.

Max. h 1.9 cm., max. w $2.5 \mathrm{~cm}$., max. th $0.7 \mathrm{~cm}$.

Exterior is burnished.

Very dark grey (10YR 3/1) slip on exterior; dark grey $(2.5 \mathrm{Y} 4 / 1)$, unslipped surface in interior. Average hardness; non-porous, dark grey $(2.5 \mathrm{Y} 4 / 1)$ and greyish brown (10YR 5/2) mottled fabric with rare mica inclusions. 
179- ( $\left.\mathrm{N}^{\circ} 781\right)$ : Body fragment; Kimistene, Acropolis, temple's terrace, illegally excavated area under the temple's podium, surface find, found in 2005.

pl. $25 / 179$.

Max. h $2.3 \mathrm{~cm}$., max. w $1.9 \mathrm{~cm}$., max. th $0.5 \mathrm{~cm}$.

Dark grey (2.5Y 4/1), unslipped surface both on exterior and interior. Soft paste; non-porous, black (2.5Y 2.5/1) fabric with frequent tiny lime and some quartz inclusions.

180- ( $\mathrm{N}^{\circ} 756$ ): Body fragment; Kimistene, Acropolis, temple's terrace, illegally excavated area under the temple's podium, surface find, found in 2005.

pl. 25/180.

Max. h $2.8 \mathrm{~cm}$., max. w $2.9 \mathrm{~cm}$., max. th $0.5 \mathrm{~cm}$.

Grey (10YR 5/1), unslipped surface on exterior; light brownish grey (10YR 6/2), unslipped surface in interior. Average hardness; non-porous, greyish brown (10YR $5 / 2$ ) fabric with frequent tiny lime and some quartz inclusions.

181- ( $\left.\mathrm{N}^{\circ} 752\right)$ : Body fragment; Kimistene, Acropolis, temple's terrace, illegally excavated area under the temple's podium, found in 2005 .

pl. 25/181.

Max. h $2.1 \mathrm{~cm}$., max. w $3.1 \mathrm{~cm}$., max. th $0.8 \mathrm{~cm}$.

Exterior is blackened.

Light brown (7.5YR 6/4), unslipped surface both on exterior and interior. Soft paste; non-porous, fine, light brown (7.5YR 6/4) fabric with some lime inclusions.

182- ( $\mathrm{N}^{\circ}$ 1346): Body fragment; Kimistene, cistern, eastern slope, found in 2005.

pl. 25/182.

Max. h $2.4 \mathrm{~cm}$., max. w $3.1 \mathrm{~cm}$., max. th $0.9 \mathrm{~cm}$.

Reddish brown (5YR 5/4), unslipped surface both on exterior and interior. Average hardness; very sparsely porous, very dark grey (7.5YR 3/1) fabric with frequent lime and large grit as well as rare quartz inclusions.

183- ( $\left.\mathrm{N}^{\circ} 1373\right)$ : Body fragment; Kepez, necropolis, found in 2005 .

pl. $25 / 183$.

Max. h 2.4 cm., max. w $2.2 \mathrm{~cm}$., max. th $0.7 \mathrm{~cm}$.

Red (2.5YR 5/6) slip on exterior; reddish brown (2.5YR 5/4), unslipped surface in interior. Soft paste; non-porous, fine, red (2.5YR 5/6) fabric with some lime as well as medium grit and rare mica inclusions.

184- ( $\mathrm{N}^{\mathrm{o}} 755$ ): Body fragment; Kimistene, Acropolis, temple's terrace, illegally excavated area under the temple's podium, surface find, found in 2005.

pl. 25/184.

Max. h $2.5 \mathrm{~cm}$., max. w $2.5 \mathrm{~cm}$., $\max$. th $0.5 \mathrm{~cm}$.

All of the surface is blackened.

Very pale brown (10YR 7/3), unslipped surface both on exterior and interior. Average hardness; very sparsely porous, black (10YR 2/1) fabric with some lime and sand inclusions.
185- ( $\mathrm{N}^{\circ} 765$ ): Body fragment; Kimistene, Acropolis, temple's terrace, illegally excavated area under the temple's podium, surface find, found in 2005.

pl. $25 / 185$.

Max. h $3.0 \mathrm{~cm}$., $\max$. w $2.8 \mathrm{~cm}$., $\max$. th $0.8 \mathrm{~cm}$

Dark grey (2.5Y 4/1), unslipped surface on exterior; brown (7.5YR 5/2), unslipped surface in interior. Soft paste; very sparsely porous, brown (7.5YR 4/2) fabric with frequent lime and small grit inclusions.

186- ( $\mathrm{N}^{\circ} 718$ ): Body fragment; Kimistene, Acropolis, temple's terrace, illegally excavated area under the temple's podium, surface find, found in 2005.

Max. h $2.4 \mathrm{~cm}$., max. w $3.2 \mathrm{~cm}$., $\max$. th $0.8 \mathrm{~cm}$. pl. 25/186.

Interior surface is blackened.

Grey (10YR 5/1) slip on exterior; grey (10YR 6/1), unslipped surface in interior. Hard paste; very sparsely porous, fine, grey (10YR 6/1) fabric with some lime inclusions.

187- ( $\left.\mathrm{N}^{\circ} 1295\right)$ : Body fragment; Kimistene, Acropolis, temple's terrace, illegally excavated area, found in 2005 . pl. $25 / 187$.

Max. h 2.7 cm., max. w $3.0 \mathrm{~cm}$., max. th $0.7 \mathrm{~cm}$.

Exterior is burnished which is also grooved.

Dark grey $(2.5 \mathrm{Y} 4 / 1)$ slip on exterior; dark grey (2.5Y 4/1), unslipped surface in interior. Average hardness; very sparsely porous, fine, black (2.5Y 2.5/1) fabric with some sand and mica inclusions.

188- ( $\mathrm{N}^{\circ} 733$ ): Body fragment; Kimistene, Acropolis, temple's terrace, illegally excavated area under the temple's podium, surface find, found in 2005 .

pl. $25 / 188$.

Max. h $3.0 \mathrm{~cm}$., max. w $2.9 \mathrm{~cm}$., $\max$. th $0.5 \mathrm{~cm}$

Exterior is burnished.

Very dark grey (Gley $13 / \mathrm{N}$ ) slip on exterior; grey (Gley $16 / N$ ), unslipped surface in interior. Average hardness; non-porous, fine, dark grey (Gley $14 / \mathrm{N}$ ) fabric with frequent tiny lime inclusions.

189- ( $\mathrm{N}^{\circ} 773$ ): Body fragment; Kimistene, Acropolis, temple's terrace, illegally excavated area under the temple's podium, surface find, found in 2005 .

pl. 25/189.

Max. h $3.1 \mathrm{~cm}$., max. w $3.7 \mathrm{~cm}$., max. th $0.5 \mathrm{~cm}$.

Very dark grey (5YR 3/1), unslipped surface on exterior; grey (Gley $15 / \mathrm{N}$ ), unslipped surface in interior. Average hardness; non-porous, very dark grey (10YR 3/1) fabric with frequent tiny lime and some quartz inclusions.

190- ( $\mathrm{N}^{\circ}$ 501): Body fragment; Kimistene, Acropolis, southern slope, just below the summit, towards Deresemail creek, found in 2005. 
pl. $25 / 190$.

Max. h $3.1 \mathrm{~cm}$., max. w $2.9 \mathrm{~cm}$., max. th $0.7 \mathrm{~cm}$.

Exterior is burnished. Interior surface is blackened.

Brown (7.5YR 5/4) slip on exterior; very dark grey (Gley $13 / \mathrm{N}$ ), unslipped surface in interior. Hard paste; non-porous, very dark grey (Gley $13 / \mathrm{N}$ ) fabric with some tiny lime and rare mica inclusions. 2005 .

191- ( $\mathrm{N}^{\circ}$ 993): Body fragment; Kepez, found in

pl. 25/191.

Max. h $3.4 \mathrm{~cm}$., max. w $2.5 \mathrm{~cm}$., max. th $0.8 \mathrm{~cm}$.

Light reddish brown (5YR 6/4) slip on exterior; brown (7.5YR 5/4), unslipped surface in interior. Soft paste; very sparsely porous, brown (7.5YR 5/4) and dark grey (7.5YR 4/1) mottled fabric with some lime and small grit inclusions.

192- (No 644): Body fragment; Kimistene, Acropolis, western slope, found in 2005.

pl. 25/192.

Max. h $3.0 \mathrm{~cm}$., max. w $3.1 \mathrm{~cm}$., max. th $0.7 \mathrm{~cm}$.

Light reddish brown (2.5YR 7/4), unslipped surface on exterior; pale red (2.5YR 6/2), unslipped surface in interior. Hard and thin paste; non-porous, pink (5YR 7/4) fabric with frequent tiny lime and sand inclusions.

193- ( $\mathrm{N}^{\circ} 738$ ): Body fragment; Kimistene, Acropolis, southern slope, just below the summit, towards Deresemail creek, found in 2005 .

pl. 25/193.

Max. h $3.0 \mathrm{~cm}$., max. w $3.5 \mathrm{~cm}$., $\max$. th $0.6 \mathrm{~cm}$.

Reddish brown (2.5YR 5/4) slip on exterior; reddish yellow (5YR 6/6), unslipped surface in interior. Hard and thin paste; non-porous, fine, reddish brown (5YR 5/4) fabric with some sand as well as rare mica and lime inclusions.

194- ( $N^{\circ}$ 657): Body fragment; Kimistene, cistern, eastern slope, found 2005.

pl. 25/194.

Max. h $3.0 \mathrm{~cm}$., max. w $4.1 \mathrm{~cm}$., $\max$. th $1.1 \mathrm{~cm}$.

Exterior is burnished. Shallow grooves on exterior.

Light reddish brown (5YR 6/4) slip on exterior; pinkish grey (7.5YR 6/2), unslipped surface in interior. Hard paste; non-porous, reddish yellow (5YR 6/6) fabric with some tiny lime inclusions.

195- ( $\left.\mathrm{N}^{\circ} 724\right)$ : Body fragment; Kimistene, Acropolis, temple's terrace, illegally excavated area under the temple's podium, surface find, found in 2005.

pl. 25/195.

Max. h $3.0 \mathrm{~cm}$., max. w $4.0 \mathrm{~cm}$., $\max$. th $0.7 \mathrm{~cm}$.

Very pale brown (10YR 8/2) slip on exterior; pink (7.5YR 7/4), unslipped surface in interior; Average hardness; non-porous, fine, pink (7.5YR 7/4) fabric with rare mica as well as sand and lime inclusions.
196- ( $\mathrm{N}^{\circ}$ 826): Body fragment; Kimistene, summit of the Acropolis, western slope, found in 2005.

pl. 25/196.

Max. h $2.7 \mathrm{~cm}$. , max. w $5.7 \mathrm{~cm}$., max. th $0.4 \mathrm{~cm}$.

Pink (5YR 7/4) slip on exterior; light reddish brown (5YR 6/4) slip on interior. Average hardness; non-porous, fine, red (2.5YR 5/6) fabric with some tiny lime inclusions.

197- (No 923): Body fragment; Kimistene, Acropolis, found in 2005 .

pl. $25 / 197$.

Max. h $3.1 \mathrm{~cm}$., max. w $4.7 \mathrm{~cm}$., max. th $0.6 \mathrm{~cm}$.

Reddish yellow (5YR 6/6), unslipped surface both on exterior and interior. Hard paste; non-porous, fine, reddish yellow (5YR 6/8) fabric with occasional tiny lime inclusions.

198- (№ 933): Body fragment; Kimistene, Acropolis, found in 2005 .

Max. h $3.3 \mathrm{~cm}$., max. w $4.1 \mathrm{~cm}$., $\max$. th $0.8 \mathrm{~cm}$.

Reddish yellow (5YR 7/6), unslipped surface on exterior; pink (5YR 7/4), unslipped surface in interior. Hard paste; very sparsely porous, fine, light red (2.5YR 6/8) fabric with some tiny lime inclusions.

199- ( $\left.\mathrm{N}^{\circ} 808\right)$ : Body fragment; Kimistene, summit of the Acropolis, western slope, found in 2005.

pl. 18/199.

Max. h $4.2 \mathrm{~cm}$., max. w $4.2 \mathrm{~cm}$., $\max$. th $0.6 \mathrm{~cm}$.

Wavy line decoration on exterior ${ }^{113}$.

Light brown (7.5YR 6/3), unslipped surface both on exterior and interior. Soft paste; porous, fine, reddish yellow (5YR 6/6) fabric with frequent tiny lime and sand inclusions.

200- ( $\left.\mathrm{N}^{0} 1203\right)$ : Body fragment; Kimistene, summit of the Acropolis, southern slope, found in 2005.

pl. 25/200.

Max. h $3.6 \mathrm{~cm}$., max. w $5.0 \mathrm{~cm}$., max. th $0.6 \mathrm{~cm}$.

Light red (2.5YR 6/6), unslipped surface both on exterior and interior. Hard paste; very sparsely porous, fine, light red (2.5YR 6/6) fabric with occasional tiny lime inclusions.

201- ( $\mathrm{N}^{\circ}$ 807): Body fragment; Kimistene, summit of the Acropolis, western slope, found in 2005.

Max. h $3.6 \mathrm{~cm}$., max. w $4.3 \mathrm{~cm}$., max. th $0.6 \mathrm{~cm}$. pl. 25/201.

Light red (2.5YR 6/8) slip on exterior; reddish brown (2.5YR 4/4) slip on interior. Hard paste; very sparsely porous, red (2.5YR 5/6) and dark grey (7.5YR 4/1) mottled fabric with frequent tiny lime inclusions. 
202- ( $\mathrm{N}^{\circ}$ 915): Body fragment; Kimistene, Acropolis, southeastern slope, on the way to the cistern, on a rocky slope, surface find, found in 2005.

pl. $25 / 202$.

Max. h $3.5 \mathrm{~cm}$., max. w $5.9 \mathrm{~cm}$., max. th $0.8 \mathrm{~cm}$.

Reddish yellow (5YR 6/6), unslipped surface both on exterior and interior. Hard paste; non-porous, fine, yellowish red (5YR 5/8) fabric with frequent tiny lime inclusions.

203- ( $\left.\mathrm{N}^{\circ} 774\right)$ : Body fragment; Kimistene, Acropolis, temple's terrace, illegally excavated area under the temple's podium, surface find, found in 2005.

pl. $25 / 203$.

Max. h $3.5 \mathrm{~cm}$., max. w $4.8 \mathrm{~cm}$., max. th $0.8 \mathrm{~cm}$.

Light reddish brown (5YR 6/4) slip on exterior; pink (5YR 7/4), unslipped surface in interior. Hard paste; very sparsely porous, fine, pink (5YR 7/4) occasional tiny lime inclusions. 2005 .

204- ( $\mathrm{N}^{\circ}$ 676): Body fragment; Kepez, found in pl. 25/204.

Max. h $3.5 \mathrm{~cm}$., max. w $2.7 \mathrm{~cm}$., max. th $1.1 \mathrm{~cm}$.

Yellowish red (5YR 5/6), unslipped surface on exterior; reddish brown (5YR 5/4), unslipped surface in interior. Average hardness; very sparsely porous, red (2.5YR 4/6) and dark grey (5YR 4/1) mottled fabric with frequent tiny lime inclusions.

205- (No 929): Body fragment; Kimistene, Acropolis, found in 2005 .

pl. $25 / 205$.

Max. h $3.6 \mathrm{~cm}$., max. w $4.0 \mathrm{~cm}$., max. th $0.9 \mathrm{~cm}$.

Exterior is burnished.

Very pale brown (10YR 8/3) slip on exterior; light red $(2.5 \mathrm{YR} 6 / 6)$, unslipped surface in interior. Average hardness, thin paste; non-porous, fine, light red (2.5YR 6/6) fabric with occasional tiny lime inclusions.

206- ( $\mathrm{N}^{\circ}$ 1334): Body fragment; Kimistene, cistern, eastern slope, found in 2005.

pl. $25 / 206$.

Max. h $3.3 \mathrm{~cm}$., max. w $4.7 \mathrm{~cm}$., max. th $1.0 \mathrm{~cm}$.

Greyish brown (10YR 5/2), unslipped surface both on exterior and interior. Hard paste; non-porous, very dark grey (10YR 3/1) fabric with occasional tiny lime inclusions.

207- ( $\mathrm{N}^{0} 825$ ): Body fragment; Kimistene, summit of the Acropolis, western slope, found in 2005.

pl. 26/207.

Max. h $3.6 \mathrm{~cm}$., max. w $5.5 \mathrm{~cm}$., max. th $0.6 \mathrm{~cm}$.

Reddish yellow (5YR 7/6), unslipped surface both on exterior and interior. Soft paste; non-porous, fine, reddish yellow (5YR 6/6) fabric with some tiny lime and medium grit inclusions.

208- ( $\mathrm{N}^{\circ}$ 818): Body fragment; Kimistene, summit of the Acropolis, western slope, found in 2005.

pl. 18/208.

Max. h $4.2 \mathrm{~cm}$. , max. w $4.3 \mathrm{~cm}$., max. th $0.7 \mathrm{~cm}$.

Incised wavy line decoration on exterior ${ }^{114}$.

Greyish brown (10YR 5/2), unslipped surface on exterior; dark greyish brown (10YR 4/2), unslipped surface in interior. Average hardness; non-porous, dark greyish brown (10YR 4/2) fabric with occasional tiny lime and sand inclusions.

209- ( $\mathrm{N}^{\circ}$ 339): Body fragment; Bath $\mathrm{B}$, room 1 , found in 2007.

pl. 26/209.

Max. h $3.9 \mathrm{~cm}$., $\max$. w $3.4 \mathrm{~cm}$., $\max$. th $0.4 \mathrm{~cm}$

Reddish brown (2.5YR 5/4) slip on exterior; reddish brown (5YR 5/4), unslipped surface in interior. Hard and thin paste; non-porous, reddish yellow (5YR 6/6) fabric with some tiny lime inclusions.

210- ( No 1501): Body fragment; Kimistene, Acropolis, temple's terrace, found in 2005.

pl. $26 / 210$.

Max. h 3.8 cm., max. w $4.2 \mathrm{~cm}$., max. th $0.8 \mathrm{~cm}$

Very pale brown (10YR 8/3), unslipped surface both on exterior and interior. Hard paste; non-porous, fine, very pale brown (10YR 7/4) fabric with frequent sand inclusions.

211- ( $\mathrm{N}^{\circ} 751$ ): Body fragment; Kimistene, Acropolis, temple's terrace, illegally excavated area under the temple's podium, found in 2005 .

pl. 26/211.

Max. h 4.0 cm., max. w $3.4 \mathrm{~cm}$., max. th $0.5 \mathrm{~cm}$.

Grey (10YR 6/1), unslipped surface both on exterior and interior. Hard paste; very sparsely porous, fine, greyish brown (10YR 5/2) fabric with occasional quartz inclusions.

212- ( $\mathrm{N}^{\circ}$ 677): Body fragment; Kimistene, cistern, eastern slope, found in 2005.

pl. 26/212.

Max. h $3.9 \mathrm{~cm}$. , max. w $4.2 \mathrm{~cm}$., max. th $0.7 \mathrm{~cm}$

Red (2.5YR 5/6), unslipped surface both on exterior and interior. Soft paste; very sparsely porous, red (2.5YR 4/6) fabric with frequent sand inclusions.

213- (No 917): Body fragment; Kimistene, Acropolis, southeastern slope, on the way to the cistern, on a rocky slope, surface find, found in 2005.

pl. $26 / 213$.

Max. h $3.9 \mathrm{~cm}$., max. w $4.5 \mathrm{~cm}$., max. th $0.7 \mathrm{~cm}$ 
Reddish yellow (7.5YR 7/6), unslipped surface on exterior; light red (2.5YR 6/6), unslipped surface in interior. Hard paste; non-porous, fine, reddish yellow (7.5YR 6/6) fabric with some sand and rare mica inclusions.

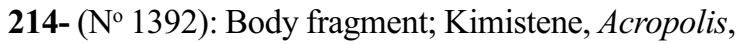
southern slope, just below the summit, towards Deresemail creek, found in 2005 .

pl. 26/214.

Max. h $4.0 \mathrm{~cm}$., max. w $4.3 \mathrm{~cm}$., $\max$. th $0.8 \mathrm{~cm}$.

Light brown (7.5YR 6/4), unslipped surface both on exterior and interior. Hard paste; non-porous, brown (7.5YR 5/3) fabric with some tiny lime inclusions. 2005 .

215- ( $\mathrm{N}^{\circ}$ 1361): Body fragment; Kepez, found in

pl. 26/215.

Max. h $4.3 \mathrm{~cm}$., max. w $4.3 \mathrm{~cm}$., max. th $0.8 \mathrm{~cm}$.

Pale brown (10YR 6/3), unslipped surface on exterior; brown (7.5YR 5/3), unslipped surface in interior. Soft paste; non-porous, brown (7.5YR 5/3) fabric with frequent tiny lime and some sand inclusions. 2005

216- ( $N^{\circ}$ 985): Body fragment; Kepez, found in

pl. 26/216.

Max. h 3.8 cm., max. w $4.0 \mathrm{~cm}$., max. th $1.4 \mathrm{~cm}$.

Dark grey (10YR 4/1), unslipped surface both on exterior and interior. Hard paste; non-porous, fine, very dark grey (10YR 3/1) fabric with frequent lime and large grit inclusions.

217- (No 793): Body fragment; Kimistene, Acropolis, temple's terrace, illegally excavated area under the temple's podium, surface find, found in 2005.

pl. $26 / 217$.

Max. h $4.0 \mathrm{~cm}$., max. w $5.0 \mathrm{~cm}$., max. th $1.2 \mathrm{~cm}$.

Stamped decoration on exterior.

Light reddish brown (2.5YR 6/4) slip on exterior; light red (2.5YR 6/6) surface on unslipped interior. Hard paste; very sparsely porous, fine, light red (2.5YR 6/6) fabric with frequent tiny lime and sand inclusions.

218- ( ${ }^{o}$ 1452): Body fragment; uncertain.

pl. 26/218.

Max. h 3.9 cm., max. w $4.0 \mathrm{~cm}$., max. th $1.1 \mathrm{~cm}$.

Light red (2.5YR 6/6), unslipped surface on exterior; light reddish brown (5YR 6/4), unslipped surface in interior. Hard paste; non-porous, fine, reddish yellow (5YR 6/6) fabric with occasional tiny lime inclusions.

219- ( $\mathrm{N}^{\circ}$ 827): Body fragment; Kimistene, summit of the Acropolis, western slope, found in 2005.

pl. 26/219.

Max. h $4.3 \mathrm{~cm}$., max. w $5.4 \mathrm{~cm}$., max. th $0.9 \mathrm{~cm}$.

Exterior is burnished.
Red (2.5YR 5/8) slip on exterior; light red (2.5YR $6 / 6)$, unslipped surface in interior. Hard paste; non-porous, fine, red (2.5YR 5/6) fabric with some sand and rare lime inclusions.

220- ( $\mathrm{N}^{\circ}$ 1147): Body fragment; Kimistene, Acropolis, temple's terrace, first slope on the north, found in 2005.

pl. 26/220.

Max. h $4.1 \mathrm{~cm}$., max. w $3.4 \mathrm{~cm}$., max. th $0.9 \mathrm{~cm}$.

Red (2.5YR 5/8) slip on exterior which is also burnished. Light red (2.5YR 6/6), unslipped surface in interior. Hard and thin paste; non-porous, fine, light red (2.5YR 6/6) fabric with some tiny lime and occasional grit inclusions.

221- (No 865): Body fragment; Kimistene, Acropolis, temple's terrace, illegally excavated area with bucranium altar, found in 2005 .

pl. 26/221.

Max. h $4.0 \mathrm{~cm}$., max. w $5.3 \mathrm{~cm}$., $\max$. th $1.3 \mathrm{~cm}$.

Exterior is burnished.

Reddish brown (5YR 5/4) slip on exterior; light grey (5YR 7/1), unslipped surface in interior. Hard paste; nonporous, bluish black (Gley 2 2.5/1) fabric with frequent tiny lime inclusions.

222- ( $\mathrm{N}^{\circ}$ 1291): Body fragment; Kimistene, Acropolis, temple's terrace, illegal excavation area, found in 2005.

pl. 26/222.

Max. h 4.4 cm., max. w $4.4 \mathrm{~cm}$., max. th $0.8 \mathrm{~cm}$.

Interior surface is blackened.

Grey (10YR 5/1), unslipped surface on exterior; dark grey (10YR 4/1), unslipped surface in interior. Soft paste; very sparsely porous, fine, very dark grey (10YR 3/1) fabric with some tiny lime inclusions.

223- ( $\mathrm{N}^{\circ}$ 811): Body fragment; Kimistene, summit of the Acropolis, western slope, found in 2005.

pl. 26/223.

Max. h 4.3 cm., max. w $3.6 \mathrm{~cm}$., max. th $1.2 \mathrm{~cm}$.

Dark grey (10YR 4/1), unslipped surface both on exterior and interior. Average hardness; sparsely porous, pale brown (10YR 6/3) some tiny lime and large grit inclusions.

224- ( $\mathrm{N}^{\circ} 741$ ): Body fragment; Kimistene, Acropolis, temple's terrace, illegally excavated area under the temple's podium, found in 2005 .

pl. 26/224.

Max. h $4.0 \mathrm{~cm}$., max. w $3.0 \mathrm{~cm}$., max. th $0.5 \mathrm{~cm}$.

Very dark grey (10YR 3/1), unslipped surface both on exterior and interior. Average hardness; non-porous, fine, grey (10YR 5/1) fabric with some sand inclusions.

225- ( $\mathrm{N}^{\circ} 750$ ): Body fragment; Kimistene, Acropolis, temple's terrace, illegally excavated area under the temple's podium, surface find, found in 2005 . 
pl. $26 / 225$.

Max. h $3.7 \mathrm{~cm}$., max. w $6.8 \mathrm{~cm}$., max. th $0.9 \mathrm{~cm}$.

Wheel marks on interior.

Dark grey (2.5Y 4/1), unslipped surface on exterior; grey $(2.5 \mathrm{Y} 5 / 1)$, unslipped surface in interior. Average hardness; non-porous, fine, dark grey (2.5Y 4/1) fabric with occasional lime inclusions.

226- ( $\mathrm{N}^{\circ}$ 496): Body fragment; Kimistene, Acropolis, southern slope, just below the summit, towards Deresemail creek, found in 2005 .

pl. 26/226.

Max. h $4.4 \mathrm{~cm}$., max. w $4.8 \mathrm{~cm}$., max. th $1.1 \mathrm{~cm}$.

Two horizontal bands on exterior.

Light brownish grey (10YR 6/2), unslipped surface both on exterior and interior. Hard paste; non-porous, reddish brown (5YR 4/4) and very dark grey (10YR 3/1) mottled fabric with frequent lime and medium grit inclusions.

227- (No 1458): Body fragment; Kimistene, Acropolis, found in 2005 .

pl. $26 / 227$.

Max. h $4.5 \mathrm{~cm}$., max. w $2.9 \mathrm{~cm}$., max. th $1.0 \mathrm{~cm}$.

Pale brown (10YR 6/3), unslipped surface on exterior; reddish yellow (5YR 6/6), unslipped surface in interior. Hard paste; non-porous, reddish yellow (5YR 6/6) and brown (7.5YR 5/3) mottled fabric with some large grit inclusions.

228- ( $\mathrm{N}^{\circ}$ 624): Body fragment; Kimistene, Acropolis, found in 2005 .

pl. 26/228.

Max. h $3.8 \mathrm{~cm}$., max. w $6.9 \mathrm{~cm}$., $\max$. th $1.2 \mathrm{~cm}$.

Exterior is burnished.

Reddish brown (5YR 5/4) slip on exterior; reddish yellow (5YR 6/6), unslipped surface in interior. Hard paste; non-porous, fine, reddish yellow (5YR 6/6) fabric with some sand and lime inclusions.

229- ( $\left.\mathrm{N}^{\circ} 1331\right)$ : Body fragment; Kepez, found 2005. pl. 26/229.

Max. h $4.5 \mathrm{~cm}$., max. w $5.2 \mathrm{~cm}$., max. th $0.6 \mathrm{~cm}$.

Light reddish brown (5YR 6/4) slip on exterior; yellowish red (5YR 5/6), unslipped surface in interior. Soft paste; non-porous, yellowish red (5YR 5/6) and grey (5YR 5/1) mottled fabric with frequent tiny lime and sand as well as occasional mica inclusions.

230- ( $\left.\mathrm{N}^{\circ} 747\right)$ : Body fragment; Kimistene, Acropolis, temple's terrace, illegally excavated area under the temple's podium, found in 2005 .

pl. 26/230.

Max. h $5.6 \mathrm{~cm}$., max. w $3.8 \mathrm{~cm}$., max. th $0.9 \mathrm{~cm}$.

Very dark grey (2.5Y 3/1) slip on exterior; very dark grey (2.5Y 3/1), unslipped surface in interior. Average hardness; very sparsely porous, fine, very dark grey $(2.5 \mathrm{Y}$ $3 / 1$ ) fabric with frequent tiny lime and occasional medium grit inclusions.
231- ( $\mathrm{N}^{\circ}$ 712): Body fragment; Kimistene, Acropolis, temple's eastern slope, surface find, found in 2005.

pl. 26/231.

Max. h 4.9 cm., max. w $4.4 \mathrm{~cm}$., max. th $0.8 \mathrm{~cm}$.

Wheel marks on interior.

Light brownish grey (10YR 6/2), unslipped surface both on exterior and interior. Hard paste; very sparsely porous, fine, greyish brown (10YR 5/2) fabric with some lime and grit inclusions.

232- ( $\left.\mathrm{N}^{\circ} 1401\right)$ : Body fragment; Hadrianoupolis, surface find, found in 2005 .

pl. $27 / 232$.

Max. h $4.9 \mathrm{~cm}$., max. w $4.7 \mathrm{~cm}$., $\max$. th $0.7 \mathrm{~cm}$.

Exterior is burnished.

Red (2.5YR 4/6), shiny slip on exterior; dark greyish brown (10YR 4/2), unslipped surface in interior. Hard paste; very sparsely porous, very dark grey (10YR 4/1) and red (2.5YR 5/6) mottled fabric with some lime and occasional grit inclusions.

233- ( $\mathrm{N}^{\circ}$ 1347): Body fragment; Kimistene, Acropolis, southern slope, just below the summit, towards Deresemail creek, found in 2005 .

pl. $27 / 233$.

Max. h 4.9 cm., max. w $4.7 \mathrm{~cm}$., max. th $0.8 \mathrm{~cm}$.

Exterior is burnished.

Pink (7.5YR 7/4) slip on exterior; light red (2.5YR $6 / 6)$, unslipped surface in interior. Hard paste; non-porous, fine, red (2.5YR 5/6) fabric with some tiny lime inclusions.

234- ( $\mathrm{N}^{\circ} 470$ ): Body fragment; Kimistene, Acropolis, southern slope, just below the summit, towards Deresemail creek, found in 2005 .

pl. 27/234.

Max. h $5.0 \mathrm{~cm}$., max. w $5.4 \mathrm{~cm}$., max. th $0.8 \mathrm{~cm}$.

Exterior is burnished. Wheel marks on interior.

Pink (7.5YR 8/3) slip on exterior; light reddish brown (5YR 6/4), unslipped surface in interior. Hard paste; nonporous, fine, reddish yellow (5YR 6/6) fabric with occasional tiny lime and sand inclusions.

235- ( No 512): Body fragment; Kimistene, Acropolis, southern slope, just below the summit, towards Deresemail creek, found in 2005 .

pl. 27/235.

Max. h $5.5 \mathrm{~cm}$., max. w $4.9 \mathrm{~cm}$., max. th $0.8 \mathrm{~cm}$.

Exterior is burnished.

Pink (7.5YR 8/3) slip on exterior; pink (7.5YR 7/4), unslipped surface in interior. Hard paste; non-porous, fine, reddish yellow (5YR 6/6) fabric with rare mica inclusions.

236- ( $\mathrm{N}^{\circ}$ 352): Body fragment; Bath $\mathrm{B}$, room 1, found in 2007.

pl. $27 / 236$.

Max. h 5.4 cm., max. w $6.2 \mathrm{~cm}$., max. th $0.7 \mathrm{~cm}$. 
Red (2.5YR 5/6) slip on exterior; reddish yellow (5YR 7/6), unslipped surface in interior. Hard paste; nonporous, fine, reddish yellow (5YR 6/6) fabric with occasional tiny lime inclusions.

237- ( $\mathrm{N}^{\circ}$ 210): Body fragment; Bath A, room 1, found in 2006.

pl. $27 / 237$.

Max. h 5.7 cm., max. w $4.8 \mathrm{~cm}$., max. th $1.1 \mathrm{~cm}$.

Light red (2.5YR 6/8), unslipped surface both on exterior and interior. Hard paste; sparsely porous, fine, light red (2.5YR 6/8) fabric with some sand inclusions.

238- (No 969): Body fragment; Kimistene, cistern, eastern slope, surface find, found in 2005.

pl. 27/238.

Max. h $6.0 \mathrm{~cm}$., max. w $6.8 \mathrm{~cm}$., $\max$. th $0.8 \mathrm{~cm}$.

Reddish yellow (5YR 6/6), unslipped surface both on exterior and interior. Hard paste; sparsely porous, fine, reddish yellow (5YR 6/8) fabric with frequent tiny lime and sand inclusions.

239- ( $\left.\mathrm{N}^{\circ} 455\right)$ : Body fragment; Kimistene, Acropolis, southern slope, just below the summit, towards Deresemail creek, found in 2005 .

pl. 27/239.

Max. h $6.5 \mathrm{~cm}$., max. w $6.4 \mathrm{~cm}$., max. th $0.9 \mathrm{~cm}$.

Reddish yellow (5YR 6/6), unslipped surface both on exterior and interior. Hard paste; non-porous, fine, reddish yellow (5YR 6/6) fabric with occasional tiny lime and sand inclusions.

240- ( $\mathrm{N}^{\circ}$ 1398): Body fragment; Kimistene, summit of the Acropolis, surface find, found in 2005.

pl. 27/240.

Max. h $6.7 \mathrm{~cm}$., max. w $6.6 \mathrm{~cm}$., $\max$. th $1.2 \mathrm{~cm}$.

Light red (2.5YR 6/8), unslipped surface on exterior; reddish yellow (5YR 6/6), unslipped surface in interior. Hard paste; non-porous, fine, reddish yellow (5YR 6/6) fabric with some tiny lime and sand inclusions.

241- (No 879): Body fragment; Kimistene, Acropolis, southern slope, underground cave, surface find, found in 2005 .

pl. 27/241.

Max. h $5.0 \mathrm{~cm}$., max. w $7.7 \mathrm{~cm}$., max. th $1.3 \mathrm{~cm}$.

Reddish yellow (5YR 6/6), unslipped surface both on exterior and interior. Hard paste; non-porous, fine, reddish yellow (5YR 6/6) fabric with occasional tiny lime inclusions.

242- ( $\left.\mathrm{N}^{0} 1320\right)$ : Body fragment; Kimistene, summit of the Acropolis, southern slope, found in 2005.

pl. 27/242.

Max. h $5.0 \mathrm{~cm}$., max. w $6.2 \mathrm{~cm}$., $\max$. th $0.7 \mathrm{~cm}$.

Light brown (7.5YR 6/3), unslipped surface on exterior; light brown (7.5YR 6/4), unslipped surface on exterior. Average hardness; non-porous, fine, brown (7.5YR 6/3) fabric with some tiny lime and sand inclusions.
243- ( $\mathrm{N}^{\mathrm{o}}$ 1376): Body fragment; Kepez, necropolis, found in 2005 .

pl. $27 / 243$.

Max. h $4.7 \mathrm{~cm}$., max. w $7.6 \mathrm{~cm}$., max. th $0.7 \mathrm{~cm}$.

Light brownish grey (10YR 6/2) slip on exterior; very pale brown (10YR 7/4), unslipped surface in interior. Hard paste; non-porous, fine, pale brown (10YR 6/3) fabric with some tiny lime and sand inclusions.

244- ( $\mathrm{N}^{\circ}$ 1355): Body fragment; Kimistene, cistern, eastern slope, found in 2005.

pl. $27 / 244$.

Max. h $4.8 \mathrm{~cm}$., max. w $5.3 \mathrm{~cm}$., max. th $1.3 \mathrm{~cm}$.

Reddish yellow (5YR 6/6), unslipped surface both on exterior and interior. Hard paste; non-porous, fine, reddish brown (5YR 5/4) fabric with infrequent tiny lime and rare quartz inclusions.

245- (No 875): Body fragment; Kimistene, Acropolis, southern slope, underground cave, surface find, found in 2005 .

pl. $27 / 245$.

Max. h $6.7 \mathrm{~cm}$., max. w $6.3 \mathrm{~cm}$., max. th $0.8 \mathrm{~cm}$.

Exterior is burnished.

Brown (10YR 5/3) slip on exterior; very pale brown (10YR 7/4), unslipped surface in interior. Hard paste; non-porous, fine, light yellowish brown (10YR 6/4) fabric with some sand and rare mica inclusions.

246- ( $\mathrm{N}^{\circ}$ 1248): Body fragment; Kimistene, western slope of the temenos; found in 2005.

pl. 27/246.

Max. h 4.9 cm., max. w $6.0 \mathrm{~cm}$., max. th $0.9 \mathrm{~cm}$.

Exterior is burnished.

Dark grey $(2.5 \mathrm{Y} 4 / 1)$ slip on exterior; grey $(2.5 \mathrm{Y}$ $5 / 1)$, unslipped surface in interior. Hard paste; non-porous, fine, dark grey $(2.5 \mathrm{Y} 4 / 1)$ fabric with frequent mica and sand inclusions.

247- (No 701): Body fragment; Kimistene, Acropolis, temple's eastern slope, surface find, found in 2005.

pl. $27 / 247$.

Max. h $6.8 \mathrm{~cm}$., max. w $5.5 \mathrm{~cm}$., max. th $0.8 \mathrm{~cm}$.

Light red (2.5YR 6/6), unslipped surface both on exterior and interior. Hard paste; non-porous, fine, red (2.5YR 5/6) fabric with occasional tiny lime and quartz inclusions.

248- (No 869): Body fragment; Kimistene, Acropolis, southern slope, underground cave, surface find, found in 2005 .

pl. 28/248.

Max. h $7.2 \mathrm{~cm}$., max. w $6.5 \mathrm{~cm}$., max. th $0.7 \mathrm{~cm}$.

Exterior is burnished.

Pink (7.5YR 7/4) slip on exterior; light red (2.5YR 6/6), unslipped surface in interior. Average hardness; very sparsely porous, fine, light red (2.5YR 5/6) fabric with frequent lime as well as grit and mica inclusions. 
249- ( $\left.\mathrm{N}^{\mathrm{o}} 702\right)$ : Body fragment; Kimistene, Acropolis, temple's eastern slope, surface find, found in 2005.

pl. 28/249.

Max. h 9.8 cm., max. w $7.0 \mathrm{~cm}$., max. th $0.8 \mathrm{~cm}$.

Yellowish red (5YR 5/6) thin slip on exterior; yellowish red $(5 \mathrm{YR} 5 / 6)$, unslipped surface in interior. Exterior is burnished. Hard and thin paste; very sparsely porous, red (2.5YR 4/8) and yellowish red (5YR 5/6) mottled fabric with frequent lime inclusions.

250- (№ 1298): Body fragment; Kimistene, Acropolis, temple's terrace, illegal excavation area, found in 2005.

pl. $28 / 250$.

Max. h $7.0 \mathrm{~cm}$., max. w $8.1 \mathrm{~cm}$., $\max$. th $0.7 \mathrm{~cm}$.

Exterior is burnished.

Light red (2.5YR 6/6) slip on exterior; light red (2.5YR 6/6), unslipped surface in interior. Hard paste; non-porous, fine, red (2.5YR 5/6) fabric with some tiny lime inclusions.

251- ( $\left.\mathrm{N}^{\circ} 469\right)$ : Body fragment; Kimistene, Acropolis, southern slope, just below the summit, towards Deresemail creek, found in 2005 .

pl. $28 / 251$.

Max. h $8.1 \mathrm{~cm}$., max. w $8.8 \mathrm{~cm}$., $\max$. th $1.3 \mathrm{~cm}$.

Exterior is burnished.

Very pale brown (10YR 8/2) slip on exterior; pinkish grey (7.5YR 7/2), unslipped surface in interior. Hard paste; non-porous, fine, light brown (7.5YR 6/4) fabric with frequent tiny lime and some grit inclusions.

252- ( $\left.\mathrm{N}^{\circ} 467\right)$ : Body fragment; Kimistene, Acropolis, southern slope, just below the summit, towards Deresemail creek, found in 2005 .

pl. $28 / 252$.

Max. h $7.6 \mathrm{~cm}$., max. w $8.0 \mathrm{~cm}$., $\max$. th $0.8 \mathrm{~cm}$.

Interior surface is blackened.

Dark grey (2.5Y 4/1), unslipped surface both on exterior and upper interior. Hard paste; non-porous, fine, brown (10YR 4/3) fabric with occasional medium grit inclusions.

253- ( No 1375): Body fragment; Kepez, necropolis, found in 2005 .

pl. 28/253.

Max. h 8.1 cm., max. w $7.2 \mathrm{~cm}$., max. th $0.8 \mathrm{~cm}$.

Dark grey (10YR 4/1), unslipped surface on exterior; brown (10YR 5/3), unslipped surface in interior. Soft paste; porous, fine, brown (10YR 5/3) occasional tiny lime and sand inclusions.

254- ( $\mathrm{N}^{\circ}$ 446): Body fragment; Kimistene, Acropolis, southern slope, just below the summit, towards Deresemail creek, found in 2005.

pl. 28/254.

Max. h 9.7 cm., max. w $5.6 \mathrm{~cm}$., max. th $1.1 \mathrm{~cm}$.

Red (2.5YR 5/6) slip on exterior; light red (2.5YR 6/6), unslipped surface in interior. Average hardness; non-porous, fine, red (2.5YR 5/6) fabric with occasional tiny lime inclusions.
255- (No 882): Body fragment; Kimistene, Acropolis, southern slope, underground cave, surface find, found in 2005 .

pl. $28 / 255$.

Max. h $8.0 \mathrm{~cm}$., max. w $6.9 \mathrm{~cm}$., $\max$. th $1.8 \mathrm{~cm}$.

Reddish brown (2.5YR 5/4), unslipped surface on exterior; brown (7.5YR 5/4), unslipped surface in interior. Hard paste; porous, reddish brown (2.5YR 4/3) fabric with large lime and grit inclusions.

256- ( $\mathrm{N}^{\circ}$ 1246): Body fragment; Kimistene, western slope of the temenos; found in 2005.

pl. $28 / 256$.

Max. h $6.0 \mathrm{~cm}$., max. w $7.0 \mathrm{~cm}$., max. th $1.2 \mathrm{~cm}$

Trumb impressed strips and combed bands on exterior. It is also decorated with a horizontal band of finger impressions as a "pinched decoration", which occurs on jugs from the Medieval to Post-Medieval periods.

Reddish yellow (5YR 7/6), unslipped surface both on exterior and interior. Hard paste; non-porous, reddish yellow (5YR 6/6) and grey (5YR 5/1) mottled fabric with some mica as well as frequent lime and medium grit inclusions.

257- (No 964): Body fragment; Kimistene, cistern, eastern slope, surface find, found in 2005.

pl. $29 / 257$.

Max. h 6.7 cm., max. w $10.3 \mathrm{~cm}$., max. th $1.4 \mathrm{~cm}$.

Light brown (7.5YR 6/4), unslipped surface both on exterior and interior. Hard paste; sparsely porous, fine, brown (7.5YR 5/4) fabric with occasional sand and tiny lime inclusions.

258- ( $\left.\mathrm{N}^{\circ} 182\right)$ : Body fragment; surface find from the Village Boncuklar, found in 2005.

pl. $29 / 258$.

Max. h $8.2 \mathrm{~cm}$. , max. w $9.5 \mathrm{~cm}$., max. th $0.6 \mathrm{~cm}$

Grey (10YR 5/1) slip on exterior; light brownish grey (10YR 6/2), unslipped surface in interior. Hard paste; very sparsely porous, fine, grey (10YR 5/1) fabric with some sand and rare tiny lime inclusions.

259- ( $\left.\mathrm{N}^{\circ} 1305\right)$ : Body fragment; Kimistene, Acropolis, found in 2005 .

pl. 29/259.

Max. h 8.5 cm., max. w 10.7 cm., max. th $1.1 \mathrm{~cm}$.

Exterior is burnished.

Light red (2.5YR 6/6) slip on exterior; light brown (10YR 6/3), unslipped surface in interior. Hard paste; very sparsely porous, fine, light brown (10YR 6/3) fabric with some tiny lime inclusions.

260- ( $\mathrm{N}^{\circ}$ 987): Body fragment; Kepez, found in 2005 .

pl. 29/260.

Max. h $3.8 \mathrm{~cm}$., max. w $9.2 \mathrm{~cm}$., max. th $1.0 \mathrm{~cm}$., $\max .110 .3 \mathrm{~cm}$. 
All of the surface is blackened.

Red (2.5YR 5/6) slip on exterior; light reddish brown (5YR 6/4), unslipped surface in interior. Soft and thin paste; sparsely porous, fine, light red (5YR 6/6) fabric with frequent medium grit and mica inclusions.

261- ( $\mathrm{N}^{\circ}$ 820): Body fragment; Kimistene, summit of the Acropolis, western slope, found in 2005.

pl. 29/261.

Max. h $8.2 \mathrm{~cm}$., max. w $9.2 \mathrm{~cm}$., max. th $1.8 \mathrm{~cm}$, $\max .110 .3 \mathrm{~cm}$.

Exterior is burnished.

Greyish brown (10YR 5/2) slip on exterior; light grey $(2.5 \mathrm{Y} 7 / 1)$, unslipped surface in interior. Average hardness; non-porous, fine, dark grey $(2.5 \mathrm{Y} 4 / 1)$ fabric with frequent tiny lime inclusions.

\section{Architectural Ceramics}

(pls. 19-21, nos 262-279; pls. 30-31, nos 266-279)

These materials included roof tiles, bricks, pipes and other architectural terracottas that constitute some of the most common finds at numerous Middle Byzantine sites. Most of them should be local production with various fabrics ${ }^{115}$. Most of them are originated from Kimistene and could had been reused in walls, floors and hearth constructions.

\section{Pipe Fragments}

$$
\text { (pls. 19-20, } \mathrm{n}^{\text {os }} 262-267 \text {; pl. 30, } \mathrm{n}^{\text {o }} 266 \text { ) }
$$

Both in Kimistene and Hadrianoupolis Middle Byzantine terracotta wheel-made water or drainage pipe fragments ${ }^{116}$ were found which were maintaining connections to both of the settlements' water supply that should be studied in detail. Several size ranges were found, by far the most common one is the medium size, i.e. the one with a diameter of $13.0-10.0 \mathrm{~cm}$.

262- ( $\mathrm{N}^{\circ}$ 618): Rim fragment; Kimistene, Acropolis, found in 2005 .

pl. $19 / 262$.

Max. h $8.3 \mathrm{~cm}$., d of rim $9.4 \mathrm{~cm}$., max. w $8.9 \mathrm{~cm}$., $\max$. th $1.3 \mathrm{~cm}$.

Light reddish brown (5YR 6/4) slip both on exterior and interior. Hard paste; non-porous, fine, yellowish red (5YR 5/6) fabric with frequent tiny lime as well as some rare small grit and quartz inclusions.

263- (No 1252): Rim fragment; Kimistene, Necropolis $\mathrm{I}$, found in 2005 .

pl. 19/263.

Max. h $10.5 \mathrm{~cm}$., d of rim $13.4 \mathrm{~cm}$., max. w $7.3 \mathrm{~cm}$., $\max$. th $1.8 \mathrm{~cm}$.
Reddish yellow (5YR 6/6), unslipped surface both on exterior and interior. Hard paste; non-porous, fine, yellowish red (5YR 5/6) fabric with frequent tiny lime and some small grit inclusions.

264- ( ${ }^{\circ}$ 1447): Rim fragment; uncertain.

pl. 19/264.

Max. h $8.6 \mathrm{~cm}$., d of rim $18.0 \mathrm{~cm}$., max. w $7.5 \mathrm{~cm}$., $\max$. th $1.4 \mathrm{~cm}$.

Light red (2.5YR 6/6), unslipped surface both on exterior and interior. Hard paste; non-porous, fine, light red (2.5YR 6/8) fabric with some tiny lime and small grit inclusions.

A similar example was found in Sagalassus ${ }^{117}$.

265- ( $\left.\mathrm{N}^{\circ} 395\right)$ : Rim fragment; Kimistene, Acropolis, northwestern slope of the temple, found in 2005.

pl. 19/265.

Max. h 7.9 cm., d of rim $22.0 \mathrm{~cm}$., max. w $10.0 \mathrm{~cm}$., $\max$. th $2.0 \mathrm{~cm}$.

Red (2.5YR 5/8), unslipped surface both on exterior and interior. Hard paste; non-porous, fine, red (2.5YR $5 / 8$ ) fabric with some tiny lime as well as occasional sand and medium grit inclusions.

266- (Nos 1544a-b): Rim fragment; Kimistene, Acropolis, slope of the temple, illegally excavated area under the podium, found in 2005 .

pl. $30 / 266$.

Two fragments.

Max. h $14.2 \mathrm{~cm}$., max. w $10.4 \mathrm{~cm}$., $\max$. th $2.0 \mathrm{~cm}$.,

Light red (2.5YR 6/6), unslipped surface both on exterior and interior. Hard paste; sparsely porous, reddish brown (2.5YR 5/4) and light red (2.5YR 6/6) mottled fabric with some sand and lime inclusions.

267- ( $\mathrm{N}^{\circ} 633$ ): Body fragment; Kimistene, Acropolis, found in 2005.

pl. $20 / 267$.

Max. h $9.5 \mathrm{~cm}$. , max. w $7.3 \mathrm{~cm}$. , max. th $1.0 \mathrm{~cm}$

Reddish brown (2.5YR 5/4) slip on exterior; reddish yellow (5YR 6/6), unslipped surface in interior. Hard paste; non-porous, yellowish red (5YR 5/6) fabric with some tiny lime inclusions.

\section{A Brick Fragment (pl. 21, nº 268)}

Its upper part is broken.

268- (No 1534): Kimistene, Acropolis, found in 2005. pl. 21/268.

Max. w $18.3 \mathrm{~cm}$., max. $119.8 \mathrm{~cm}$., max. th $3.4 \mathrm{~cm}$; frame: $2.7 \times 3.3 \mathrm{~cm}$.

115) J. Witte assumes that in Amorium there were five or more brick fabrics and several clay sources for the architectural ceramics: Witte 2012: 303.

116) Similar pipe fragments from Sagalassus: Degeest 2000: 141, 255, fig. 136, type 2K100.

117) Degeest 2000: 141 and 255, fig. 137. 
<smiles>II</smiles> 
Light red (2.5YR 6/6), unslipped surface both on exterior and interior. Hard paste; porous, fine, reddish brown (2.5YR 5/4) fabric with frequent lime and large grit inclusions.

Tile Fragments

(pls. 20-21, nos 269-277; pls. 30-31, nos 271-279)

All of the Middle Byzantine tile fragments were found in Kimistene, and they should had covered the top of the primitive observation structure at the summit of the Acropolis. The Middle Byzantine tiles from southwestern Paphlagonia have basically moulded relief designs, often with two parallel lines which diverge and taper at one end $^{118}$. Some fragments are heavy, thick and flat with a flanged profile. Since the architecture stops in Hadrianoupolis during the Middle Byzantine period, there is no later tile finds from Eskipazar. Many brick and tile fragments show designs made in the wet clay by finger or tool tips; the most common decoration is a set of two or three straight lines drawn parallel and next to two opposing edges on the top surface. Similarly to Amorium ${ }^{119}$ on $\mathrm{n}^{\circ} 275$ on pl. 30 there is an impressed dog paw on the exterior.

269- (No 396): Tile fragment; Kimistene, Acropolis, northwestern slope of the temple, found in 2005.

pl. 20/269.

Max. h 3.1 cm., max. w $5.0 \mathrm{~cm}$., max. $15.0 \mathrm{~cm}$. , max. th $1.5 \mathrm{~cm}$.

Reddish yellow (5YR 7/6), unslipped surface both on exterior and interior. Hard paste; very sparsely porous, fine, reddish yellow (5YR 7/6) fabric with frequent medium grit as well as medium grog and tiny lime inclusions.

270- ( $\mathrm{N}^{\circ}$ 614): Tile fragment; Kimistene, Acropolis, northwestern slope of the temple, found in 2005.

pl. 20/270.

Max. h 3.8 cm., max. w $6.4 \mathrm{~cm}$., $\max .110 .2 \mathrm{~cm}$., $\max$. th $2.0 \mathrm{~cm}$.

Pale brown (10YR 6/3), unslipped surface on exterior; dark reddish grey (5YR 4/2), unslipped surface in interior. Hard paste; non-porous, very dark grey (Gley $13 / \mathrm{N}$ ) fabric with some tiny lime inclusions.

271- ( $\mathrm{N}^{\circ}$ 1404): Tile fragment; Kimistene, Acropolis, northwestern slope of the temple, found in 2005.

pl. 30/271.

Max. h $4.5 \mathrm{~cm}$., max. w $11.5 \mathrm{~cm}$., max. $110.5 \mathrm{~cm}$., max. th $2.1 \mathrm{~cm}$.

Reddish yellow (5YR 6/6), unslipped surface both on exterior and interior. Soft paste; non-porous, fine, reddish yellow (5YR 6/6) fabric with some tiny lime and mica inclusions. 2005 .

272- ( $\mathrm{N}^{\circ}$ 1537): Tile fragment; Kimistene, found in pl. 21/272.

Max. w $18.1 \mathrm{~cm}$., max. $116.4 \mathrm{~cm}$., max. th $4.0 \mathrm{~cm}$.

Light red (2.5YR 6/6), unslipped surface both on exterior and interior. Hard paste; sparsely porous, fine, light red (2.5YR 6/6) fabric with frequent lime as well as sand and small grit inclusions.

273- ( $\left.\mathrm{N}^{\circ} 1543\right)$ : Tile fragment; Kimistene, found in 2005.

pl. $30 / 273$.

Max. w 4.7 cm., max. $14.0 \mathrm{~cm}$.

Red (2.5YR 5/6), unslipped surface both on exterior and interior. Hard paste; non-porous, fine, red (2.5YR 5/6) fabric with some sand and lime inclusions.

274- ( $\mathrm{N}^{\circ}$ 1542): Tile fragment; Kimistene, found in 2005.

Max. w $5.5 \mathrm{~cm}$., max. $14.2 \mathrm{~cm}$.

pl. 30/274.

Red (2.5YR 5/6), unslipped surface both on exterior and interior. Hard paste; non-porous, fine, reddish brown (2.5YR 4/3) fabric with some sand and small grit inclusions. 2005 .

275- ( $\mathrm{N}^{\circ}$ 1539): Tile fragment; Kimistene, found in

Max. w $12.4 \mathrm{~cm} .$, max. $111.4 \mathrm{~cm}$.

pl. $30 / 275$.

Impression of a dog paw on exterior.

Light reddish brown (2.5YR 6/4), unslipped surface both on exterior and interior. Hard paste; porous, fine, light red (2.5YR 6/6) fabric with frequent lime as well as sand and small grit inclusions. 2005

276- ( $\left.\mathrm{N}^{\circ} 1535\right)$ : Tile fragment; Kimistene, found in pl. $21 / 276$.

Max. w 13.7 cm., max. $112.7 \mathrm{~cm}$., max. th $2.2 \mathrm{~cm}$.

Decorated with moulded relief lines.

Reddish yellow (5YR 6/6), unslipped surface both on exterior and interior. Hard paste; porous, fine, reddish yellow (5YR 6/6) fabric with some tiny lime and sand inclusions. 2005.

277- ( $\mathrm{N}^{\circ}$ 1536): Tile fragment; Kimistene, found in pl. 21/277.

Max. w $20.5 \mathrm{~cm}$., max. $121.1 \mathrm{~cm}$., max. th $2.6 \mathrm{~cm}$.

118) Anderson 2011: 93. Comparable examples from Chersonesus in the Crimea are dated to the $9^{\text {th }}-10^{\text {th }}$ cent. A.D. and later: Romančuk 2005: 125 .

119) Witte 2012: 338, $n^{\text {os }}$ 352-353: For the impressed examples with animal paws at Amorium J. Witte assumes that either the animal strayed into the area, or these architectural ceramics were produced in a more open and rural setting. 

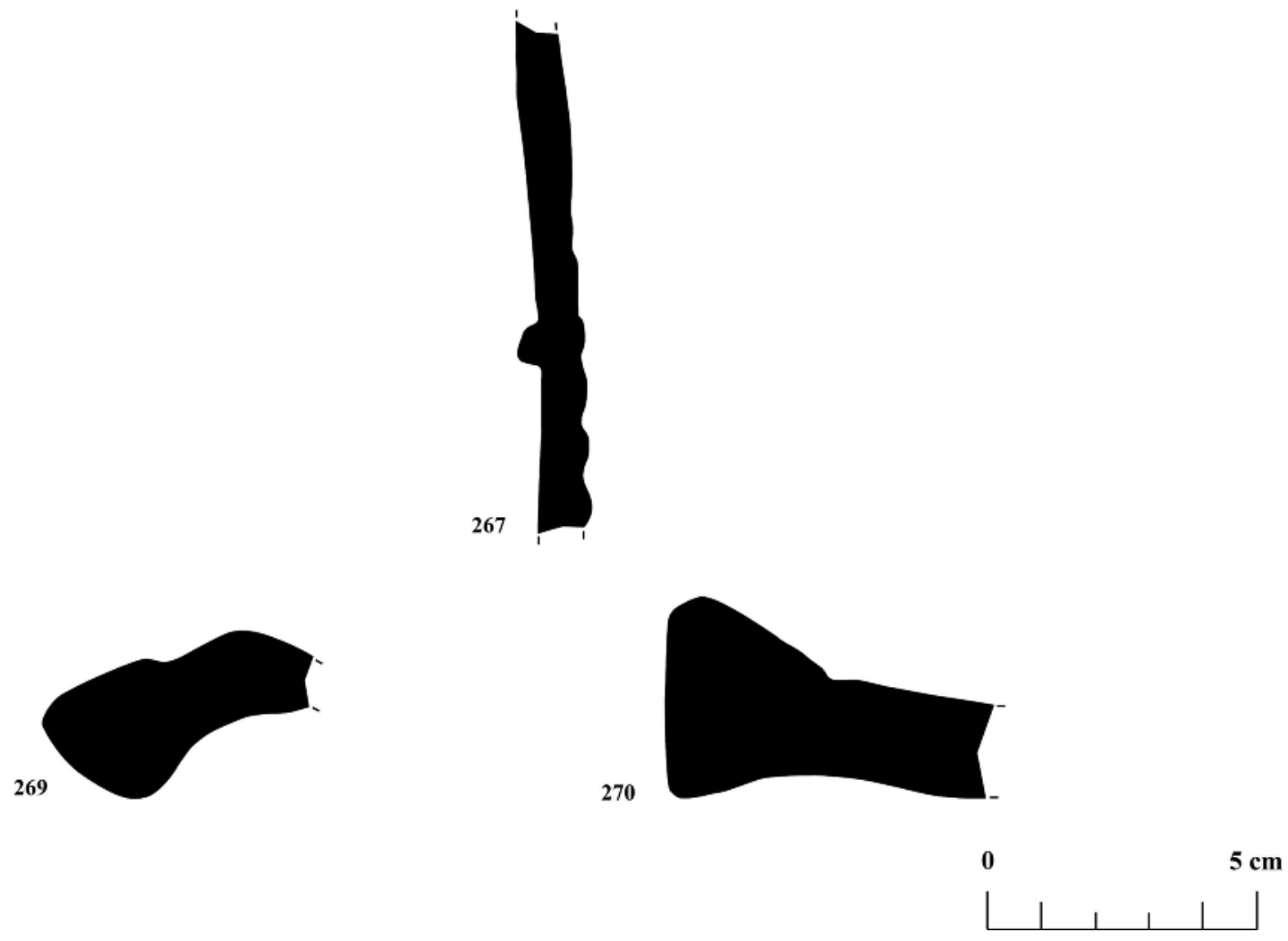

Pl. 20 : $\mathrm{N}^{\text {os }}$ 267-270 : Architectural ceramics; $n^{\circ}$ 267: A pipe fragment; and $n^{\text {os }}$ 269-270: Tile fragments.
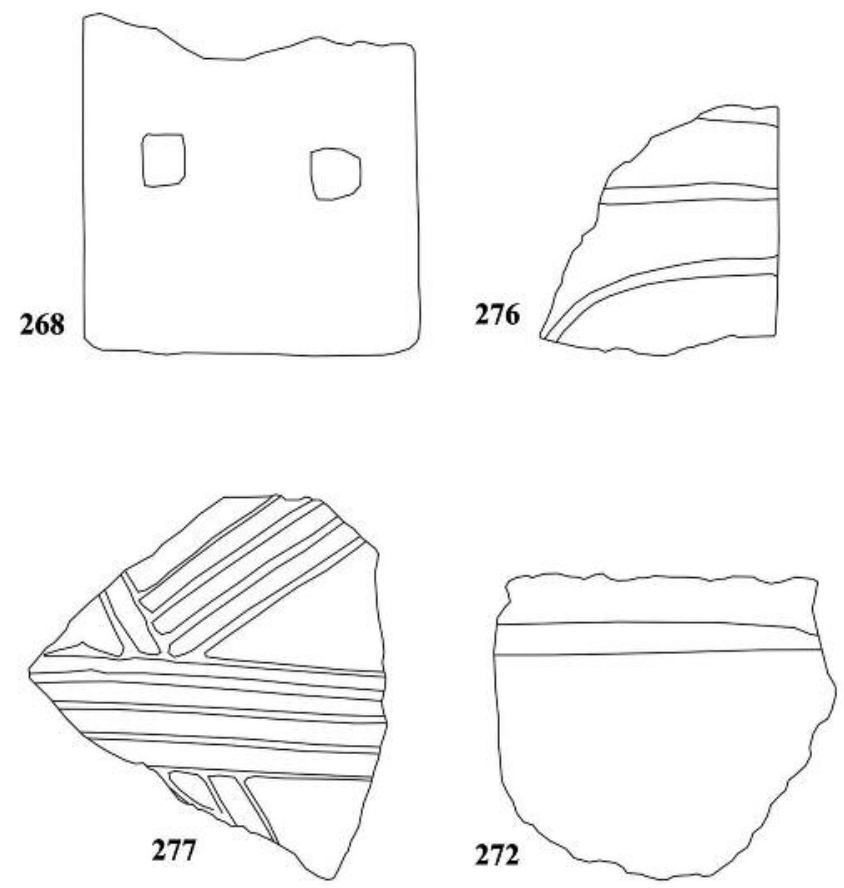

Pl. 21, $\mathrm{n}^{\text {os }}$ 268-277 : Architectural ceramics, $n^{0} 268$ : A brick fragment; and $\mathrm{n}^{\text {os }} \mathbf{2 7 2}$ as well as 276-277: Tile $\begin{array}{lllll}0 & 5 & 10 & 15 & 20 \\ 0\end{array}$ 
Decorated with three wavy finger grooves along two opposite edges and diagonally across surface from corner to corner 120

Light red (2.5YR 6/6), unslipped surface both on exterior and interior. Hard paste; sparsely porous, fine, light red (2.5YR 6/6) fabric with frequent lime as well as sand and small grit inclusions.

278- (No 1403): Tile fragment; Kimistene, Acropolis, northwestern slope of the temple, found in 2005 .

pl. 31/278.

Max. h 5.8 cm., max. w 9.0 cm., max. $110.5 \mathrm{~cm}$., $\max$. th $2.0 \mathrm{~cm}$.

Reddish yellow (5YR 6/6), unslipped surface both on exterior and interior. Soft paste; sparsely porous, fine, reddish yellow (5YR 6/6) fabric with some tiny lime as well as occasional sand and small grit inclusions.

279- ( $\mathrm{N}^{\circ}$ 1407): Tile fragment; Kimistene, found in 2005

pl. $31 / 279$.

Max. h $4.5 \mathrm{~cm}$., max. w $12.0 \mathrm{~cm}$., max. $110.2 \mathrm{~cm}$., $\max$. th $2.8 \mathrm{~cm}$.

Greyish brown (10YR 5/2), unslipped surface on exterior; yellowish red (5YR 5/6), unslipped surface in interior. Soft paste; non-porous, fine, reddish brown (5YR 4/4) fabric with some lime and small grit as well as rare mica inclusions.

\section{Pottery Finds after $12^{\text {th }}$ Cent. A.D.}

Especially from the debris of the Bath A we have some later sherds which were not being documented and left either in the Museum of Amasra or at the site depot. Among others a Turkish pipe of early $19^{\text {th }}$ cent. has been found in the debris of the Bath $\mathrm{A}$.

\section{CONCLUSIONS}

All of the Middle Byzantine pottery finds from southwestern Paphlagonia were treated in detail; their typologies, fabrics, hardness, wall thickness and surface treatments were identified and described individually. Numismatic finds are the major helpful benchmark for assessing region's chronology in combination with the pottery finds. The numismatic assemblage in southwestern Paphlagonia is very small, but it shows some traits that allow for preliminary interpretation.

Both the glazed and unglazed pottery finds show that southwestern Paphlagonia was connected with other parts of the Black Sea region. Although very few Middle Byzantine glazed fragments are found ${ }^{121}$, similar glazed decorated sherds to the ones from Kimistene are known from several sites around the Black Sea area, for instance in Bulgaria, Romania and along the Ukrainian coast, especially at Chersonesus and Azak ${ }^{122}$.

Traditional Roman coarse shapes were alive in Byzantine times, but with differences in fabric, typology and surface treatment; the most striking feature of the Middle Byzantine pottery is the continuity of forms throughout the entire period ${ }^{123}$. Firmly dated evidence from the Aegean and Saraçhane after the $7^{\text {th }}$ cent. A.D. shows a preference for closed round-bodied cooking pots in western Asia Minor. The same pattern is noted at Sagalassus in the $12^{\text {th }}$ $13^{\text {th }}$ cent. occupational layers, where flat-bottomed globular cooking pots with strap handles and a small rim diameter are the norm ${ }^{124}$. Apart from their meaning in terms of changing ceramic technology, economic and settlement patterns, new pottery forms in Middle Byzantine Paphlagonia, such as $\mathrm{n}^{\text {os }} 76-82$ on pl. 7, make us wonder whether they reflect a changing pattern in cooking practices and eating habits.

Middle Byzantine coarse pottery is represented in southern Black Sea area with kitchen or storage wares which cannot be dated more closely. So far very few Middle Byzantine deposits from the southern Black Sea area are known and only recently there are some field reports which offer some dates for

120) A similar fragment from Amorium: Witte 2012: 324, pl. 10/45, $\mathrm{n}^{\circ} 171$.

121) This is a common case for the entire Paphlagonia: Glatz and Düring 2015: 424.

122) Glazed tableware from Azov (Azak) in Rostov Oblast, Russia: Bocharov, Maslovskii and Sitdikov 2014: 29-31; PostByzantine pottery in Azov: Gusach 2014: 46-47; from the stratigraphical deposits of Kerch in Crimea, dated to $7^{\text {th }}-12^{\text {th }}$ cent. A.D.: Sazanov 1998: 61, figs. 41-44; glazed ceramics from Chersonesus in Crimea: Bocharov 2005: 306-311; Late Byzantine glazed ware from Chersonesus: Rabinowitz, Sedikova and Henneberg 2010: 450, figs. 25-36; as well as sgraffito glazed ware from a medieval shipwreck at Nový Svět near Chersonesus: Waksman and Teslenko 2010: 358-368.

123) Hayes 1992: 53.

124) Vionis et al. 2010: 460. 
these finds restrictedly ${ }^{125}$ : Eğriceova near Araç in the chora of Pompeiopolis at the altitude of $1530 \mathrm{~m}$ provides some evidences for Byzantine pottery ${ }^{126}$. In northeastern Paphlagonia in Cide the assemblage of the Byzantine ceramics is largely restricted to unglazed table and kitchen wares which indicate a peasant economy in the region ${ }^{127}$. They are from both the Middle as well as Late Byzantine periods ${ }^{128}$, and are dominated by medium to large jars and simple open bowls ${ }^{129}$. At Hamamtepe Höyük in the chora of Pontic Comana pottery of $10^{\text {th }}-11^{\text {th }}$ cent. A.D. is found, details of which are not clarified in published reports ${ }^{130}$. Some unique wares, such as 'Glazed White Wares' at Kaman-Kalehöyük in Central Anatolia clearly indicate some activities on this inland area during the Early and Middle Byzantine times ${ }^{131}$. Sagalassus is one of the very sites in Turkey chora of which is investigated systematically for its Byzantine phase and from where some pottery finds are reported ${ }^{132}$. Knowledge about Byzantine burial practices in Anatolia is also inconsistent, especially for southwestern Paphlagonia. The role of pottery in burial practises is therefore almost completely unknown ${ }^{133}$.

Serving equipment, such as deep or flat dishes by wood as well as glass drinking cups should had not been rare in the Late Roman-Early Byzantine inventories of household equipments in southwestern Paphlagonia. Such items tended to appear in houses, as found in large quantities in the domus ${ }^{134}$. Middle Byzantine vessel fragments found in Kimistine represent a domestic assemblage, produced in order to satisfy basic daily needs: cooking practices and eating habits, serving, transport and storage. What is striking is the larger proportion of closed vessels. The majority of the Middle Byzantine pottery at southwestern Paphlagonia seems to have been produced in locally, whereas we still need more information about their fabrics.
There are also some evidences that one can use for the settlement history of southwestern Paphlagonia during the Middle Byzantine period: in this region only few sites were continuously inhabited from Roman to Middle Byzantine times ${ }^{135}$. Nature of population changes in Hadrianoupolis during the Early Byzantine period is not known in detail; but it is clear that the city was re-populated during the mid $6^{\text {th }}$ and $7^{\text {th }}$ cent. A.D. It also exhibits a pattern commonly known from most parts of Asia Minor: a numismatic reduction, or even a gap, starting in A.D. $660 \mathrm{~s}$, and this lack of coinage is only overcome in A.D. 830s at the earliest as most of Anatolian sites. The hiatus in the assemblage here stretches even into the late $10^{\text {th }}$ cent., for which various reasons can be postulated. It is not necessary to connect this common gap with specific Arab incursions in A.D. 720s known from the written sources ${ }^{136}$, because it is typical for Asia Minor, and especially for Paphlagonia as a whole. As the lack of pottery finds shows, Hadrianoupolis belongs to the majority of Late Antique Anatolian towns that were abandoned during the mid $8^{\text {th }}$ cent. A.D. This fact can be deduced not only from the finds, but also from the etymology of the Turkish name of the later settlement: 'Viranșehir' (=ruinous city) resp. 'Eskipazar' (=old bazaar). At the so-called Acropolis of Byzantine Hadrianoupolis, i.e. Deliklikaya, which should had been used as a small Byzantine citadel during the Middle Byzantine period, there was neither a proper survey, nor an excavation; but one can assume that this building was used after $8^{\text {th }}$ cent. A.D. as a small garrison for the observation of the plain of Eskipazar. It is, however, not possible yet to suppose that Hadrianopoulis was transformed into a Byzantine kastron, as seen in some other Middle Byzantine sites $^{137}$. After the final Turkish-Seljuk conquest in the late $11^{\text {th }}$-early $12^{\text {th }}$ cent. the indigenous Byzantine population seems to have shifted mostly to the north,

125) Izdebski 2012: 60; and Vroom 2005: 14-16.

126) Özdoğan, Marro and Tibet 1999: 226.

127) Cassis 2015: 338 .

128) Cassis 2015: 327.

129) Glatz and Düring 2015: 388

130) Erciyas 2012: 170.

131) Vroom 2006: 168.

132) Vanhaverbeke et al. 2009 ; as well as Vanhaverbeke and Waelkens 2003: 304-305.

133) A recent contribution on this subject: Moore 2013.

134) Fünfschilling and Laflı 2012: 62.

135) Anderson 2008: 238

136) Ahrweiler 1962: 9 and 28; as well as Matthews, Metcalfe and Cottica 2009: 190-191.

137) Anderson and Robinson 2012: 21; as well as Matthews, Metcalfe and Cottica 2009: 182. For the Byzantine types of the urbanism (polis, kastron and other settlement types): Brubaker and Haldon 2011: 544-548; as well as Anderson 2009: $265-269$. 
to the new regional centre, Safranbolu (Theodoropolis; Taraklıborlu/Zalifre in early Turkish sources), where a Christian community existed until the beginning of $20^{\text {th }}$ cent. A.D. ${ }^{138}$.

Terracotta evidence in the form of both pottery and tile suggests the existence of an occupation at the observation post on the summit of the Acropolis of Kimistene in the Middle Byzantine period between late $9^{\text {th }} /$ early $10^{\text {th }}$ and late $11^{\text {th }} /$ early $12^{\text {th }}$ cent. This observation outpost was a small and poor settlement where little material culture survives, often undecorated body sherds that are very difficult to date. Kimistene was probably used for safe storage or defence during the extensive Turkish incursions into the region in $11^{\text {th }} / 12^{\text {th }}$ cent. A.D. Ceramics and tile clusters, as well as material remains in the landscape, including agricultural structures and others, speak to a continued Byzantine presence on the Acropolis of Kimistene as well as in few places around it over $150-200$ years between early $10^{\text {th }}$ and early $12^{\text {th }}$ cent. A.D. By the $12^{\text {th }}$ cent.A.D. most of the inland Anatolia including the Byzantine province of $\mathrm{Pa}$ phlagonia had come under the Turkish-Seljuk control, and only a narrow coastal strip with natural strongholds along southern Black Sea coast remained under Byzantine overlordship between A.D. 1181 and $1282^{139}$. According to some Byzantine authors wheat was abundantly produced in Paphlagonia during the Byzantine period, large tracts of which were suitable for agricultural purposes, especially for wheat and wine production ${ }^{140}$. During the Middle Byzantine period coastal Paphlagonia was, however, cut off from its interior agricultural hinterland which was involved in Late Antique agricultural practices. Thus, coastal Paphlagonia was only accessible from the sea; towns and citadels were forced to consume their grain and goods as effective as possible ${ }^{141}$.

The Paphlagonian sites collected at "Tabula Imperii Byzantini" by K. Belke in 1996 show an interesting feature of the distribution of the Byzantine fortified sites in this region ${ }^{142}$. The majority of them was located in the north, closer to the Black Sea than to central Anatolia, which may suggest that the actual role of these sites was to defend the access from the sea inland or to control the agricultural hinterland $\mathrm{d}^{143}$. Also Pompeiopolis was moved to a few kilometers away, to Kizkalesi on the crest of a hill where a Byzantine citadel was built with spoils ${ }^{144}$. Why the residents of Pompeiopolis left their city at the during of the $7^{\text {th }}$ cent. A.D., is still to be clarified. On the base of archaeological data in Kimistene it can be concluded that at the end of $11^{\text {th }} /$ beginning of $12^{\text {th }}$ cent. A.D. there was not a sudden abandonment, but rather a gradual decline. Nevertheless, Kimistene was one of the very few fortified Middle Byzantine sites in Paphlagonia from where small finds are published in detail. Wood must had been very popular as construction material in southwestern Paphlagonia during the Middle Byzantine period, and thus it is conceivable that neither in Hadrianoupolis, nor in Kimistene no wooden building left any trace, because they completely disappeared during the later Turkish periods.

There is almost no finds in southwestern $\mathrm{Pa}$ phlagonia which could be associated with the arrival of nomadic Turks/Seljuks and their presence in the territory in late $11^{\text {th }}$ and early $12^{\text {th }}$ cent. A.D. Archaeological appearance of the arrivals of Turks to southwestern Paphlagonia/Karabük needs a further and careful analysis.

\section{Notes and Acknowledgements}

All the plates of this paper were drawn and created the photographs by G. Kan Şahin (Çanakkale) from the photos, done by E. Lafl1 at the site in 20052008, except figs. 1-2, made in 2003 by the Directorate of the Museum of Ereğli in Zonguldak and figs. 1213 which were made by Dr William Anderson (Melbourne) in 2006 at the British Institute of Archaeology at Ankara, to both of whom we would like to express our gratitudes. The maps were produced by Dr Sami Patac1 (Ardahan) in 2014. We also would like to thank to Mr Aksel Tibet (Istanbul) for the edition of this article and to Dr Klaus Belke (Vienna) as well as Mr Max Ritter (Berlin) for their revisions.

In the catalogue section the numbers in brackets indicate find numbers of the field project. Abbreviations in the catalogue: th: thickness; h: height; w: width; d: diameter; 1: length; max.: maximum; and cent.: century. For this article The Munsell Soil Color Charts (2009) has been used. The frequency of the inclusions has been estimated according to the following principle: rare (1\%), few/occasional

138) Belke 1996: 268. For Safranbolu: Belke 1996: 187.

139) Booth 2004: 59 and map 4.

140) Teall 1959: 100 and n. 53.

141) Vroom 2015: 353; and Karpov 1993: 57.

142) Belke 1996

143) Izdebski 2012: 62.

144) Summerer and von Kienlin 2010: 124 
(3\%), some (5\%) and frequent (20\%). The size of the inclusions has been estimated as follows: small $(0.1<>0.2 \mathrm{~mm})$, medium $(0.2<>0.5 \mathrm{~mm})$, large $(0.5<1.0 \mathrm{~mm})$ and very large $(>1 \mathrm{~mm})$. Hardness was determined by a simple test: whether or not the fabric could be scratched by a fingernail or a metal point. The results are recorded as follows: soft (easily scratched by fingernail), medium hard (scratched by fingernail), and hard (scratched by metal point). These sherds are today being stored at the Museum of Amasra as well as at the container of the excavation site in Eskipazar.

E. L. and G. K. Ş.

\section{ABBREVIATIONS AND BIBLIOGRAPHY}

Ahrweiler, H., 1962: "L'Asie Mineure et les invasions arabes (VII'-IX ${ }^{\mathrm{e}}$ siècles)", Revue historique 227/1: 1-32.

Alvaro, C., Balossi, F. and Vroom, J., 2004: "Zeytinli Bahçe: A Medieval Fortified Settlement", Anatolia Antiqua XII: 191-213.

Anderson, W., 2008: "Settlement Change in Byzantine Galatia: An Assessment of Finds from General Survey of Central Anatolia", Anatolian Archaeological

Studies 17: 233-239< http://www.jiaa-

kaman.org/pdfs/aas_17/AAS_17_Anderson_W_pp_233 240.pdf $>(20 / 09 / 2015)$.

-2009: "Late Byzantine Occupation of the Castle at Tios", Anatolia Antiqua XVII: 265-277.

- 2011: Paphlagonia in Late Antiquity: Landscape and Material Culture in North-Central Anatolia (Unpubl. Diss.; The University of Melbourne).

Anderson, W. and Robinson, A., 2012: "Marginal or Mainstream? The Character of Settlement in Late Roman Paphlagonia", in Tsetskhladze, G.R., Laflı, E., Hargrave, J. and Anderson, W. (eds.), The Black Sea, Paphlagonia, Pontus and Phrygia in Antiquity. Aspects of Archaeology and Ancient History, British Archaeological Reports, International Series 2432, Oxford: 13-27.

Armstrong, P., 1996: "The Byzantine and Ottoman Pottery", in Cavanagh, W., Crouwel, J., Catling, R.W.V. and Shipley, G. (eds.), The Laconia Survey: Continuity and Change in a Greek Rural Landscape 2: Archaeological Data, The Annual of the British School at Athens 27: 125140 .

- 1998: "Nomadic Seljuks in 'Byzantine' Lycia: New

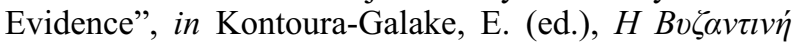

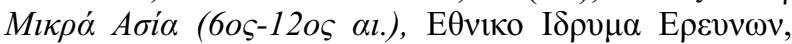

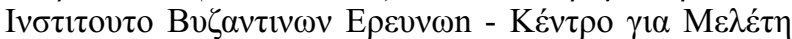

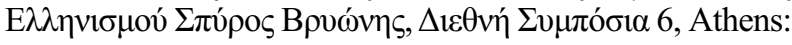
321-338.

- 2006: "Rural Settlement in Lycia in the Eighth Century: New Evidence", in Dörtlük, K., Varkıvanç, B., Kahya, T., des Courtils, J., Doğan Alparslan, M. and Boyraz, R. (eds.), The III' International Symposium on Lycia, 7-10 November 2005, Antalya, Symposium Proceedings, Antalya: 19-30.

Arthur, P., 2007: "Pots and Boundaries. On Cultural and Economic Areas between Late Antiquity and the Early Middle Ages", in Bonifay, M. and Tréglia, J. C. (eds.), LRCW 2. Late Roman Coarse Wares, Cooking Wares and Amphorae in the Mediterranean. Archaeology and Archaeometry, 1, British Archaeological Reports, International Series 1662, Oxford: 15-27.

- 2012: "Hierapolis of Phrygia: The Drawn-out Demise of an Anatolian City", in Christie, N. and Augenti, A. (eds.), Vrbes Extinctae, Archaeologies of Abandoned Classical Towns, Farnham, Surrey: 275-305.

Baird, D., 2004: "Settlement Expansion on the Konya Plain, Anatolia $5^{\text {th }}-7^{\text {th }}$ Centuries AD.", in Bowden, W., Lavan, L. and Machado, C. (eds.), Recent Research on the Late Antique Countryside, Late Antique Archaeology 2, Leiden/Boston, MA: 219-246.

Bakirtzis, Ch., 1980: "Didymoteichon: un centre de céramique post-byzantine", Balkan Studies 21/1: 147153.

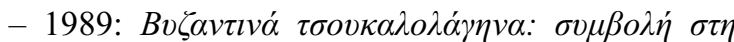

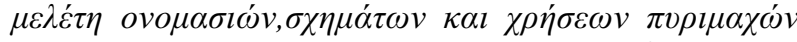

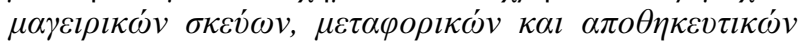
Soxcíwv / Byzantine Tsoukalolagena - A Contribution to the Study of the Names, Shapes and Uses of Fireproof Cooking Pots, Transport Vessels and Storage Containers,

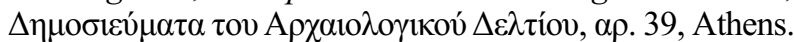

Bekker, I. (ed.), 1838: Theophanes Continuatus, Ioannes Cameniata, Symeon Magister, Georgius Monachus, Corpus scriptorum historiae byzantinae, Bonn.

Belke, K., 1996: Paphlagonien und Honōrias, Österreichische Akademie der Wissenschaften, Philosophischhistorische Klasse, Denkschriften 249, Tabula Imperii Byzantini 9, Vienna.

Bes, P., 2015: "The Cide Region in the Roman Period", in Düring, B. S. and Glatz, C. (eds.), Kinetic Landscapes, The Cide Archaeological Project 2009-2011: Surveying the Western Turkish Black Sea Region, Warsaw: 273-300.

Blake, H., 2005: "Review of J. Vroom's “After Antiquity: Ceramics and Society in the Aegean from the $7^{\text {th }}$ to the $20^{\text {th }}$ Century A.C.: A Case Study from Boeotia, Central Greece", (Archaeological Studies, Leiden University 10), Leiden 2003, Post-Medieval Archaeology 39/2: 454455 .

Bocharov S.G., Maslovskii A.N. and Sitdikov, A.G., 2014: "Glazed Tableware from Byzantine Provincial Centres as a Chronological Indicator for Crimean, Black Sea, and Eastern European Sites in 1250-1400", in: International Research Seminar, Glazed Wares in the Black Sea and Mediterranean as a Source for the Studies of Byzantine Civilizations. Abstracts. Tauric Chersonesos 
Preserve, Sevastopol, Russia, September $5^{\text {th }}-8^{\text {th }} 2014$, Sevastopol: 29-30.

Bocharov, S. G., 2005: "The Group of Byzantine Glazed Bowls of Second Part of the XIV th Century", in Botcharov, S. G. and Mytz, V. L. (eds.), Поливная керамика Срредиземноморъя и Пичерноморъя $X$ XVIII вв/Glazed Pottery of the Mediterranean and Black Sea Regions, $10^{\text {th }}-18^{\text {th }}$ Centuries, Kiev: 306-311.

Booth, I., 2004: "The Sangarios Frontier: The History and Strategic Role of Paphlagonia in Byzantine Defence in the Thirteenth Century", Byzantinische Forschungen 28: 45-86.

Böhlendorf-Arslan, B., 2012: "Pottery from the Destruction Contexts in the Enclosure", in Lightfoot, C. S. and Ivison, E. (eds.), Amorium Reports 3: The Lower City Enclosure. Finds Reports and Technical Studies, Istanbul: 153-179.

Brandes, W., 1989: Die Städte Kleinasiens im 7. und 8. Jahrhundert, Berliner byzantinistische Arbeiten 56, Berlin.

Brooks, E. W., 1901: “Arabic Lists of the Byzantine Themes", The Journal of Hellenic Studies 21: 67-77.

Broughton, T. R. S., 1938: "Roman Asia Minor", in Frank, T. (ed.), An Economic Survey of Ancient Rome 4: Roman Africa, Roman Syria, Roman Greece, Roman Asia, Baltimore, MD 1: 499-918.

Brubaker, L. and Haldon, J., 2011: Byzantium in the Iconoclast Era, c. 680-850: A History, Cambridge/New York.

Brüggemann, T., 2012: "Paphlagonia between Goths, Sasanids and Arabs ( $3^{\text {rd }}-8^{\text {th }}$ Centuries AD)", in Tsetskhladze, G.R., Lafl, E., Hargrave, J. and Anderson, W. (eds.), The Black Sea, Paphlagonia, Pontus and Phrygia in Antiquity. Aspects of Archaeology and Ancient History, British Archaeological Reports, International Series 2432, Oxford: 45-52.

Cassis, M., 2015: "The Cide and Şenpazar Region in the Byzantine Period", in Düring, B. S. and Glatz, C. (eds.), Kinetic Landscapes, The Cide Archaeological Project 2009-2011: Surveying the Western Turkish Black Sea Region, Warsaw: 301-344.

Charanis, P., 1975: "Cultural Diversity and the Breakdown of Byzantine Power in Asia Minor", Dumbarton Oaks Papers 29: 1-20.

Collins, C. A., 2012: Amphora Graffiti from the Byzantine Shipwreck at Novy Svet, Crimea (Unpubl. M.A. Thesis; University Texas A\&M) $<$ http://anthropology.tamu.edu/images/COLLINS-THESIS-2012.pdf $>$ $(20 / 09 / 2015)$

Cottica, D., 2007: "Micaceous White Painted Ware from insula 104 at Hierapolis", in Böhlendorf-Aslan, B., Uysal, A. O. and Witte-Orr., J. (eds.), Proceeding of the First International Symposion on Late Antique, Byzantine, Seljuk and Ottoman Pottery and Tiles in Archaeological Context, Çanakkale 31 May-3 June 2005, Çanak, Deutsches Archäologisches Institut, Abteilung Istanbul, Byzas 7, Istanbul: 255-272.

D'Amico, E., 2007: "Glazed White Ware in the Italian Peninsula" in Böhlendorf-Aslan, B., Uysal, A. O. and Witte-Orr., J. (eds.), Proceeding of the First International Symposion on Late Antique, Byzantine, Seljuk and Ottoman Pottery and Tiles in Archaeological Context, Çanakkale 31 May-3 June 2005, Çanak, Deutsches Archäologisches Institut, Abteilung Istanbul, Byzas 7, Istanbul: 215-238.

Degeest, R., 2000: The Common Wares of Sagalassos. Typology and Chronology, Studies in Eastern Mediterranean Archaeology III, Brepols 20.

De Staebler, P. D., 2012: "Roman Pottery", in Ratté, C. and de Staebler, P. D. (eds.), The Aphrodisias Regional Survey, Mainz on the Rhine: 59-87.

Dori, E., Velissariou, P. and Michailidis, M., 2003:

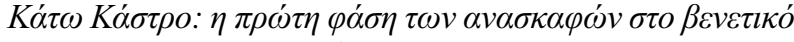

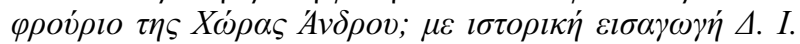

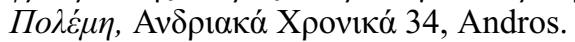

Devos, G., 2003: “The Pithoi”, in Devreker, J., Thoen, H. and Vermeulen, F. (eds.), Excavations in Pessinus: The So-Called Acropolis. From Hellenistic and Roman Cemetery to Byzantine Castle, Archaeological Reports Ghent University 1, Ghent: 369-374.

Doğer, L., 2007: "Byzantine Ceramics: Excavations at Smyrna Agora (1997-98 and 2002-03)", in Böhlendorf-Aslan, B., Uysal, A. O. and Witte-Orr., J. (eds.), Proceeding of the First International Symposion on Late Antique, Byzantine, Seljuk and Ottoman Pottery and Tiles in Archaeological Context, Çanakkale 31 May-3 June 2005, Çanak, Deutsches Archäologisches Institut, Abteilung Istanbul, Byzas 7, Istanbul: 97-122.

- 2015: "Late Byzantine and Ottoman Pottery from Nif-Olympus", in Lafl, E. and Patac1, S. (eds.), Recent Studies on the Archaeology of Anatolia, British Archaeological Reports, International Series 2750, Oxford: 57-69.

Duman, B., 2014: "A Group of Local Production Middle Byzantine Period Pottery from Tripolis", Anatolia Antiqua XXII: 225-234.

Dunn, A., 1994: "'The Transition from polis to kastron in the Balkans (III-VII cc.): General and Regional Perspectives", Byzantine and Modern Greek Studies 18/1: 60-80.

Düring, B., Şerifoğlu, T. E. and Glatz, C., 2012: "2010 Cide Arkeoloji Projesi: İkinci Sezon Sonuçları", AST 29/3: 237-250.

Erciyas, D. B., 2012: "Komana ve Çevresinde Çağlar Boyu Yerleşim", in Akyol, A. A. and Özdemir, K. (eds.), Two Eminent Contributors to Archaeometry in Turkey. To Honour of Prof. Dr. Ay Melek Özer and Prof. Dr. Şahinde Demirci, Istanbul: 163-170.

— 2013: "Komana/Sisiye'de Bir Orta Çağ İşliği: Bizans'dan Danişmentliler'e Tokat'ın Değişen Çehresi", in Dönmez, Ş. (ed.), Lux ex Ponto Euxino. Studies Presented in Honour of Sümer Atasoy, Ankara: 141-158.

- 2014: "A Middle Byzantine Citadel at Komana", in Bekker-Nielsen, T. (ed.), Space, Place and Identity in Northern Anatolia, Geographica Historica 27, Stuttgart: 215-225.

Erciyas, B., Sökmen, E. and Kocabıyık, C., 2011: "Komana Antik Kenti 2009 Yılı Kazı Çalışmaları", KST 32/4: 121-132. 
Fatouros, G. (ed.), 1992: Theodori Studitae Epistulae, Corpus fontium historiae Byzantinae, Series Berolinensis 31, Berlin.

Ferrazzoli, A. F. and Ricci, M., 2010a: "Un centro di produzione delle anfore LR 1: Elaiussa Sebaste in Cilicia (Turchia). Gli impianti, le anfore", in Menchelli, S., Santoro, S., Pasquinucci, M. and Guiducci, G. (eds.), LRCW3. Late Roman Coarse Wares, Cooking Wares and Amphorae in the Mediterranean: Archaeology and Archaeometry, British Archaeological Reports, International Series 2185, Oxford: 815-826.

-2010b: "Le produzioni di ceramiche comuni decorate di età protobizantina di Elaiussa Sebaste in Cilicia", in Menchelli, S., Santoro, S., Pasquinucci, M. and Guiducci, G. (eds.), LRCW3. Late Roman Coarse Wares, Cooking Wares and Amphorae in the Mediterranean: Archaeology and Archaeometry, British Archaeological Reports, International Series 2185, Oxford: 803-813.

Foss, C., 1979: Ephesus after Antiquity: A Late Antique, Byzantine and Turkish City, Cambridge.

Fünfschilling, S. and Laflı, E., 2012: Hadrianoupolis II: Glasfunde des 6. und 7. Jhs. aus Hadrianupolis, Paphlagonien [Türkei], Internationale Archäologie 123, Rahden/Westf.

Fulfort, M. G., 1984: "The Coarse (Kitchen and Domestic) and Painted Wares", in Fulford, M. G. and Peacock, D. P. S. (eds.), Excavations at Carthage: The British Mission I, 2, The Avenue du President Habib Bourguiba, Salammbo: The Pottery and Other Ceramic Objects from the Site, Sheffield: 155-231.

Gabrieli, R. S., 2007: “A Region apart: Coarse Ware of Medieval and Ottoman Cyprus", in Böhlendorf-Aslan, B., Uysal, A. O. and Witte-Orr., J. (eds.), Proceeding of the First International Symposion on Late Antique, Byzantine, Seljuk and Ottoman Pottery and Tiles in Archaeological Context, Çanakkale 31 May-3 June 2005, Canak, Deutsches Archäologisches Institut, Abteilung Istanbul, Byzas 7, Istanbul: 399-410.

-2008: "Towards a Chronology-The Medieval Coarse Ware from the Tombon Icarus Street, Kato Pafos", Report of the Department of Antiquities, Cyprus: 423-454.

Glatz, C., and Düring, B. S., 2015: "A Tale of Three Landscapes: Okçular, Abdulkadir, and Çamdibi in LongTerm Perspective", in Düring, B. S. and Glatz, C. (eds.), Kinetic Landscapes, The Cide Archaeological Project 2009-2011: Surveying the Western Turkish Black Sea Region, Warsaw: 377-428.

Gusach, I. R., 2014: "The Products of Post-Byzantine Pottery Workshops of the Crimea in Azak", in: International Research Seminar, Glazed Wares in the Black Sea and Mediterranean as a Source for the Studies of Byzantine Civilizations. Abstracts. Tauric Chersonesos Preserve, Sevastopol, Russia, September $5^{\text {th }}-8^{\text {th }}$ 2014, Sevastopol: 46-47.

Günsenin, N., 1989: "Recherches sur les amphores byzantines dans les musées turcs", in Déroche, V. and Spieser, J.-M. (eds.), Recherches sur la céramique byzantine: Actes du colloque organisé par l'Ecole française d'Athènes et l'Université de Strasbourg II, Centre de recherches sur l'Europe centrale et sud-orientale, Athènes 8-10 avril 1987, Bulletin de Correspondence Hellénique, Supplement XVIII, Paris: 267-276.

- 1993: "Ganos. Centre de production d'amphores à l'époque byzantine", Anatolia Antiqua II: 193-201.

Hayes, J. W., 1992: Excavations at Saraçhane in Istanbul 2: The Pottery, Princeton, NJ.

Honigmann, E. (ed.), 1939: Le Synekdémos d'Hiéroklès et l'opuscule géographique de Georges de Chypre: texte, introduction, commentaire et cartes, Editions de l'Institut de philologie et d'histoire orientales et slaves, Brussels.

Intagliata, E. E., 2014: "The White Ware from Palmyra (Syria): Preliminary Date from the New Excavations in the South-West Quarter", in Poulou-Papadimitriou, N., Nodarou, E. and Kilikoglou, V. (eds.), LRCW 4. Late Roman Coarse Wares, Cooking Wares and Amphorae in the Mediterranean. Archaeology and Archaeometry, The Mediterranean: a Market without Frontiers, British Archaeological Reports, International Series 2616 (I), Oxford: 649-655.

Ivison, E. A., 2007: "Amorium in the Byzantine Dark Ages (Seventh to Ninth Centuries)", in Henning, J. (ed.), Post-Roman Towns, Trade and Settlement in Europe and Byzantium 2, Millennium-Studien 5/2, Berlin/New York: 25-60.

- 2012: "Excavations at the Lower City Enclosure, 1996-2008", in Lightfoot, C. S. and Ivison, E. (eds.), Amorium Reports 3: The Lower City Enclosure. Finds Reports and Technical Studies, Istanbul: 5-151.

Izdebski, A., 2012: "The Changing Landscapes of Byzantine Northern Anatolia”, Archaeologia Bulgarica 16/1: 47-66.

Japp, S., 2010: “Late Roman, Byzantine and Ottomon Pottery from Alexandria Troas", in Böhlendorf-Aslan, B., Uysal, A. O. and Witte-Orr., J. (eds.), Proceeding of the First International Symposion on Late Antique, Byzantine, Seljuk and Ottoman Pottery and Tiles in Archaeological Context, Çanakkale 31 May-3 June 2005, Çanak, Deutsches Archäologisches Institut, Abteilung Istanbul, Byzas 7, Istanbul: 55-72.

Jones, A. H. M., 1971: The Cities of the Eastern Roman Provinces ( $2^{\text {nd }}$ edition), Oxford.

Kan Şahin, G., and Laflı, E., 2015: "Roman and Late Roman-Early Byzantine Coarse Ware from southwestern Paphlagonia", in Lafl, E. and Patac1, S. (eds.), Recent Studies on the Archaeology of Anatolia, British Archaeological Reports, International Series 2750, Oxford: 327437.

Kaptijn, E., Poblome, J., Vanhaverbeke, H., Bakker, J. and Wealkens, M., 2013: "Social Changes in the Hellenistic, Roman and Early Byzantine Periods. Result from the Sagalassos Territorial Archaeological Survey 2008 (Southwest Turkey)", Anatolian Studies 63: 75-95.

Karpov, S. P., 1993: "The Grain Trade in the Southern Black Sea Region: The Thirteenth to the Fifteenth Century", Mediterranean Historical Review 8/1: 55-73.

Kazhdan, A. P. (ed.), 1991: The Oxford Dictionary of Byzantium, New York/Oxford. 
Kirilov, C., 2007: "The Reduction of the Fortified City Area in Late Antiquity: Some Reflections on the End of the "Antique City" in the Lands of the Eastern Roman Empire", in Henning, J. (ed.), Post-Roman Towns, Trade and Settlement in Europe and Byzantium 2, Millennium-Studien 5/2, Berlin/New York: 3-24.

Lafl1, E., 2012: "Archäologische Evidenzen zum Weinanbau im südwestlichen Paphlagonien in römischer und frühbyzantinischer Zeit", in Olshausen, E. and Sauer, V. (eds.), Die Schätze der Erde. Natürliche Ressourcen in der antiken Welt. Stuttgarter Kolloquium zur Historischen Geographie des Altertums 10, 2008, Geographica Historica 28, Stuttgart: 261-279.

Lafl1, E. and Christof, E., 2011: "Der kaiserzeitliche Tempel von Asartepe/Kimistene in der Chora des paphlagonischen Hadrianoupolis - Ergebnisse der Prospektion von 2005", Istanbuler Mitteilungen: 233-285.

Lafl, E. and Kan Şahin, G., 2010: "Hadrianoupolis ve Çevresinden Geç Ortaçağ Sırlı Seramik Örnekleri”, in Pektaş, K., Cirtil, S., Özgün Cirtil, S., Öztaşkın, G. K., Özdemir, H., Aktuğ, E. and Uykur, R. (eds.), Proceedings of the XIII ${ }^{\text {th }}$ Symposium of Medieval and Turkish Period Excavations and Art Historical Researches, 14-16 October 2009, Istanbul: 427-432.

- 2012: "Terra Sigillata and Red-Slipped Ware from Hadrianoupolis in southwestern Paphlagonia", Anatolica Antiqua XX: 45-120.

- 2013: "Pottery from Southwestern Paphlagonia II: Unguentaria and Lamps", in Ramminger, B., Stilborg, O. and Helfert, M. (eds.), Naturwissenschaftliche Analysen vor- und frühgeschichtlicher Keramik III. Methoden, Anwendungsbereiche, Auswertungsmöglichkeiten. Universitätsforschungen zur prähistorischen Archäologie aus der Abteilung Vor- und Frühgeschichtliche Archäologie der Universität Hamburg 238, Bonn: 353-378.

- 2014: "Hellenistic Ceramics from Southwestern Paphlagonia", Anatolica Antiqua XXII: 51-144.

Lafl, E., Kan Şahin, G. and Patac1, S., 2013: "Iron Age Ceramics from Southwestern Paphlagonia", Anatolia Antiqua XXI: 33-68.

Lafl, E. and Zäh, A., 2008: "Archäologische Forschungen im byzantinischen Hadrianupolis in Paphlagonien", Byzantinische Zeitschrift 101/2: 681-714 and pls. XIIIXXVI.

Lamberz, E., 2004: Die Bischofslisten des VII. ökumenischen Konzils (Nicaenum II), Bayerische Akademie der Wissenschaften, Philosophisch-Historische Klasse, Abhandlungen, n.F. 124, Munich.

Laurent, V., 1965: Le corpus des sceaux de l'empire byzantin V, 2: L'église. Première partie (suite); I. L'église de Constantinople, le clergé et les moines; II. Les archevêchés autocéphales (Chypre et Bulgarie) - Deuxième partie; I. Les patriarcats orientaux (Alexandrie, Antioche, Jérusalem); II. Supplément, Publications de l'Institut français d'etudes byzantines, Paris.

Lightfoot, C. S., 2007: "Trade and Industry in Byzantine Anatolia, The Evidence from Amorium", Dumbarton Oaks Papers 61: 269-286.
Lightfoot, C. S., Arbel, Y., Böhlendorf-Arslan, B., Roberts, J. A. and Witte-Orr, J., 2004: "The Amorium Project: Excavation and Research in 2001", Dumbarton Oaks Papers 58: 355-370.

Lightfoot, C. S. and Ivison, E. A., 1996: “Amorium Excavations 1995: The Eighth Preliminary Report", Anatolian Studies 46: 91-110.

Lounghis, T. C., 1998: "The Evolution of Thematic Encounters in Asia Minor and the Reign of Michael II",

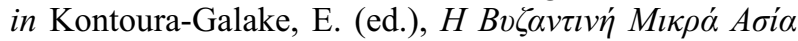

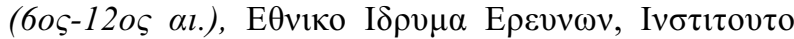

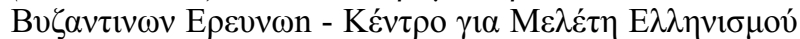

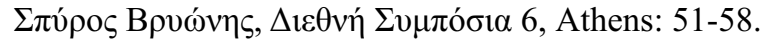

Makris, G., 2002: "Ships", in Laiou, A. E. (ed.), The Economic History of Byzantium: From the Seventh through the Fifteenth Century, Dumbarton Oaks Studies 39, Washington, D.C.: 91-100.

Matthews, R., Metcalfe, M. and Cottica, D., 2009 "Landscapes with Figures: Paphlagonia through the Hellenistic, Roman and Byzantine Periods, 330 B.C.-A.D. 1453", in Matthews, R. and Glatz, C. (eds.), At Empire's Edge: Project Paphlagonia. Regional Survey in NorthCentral Turkey, British Institute of Archaeology at Ankara, Monograph 44, London: 173-199 and 216-226.

McGeer, E., Nesbitt, J. W. and Oikonomides, N. (eds.), 2001: Catalogue of Byzantine Seals at Dumbarton Oaks and in the Fogg Museum of Art, Vol. 4: The East, Washington, D.C.

McNicoll, A., 1973: "Taşkun Kale”, in "Aşvan 19681972: An Interim Report”, Anatolian Studies 23: 159180.

Mimaroğlu, S., 2010: "Panaztepe Bizans Dönemi Sırsız Seramikleri”, in Pektaş, K., Cirtil, S., Özgün Cirtil, S., Öztaşkın, G. K., Özdemir, H., Aktuğ, E. and Uykur, R. (eds.), Proceedings of the XIII ${ }^{\text {th }}$ Symposium of Medieval and Turkish Period Excavations and Art Historical Researches, 14-16 October 2009, Istanbul: 443-452.

- 2011: "Kadıkalesi/Anaia Bizans Dönemi Amphoraları", Sanat Tarihi Dergisi 20/1: 63-92.

Mitchell, S., 1993: Anatolia: Land, Men and Gods in Asia Minor. 2: The Rise of the Church, Oxford.

Moore, S. V., 2013: A Relational Approach to Mortuary Practices within Medieval Byzantine Anatolia (Unpubl. $\mathrm{PhD}$ thesis; Newcastle University).

Moravcsik, G. and Jenkins, R. J. H. (eds. and trans.), 1985: Constantine Porphyrogenitus De administrando imperio, Corpus fontium historiae Byzantinae, Consilio Societatis internationalis studiis Byzantinis provehendis destinatae editum 1, Dumbarton Oaks Texts I ( $2^{\text {nd }}$ edition), Washington, D.C.

Müller-Wiener, W., 1986: "Von der Polis zum Kastron. Wandlungen der Stadt im Ägäischen Raum von der Antike zum Mittelalter", Gymnasium 93: 435-475.

Naumann C., Kleem, V. and Kuhn, H. J., 1988: Das Byzantinische Reich, die Sal̆̄ūqen und Kreuzfahrer, Tübinger Atlas des Vorderen Orients, Blatt B VII 19, Wiesbaden. 
Niewöhner, P., 2003: "Welkende Städte in blühendem Land? Aizanoi und die Verländlichung Anatoliens im 5./6. Jh. n. Chr. Vorbericht über eine Untersuchung im Umland von Aizanoi", Archäologischer Anzeiger 2003/1: 221-228.

- 2007: “Archäologie und die 'Dunklen Jahrhunderte' im byzantinischen Anatolien", in Henning, J. (ed.), PostRoman Towns, Trade and Settlement in Europe and Byzantium 2, Millennium-Studien 5/2, Berlin/New York: 119-158.

Oikonomides, N., 1972: Les listes de préséance Byzantines des IXe et $X^{e}$ siècles. Introduction, texte et commentaire (Le monde byzantine), Paris.

Özdoğan, A., Marro, C. and Tibet, A., 1999: "Kastamonu Yüzey Araştırması 1997 Yılı Çalışmaları”, AST 16/2: 219-244.

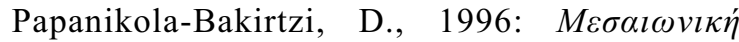

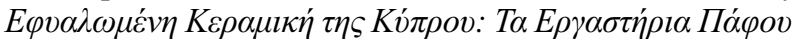

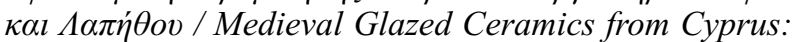
Paphos and Lapithos Ware, Thessaloniki.

- 1999: Byzantine Glazed Ceramics: The Art of Sgraffito, Athens.

- (ed.), 2002: Everyday Life in Byzantium, Byzantine Hours - Works and Days in Byzantium, Exhibition Catalogue, Thessaloniki, White Tower, October 2001 - January 2002, Athens.

Parshina, E. A., 2001: "Kleimennaja vizantiiskaja amphora X v. iz Laspi / Stamped Byzantine Amphorae of $10^{\text {th }}$ c. A.D. from Laspi", in Torgivla, M. (ed.), Sea Trade in North Black Sea Region. The Collection of Scientific Articles, Kiev: 104-117 (in Ukranian with an abstract in English)

Peña, J. T., 2007: Roman Pottery in the Archaeological Record, Cambridge/New York.

Pertusi, A. (ed.), 1952: Constantino Porfirogenito, De thematibus, Bibliotheca apostolica vaticana, Studi e testi 160, Vatican City.

Rabinowitz, A., Sedikova, L. and Henneberg, R., 2010: "Daily Life in a Provincial Late Byzantine City: Recent Multidisciplinary Research in the South Region of Tauric Chersonesos (Cherson)", in Daim, F. and Drauschke, J. (eds.), Byzanz-das Römerreich im Mittelalter. Teil 1: Welt der Ideen, Welt der Dinge, Monographien des Römisch-Germanischen Zentralmuseums 84/1, Mainz on the Rhine: $425-478$.

Ratté, C., 2001: "New Research on the Urban Development of Aphrodisias in Late Antiquity", in Parrish, D. (ed.), Urbanism in Western Asia Minor. New Studies on Aphrodisias, Ephesos, Hierapolis, Pergamon, Perge and Xanthos, Journal of Roman Archaeology. Supplementary Series 45, Portsmouth, RI: 116-147.

Redford, S., 1986: "Excavations at Gritille (19821984): The Medieval Period. A Preliminary Report", Anatolian Studies 36: 103-136.

Rice, P. M., 1987: Pottery Analysis: A Sourcebook, Chicago, IL.

Riplinger, T. et al., 1988: Kleinasien. Das Byzantinische Reich (7.-9. Jh.), Tübinger Atlas des Vorderen Orients, Blatt B VI 8, Wiesbaden.
Romančuk, A. I., 2005: Studien zur Geschichte und Archäologie des byzantinischen Cherson, Colloquia Pontica 11, Leiden/Boston, MA.

Ruggiu, A. Z. and Cottica, D., 2007: "Hierapolis di Frigia fra tarda antichità ed XI secolo: l'apporto dello studio degli spazi domestici nell'insula 104", Rivista di archeologia 31: 139-189 and figs. XXVI-XLIX.

Sanders, G. D. R., 1987: “An Assemblage of Frankish Pottery at Corinth", Hesperia 56: 159-195.

- 2000: "New Relative and Absolute Chronologies for $9^{\text {th }}$ to $13^{\text {th }}$ Century Glazed Wares at Corinth: Methodology and Social Conclusions", in Belke, K., Hild, F., Köder, J. and Soustal, P. (eds.), Byzanz als Raum: Zu Methoden und Inhalten der Historischen Geographie des Östlichen Mittelmeerraumes, Österreichische Akademie der Wissenschaften, Philosophisch-Historische Klasse, Denkschriften 283/Veröffentlichungen der Kommission für die Tabula Imperii Byzantini 7, Vienna: 153-173.

- 2003: "Recent Developments in the Chronology of Byzantine Corinth", Corinth. The Centenary: 1896-1996, 20: 385-399.

Sazanov, A., 1998: "The Stratigraphic Chronology of Medieval Kerch (VIII-XII Centuries A.D.)", Russian Academy of Sciences, Institute of Archaeology, Magnitogorsk State Pedogogical Institute, Journal of Historical, Philological and Cultural Studies 5: 50-88 (in Russian with an abstract in English on p. 88).

Summerer, L. and von Kienlin, A., 2010: "Pompeiopolis. The Metropolis of Paplagonia", in Bru, H. and Labarre, G. (eds.), L'Anatolie des peuples, des cités et des cultures (II millénaire av. J.-C. - V siècle ap. J.-C.). Colloque international de Besançon - 26-27 novembre 2010. Vol. II: Approches locales et régionales, Besançon: 115-126.

Summerer, L., von Kienlin, A. and Herdt, G., 2010: "Pompeiopolis 2008 Yılı Kazı Çalışmaları", in KST 31/1: 421-440.

Symington, D. and Collon, D., 2007: "Spindle Whorls", in Thomas, D. and Postgate, J. N. (eds.), Excavations at Kilise Tepe, 1994-98. From Bronze Age to Byzantine in Western Cilicia, Mcdonald Institute Monographs 30/British Institute of Archaeology at Ankara, Monograph 30, London/Cambridge: 481-498.

Teall, J. L., 1959: "The Grain Supply of the Byzantine Empire, 330-1025”, Dumbarton Oaks Papers 13: 87139.

Todorova, E., 2011: "The Medieval Amphorae (Ninth to Fourteenth Centuries AD) from Excavation at Silistra in 2007 (Preliminary Report)", in Tzochev, C., Stoyanov, T. and Bozkova, A. (eds.), Patabs II, Production and Trade of Amphorae in the Black Sea, Acts of the International Round Table held in Kiten, Nessebar and Sredetz, September 26-30, 2007, Sofia: 131-140 and pls. 1-3.

Tekinalp, V. M. and Ekim, Y., 2005: Sazpegler, Kuzeydoğu Anadolu'da Bir Ortaçă̆ Yerleşimi/Sazpegler. A Medieval Settlement in North Eastern Anatolia, Gazi University Research Center for Archaeology, Baku-Tbilisi-Ceyhan Crude Oil Pipeline Project Publications of Archaeological Salvage Excavations 3, Ankara. 
Toydemir Sabuncu, A., 2011: "Bizans Dönemi ÇanakÇömlek Buluntuları", in Atasoy, S. and Yıldırım, Ş., "Filyos-Tios 2009 Y11 Kazısı", in KST 32/4: 5-8 and figs. 1-4.

Treadgold, W., 1988/1989: "Three Byzantine Provinces and the First Byzantine Contacts with the Rus", Harvard Ukrainian Studies 12/13, 1988/1989 [=Pritsak, O. and Ševčenko, I. (eds.), Proceedings of the International Congress Commemorating the Millennium of Christianity in Rus'-Ukraine, Cambridge, MA: 132-144.

- 1997: A History of the Byzantine State and Society, Stanford, Santa Clara County, CA.

Türker, A. C.., 2005: “Gelibolu'da Bizans Seramikleri ve Ökaristik Ekmek Damgası”, Hacettepe Üniversitesi Edebiyat Fakültesi Dergisi 22/2: 87-104.

- 2006: "Bizans Dönemi Demre-Myra Sirsız Seramik Buluntular1", Adalya 9: 155-169.

Vanhaverbeke, H., Vionis, A. K., Poblome, J. and Waelkens, M., 2009: "What Happened after the $7^{\text {th }}$ Century AD? A Different Perspective on Post-Roman Rural Anatolia", in Vorderstrasse, T. and Roodenberg, J. (eds.), Archaeology of the Countryside in Medieval Anatolia, Publications de l'Institut historique-archéologique néerlandais à Stamboul, Pihans 113, Leiden: 177-190.

Vanhaverbeke, H., Martens, F., and Waelkens, M., 2007: "Another View on Late Antiquity: Sagalassos (SW Anatolia), its Suburbium and its Countryside in Late Antiquity", Proceedings of the British Academy 141: 611648.

Vanhaverbeke, H. and Waelkens, M., 2003: The Chora of Sagalassos: The Evolution of the Settlement Pattern from Prehistoric until Recent Times, Studies in Eastern Mediterranean Archaeology 5, Turnhout.

Vermeulen, F., 2003: "Conclusions", in Devreker, J., Thoen, H. and Vermeulen, F. (eds.), Excavations in Pessinus: The So-Called Acropolis. From Hellenistic and Roman Cemetery to Byzantine Castle, Archaeological Reports Ghent University 1, Ghent: 382-387.

Vionis, A. K., 2001: "Post-Roman Pottery Unearthed: Medieval Ceramics and Pottery Research in Greece", Medieval Ceramics 25: 84-98.

- 2006a: "The Archaeology of Ottoman Villages in Central Greece: Ceramics, Housing, and Everyday Life in Post-Medieval Rural Boeotia", in Erkanal-Öktü, A., Özgen, E., Günel, S., Ökse, A. T., Hüryılmaz, H., Tekin, H., Çinardal1-Karaaslan, N., Uysal, B., Karaduman, F. A., Engin, A., Spieß, R., Aykurt, A., Tuncel, R., Deniz, U. and Rennie, A. (eds.), Studies in Honor of Hayat Erkanal: Cultural Reflections, Istanbul: 784-800.

- 2006b: "The Thirteenth to Sixteenth Century Kastro of Kephalos: A Contribution to the Archaeological Study of Medieval Paros and the Cyclades", The Annual of the British School at Athens 101: 459-492.

- 2013: "Considering a Rural and Household Archaeology of the Byzantine Aegean: The Ceramic Spectrum", in Bintliff, J. and Caroscio, M. (eds.), Pottery and Social Dynamics in the Mediterranean and Beyond in Medieval and Post-Medieval Times, British Archaeological Reports, International Series 2557, Oxford: 25-40.
Vionis, A. K., Poblome, J. and Waelkens, M., 2009: "The Hidden Material Culture of the Dark Ages. Early Medieval Ceramics at Sagalassos (Turkey): New Evidence (ca A.D. 650-800)", Anatolian Studies 59: 147-165.

Vionis, A. K., Poblome, J., de Cupere, B. and Waelkens, M., 2010: “A Middle-Late Byzantine Pottery Assemblage from Sagalassos: Typo-Chronology and Sociocultural Interpretation", Hesperia 79: 423-464.

Von Wartburg M. L., 2007: "Chronology and Stratigraphy of the Medieval Pottery of Cyprus: A Critical Rewiew", in Böhlendorf-Aslan, B., Uysal, A. O. and Witte-Orr., J. (eds.), Proceeding of the First International Symposion on Late Antique, Byzantine, Seljuk and Ottoman Pottery and Tiles in Archaeological Context, Çanakkale 31 May-3 June 2005, Çanak, Deutsches Archäologisches Institut, Abteilung Istanbul, Byzas 7, Istanbul: 419-440.

Vroom, J., 1998: "Medieval and Post-Medieval Pottery from a Site in Boeotia: A Case Study Example of PostClassical Archaeology in Greece", The Annual of the British School at Athens 93: 513-546.

- 2003: After Antiquity: Ceramics and Society in the Aegean from the $7^{\text {th }}$ to the $20^{\text {th }}$ Century A.C. A Case Study from Boeotia, Central Greece, Archaeological Studies, Leiden University 10, Leiden.

- 2004: "Late Antique Pottery, Settlement, and Trade in the Eastern Mediterranean: A Preliminary Comparison of Ceramics from Limyra (Lycia) and Boeotia", in Bowden, W., Lavan, L. and Machado, C. (eds.), Recent Research on the Late Antique Countryside, Late Antique Archaeology 2, Leiden/Boston, MA: 281-331.

- 2005: "Medieval Pottery from the Artemision in Ephesus: Imports and Locally Produced Wares", in Krinzinger, F. (ed.), Spätantike und Mittelalterliche Keramik aus Ephesos, Österreichische Akademie der Wissenschaften, Philosophisch-historische Klasse, Denkschriften 332, Archäologische Forschungen 13, Vienna: 17-49.

- 2006: "Some Byzantine Pottery Finds from Kaman-Kalehöyük: A First Observation", Anatolian Archaeological Studies 15: 163-169.

- 2007: "Limyra in Lycia: Byzantine/Umayyad Pottery Finds from Excavations in the Eastern Part of the City", in Lemaître, S. (ed.), Les produits et les marchés. Céramique antique en Lycie (VII ${ }^{e}$ s. av. J.C. $-V I I^{e}$ s. ap. J.-C.). Actes de la table ronde de Poitiers (21-22 mars 2003), Études 16, Bordeaux: 261-292.

- 2008: "Preliminary Report on the Pottery from the Avkat Archaeological Project, 2007-08: Byzantine to Ottoman", in Haldon, J., Elton, H., Newhard, J., Vroom, J., Anderson, J. W. and Stahl, A. (eds.), The Avkat Archaeological Project, The Second Season, July-August 2008:

Preliminary Summary Report, in:

$<$ http://www.princeton.edu/avkat/reports/2008fieldworkreport.pdf $>$ : 21-26 (20/09/2015).

- 2015: "The Fortress of Çoban Kalesi, Late Medieval Ceramic and Small Finds", in Düring, B. S. and Glatz, C. (eds.), Kinetic Landscapes, The Cide Archaeological Project 2009-2011: Surveying the Western Turkish Black Sea Region, Warsaw: 345-356. 
Vryonis, S., Jr., 1971: The Decline of Medieval Hellenism in Asia Minor, and the Process of Islamization from the Eleventh through the Fifteenth Century, Publications of the Center for Medieval and Renaissance Studies 4, Berkeley, CA.

Waksman, S. Y. and Teslenko, I., 2010: "NNovy Svet Ware', an Exceptional Cargo of Glazed Wares from a $13^{\text {th }}$-Century Shipwreck near Sudak (Crimea, Ukraine)Morphological Typology and Laboratory Investigations", The International Journal of Nautical Archaeology 39/2: 357-375.

Wilson, D. R., 1960: The Historical Geography of Bithynia, Paphlagonia and Pontus in the Greek and Roman Periods: A New Survey with Particular Reference to Surface Remains Still Visible (Unpubl. Diss.; University of Oxford).

Winkelmann, F., 1985: Die byzantinische Rang- und Ämterstruktur im 8. und 9. Jahrhundert. Faktoren und Tendenzen ihrer Entwicklung, Berliner byzantinische Arbeiten 53, Berlin.

Witte, J., 2012: "Roman and Byzantine Bricks and Tiles: 1988-2004", in Lightfoot, C. S. and Ivison, E. (eds.), Amorium Reports 3: The Lower City Enclosure. Finds Reports and Technical Studies, Istanbul: 297-377.

Zelenko, S. M., 2008: Podvodnaja archeologija Kryma / Underwater Archaeology of Crimea (Kiev 2008) (in Russian with a foreword in English). 

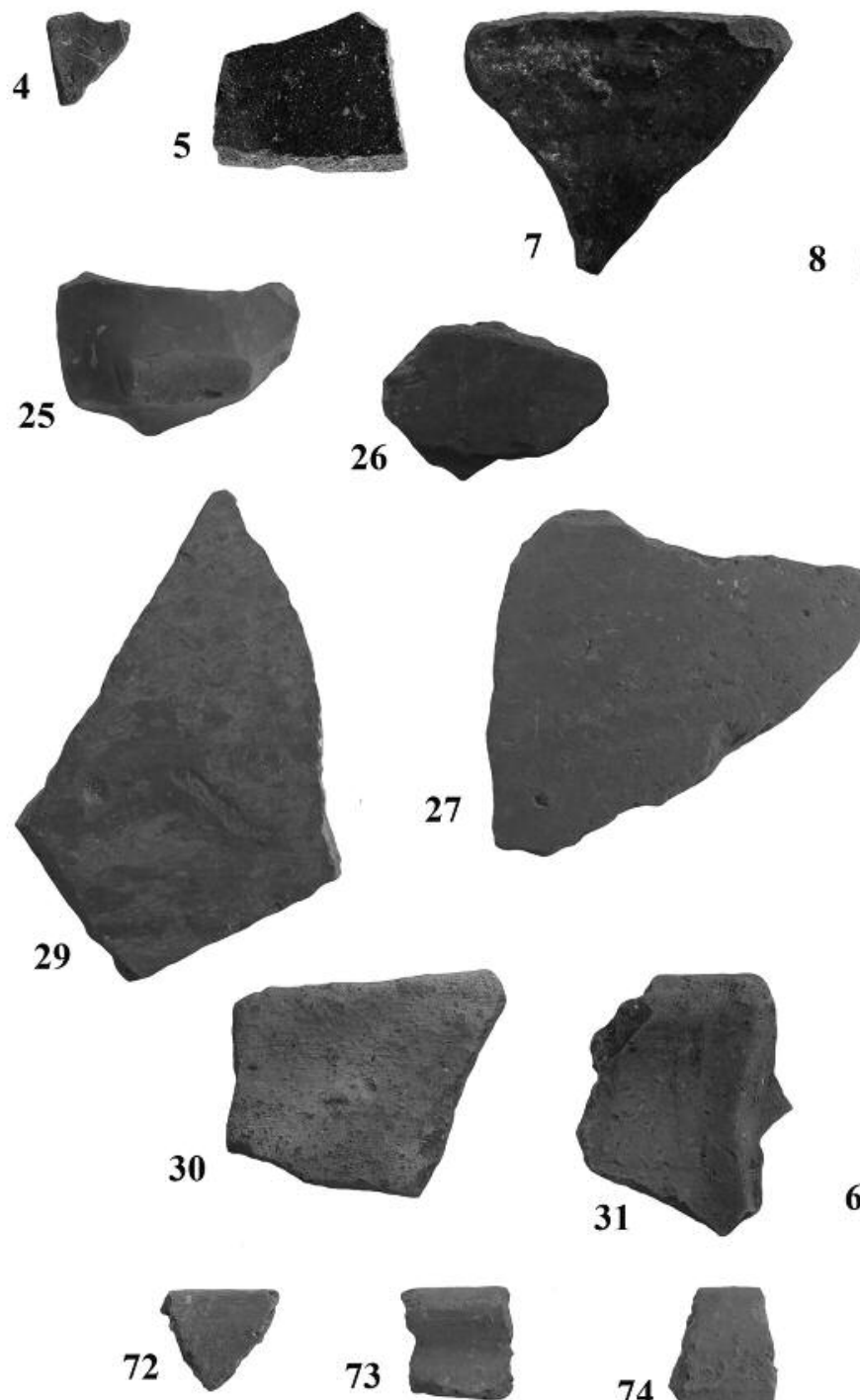

64
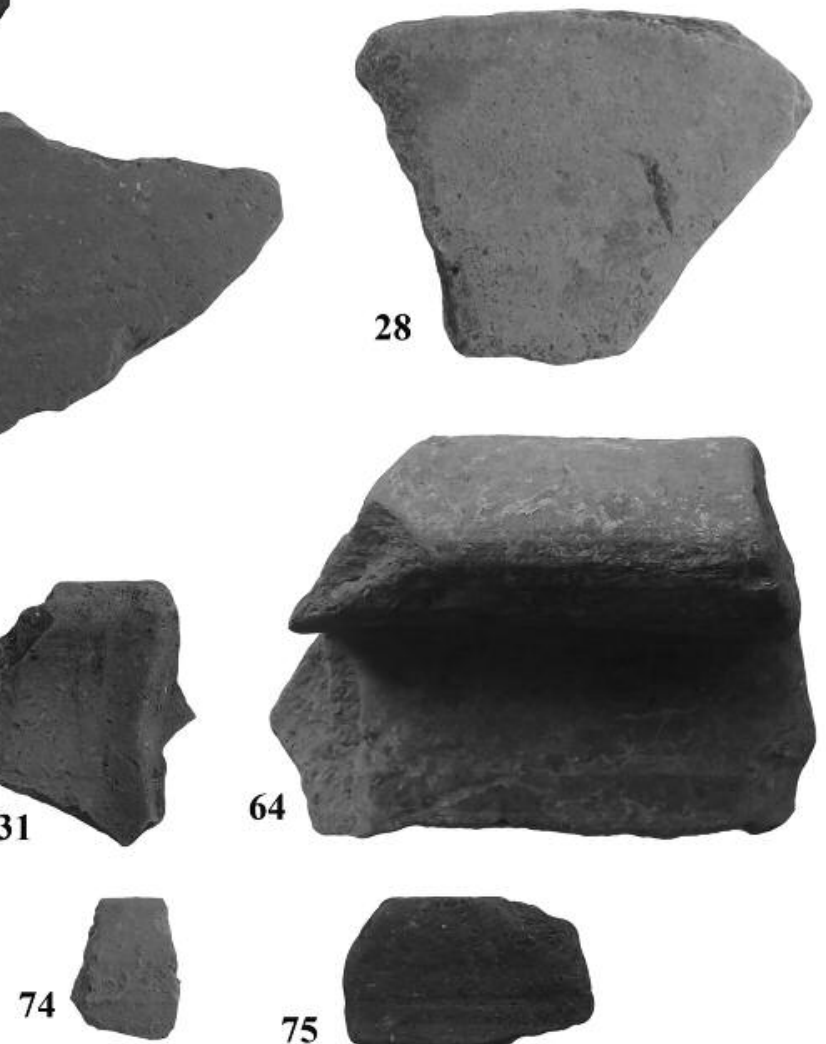

75
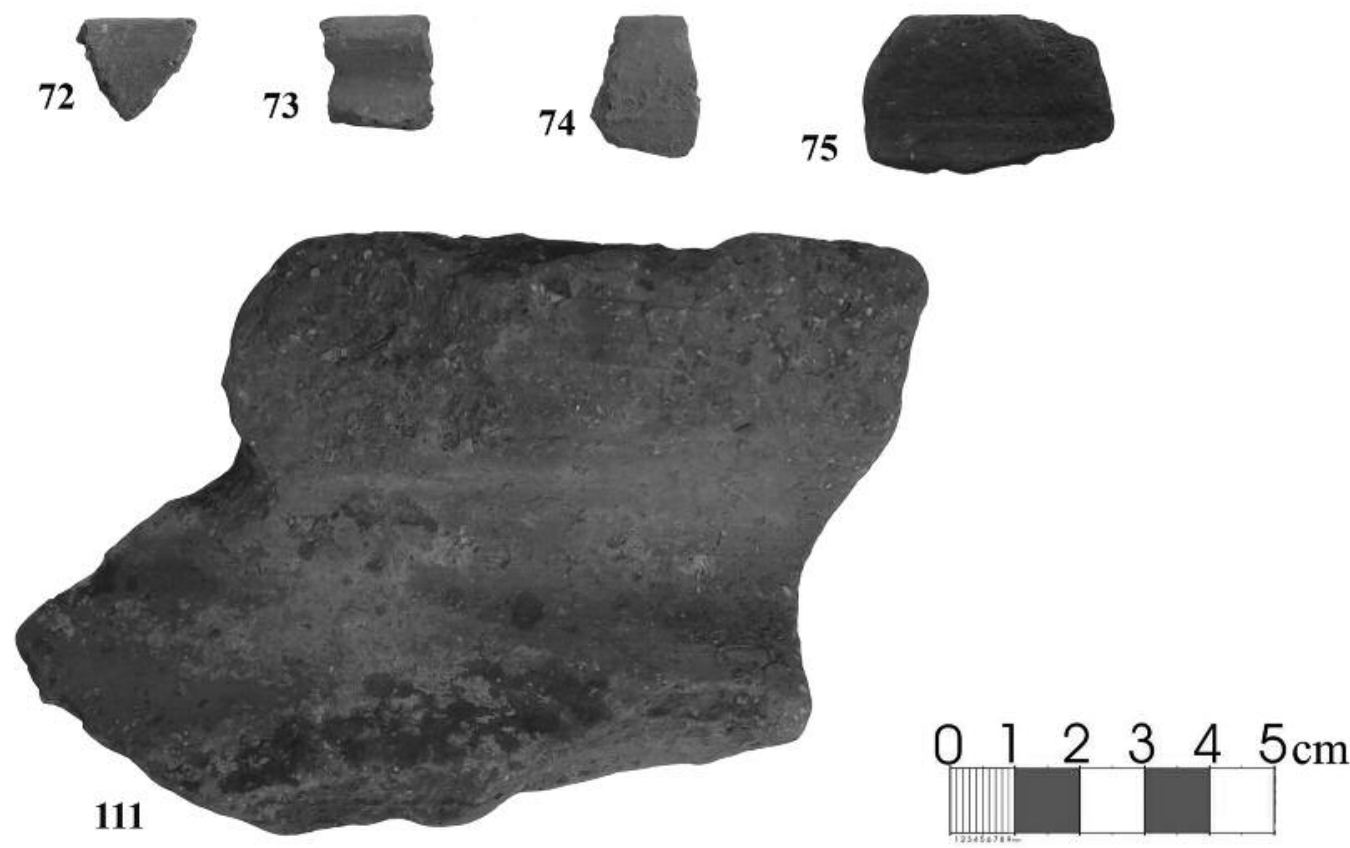

Pl. 22 : Nos 4-31 : Tableware; $n^{\text {os } 4-9: ~ G l a z e d ~ v e s s e l ~ f r a g m e n t s ; ~} n^{\circ} 25$ : A handle fragment of open forms; and $n^{\text {os }}$ 26-29: Body fragments of open forms; $n^{\text {os }} 30-31$ : Rim fragments of closed forms; $n^{\text {os }}$ 64-75: Kitchen ware; $n^{\circ}$ 64: A rim fragment of a basin/deep bowl; $n^{\text {os }}$ 72-75: Rim fragments of the closed forms; and $n^{\circ}$ 111: Storage ware, a rim fragment of pithoid vessels and pithoi. 

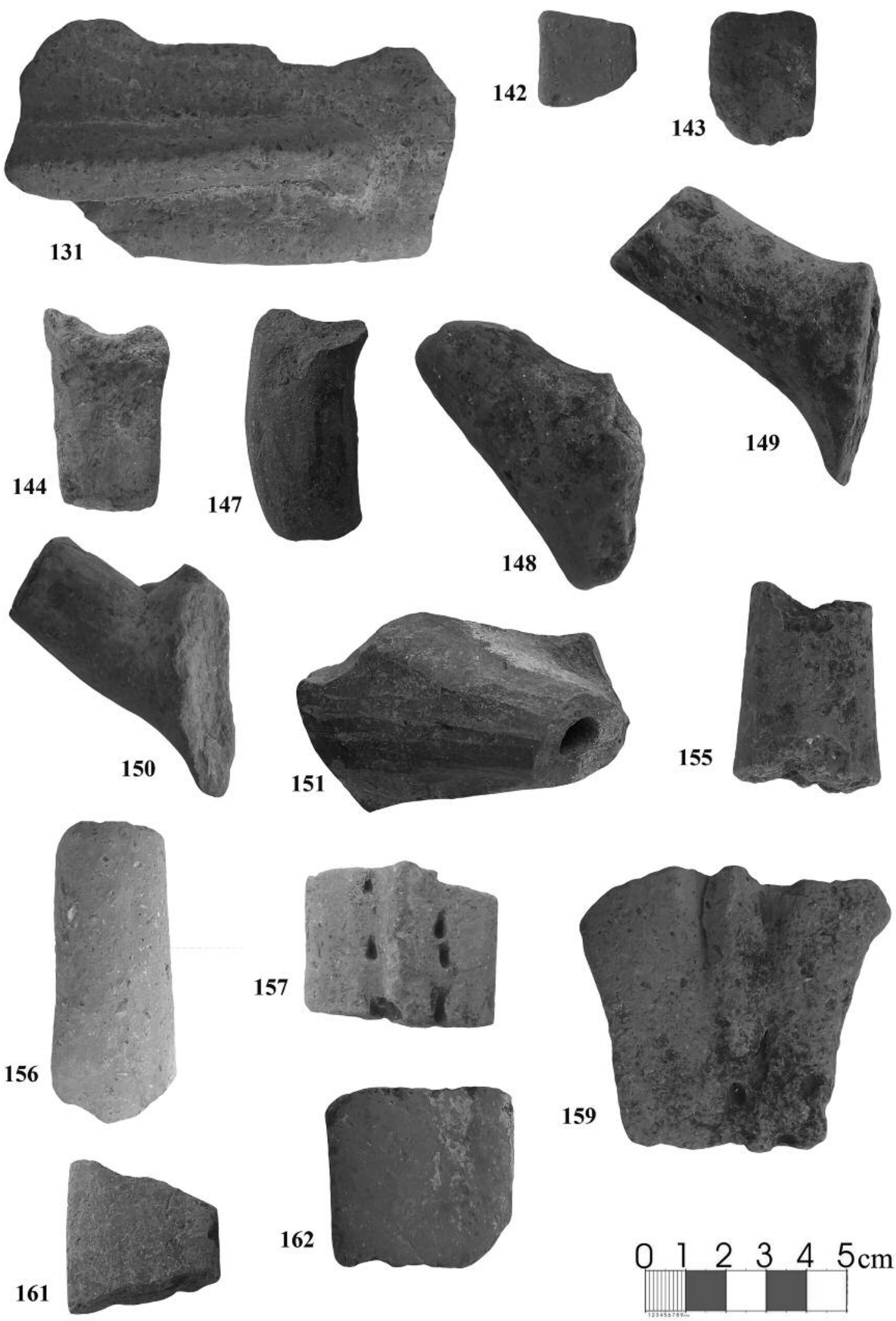

Pl. 23 : $\mathbf{N}^{\text {os }}$ 131-162 : Miscellaneous coarse vessel fragments; $n^{\circ}$ 131: A lid fragment; and $n^{\text {os }}$ 142-162: Handle fragments of undetermined closed forms. 


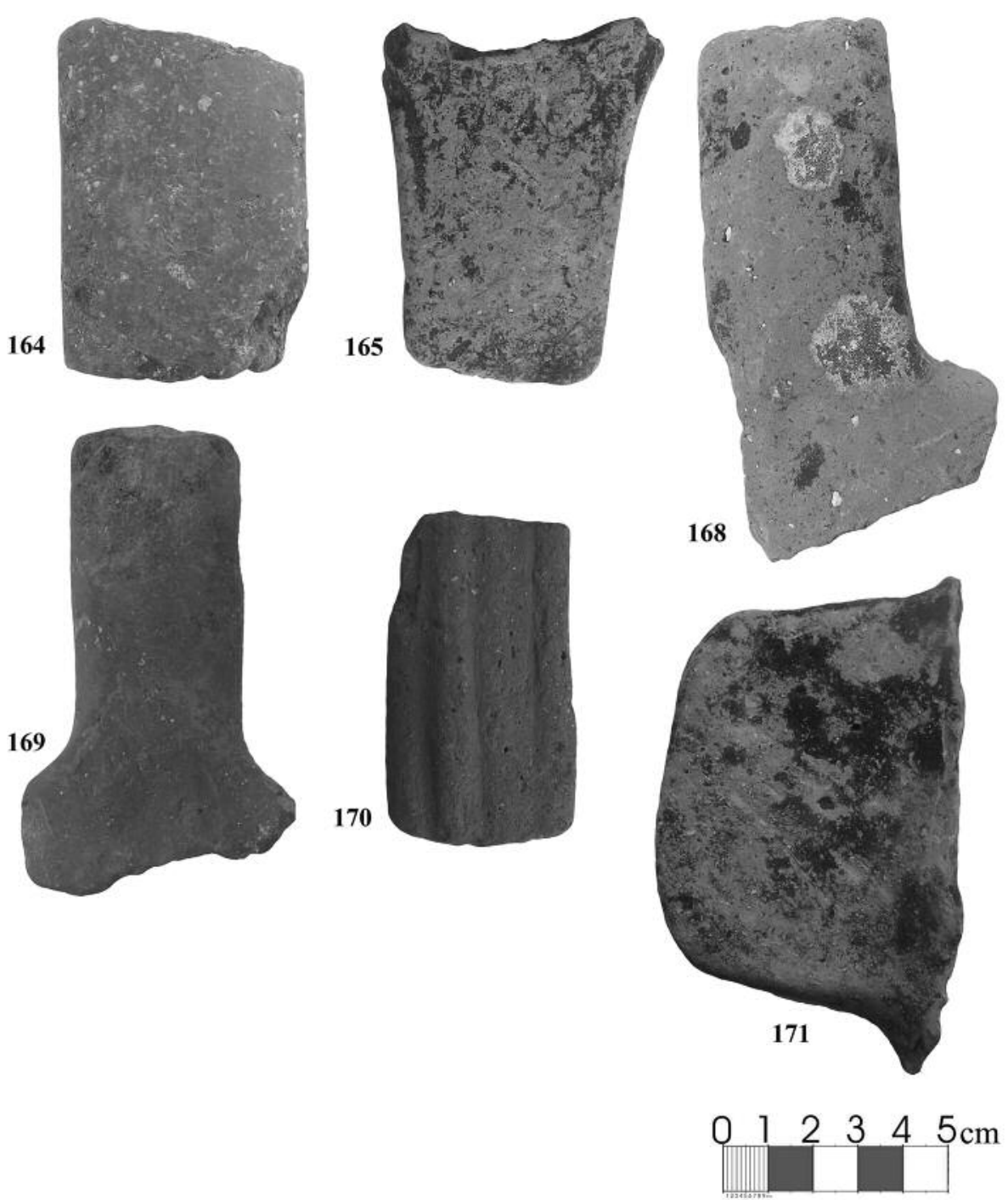

Pl. 24 : Nos 164-171 : Miscellaneous coarse vessel fragments; handle fragments of undetermined closed forms. 

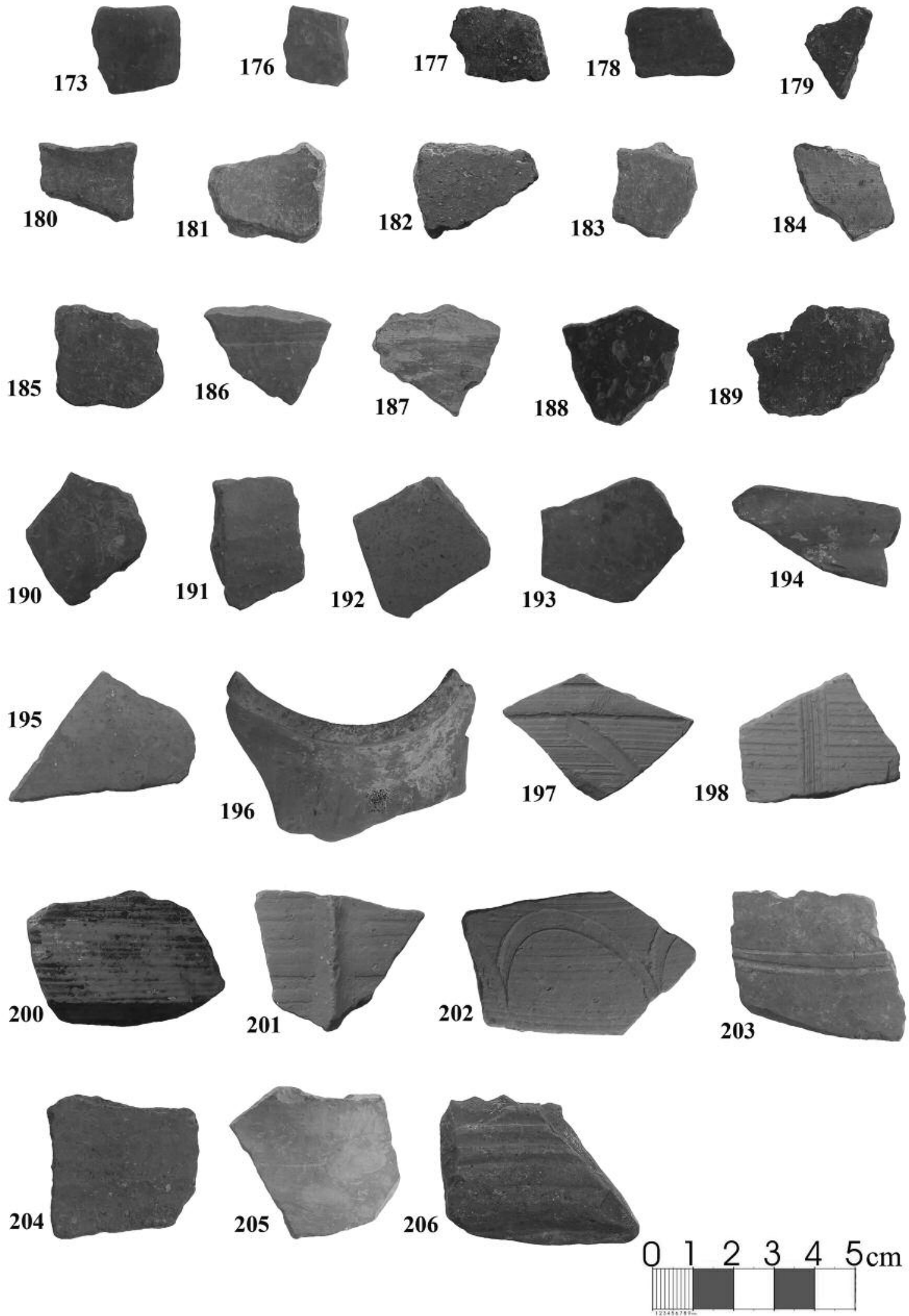

Pl. 25 : Nos 173-206 : Miscellaneous coarse vessel fragments, body fragments of undetermined closed forms. 

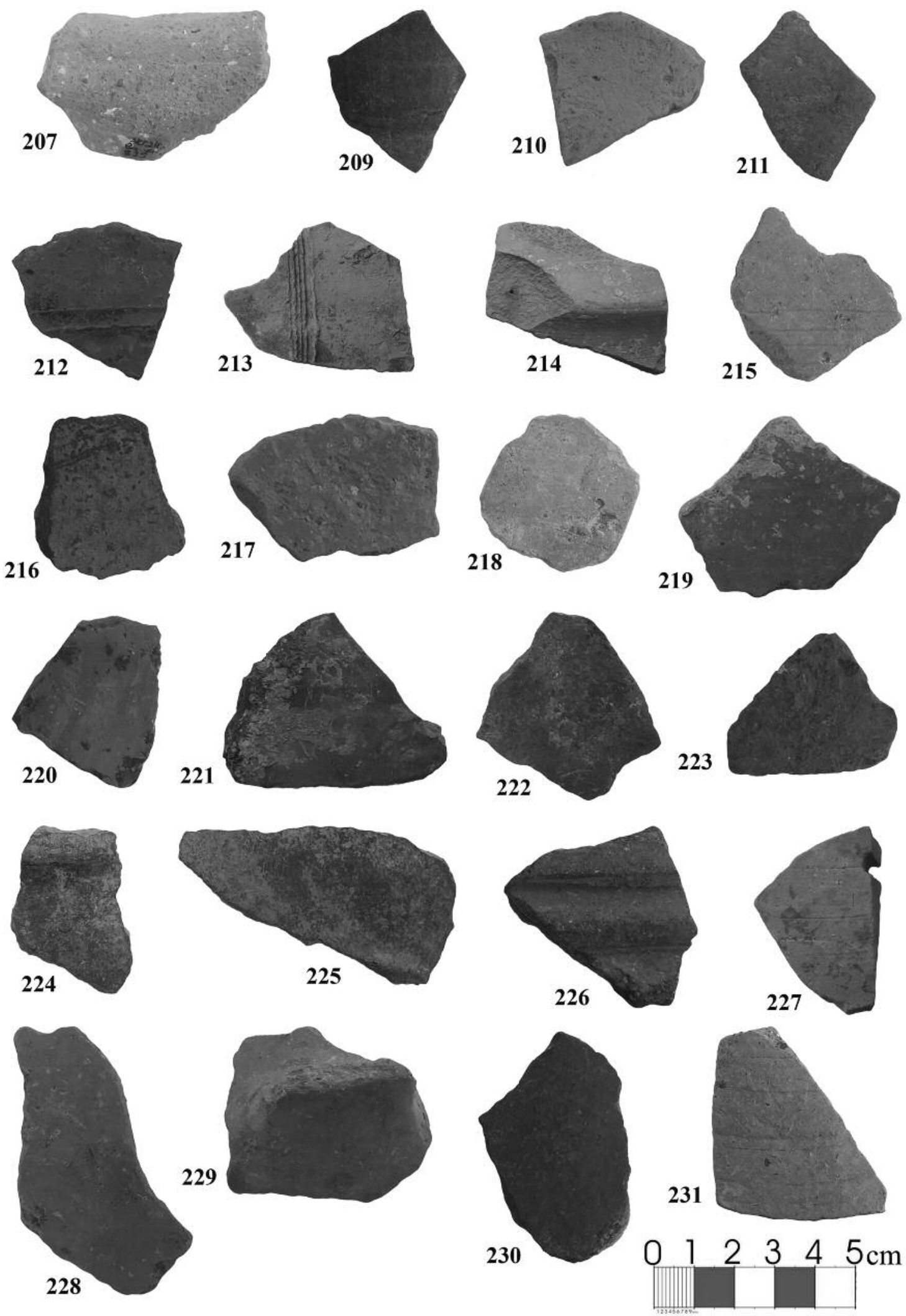

Pl. 26 : Nos 207-231 : Miscellaneous coarse vessel fragments, body fragments of undetermined closed forms. 

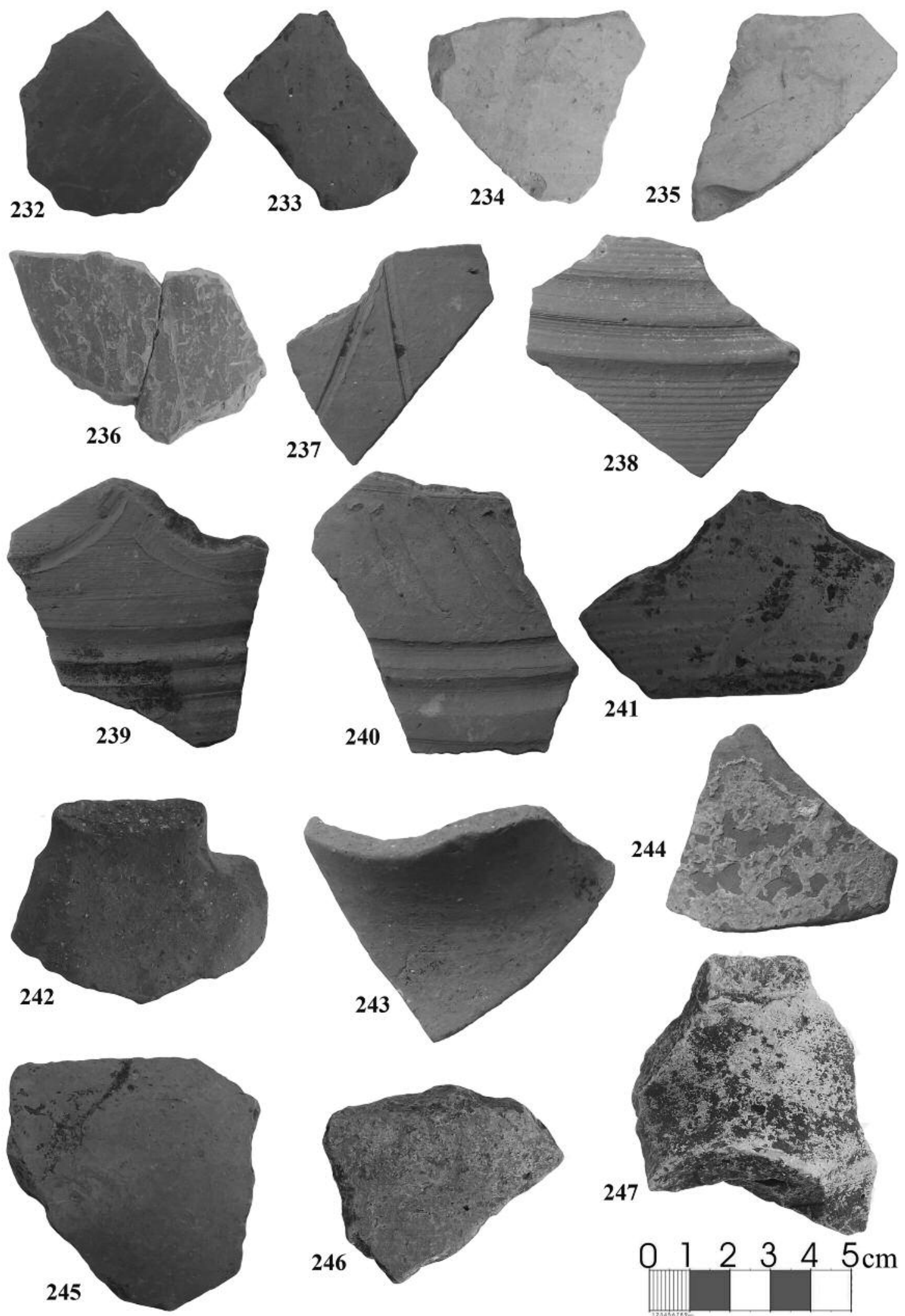

Pl. 27 : Nos 232-247 : Miscellaneous coarse vessel fragments, body fragments of undetermined closed forms. 

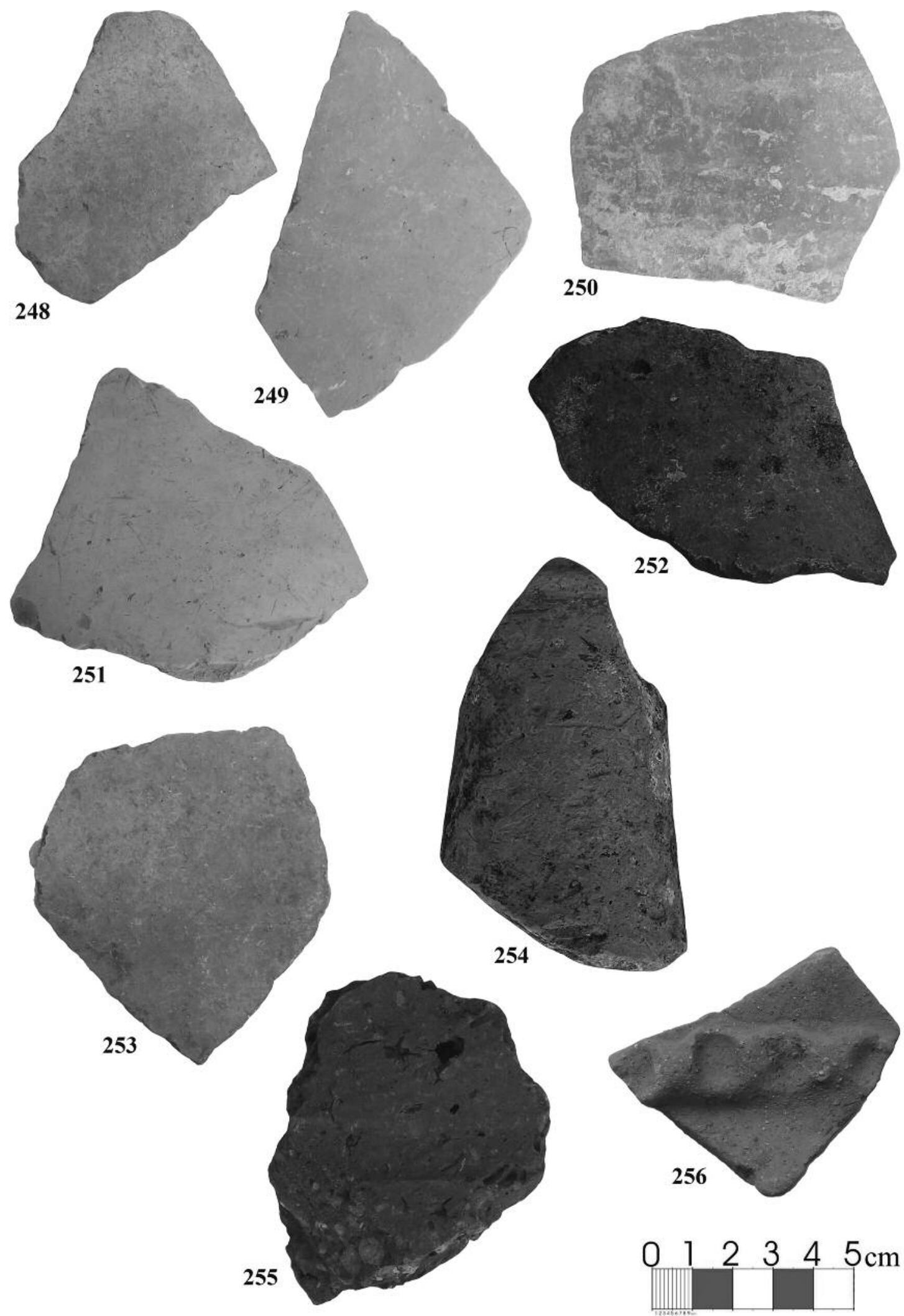

Pl. 28 : Nos 248-256 : Miscellaneous coarse vessel fragments, body fragments of undetermined closed forms. 

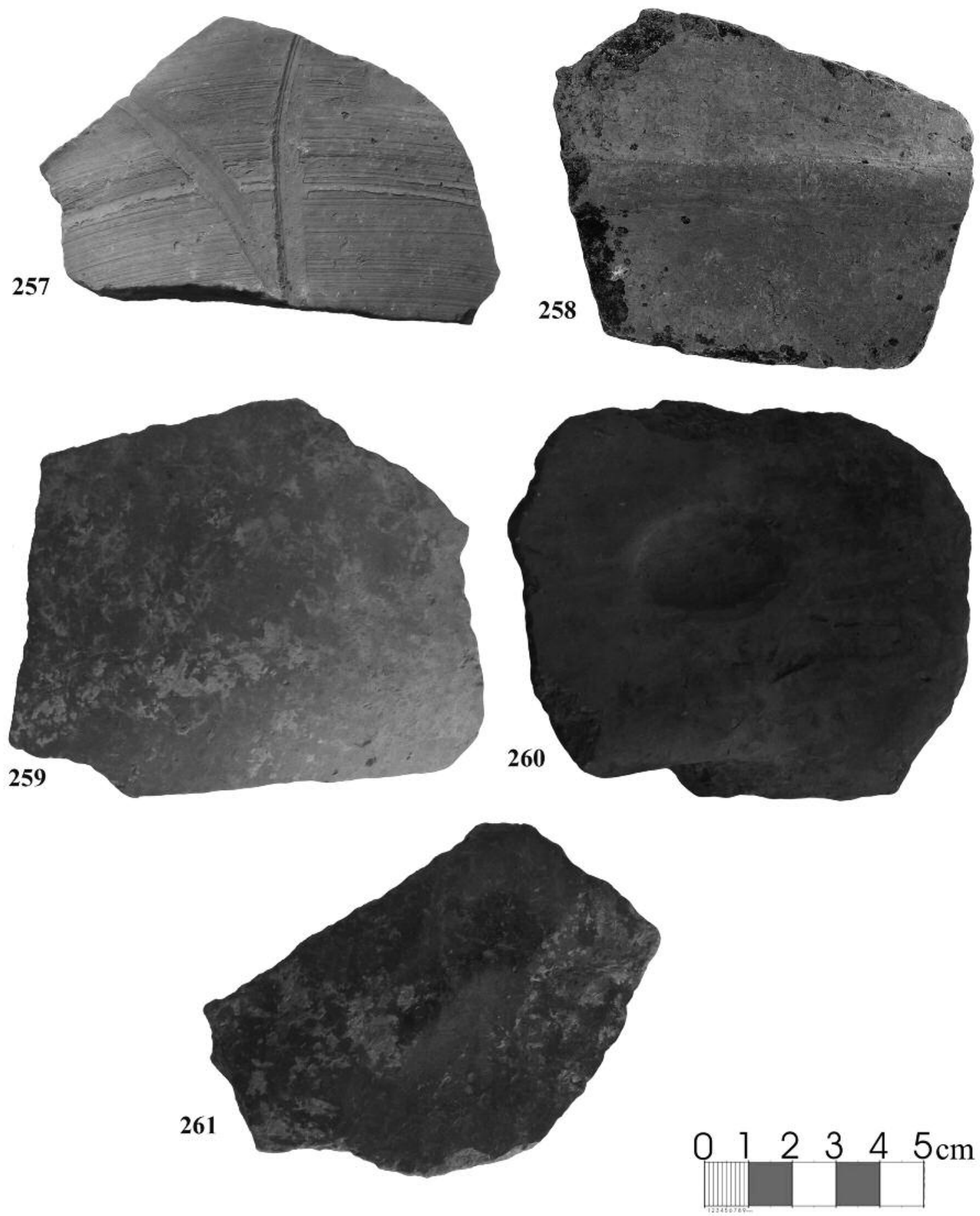

Pl. 29 : Nos 257-261 : Miscellaneous coarse vessel fragments, body fragments of undetermined closed forms. 

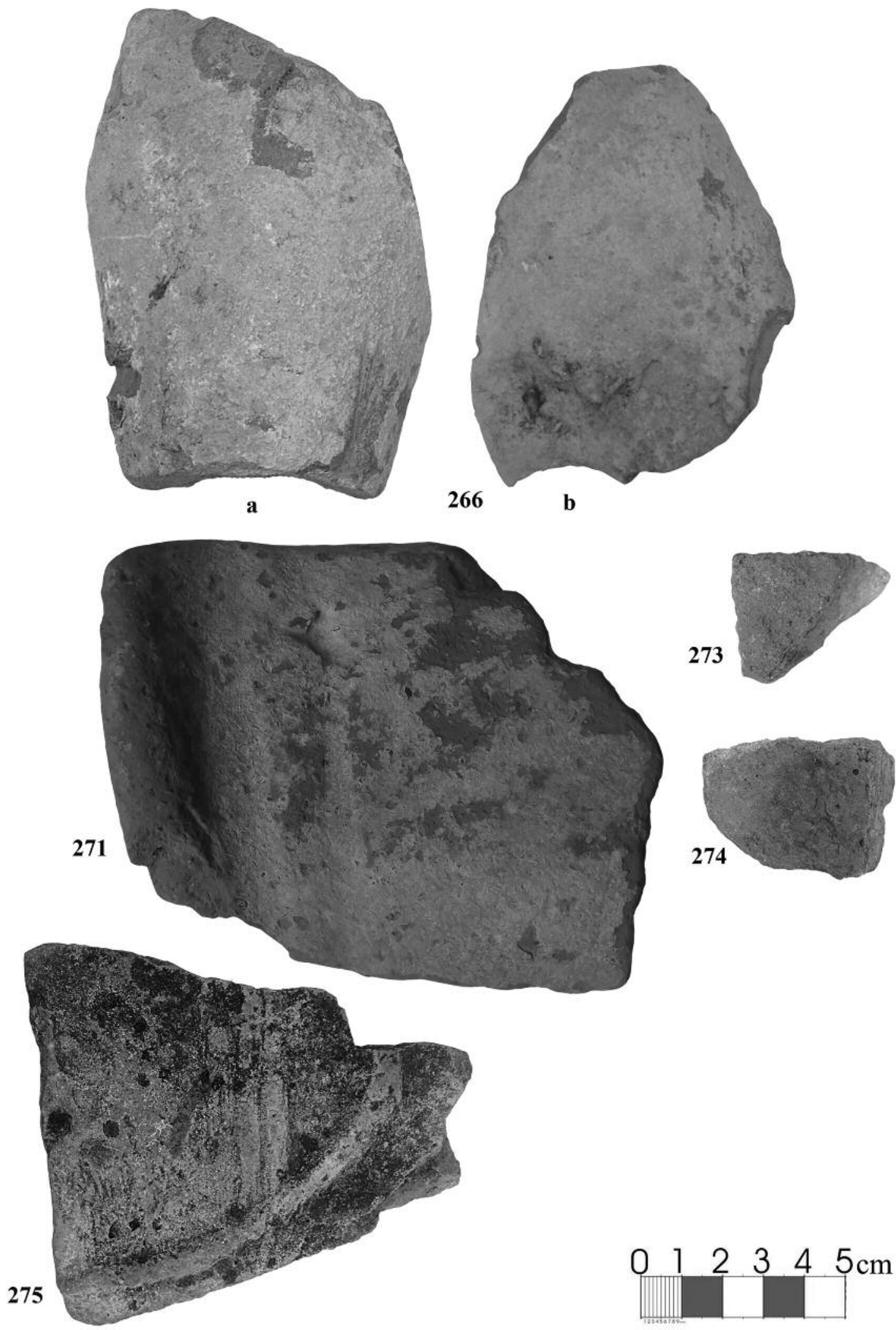

Pl. 30 : Nos 266-275 : Architectural ceramics; $n^{0} 266$ : A pipe fragment; and $n^{\text {os }}$ 271-275: Tile fragments. 


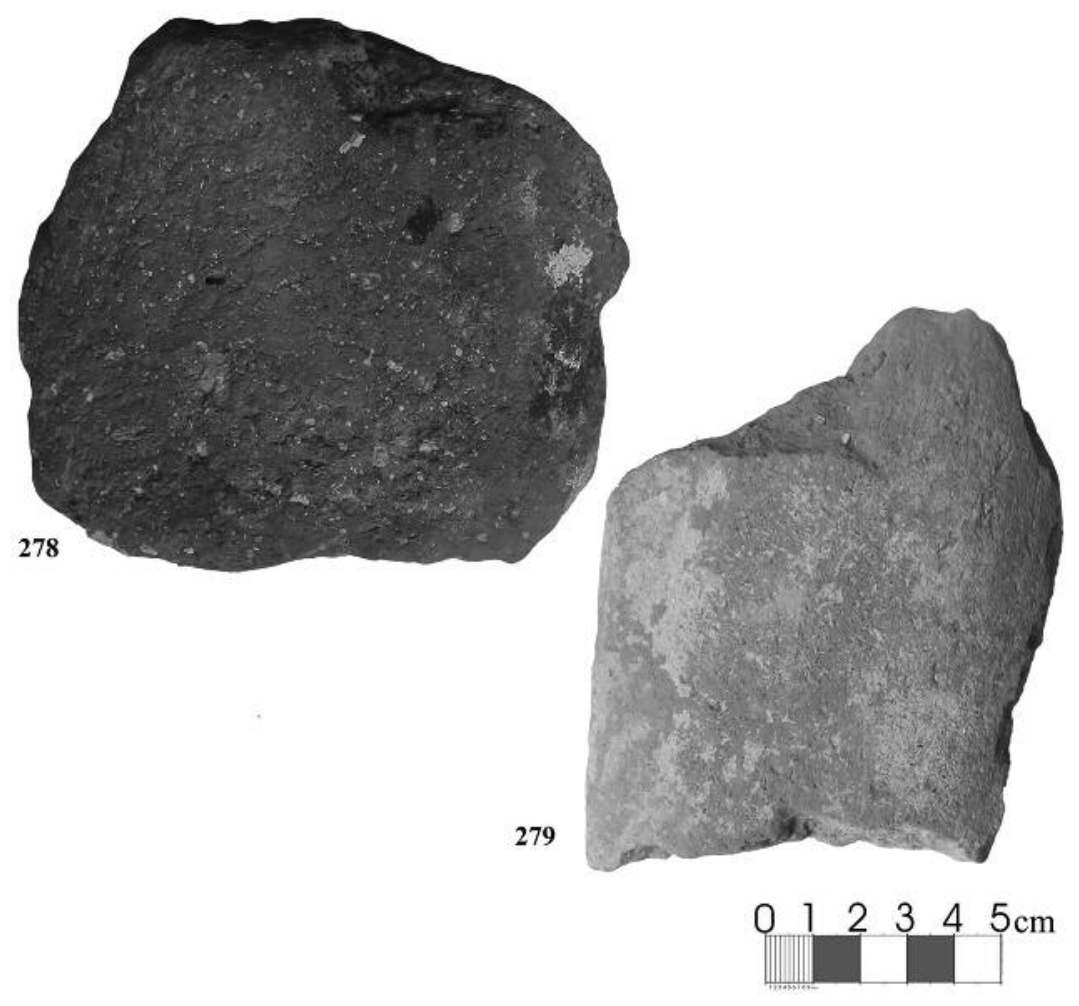

Pl. 31 : Nos 278-279 : Architectural ceramics, tile fragments. 


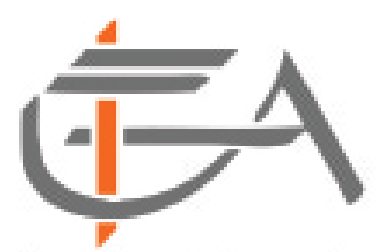

Institut Français d'Etudes Anatoliennes

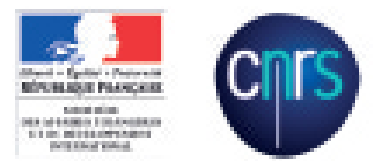

Eglise paléochrétienne de Bindéos (Pisidie), détail de la mosaïque ornant le sal de la nef centrale, $4^{e} \mathrm{~s}$. ap. J.-C. 